WSR C-RP-90-424-1

ARBoni

Revision 1, May 1991

Copy No.

Derivative Classifier

\title{
TRITIUM IN THE SAVANNAH RIVER SITE ENVIRONMENT (U)
}

C.E. Murphy, Jr.

L.R. Bauer

D.W. Hayes

W.L. Marter

C.C. Zeigler

D.E. Stephenson

D.D. Hoel

D.M. Hamby

Approved by:

A.L. Boni, Manager

Environmental Technology Section

Savannah River Laboratory

\begin{abstract}
This report was prepared as an account of work sponsored by an agency of the United States Government. Neither the United States Government nor any agency thereof, nor any of their employees, makes any warranty, express or implied, or assumes any legal liability or responsibility for the accuracy, completeness, or usefulness of any information, apparatus, product, or process disclosed, or represents that its use would i:ot infringe privately owned rights. Reference herein to any specific commercial product, process, or service by trade name, trademark, manufacturer, or otherwise does not necessarily constitute or imply its endorsement, recommendation, or favoring by the United States Government or any agency thereof. The views and opinions of authors expressed herein do not necessarily state or reflect those of the United States Government or any agency thereof.
\end{abstract}

\section{DISCLAIMER}

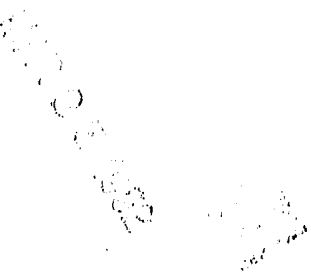

\author{
Westinghouse Savannah River Company \\ Savannah River Site \\ Aiken, SC 29808
}
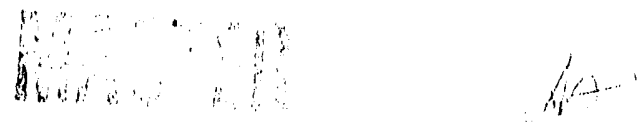


\section{TABLE OF CONTENTS}

EXECUTIVE SUMMARY

ABSTRACT

INTRODUCTION

CHAPTER 1 TRITIUM RELEASES TO THE ENVIRONMENT

Introduction

Reactor Facillties .................................................................................... 3

Separations Facilities ............................................................................ 10

Other Areas ..................................................................................................... 14

Inadvertent Tritlum Releases .................................................................... 15

Summary of SRS Tritium Releases ....................................................... 16

Comparison of SRS Releases to Other Sources ................................. 17

CHAPTER 2 TRITIUM CONCENTRATIONS AND TRANSPORT AT SRS

Environmental Tritlum from Atmospheric Releases ........................... 19

Tritium Concentrations from Inadvertent Releases to the Atmosphere ................................................................................................. 35

SRS Surface Water Tritium Releases and Transport .......................... 43

Impact of SRS on Tritium in Groundwater ......................................... 72

Tritium Transport from SRS to the Environment ................................. 94

CHAPTER 3 ASSESSMENT OF DOSE/RISK FROM SRS TRITIUM RELEASES Relationship of Dose to Risk and Health Effects ................................ 103

EPA Risk Estimates for LOW-LET Radiation ..................................... 103

Tritium Exposure and Dose to Man ....................................................... 105

Tritium Transport and Dose Models .................................................... 107

Verification of Models Using Monitoring Data .................................. 111

Impact of SRS Tritium Releases on the Offsite Population ............... 112

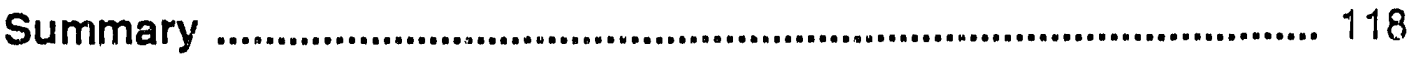


CHAPTER 4 SRS RELEASES COMPARED TO OTHER SOURCES OF ENVIRONMENTAL RADIATION

Introduction

Natural Sources 119

Man-Made Sources 120

Radiation Levels in the Vicinity of the SRS 121

SRS Study of Terrestrial Dose Rates 123

Comparisons of Tritium Concentrations and Doses on and Near the SRS with Applicable Regulations 123

Radiation Protection Guidelines ................................................................. 126

REFERENCES 129

APPENDIX 1 ENVIRONMENTAL MONITORING OF CONCENTRATIONS AND RELEASES

Introduction A.1

Atmospheric Effluent Monitoring A.1

Tritium Facilities A.2

Tritium Monitoring in Aquatic Media A.3

Atmospheric Environmental Monitoring A.7

Monitoring of Tritium in Biota A.7

Monitoring Tritium in Food A.7

Tritium Monitoring in Groundwater at SRS A.8

Comparison of SRS Monitoring Data with SCDHEC and GDNR A.9

Tritium Emergency Response Program A.12

APPENDIX 2 BIBLIOGRAPHY A. 15

SRS Environmental Monitoring and Related Reports A.15

SRS Tritium Reports and Papers of Environmental Interest A.25 APPENDIX 3 PHYSICAL AND CHEMICAL CHARACTERISTICS OF TRITIUM 


\section{LIST OF FIGURES}

1.1 Map of the Savannah River Site. .............................................................. 4

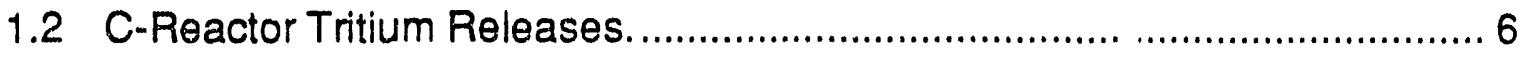

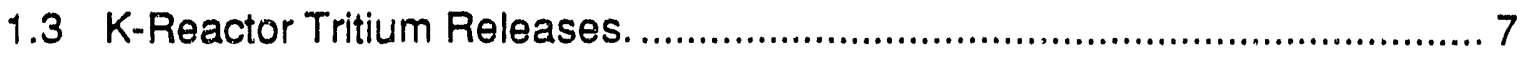

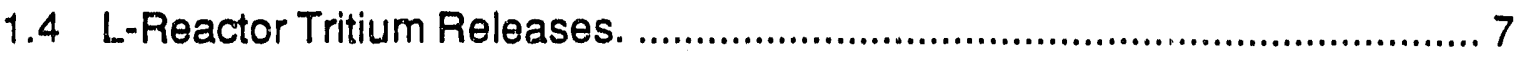

1.5 Tritium Releases to the L-Area Oil and Chemical Basin. ......................... 8

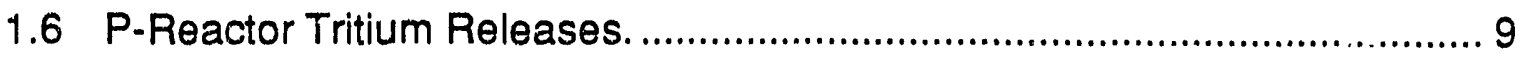

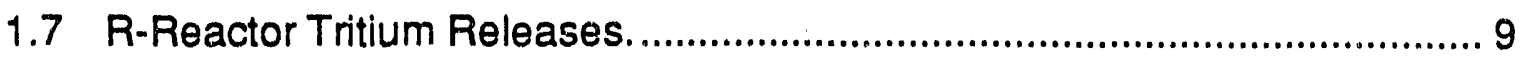

1.8 Annual Tritium Input into the $F$ and $H$ Seepage Basins and the Total Migration to Streams. .................................................................... 11

1.9 Atmospheric Releases of Tritium from the $\mathrm{F}$ and $\mathrm{H}$ Area Tritium Facilities.

1.10 HT and HTO as a Percentage of Total Releases from the Tritium Separations Facilities 1976 - 1979.

$1.11 \mathrm{HT}$ and HTO as a Percentage of Total Releases from the Tritium Facilities 1985 - 1988.

1.12 Total Liquid Releases of Tritium Directly to Streams from the Separations Areas, Including RBOF.

1.13 Inadvertent Tritium Releases from SRS Facilities Showing Type of Release and Chemical Form of Tritium.

1.14 Tritium Released by SRS Operations and the Amount of that Tritium Remaining in 1988 After Radioactive Decay.

1.15 A Comparison of Environmental Tritium Inventory Due to SRS Releases and Releases from Other Sources of Tritium.

2.1 The Directional Distribution of Tritiated Water Vapor in the Vicinity of SRS (1982 - 1986 Data).

2.2 The Decrease in Average (1982-1986) and Maximum (All Available Data) Air Tritiated Water Concentration with Distance from the Center of SRS.

2.3 The Year-to-Year Variation in Slope and the Characteristic Concentration of Air Water Vapor Tritium at $20 \mathrm{~km}$.

2.4 The Effect of Releases on the Concentration of Tritiated Air Water Vapor.

2.5 Variation of Average (1982-1986) and Maximum (All Available Data) Tritium Concentrations in Rainwater with Distance from the Center of SRS. 
2.6 The Annual Average Concentration of Tritium in Rainwater Compared to the Concentration in the Air at Each Monitoring Location (1982-1986). 24

2.7 The Distribution of Tritium in Rainwater Around SRS (1982 - 1986). ..... 24

2.8 A Comparison of the Concentration of Tritium in Air and Rainwater in Different Directions from the Center of SRS. ......................................... 25

2.9 The Major Paths of Tritium Transport in the Soil. .................................... 26

2.10 Soil Water Tritium Concentrations at Various Distances from the Center of SRS.

2.11 Tritiated Water Depth Profiles from Two Locations at the Same Distance from the Center of SRS but with Different Exposure Histories. 27

2.12 The Spatial Distribution of Tritiated Water in Vegetation in the Vicinity of SRS.

2.13 A Comparison of the Air Water Vapor and Vegetation Tritium Concentration at $20 \mathrm{~km}$ for Sampling Transects at Various Directions from the Center of SRS (1982 - 1986).

2.14 The Decrease in Tritiated Water Concentration with Distance from the Center of SRS for Annual Averages (1982-1986) and Maximums (All Available Data).

2.15 The Variation in the Ratio of Vegetation Tritiated Water Concentration to Tritiated Atmospheric Moisture Compared to the Tritium Form and Amount in Inadvertent Releases.

2.16 The Decrease in the Tritium Concentration of Wood Organic Material with Distance from the Center of SRS.

2.17 The Frequency of Deer Within a Given Range of Tritiated Water Concentration Collected During the Intensive Study in 1966 and During Routine Monitoring in 1986-1987.

2.18 The Ratio of Organic Tritium to Tritiated Water in Individual Organs for Deer Collected During 1966 Hunting Season.

2.19 The Annual Average Tritium Concentration in Milk Water for Each Dairy or Distributor.

2.20 Tritium Concentration in the Water of Selected Vegetable Food Grown in the Vicinity of SRS.

2.21 The Tritiated Water Concentration of Animal Foods Collected in the Vicinity of SRS Compared to the Annual Average Tritium

Concentration of Air Moisture.

2.22 The Maximum Tritiated Water Content of Vegetation Leaves Collected at Approximately $40 \mathrm{~km}$ from the Source of the Release Compared to Estimates Calculated from Exposure to Tritiated Water Vapor for Each Release. 
2.23 The Characteristic Release Curves for Tritiated Water in Vegetation

Following Exposure to Atmospheric Tritiated Water Vapor and

Tritiated Hydrogen.

2.24 Total Tritium in Streams From Direct Release and Seepage

Through Groundwater.

2.25 Percentage of Tritium in Streams from Direct Release and Seepage

Through Groundwater. 45

2.26 Stream Locations Monitored for Tritium Concentration 46

2.27 A Comparison of Total Tritium Measured in SRS Creeks and the Tritium Measured in the Savannah River at Highway 301

Downstream from SRS.

2.28 Total Releases to SRS Streams by Either Direct Release to the Stream or Seepage from the Groundwater.

2.29 Tritium Releases from P-and R-Reactor Areas. 51

2.30 Tritium Releases from Par Pond to Lower Three Runs Creek. 52

2.31 Tritium Concentrations in Lower Three Runs Creek at Patterson's Mill. 52

2.32. P- and L- Reactor Area Releases to Steel Creek. 53

2.33 Tritium Concentration Measured in Steel Creek. 55

2.34 K-Reactor Area Releases to Pen Branch. 55

2.35 Tritium Concentrations in Pen Branch. 56

$2.36 \mathrm{~F}-, \mathrm{H}-$, and C- Area Releases to Four Mile Creek. 57

2.37 Tritium Concentrations Measured in Four Mile Creek. 57

2.38 Tritium Releases from 400-D Area. 58

2.39 Tritium Concentrations in Beaver Dam Creek. 59

2.40 Dispersion of Tritium in the Savannah River Following a Release Through Beaver Dam Creek. 60

2.41 Tritium Concentrations Measured in Upper Three Runs Creek Compared to Atmospheric Releases from SRS Facilities. 61

2.42 Tritium Concentrations in the Savannah River Above SRS 62

2.43 Tritium Concentrations in the Savannah River Below SRS. 63

2.44 Measured Versus Calculated Tritium Concentrations in the Savannah River Below SRS. 
2.45 Comparison of Measured Versus Projected Tritium Concentrations in the Savannah River Below SRS.

2.46 Location of Downriver Water Treatment Plants....................................... 65

2.47 Tritium Concentrations at the Beaufort/Jasper Water Treatment Plant. .. 66

2.48. Tritium Concentrations at the Port Wentworth Water Treatment Plant. .... 67

2.49. Tritium Concentrations at Highway 301 and the Downriver

Water Treatment Plants.

2.50. Tritium Concentrations in the Savannah River Estuary...........................6.68

2.51. Tritium - Salinity Relationship in the Savannah River Estuary................... 69

2.52. Tritium Concentrations in Coastal Waters Around the Mouth of the Savannah River. 70

2.53. Tritium - Salinity Relationship in Coastal Waters....................................... 71

2.54. Tritium Concentrations in Par Pond Water and Fish. .............................. 73

2.55 Geologic Cross-Section Showing the Main Aquifers. .............................. 74

2.56 Location of F-and H-Area Seepage Basins on the High Ground Between Upper Three Runs and Four Mile Creeks.

2.57 Vertical Distribution of Tritium in Groundwater under F-Area Seepage Basin Number 3

2.58 Horizontal Spread of Tritium Plume Downgradient from F-Area Seepage Basin Number 3 78

2.59 Placement of Wells Around the F-Area Seepage Basins. ....................... 79

2.60 Locations of H-Area Seepage Basin Wells. ............................................ 80

2.61 Tritium Plumes from H-Area Seepage Basins......................................... 82

2.62 Tritium Zones in Groundwater at the Burial Ground. .............................. 83

2.63 Schematic of Grid Wells in the Low-Level Waste Burial Ground.............. 84

2.64 Tritium from Spent Melt Test in Groundwater in October 1970 ............... 87

2.65 Time for Water and Tritium to Travel 643-G Burial Ground Flow Paths. .. 88

2.66 K-Area Showing Locations of the Reactor Seepage and Containment Basins and the Monitoring Wells Around Each Basin. .............................. 89

2.67 Cross Section of the L-Area Oil and Chemical Basin Based on Preconstruction Data. 
2.68 L-Area Showing the Locations of the Reactor Seepage and Oil and Chemical Basins with the Monitoring Wells at Each Basin.

2.69 C-Area Showing the Location of the Reactor Seepage Basins and the Associated Monitoring Wells.

2.70 P-Area Showing the Locations of the Reactor Seepage Basins and Monitoring Wells.

2.71 The Transport of Tritium at the Savannah River Site During the Period 1952 to 1988.

2.72 The Cycling of Tritium (in Curies) Released to the Atmosphere at SRS from 1952 to 1988 . 98

2.73 The Global Distribution of SRS Tritium Releases According to the NCRP Seven-Compartment Model 100

3.1 Dose-Response Relationship for Stochastic Effects. 103

3.2 Simplified Pathways Between Radioactive Materials Released to the Atmosphere and Man.

3.3 Simplified Pathways Between Radioactive Materials Released to Groundwater or Surface Waters and Man.

4.1 The Percentage Contributions to Radiation Exposure for the Population in the SRS Vicinity. 


\section{LIST OF TABLES}

1.1 Sources of Tritium from SRS Activities, Curies. ................................... 17

2.1 A Comparison of Tritlum in the Soil and Forest Floor with the Tritium in Atmospheric Moisture and Rainwater. ............................................... 28

2.2 Tritium Release Characteristics. ......................................................... 41

2.3 Maximum Environmental Concentrations Following Tritium Releases,

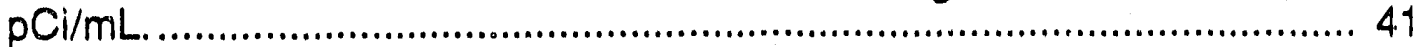

2.4 Comparison of Characteristics of HTO and HT Releases. ..................... 42

2.5 Liquid Tritium Releases (1954-1988). .................................................. 43

2.6 Tritium Inventory in SRS Streams and the Savannah River. ................... 49

2.7 Tritium Concentrations in SRS Streams and the Savannah River (1954-1988) ............................................................................... 50

2.8 Tritium Activity in F-Area Seepage Basin Wells. .................................... 78

2.9 Tritium Activity in H-Area Seepage Basin Wells. ..................................... 81

2.10 Estimates of Tritium in Groundwater Beneath 643-G. ........................... 85

2.11 Annual Average Concentrations of Tritium in 643-7G and 643-28G Grid Wells.

2.12 Tritium Concentrations in K-Area Seepage Basin Monitoring Wells $(\mathrm{pCi} / \mathrm{ml})$.

2.13 Tritium Concentrations in K-Area Contaminant Basin Monitoring Wells $(\mathrm{pCi} / \mathrm{mL})$ 90

2.14 L-Area Monitoring Well Average Tritium Concentrations for 1988 $(\mathrm{pCi} / \mathrm{mL})$ 90

2.15 Tritium Concentrations in C-Area Seepage Basin Wells ( $\mathrm{pCi} / \mathrm{mL})$........... 94

2.16 Tritium Concentrations in P-Area Seepage Basin Wells ( $\mathrm{pCl} / \mathrm{mL}$ ) .......... 95

2.17 Deposition Velocities $(\mathrm{cm} / \mathrm{s})$.................................................................. 97

2.18 Components of the Hydrologic Cycle at SRS ......................................... 97

2.19 Deposition of Tritium Within $100 \mathrm{Km}$ of SRS ......................................... 99

2.20 Redistribution of Tritium in the Hydrologic Cycle in the Vicinity of SRS 99

3.1 Summary of Low-LET Radiation Risk Factors..................................... 105

3.2 Site- and Age-Specific Parameters for Atmospheric Releases. ............. 110 
3.3 Site- and Age-Specific Parameters for Liquid Releases.

3.4 Site- and Age-Specific Parameters for Liquid Releases .

3.5 Comparison of Calculated and Measured Concentrations of Tritium at the Site Boundary.

3.6. Atmospheric Tritium Releases and Offsite Doses (1954 - 1988). 115

3.7 Liquid Tritium Releases and Offsite Doses (1954 - 1988). 117

4.1 Major Sources of Radiation E:iposure in the Vicinity of SRS. 122

4.2 Potential Fatal Cancers from the Radiation Environment $80-\mathrm{km}$ Radius and Downstream River Water Consumers Year 2000 Population Projections.

4.3 Ratios of Average Atmospheric Tritium (HTO) Concentrations on and Near the SRS $\left(\mathrm{pCi} / \mathrm{m}^{3}\right)$.

4.4 Maximum Tritium Concentrations in Selected SRS Wells ( $\mathrm{pCl} / \mathrm{mL})$, ........ 125

4.5 Tritium Concentrations in Offsite Surface and Potable Waters. 126 
Many operations at the Savannah River Site (SRS) produce tritium. Operations that produce and handle radionuclides at the SRS result in the release of some tritlum to the environment.

Tritium is released from reactor operations, recovery of transuranic elements, recovery of tritium, laboratory research, and heavy water rework. The released tritium goes to the atmosphere, site streams, and the ground. Most of the tritium has been released due to routine operations. A small portion of the total release was from inadvertent (unplanned) releases.

Tritium has been released to the atmosphere in water vapor and other gaseous forms. It was released via stacks and via evaporation from seepage and retention basins. Of the more than 24 million curies ( $\mathrm{Ci}$ ) released to the atmosphere, $27.8 \%$ came from the reactor areas, $72.8 \%$ from the separations areas, and $0.5 \%$ from other facilities.

Tritiated water was released to streams through liquid effluents and through seepage basin and burial ground releases that entered shallow groundwater aquifers and outcropped into streams. Of the 1.5 million $\mathrm{Cl}$ of tritium released to streams, $75.1 \%$ came from the reactor areas, $15.3 \%$ from the separations areas, and $9.6 \%$ from other facilities.

The SRS facilities began operations in 1954. Many of the tritium releases occurred during the early years of operation. Of the total of about 24 million $\mathrm{Ci}$ released to the atmosphere and streams over the years of operation, about 13 million $\mathrm{Ci}$ have decayed, leaving a residual 11 million $\mathrm{Ci}$ distributed in the world environment (at the end of 1988). In addition, about 7 million $\mathrm{Ci}$ were placed into the ground in the seepage basins and burial ground. About 3.2 million $\mathrm{Cl}$ of that inventory remain.

Tritium transport through the atmosphere is governed by the processes of advection, turbulent diffusion, and deposition. Advection is the movement of gases and particulates in air with the bulk movement of the air. Diffusion is the transport which takes place through the action of eddy currents. This causes mixing and depends on the wind speed, the effects of local heating of the air, and the roughness of the earth's surface. Deposition is the sum of the processes which remove gases and particulates from the air and deposit them on the surface of the earth.

Measurements of the tritium content of the atmospheric water vapor have been made since the early 1960s. These results are reported herein for 1963 through 1988 and are shown to be related to the magnitude of the releases, the meteorological conditions, and the distance from the release point. As expected from theoretical considerations, when plotted on logarithmic coordinates, there is an approximately straight-line relationship between distance from the center of the SRS and the tritium concentrations in air.

One removal mechanism for tritium from air is deposition in rainfall. Rainfall has been collected and analyzed for tritium at most of the same locations as the air monitoring samples. The concentration of tritium in rainwater is closely related to the concentration of tritium in air.

The tritium content of soil results from the interaction of a number of processes. These include transport from liquid releases (seepage basins), rainout of tritiated water vapor, and deposition of tritiated water vapor and tritiated hydrogen gas. Upon reaching the soil, these all became part of the soll moisture. Tritium 
concentrations in soil are not routinely measured because these concentrations are represented by vegetation monitoring. Special studies show that soll tritium concentrations decrease with distance from the site center. Concentrations with depth vary based on exposure history at each point.

The tritium in vegetation is associated with the moisture in the vegetation and with the organic constituents of the dry material. The concentration is the result of a number of processes by which tritiated water enters or leaves the vegetation. These processes are controlled by tritium in the soil water and tritiated water vapor in the air. The tritiated water content of vegetation has been shown to decrease with distance from the center of the SRS.

Tritium concentrations have been measured in deer and hogs. Tritium enters . animals through drinking surface water and in food. The results of these studies indicate that the tritium content of both the water and organic content of deer reflected the tritium content of the environment around them.

Tritium is measured in a variety of crops (wheat, rye, barley, corn, plums, peaches) and animal food products (beef, eggs, chicken, pork) grown in the vicinity of the SRS. The tritium content of milk and rainwater are very similar. The average tritiated water concentration of crop plants and animal foods is similar to the average concentration of tritium in air moisture.

A number of inadvertent releases of tritium to the environment have been reported during the years of operation. The quantity of tritium in each release and the form (water vapor or gas) have been used to evaluate the effects of the releases. Since much of the environmental tritlum data represents annual average concentrations, the effects of these short releases are not readily apparent. Special sampling has been combined with modeling to study these effects. When the release was in the form of tritiated water vapor, the highest concentrations were found in vegetation leaves. The concentrations dropped rapidly, decreasing to very low values within the first day. The concentration in soil was comparatively small. When the release was in the hydrogen gas form, the righest concentrations were found in the soll water. Tritium concentrations in vegetation decreased much more slowly, with a half time of about 5 days.

Tritium has been released to the groundwater through liquids placed in seepage basins and from the waste burial sites. Each of these entry points has been studied extensively. Some transport through the shallow groundwater aquifers has been documented. There is no indication that tritium contamination in the shallow groundwater aquifer has moved offsite to the public zone. In a few instances, the groundwater aquifers outcrop to a stream which flows offsite to the Savannah River.

The fate of all tritium that has been released from SRS facilities since the site began operation has been assessed. Using the environmental measurements and release data as input to a model, it was determined that, at the end of $1988,91 \%$ of the tritium remaining in the environment, after decay, is 
in the surface ocean (47\%) or the deep ocean $(44 \%)$. This represents a surface ocean tritium concentration, due to SRS operation, of 0.2 $\mathrm{pCi} / \mathrm{L}$.

The tritium in the atmosphere and soil have decreased slowly since a peak in 1957. This reflects the trend of decreasing releases from SRS operations since the peaks of the early $1950 \mathrm{~s}$. The decrease in the surface and groundwater tritium inventory is slower, with peaks in 1965 and 1973, respectively. This reflects the slower turnover of the groundwater.

The tritium concentrations in the environment have been used to assess the dose and risk to the general population in areas surrounding SRS due to SRis tritium releases. A number of well-documented models were used in this effort. The models evaluate the transport of tritium to people through a number of different pathways. Based on 1988 data, the "maximum" individual living on the site boundary received $0.30 \mathrm{mrem}$ from atmospheric releases and 0.10 mrem from liquid releases. For comparison, the same individual received about $300 \mathrm{mrem}$ from natural sources and another $70 \mathrm{mrem}$ from medical radiation and consumer products.

The cumulative dose to the population within a 50-mi radius from atmospheric and liquid releases from the SRS during $35 \mathrm{yr}$ of operation was about 1500 person-rem distributed among 625,000 people. Using EPA risk estimates, about 0.6 excess fatal cancers may be associated with this collective dose. The same population is expected to have about 105,000 cancer fatalities from all types of cancer. Therefore, it is unlikely that a relationship between any of the cancer deaths occurring in this population and the releases of tritiL'm from the SRS will be found.
The tritium concentrations in the environment have been compared to applicable EPA limits. It was shown that at $1 \mathrm{mi}$ from the site center, the atmospheric tritium concentration due to SRS operations is about 0.4 of the 40 CFR 61 concentrations guide for tritium of $1.5 \times 10^{-9} \mathrm{Ci} / \mathrm{m}^{3}$. At $10 \mathrm{mi}$ (approximately the site boundary), the concentration is about 0.067 of the limit. The concentration of tritium in the Savannah River, just downstream from the site, due to SRS operations is 0.17 of the limit set by the Drinking Water Standard (DWS) of 20,000 $\mathrm{pCi}$. The concentration at downstream water supplies is about 0.13 of the DWS limit. 
Tritium is released to the environment from many of the operations at the Savannah River Site. The releases from each facility to the atmosphere and to the soil and streams, both from normal operations and inadvertent releases, over the period of operation from the early 1950 s through 1988 are presented. The fate of the tritium released is evaluated through environmental monitoring, special studies, and modeling. It is concluded that approximately $91 \%$ of the tritium remaining after decay is now in the oceans. A dose and risk assessment to the population around the site is presented. It is concluded that about 0.6 fatal cancers may be associated with the tritium released during all the years of operation to the population of about 625,000 . This same population (based on overallU.S. cancer statistics) is expected to experience about 105,000 cancer fatalities from all types of cancer. Therefore, it is considered unlikely that a relationship between any of the cancer deaths occurring in this population and releases of tritium from the SRS will be found. 
The Savannah River Site (SRS) was established in 1952 with the mission of producing nuclear materials, primarily tritlum and plutonium, for national defense. Manufacture of these materials began in 1954 with the start of the first nuclear reactor. Operation of the SRS has resulted in the release of low levels of radioactive materials to the atmosphere and the surface waters leaving the site. From the beginning of the site's operation, the levels of materials were monitored to ensure the safety of the site workers and the surrounding popilation. The results of the monitoring activities have been released to the public since 1965, when it was felt that this information would no longer compromise the secret nature of some of the defense-related functions of the site.

During the 1980 s, the operation of the site came under closer scrutiny of the public and environmental regulatory agencies. The past record of monitoring activities has been invaluable in documenting the releases of raclioactive materials and in supporting their negligible effect on the public. The frequent use of the information from the monitoring reports and other information from individual research projects suggested that it would be profitable to compile this information in a form that would summarize the important findings and reference the original publications.

This report is the first in a series of reports on radionuclides in the SRS environment. Tritium was chosen as the first radionuclide in the series because the calculations used to assess the dose to the offsite population from SRS releases indicate that the dose due to tritlum, though of small consequence, is the most important of all of the radionuclide doses. This was recognized early in the site operation, and extensive measurements of tritium in the atmosphere, surface water, and groundwater exist due to the efforts of the Health Protection Department's Environmental Monitoring Section. In addition, research into the transport and fate of tritium in the environment has been supported at SRS by both the local Department of Energy (DOE) Offic and DOE's Office of Health and Environmental Research.

This report is divided into three sections summarizing the releases of tritium from the site facilities, the transport and concentrations of tritium on and in the vicinity of SRS, and the description and results of the assessment of dose to the surrounding public from the releases. A description of the site monitoring network is included. A bibliography of pertinent SRS publications provides a source of further information for individuals who want more details about information in the report.

This document is intended to show the great effort that has been expended to understand the consequences of the tritium releases from SRS. It is hoped that the readers will understand that this effort was made to safeguard the safety and health of those who work at SRS and those who live near its boundaries. 


\section{INTRODUCTION}

The nuclear reactions that produce tritium at the Savannah River site (SRS) are principally the fission of lithium by neutron irradiation of targets, the reaction of neutrons with the heavy water moderator used in reactors, and the ternary fission ot transuranic elements in the reactor fuels and targets. Operations involving production and handling of radionuclides at SRS result in the release of some tritium to the environment.

Tritium is released from reactor operations (reactor facilities), recovery of transuranic elements (separations facilities), recovery of tritium (tritlum facilities), laboratory research, and a heavy water rework facility. The receiving media for these releases are the atmosphere, site streams, and the ground (from seepage basins and burial ground). This section describes the sources of tritium releases and their routes to the environment. Figure 1.1 is a map of the SRS which shows the location of the principal areas within the site.

\section{REACTOR FACILITIES}

Most of the tritium released from SRS reactor facilities results from heavy water moderator that becomes exposed to environmental water or air. Liquid releases account for $14 \%$ of the approximately 8 million curies (Ci) of tritium released from SRS reactor facilities from startup through 1988, and atmospheric releases for $86 \%$ (Zeigler and Lawrimore 1988).

The tritium concentration in reactor moderator ranges from approximately $17 \mathrm{Oi}$ per liter $(\mathrm{Ci} / \mathrm{L})$ in $\mathrm{C}, \mathrm{K}$, and $\mathrm{P}$ Reactors to approximately $3 \mathrm{Ci} / \mathrm{L}$ in $\mathrm{L}$ Reactor. The low tritium concentration in L-Reactor moderator is due to the relatively tritium-free moderator used for restart and the short operating interval since restart.

Tritium in aqueous solution is transferred to the environment from fuel and target storage (disassembly) basins, direct leakage of moderator from the process heat exchangers to couling water, and miscellaneous sources.

Tritium is transferred from the reactor to the fuel and target storage basins principally by the adherence of moderator to the surface of the components and entrapment of moderator in the fitting of the components. Transfer also occurs in the hydrated oxide film on the aluminum surfaces of reactor compionents. The tritium in the moderator exchanges rapidly with hydrogen in the water of the storage basins untll equilibrium is reached.

Tritium from the fuel storage basins reaches the environment when the storage basin water is replacied (purged) wi.h "clean" water. Purging is necessary to control exposure to operating personnel from tritiated water that evaporates from the storage basins.

When the reactors began operation in 1954 and 1955, a continuous purge of several thousand gallons of water per minute was used to maintain clarity and to cool the fuel and target storage basins. As tritium concentrations in the reactor moderator increased, the resulting increase in tritium releases led to the institution of control measures to reduce the quantity of tritium released to streams.

In the late 1950s, the volume of continuous flow was reduced, and some of the overflow weirs were closed. In 1963, the vertical tube storage (VTS) sections of the disassembly 


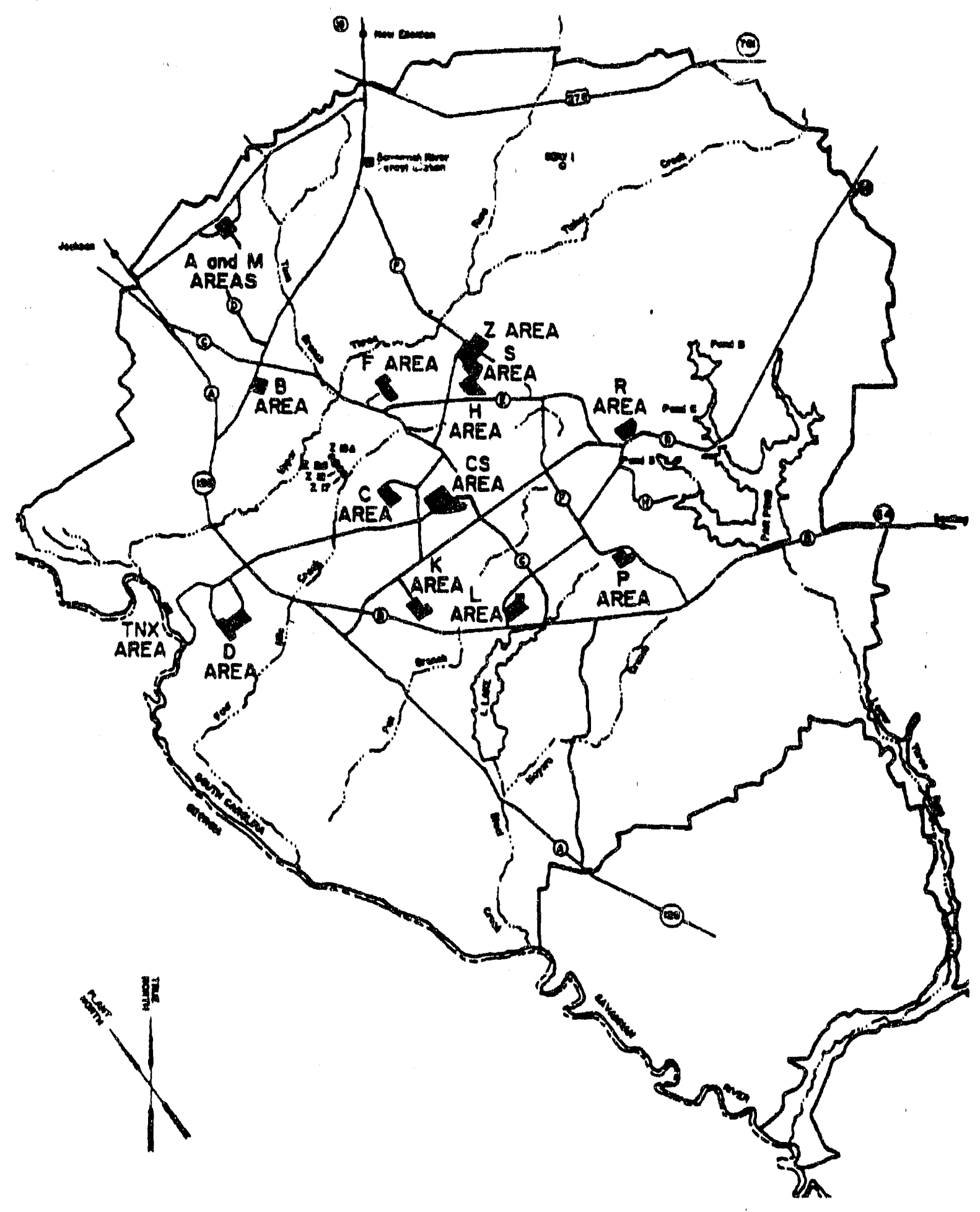

Figure 1.1. Map of the Savannah River Site 
basins were modified so that the VTS could be isolated from the other disassembly basins, and provisions were made to circulate VTS water through a portable filter/delonizer system. Heat was removed by heat exchangers that were installed on the roof of the disassembly areas. Water discharged from the VTS was isolated and recirculated through the filter/deionizer system.

After reactor component discharge was complete, the water was routed either to a seepage basin or to the effluent stream until the tritium concentration in the VTS was low enough to allow the isolation gates to be opened to the other basins. Tests indicated that the delonizers were the more effective mechanism of particulate removal, and the use of filters was discontinued. In addition, a reactor component flushing system was installed to remove a significant quantity of the moderator from the components as they were discharged from the reactors.

In the early 1970 s, permanent sand filters were installed to maintain clarity in the disassembly basins, and all overflow weirs were closed. The residue collected on the sand filters is transported to 200-F for processing and storage in the waste tanks. The method of purging the VTS, however, is still in use.

Since the late 1950 s, tritium released to the environment from fuel and target basin purges has been directed to streams or to seepage basins. When released to streams, the purge water is mixed with the much larger volumes of heat exchanger cooling water, resulting in concentrations that are very low and well within the prevailing release limits. When purge water is placed in seepage basins, a significant part of the tritium decays before it migrates to streams and travels offsite.
Therefore, the preferred method is to purge to seepage basins.

The process heat exchangers are used to remove heat from the reactors. Heavy water moderator is circulated through the tube side of the heat exchangers and river or pond water through the shell side. Minute leaks allow a small amount of tritium to migrate to the shell side, from which it is discharged to reactor effluents.

Miscellaneous releases include water from the shell side of the fuel and target storage basin heat exchangers, process area sumps, and a variety of other small sources.

Tritium releases from reactor areas to the atmosphere result from moderator evaporation from occasional purges of the blanket gas system. Evaporation of moderator from reactor control rods and guide tubes and from pipe flange and valve connections also results in tritium release to the atmosphere. Small quantities of moderator are exposed to the atmosphere during maintenance and fuei discharge operations. Atmospheric tritium is removed from the reactor building through a filtered ventilation system that discharges to a 60-m stack.

Evaporation from reactor fuel and target storage basins and earthen seepage basins are additional minor sources of atmospheric tritium releases.

\section{C-Reactor Area}

C Reactor operated from 1954 until it was placed on standby in 1987. Tritium-bearing liquid effluents from the fuel and target storage basin and miscellaneous sources were discharged to either the 904-66G seepage basin or Four Mile Creek. The seepage basin 
received discharges from 1959 to 1970 and from 1978 to 1985. Between 1955 and 1959, and between 1970 and 1978, discharges were directed to Four Mile Creek. Four Mile Creek also received reactor heat exchanger cooling water effluents which contained small quantities of tritium.

Approximately $99 \%$ of the C-Reactortritium released to the atmosphere was discharged through the 60 -m stack on the reactor building, and approximately $1 \%$ was released through evaporation from fuel and target storage basins.

The history of the C-Reactor Area tritium discharges is illustrated in Figure 1.2. The figure shows an increase in (discharges during the early years of operation as the tritium content of the moderator increased. The discharges approached a steady rate after 1965. The increases in 1984 and 1985 were due to small leaks from the primary reactor vessel to the secondary leak containment cavity. The leaks occurred at inner stress corrosion cracks at several welds in the reactor vessel and led

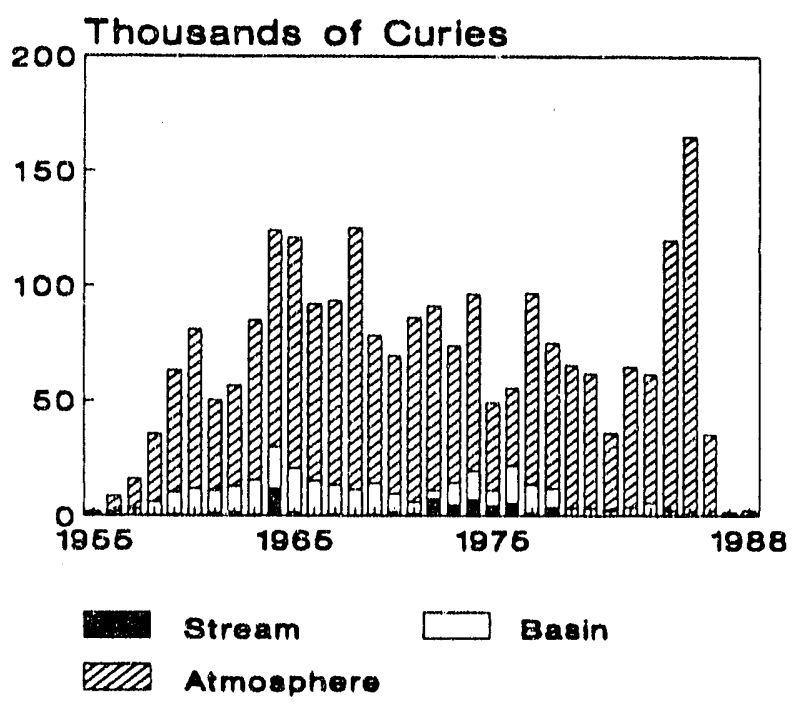

Figure 1.2. C-Reactor Tritium Releases to a reduction in reactor operation in 1986 and a complete shutdown in 1987.

\section{K-Reactor Area}

KReactor has operated since 1954. Liquid effluents from fuel and target storage basin purges and other miscellaneous sources have been discharged to Pen Branch, the 904-65G seepage basin, and the 904-88G containment basin during the operating history of the reactor.

Prior to 1966, liquid wastewater effluents were discharged to Pen Branch, except for $500 \mathrm{Ci}$ in 1959 and $4700 \mathrm{Cl}$ in 1965, which were discharged to the 904-65G seepage basin. (This basin was not used extensively because of undesirable seepage characteristics.) Since August 1965, a limited portion of the 904-88G containment basin has been used to receive fuel and target storage basin purges and other miscellaneous releases.

The water from the 904-88G containment basin migrates through a shallow groundwater aquifer and outcrops into Indian Grave Branch, a tributary to Pen Branch. Migration of tritium from the containment basin to Pen Branch has been measured since 1969. Pen Branch also receives reactor heat exchanger cooling water from $\mathrm{K}$ Reactor which contains small concentrations of tritium.

Approximately $99 \%$ of the tritium released to the atinosphere was discharged through the $60-\mathrm{m}$ stack on the reactor building, and approximately $1 \%$ was released through evaporation from fuel and target storage basins.

Total atmospheric and liquid releases of tritium from K-Reactor Area increased during the early years of operation as the tritium 


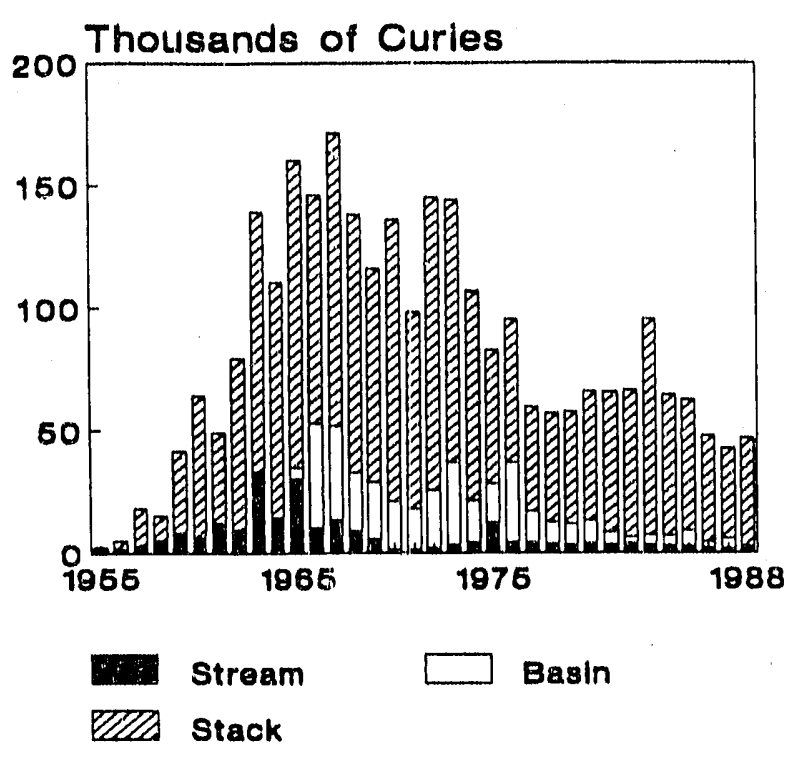

Figure 1.3. K-Reactor Tritlum Releases

content of the moderatorincreased (see Figure 1.3). The discharges reached a peak in 1967 and then showed an overall decrease through 1988. When assessed separately, except for 1983, liquid and atmospheric releases followed a similar pattern throughout the 1955 to 1988 period. The spike in atmospheric tritium releases in 1983 was related to numerous line breaks during an extended outage in June and July.

\section{L-Reactor Area}

L Reactor operated from 1955 to 1968 , when the reactor was placed on standby. It was refurbished and restarted in 1985. Liquid effluents from fuel and target storage basins and miscellaneous sources were discharged to the 904-64G seepage basin intermittently in 1958 and 1959, 1961 to 1965 , and 1967 to 1969. At other times, discharges were released to Steel Creek. When LReactor was restarted in 1985, liquid wastewater effluents were again directed to the $904-64 \mathrm{G}$ seepage basin.
Monitoring stations on Steel Creek had not detected any outcropping of tritium from the 904-64G seepage basin prior to construction of L Lake. Any future outcropping to L Lake would be virtually imfossible to measure because the outcrop would occur at the edge of L Lake.

Heat exchanger cooling water containing small amounts of tritium was discharged to Steel Creek from 1955 to 1968. After the reactor was restarted in 1985, heat exchanger cooling water was discharged to L Lake, which overflows to Steel Creek.

Approximately $99 \%$ of the tritium released to the atmosphere was discharged through the $60 \mathrm{-m}$ stack on the reactor building, and approximately $1 \%$ was released through evaporation from fuel and target storage basins.

The 904-83G oil and chemical basin was used from 1961 to 1979 to receive miscellaneous liquid wastewater containing oil and chemicals from all of the reactor areas (see Figure 1.4). This waste was transported

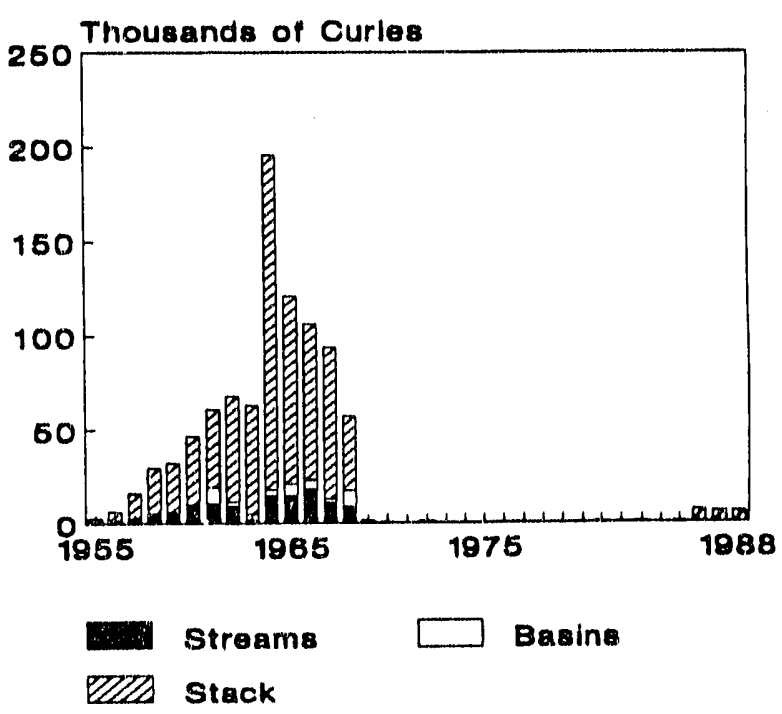

Figure 1.4. L-Reactor Tritlum Releases 
in either tanker trucks or barrels, and the quantity of radioactivity present was measured before the waste was placed in the basin. The 904-83G oll and chemical basin is close to the L-Area seepage basin, and no outcrop had been detected in Steel Creek prior to the construction of L Lake.

Total liquid and atmospheric releases of tritlum from the L-Reactor Area increased from startup until 1964, as the tritlum content of the moderator increased (see Figure 1.5). The peak annual release to the atmosphere of $180,000 \mathrm{Cl}$ in 1964 resulted from small moderator leaks at valves and flanges during the first half of the year and extensive maintenance associated with the Phase III containment outage during the second half of the year. Discharges decreased after 1964 and ceased after 1968 when the reactor was placed on standby status.

Releases after restart of the reactor in 1985 were much lower than during the period prior to shutdown because of the low tritium

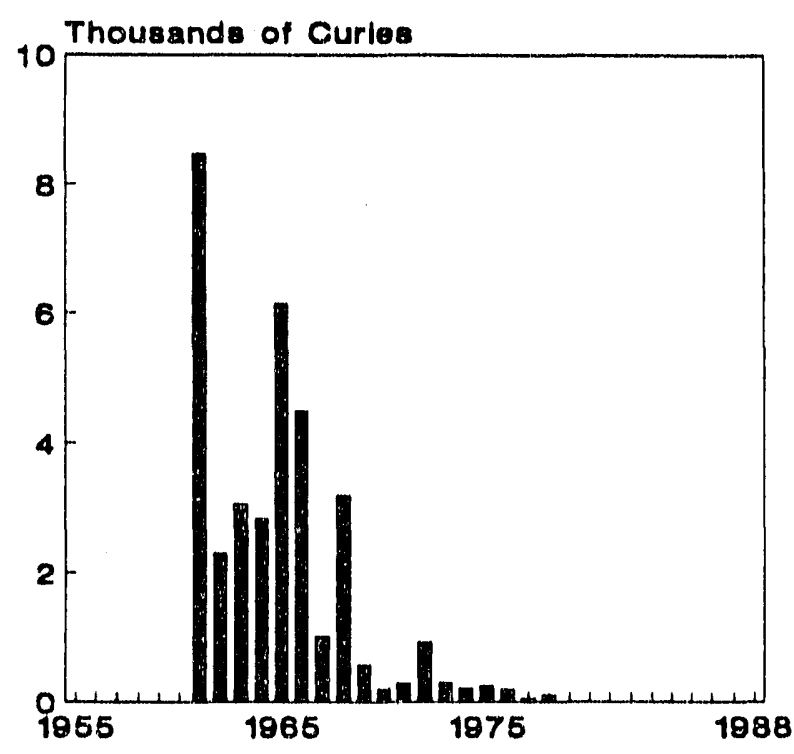

Figure 1.5. Tritium Releases to the L-Area Oll and Chemical Egsin content of the moderator used for restart. Liquid releases followed the same pattern as atmospheric releases except for the peak in 1964 and the continued release of a small amount of tritium to Steel Creek untll 1970.

\section{P-Reactor Area}

$P$ Reactor has been operational since 1954. Liquid effluents from fuel and target storage basin purges and other miscellaneous sources have been discharged to Steel Creek, the 904-61G seeprge basin, and Par Pond during the operating history of the reactor. Fuel and target storage basin purges containing tritlum were discharged to Steei Creek and the 904-61G seepage basin in the years shown below:

\begin{tabular}{ll} 
Steel Creek & Seepage Basin \\
\hline 1954 to 1956 & 1957 to 1968 \\
1969 & 1970 \\
1971 to 1977 & 1978 to 1988
\end{tabular}

Reactor heat exchangercooling water and miscellaneous effluents were discharged to Steel Creek until 1963, when most of the reactor heat exchanger cooling water was diverted to Par Pond. With the construction of L Lake, the remaining reactor heat exchanger cooling water and all miscellaneous wastewaters were also diverted to Par Pond.

When all $P$. Reactoreffluents were diverted to Par Pond, migration of a small amount of tritium from the 904-61G seepage basin to Steel Creek was detected (170 Ci in 1985). In earlier years, migration of this small amount of tritium was obscured by the much larger heat exchanger cooling water flow. The tritium discharge from Par Pond to Lower Three Runs Creek has been measured since 1964.

The majority of the atmospheric tritium (99\%) is released to the atmosphere through a $60-\mathrm{m}$ 


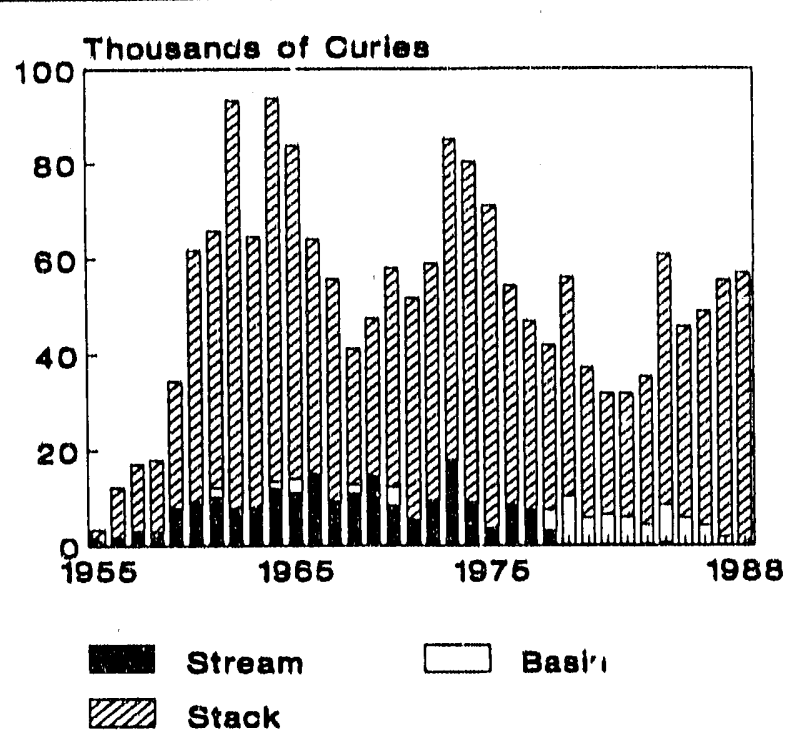

Figure 1.6. P-Reactor Tritium Releases

stack on the reactor bullding, with a small amount $(1 \%)$ released through evaporation from the fuel and target storage basin area.

Total discharges of tritium from P-Reactor Area, shown in Figure 1.6, Increased from startup until 1964, when $92,000 \mathrm{Cl}$ were discharged due to the increase in the tritium content of the moderator. After 1962 discharges varied widely, with an average of approximately $50,000 \mathrm{Ci}$ per year. Liquid released followed the same general trends as the atmospheric releases until 1987, when a decrease occurred.

\section{R-Reactor Area}

R Reactor operated from 1954 until 1964, when it was placed on inactive status. Fuel and target storage basin overflow was discharged to Lower Three Runs Creek, Par Pond, and the 904-60G seepage basin. From 1954 to 1958 , the overflow was directed to Lower Three Runs Creek. From 1958 to 1964 , the release of fuel target storage basin overflow was alternated between the 904$60 \mathrm{G}$ seepage basin and Par Pond.

Heat exchanger cooling water and miscellaneous effluents sontaining tritlum were released to Lower Three Runs Creek from 1954 to 1958. AfterParPond was constructed and placed in operation in January 1959, this water was released directly to Four Mile Creek until a canal and pond system, ultimately emptying into Par Pond, was placed in operation in 1961.

The majority of the atmospheric tritium was released through a $60 \mathrm{~m}$ stack on the reactor building.

Total discharges of tritium from R Reactor increased during operation due to the increase in the tritlum content of the moderator. Tritium releases peaked at about $70,000 \mathrm{Cl}$ in 1964, the last year of operation (see Figure 1.7). Liquid releases from the fuel storage basins followed the general trends of the atmospheric releases throughout the operational period.

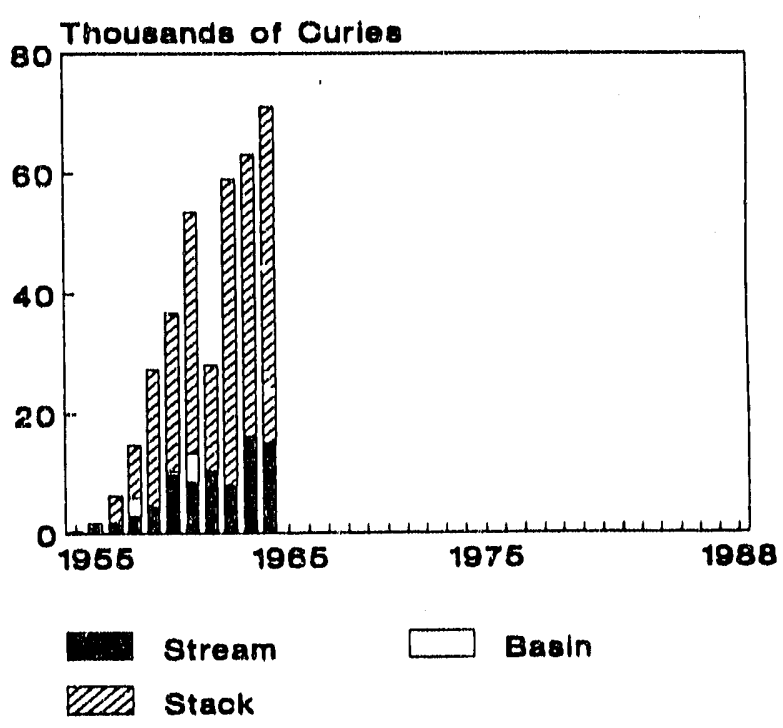

Figure 1.7. R-Reactor Tritlum Releases 


\section{SEPARATIONS FACILITIES}

Separations facilities that have tritium emissions include:

- the fuel and target reprocessing facilities,

- the tritlum facilitles,

- the receiving basin for offsite fuel,

- the $F$ and $H$ seepage basins, and

- the waste evaporators and storage tanks.

The quantities of tritium released from the fuel and target reprocessing facilities ( $F$ and $\mathrm{H}$ Canyons), the tritium facilities, and the receiving basin for offsite fuel (RBOF) are combined for reporting purposes to avold the security classification that applies to tritium releases from a specific facility.

The $F$ and $H$ Canyons process enriched uranium fuels and depleted uranium targets which are irradiated in SRS reactors. Tritium is released during the reprocessing of this fuel. The tritium facilities process lithiumaluminum targets which are also irradiated in SRS reactors. At RBOF, a small quantity of iiftium is released from the cleaning of tritium targets before they are processed in the tritium facilities, from the processing of deionizers used in the reactor areas, and from tritium that escapes from stored fuels.

Except forthe $\mathrm{F}$-and $\mathrm{H}$-Canyon processes, releases from these sources are routinely monitored and reported. Releases from the $\mathrm{F}$ - and $\mathrm{H}$-Canyon processes are calculated annually based on the processed fuel irradiation history and the fraction that is vaporized.

Small amounts of tritium also evaporate from the $F$ and $H$ seepage basins, from the high-level-waste storage tanks, and from the evaporation of waste at the tank farms. These releases are elther estimated or based on periodic measurements.

\section{$F$ and $H$ Canyons}

$F$ and $\mathrm{H}$ Canyons have been in operation since their respective startup dates of December 1954 and July 1955. In the canyons, ternary fission product tritium follows the process liquid streams, less some fraction that evaporates and exits through canyon stacks. In the liquid streams, some of the tritlum is released in overheads from waste reduction evaporators and a small amount remains in the high-level waste that is directed to the waste storage tanks (tank farms). Another minor source of tritium is wastewater from the reactor areas that is processed in $F$ Area. This wastewater originates from sumps, the fuel and target storage basin sandfilters, and other miscellaneous reactor operations.

Prior to 1988 the primary tritium-bearing wastewater from the separations facilities was discharged to the $F$ and $H$ seepage basins. Water from the seepage basins percolates through the soil column to the shallow aquifers and then migrates to an outcrop along Four Mile Creek. The quantity of tritium migrating from $F$ and $H$ seepage basins to Four Mile Creek has been measured since 1959. (The basins were placed in operation in 1955.)

In 1988 a new effluent treatment facility (ETF) was placed in operation to remove particulate and dissolved radioactivity and to remove or neutralize chemicals from the wastewater formerly discharged to the seepage basins. The ETF treatment process is not capable of removing tritium, so the tritium is contained in the discharge from the ETF to Upper Three Runs Creek. 
Closure of the $\mathrm{F}$ and $\mathrm{H}$ seepage basins is underway, but migration and outcropping of this tiitlum in Four Mile Creek will not imimediately stop because of the inventory of tritium that exists in groundwater under the seepage basins. After closure, the quantity of tritlum reaching Four Mile Creek is expected to decline slowly as the amount of tritium is depleted and tritium decay occurs. Approximately $440,000 \mathrm{Cl}$ of aqueous tritium have been released to the environment from $F$ and $H$ Areas from 1954 through 1988.

A small quantity of tritium from other miscellaneous separations process sources is also released in wastewater that is discharged to Four Mile Creek.

\section{$F$ and $H$ Seepage Basins}

$F$ and $H$ seepage basins were used for disposal of wastewater from 1955 until 1988 (see Figure 1.8). Approximately $30 \%$ of the tritium released to the seepage basins dissipates by evaporation to the atmosphere. The remaining tritium either percolates through the soll to the upper groundwater aquifers, or it decays to nonradioactive helium. Tritium beneath the basins migrates with the flow of the groundwater and eventually outcrops into Four Mile Creek.

The quantity of tritium migrating from the basins has generally increased since measurements were first made in 1958. Based on 1985-1987 averages, tritium migration has been approximately $2400 \mathrm{Ci} / \mathrm{yr}$ fiom the F-Area seepage basins and approximately $6000 \mathrm{Ci} / \mathrm{yr}$ from the H-Area seepage basins and the burial ground. (Because of the pattern of outcropping, H-Area seepage basin and burial ground sources cannot be distinguished from one another.)

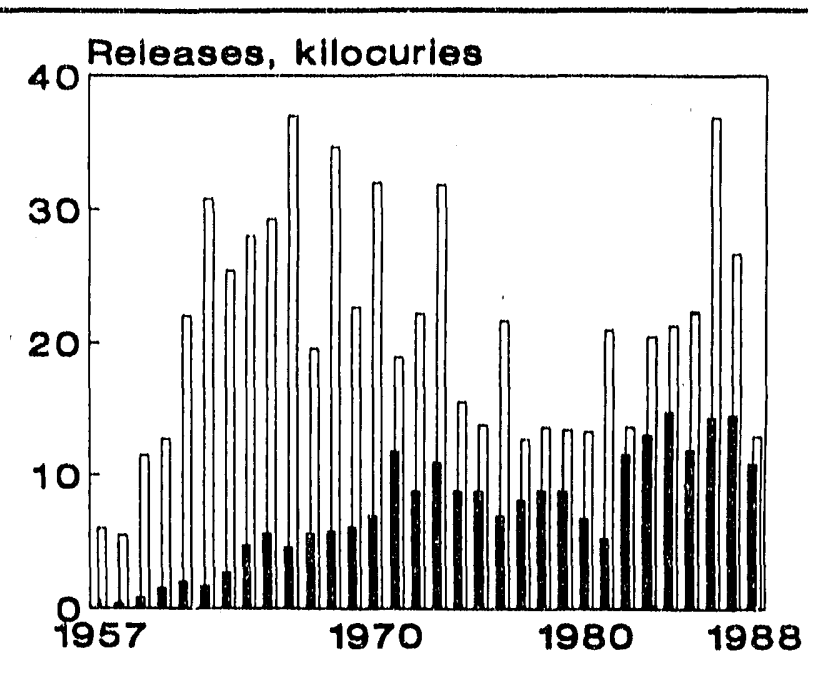

Relogees to Basins

Migration to Straams

Figure 1.8. Annual Tritium Input into the $F$ and $H$ Seepage Basing and the Total Migration to Streams

\section{Tritium Facillities}

The original tritium extraction facility in 232-F operated from 1954 to 1958 . It was replaced by the $\mathrm{H}$-Area tritium facilities which extract, separate, purify, and package tritium. The H-Area tritium facilities have operated continuously since startup in 1957.

Tritium is extracted from irradiated lithiumaluminum targets and then processed and packaged for shipment to other DOE facilities for national defense uses. Tritium facility operations are carried out in process cabinets in which air movement sweeps away tritium that escapes from the equipment. The air is exhausted through three $60-\mathrm{m}$ stacks and one 23-m stack.

The tritium facilities are the largest contributor to SRS atmospheric releases, 


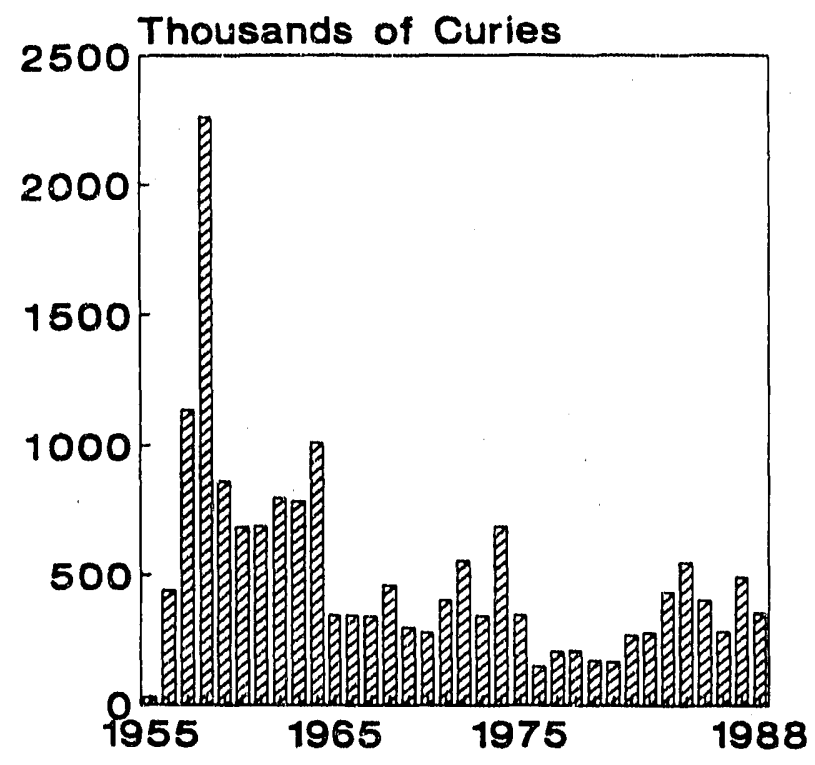

Figure 1.9. Atmospheric Releases of Tritium from the $H$ and $F$ Area Tritium Facilities

with approximately 17.4 million $\mathrm{Cl}$ released from startup through 1988 (see Figure 1.9). These releases typically include both elemental (HT, DT, and $T_{2}$ ) and oxide (HTO, DTO, and $\mathrm{T}_{2} \mathrm{O}$ ) forms of tritium, with a minor amount (less than 1\%) in an organic form (tritiated methane).

Forms of Tritium from the Separations Areas

The radiotoxicities of the different forms of tritium vary widely. Elemental tritium is approximately 25,000 times less radiotoxic than the oxide form (NCRP 1979). In cases where the ratio of elemental to oxide tritium was not known, the SRS practice was to be conservative and assume that all of the tritium released was in the oxide form.

Studies of HT and HTO release ratios from the tritium separations area established that this assumption is excessively conservative.
A study of the HT-to-HTO ratios (where HT represents all elemental forms of tritium and HTO represents all oxide forms) in atmospheric releases from the area was initiated in 1976. Weekly samples of effluents from the four $\mathrm{H}$-Area tritium facilities stacks were routinely collected for $4 \mathrm{yr}$. The results of that study (Figure 1.10) indicated that the overall percentages for the 1976-1979 period were $44 \%$ and $56 \% \mathrm{HT}$ and $\mathrm{HTO}$, respectively (Du Pont 1980). However, significant variations in release rates and $\mathrm{HT}$ - to -HTO ratios were encountered due to differences in the nature of the work and in the operating periods of the various facilities.

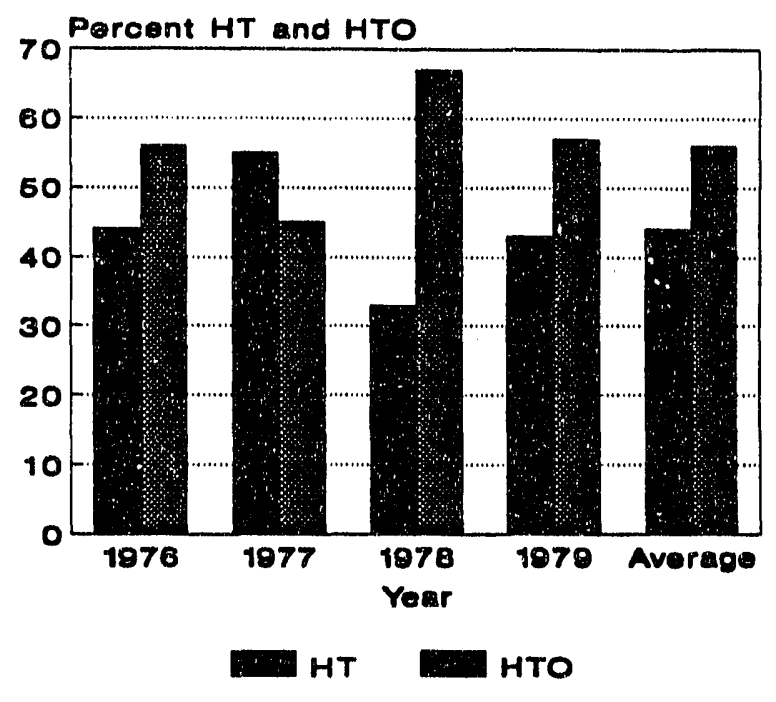

Figure 1.10. HT and HTO as a Percentage of Total Releases from the Tritlum Separations Facilities 1976-1979

The elemental and oxide tritium values generated by collecting effluent samples with molecular sieves did not show good agreement with the estimates of total tritium in the stack gases measured with Kanne chambers. (A description of these sampling methodologies can be found in Appendix 1.) It was therefore concluded from the study that insufficient 


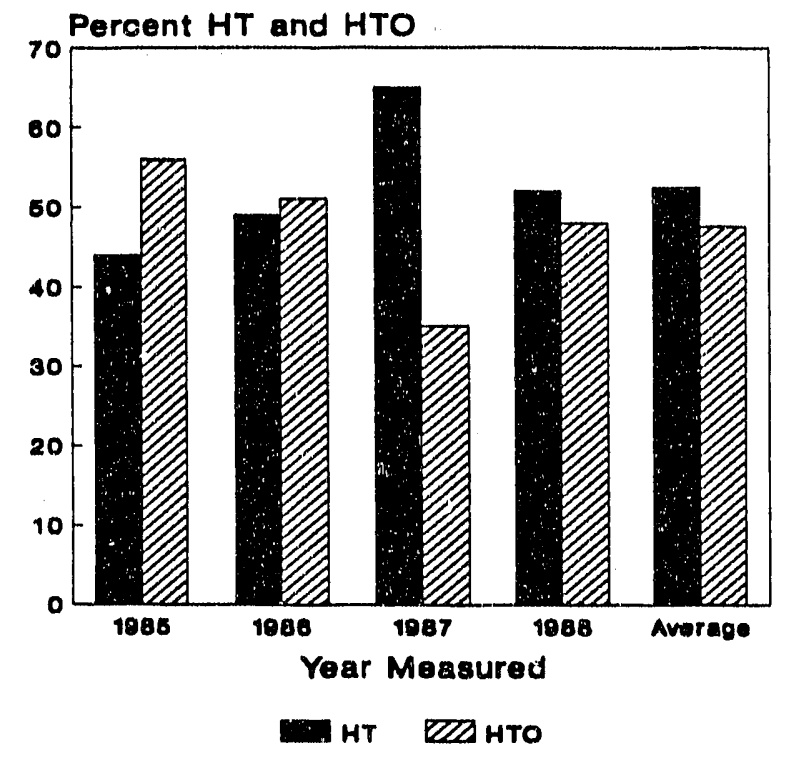

Figure 1.11. HT and HTO as a Percentage of Total Releases from the Tritium Facilities 1985-1988

data were available at the time to base tritium doses exclusively on estimates of tritiated water vapor release levels.

In recent years, advances in stack sampling techniques developed at SRS have produced more reliable elemental and oxide tritium measurements. Advanced systems now include computer-controlled in-line, continuous monitors. Sufficient confidence was gained in the monitoring systems to support the use of measured HT and HTO values for calculating offsite doses beginning in 1985. For the period 1985 to 1988 , the overall HT and HTO percentages for tritium facilities releases were approximately $52 \%$ elemental and $48 \%$ oxide, as shown in Figure 1.11 .

Tritium releases were highest in the early years of operation, with a maximum of 2.3 million $\mathrm{Ci}$ in 1958, when both $\mathrm{F}$ - and $\mathrm{H}$-Area tritium facilities were in operation. Releases have decreased since 1968 to an average of approximately $400,000 \mathrm{Ci} / \mathrm{yr}$ over the past 10 years.

The small quantity of tritium released in miscellaneous liquids is discharged to Four Mile Creek and reported with other H-Area liquids released to streams.

\section{Receiving Basin for Offsite Fuel}

The three major RBOF functions are the storage and packaging of offsite fuel for processing in the canyons, the cleaning of lithium-aluminum targets for processing in the tritium facilities, and the cleaning and recharging of deionizers for use in the reactor areas.

Routine releases of tritium to the atmosphere are very small (on the order of hundreds of curies per year). These releases originate principally from minute leaks from fuel stored in the RBOF basins. Liquid releases to the environment are also very small because tritium from target and deionizer cleaning operations is contained in the liquid waste that is transferred to the waste tank farms (see Figure 1.12). The small quantities of tritium contained in liquid that go to Four Mile Creek are reported with other $\mathrm{H}$-Area liquids released to streams.

\section{Waste Tank Farms}

The high-level liquid radioactive wastes stored in the tank farms generally contain tritium. Some of this tritium evaporates and is vented to the atmosphere from the waste tanks, and some is vaporized in the waste evaporators. Although routine measurements are not made, studies indicate that only a few hundred curies per year are released to the atmosphere from these sources (Harrison 1983). 


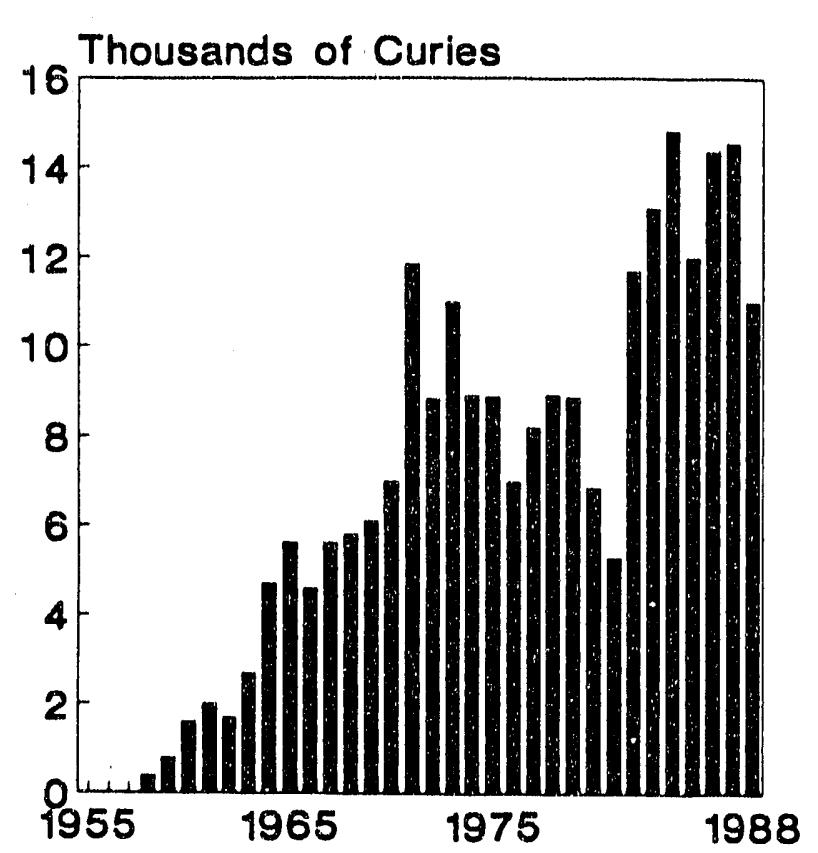

Figure 1.12. Total Liquid Releases of Tritium Directly to Streams from the Separations Areas, Including RBOF

\section{Burial Ground}

The Radioactive Waste Burial Ground is a solid-waste storage facility located between the F- and H-Separations Areas. The burial ground is used to store radioactive solid waste produced at the site, as well as occasional shipments from other Department of Energy facilities.

Tritium-bearing wastes at the burial ground include spent lithium-aluminum targets; oil from pumps; contaminated, failed, or obsolete equipment; resins; and a wide variety of incidental process and laboratory waste from the tritium facilities and the reactor areas. Offsite tritium-bearing wastes are principally tritiated waste from Mound Laboratory.

Approximately 4.2 million Ci of tritium have been disposed of in the burial ground between the beginning of operations (1954) and 1985. The inventory (decay-corrected through 1988) was approximately 1.5 million $\mathrm{Ci}$.

Tritium has been detected in groundwater beneath five zones in the burial ground. The pattern of sritium in groundwater forms essentially two plumes: one beneath 643-G that is migrating toward Four Mile Creek and one beneath 643-7G which is migrating toward Upper Three Runs Creek (Jaegge etal. 1987).

In 1984 it was estimated from groundwater well measurements that approximately 40,000 $\mathrm{Ci}$ of tritium were present in the groundwater below the burial ground. Some outcropping of tritium to Four Mile Creek occurs from the plume that is migrating from 643-G. However, because of the proximity of $\mathrm{H}$ Seepage Basin Number 4, present measurement methods are not capable of differentiating between the two sources. In 1987, the quantity of tritium migration from 643-G and $H$ Seepage Basin Number 4 was $5630 \mathrm{Ci}$.

No outcropping to Upper Three Runs Creek has been detected from the 643-7G plume. Studies indicate that essentially all of this tritium will decay before reaching Upper Three Runs Croek.

\section{OTHER AREAS}

Comparatively small releases of tritium to the environment have taken place at five other locations at SRS: the Heavy Water Rework Facility in D Area, the Savannah River Laboratory (SRL), the Semi-works at TNX, the 320-M Laboratory, and the reactor heat exchanger rework facility in Central Shops.

The aqueous and atmospheric releases at the Heavy Water Rework Facility result from cleanup and reconcentration of degraded heavy water from the reactors. Tritium releases from these facilities are generally 
small (several thousand curies per year).

The releases of tritium from SRL, TNX, and $320-\mathrm{M}$ are the result of tritium research and development projects, most of which occurred in the early years of site operation. A small amount of tritium was also released during repairs to heat exchangers at Central Shops.

The total releases from these facilities through 1988 was about $239,000 \mathrm{Ci}: 39 \%$ to the atmosphere and $61 \%$ to streams and lakes. Less than $1 \%$ was released to the SRL. or Central Shops seepage basins.

\section{INADVERTENT TRITIUM RELEASES}

By definition, an inadvertent release is one which was not planned. Such a release is the result of an unexpected sequence of events, or a failure in a process, which causes a release to the environment. For the purpose of this report, determination of the impact of SRS tritium releases, the identification of significant inadvertent releases is not always consistent with this definition.

In the early days of SRS operation, relatively large releases were expected because of the development work for new facilities and new operating procedures. These releases were not inadvertent and were not documented as such.

This contrasts with the present situation, where very small releases are identified as inadvertent because they are evidence of some malfunction in the process which will require correction. Chapter 2 contains a discussion of the significant, recorded, inadvertent releases of tritium to the environment. Figure 1.13 illustrates some of the characteristics of these releases.

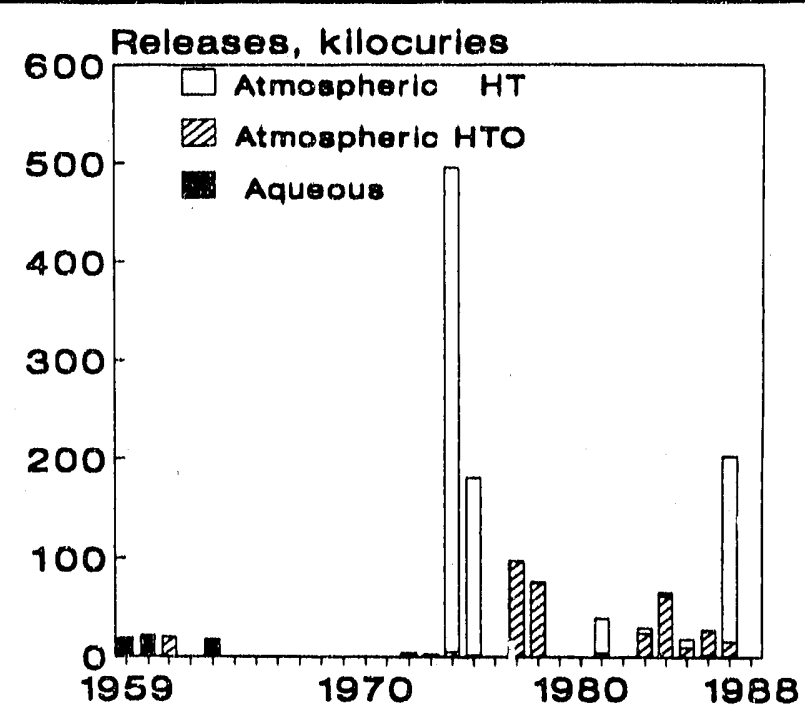

Figure 1.13. Inadvertent Tritium Releases from SRS Facilities Showing Type of Release and Chemical Form of Tritium

For this report, "significant" has been defined as an unplanned event which resulted in a release greater than $0.1 \%$ of the average annual releases. This is approximately $700 \mathrm{Ci}$ for an atmospheric release and $70 \mathrm{Ci}$ for an aqueous release.

Certain trends characterize the inadvertent releases. There were no recorded inadvertent releases before 1959. Most inadvertent releases between 1959 and 1974 were related to reactor operations and were atmospheric or aqueous releases of tritiated water resulting from reactor moderator losses.

Beginning in 1974 and continuing into 1987, there have been a series of releases from the tritium facilities. These releases have been traced to aging equipment in the facility and are one of the reasons for the construction of a replacement tritium facility at SRS.

Most of the tritium released was in the form of tritiated hydrogen gas. Although the quantity 
of tritium released from the tritium processing area over the entire period of operation is much larger than that released from the reactor areas, the radiotoxicity of tritiated hydrogen gas (tritlum facilities) is much less than that of tritiated water (reactor facilities).

These inadvertent releases are included in the release data presented previously.

\section{SUMMARY OF SRS TRITIUM RELEASES}

Tritium has been released to the environment beyond the site boundaries as:

- tritiated water vapor and gaseous, elemental tritium released to the atmosphere through stacks and evaporation from seepage and retention basins and as

- tritiated water released to streams through liquid effluents and through seepage basin and burial ground releases that entered shallow groundwater aquifers and outcropped into site streams.

A summary of releases in these categories is given in Table 1.1. For atmospheric releases, the reactor areas contributed $27.8 \%$, the separations areas $72.8 \%$, and "other" facilities $0.4 \%$ of the total. For streams the percentages are 75.1 from reactors, 15.3 from separations, and 9.6 from "other" sources.

Tritium released to the atmosphere that reaches the offsite environment is the principal source of the small radiation cose received by the offsite population as a result of SRS production activities.

The tritium released by SRS remaining in the worldwide environment in 1988 is about half of the total released, because the other half has decayed to nonradioactive helium.

Only a part of the tritium released to the seepage and retention basins leavec the site. Of the $3,015,000 \mathrm{Ci}$ of tritium released to the basins, $27 \%$ evaporated from the basin surfaces, $40 \%$ migrated to outcrops and entered surface streams, and $33 \%$ remains under the basins.

Of the 4.2 million $\mathrm{Cl}$ of tritium buried in the burial grounds, 1.5 million $\mathrm{Cl}$ remain. Approximately 40,000 Ci have migrated to the groundwater under the burial site. A large part of the tritium buried in the burial ground will decay before reaching surface water. For this reason some of the tritium released to the seepage basins and almost all of the tritium released to the burial ground do not contribute to the radiation dose to the offsite population.

Figure 1.14 shuws the distribution of releases throughout the period of site operation, before and after correction for

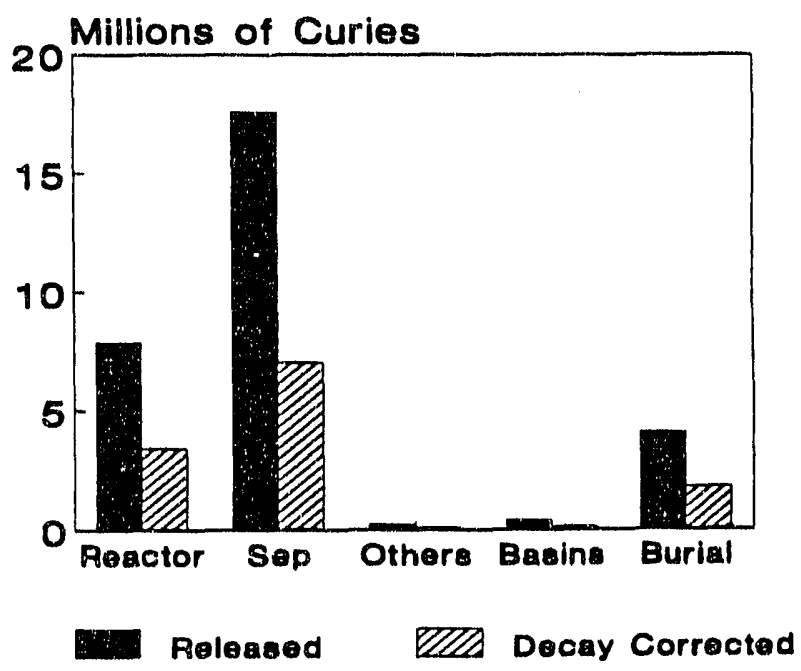

Figure 1.14. Tritium Released by SRS Operations and the Amount of that Tritium Remaining in 1988 After Radioactive Decay 
Table 1.1. Sources of Tritium from SRS Activities, Curies.

$\begin{array}{lrrrr}\text { Facility } & \text { Atmosphere } & \text { Stream } & \text { Total } & \begin{array}{r}\text { Decay } \\ \text { Corrected }\end{array} \\ \text { Reactors } & 6,740,000 & 1,144,000 & 7,884,000 & 3,243,000 \\ \text { Separations } & 17,233,000 & 237,000 & 17,470,000 & 6,577,000 \\ \text { Others } & 93,003 & 145,000 & 238,003 & 102,001 \\ \quad \text { M-Area } & 3 & 0 & 0 & 1 \\ \text { SRL } & 18,000 & 0 & 0 & 5,000 \\ \text { TNX } & 32,000 & 0 & 0 & 9,000 \\ \text { D-Area } & 43,000 & 145,000 & 0 & 88,000 \\ \text { Total } & 24,066,003 & 1,526,000 & 25,592,003 & 9,922,001\end{array}$

Basins and Burial Ground

$\begin{array}{cccc}\text { Output } & \text { Remaining } & \begin{array}{c}\text { Corrected } \\ \text { Input }\end{array} \text { Evaporation Site } & \text { Remaining }\end{array}$

Basins $\quad 1,208,000$

316,000

577,000

154,000

551,000

Burial

Ground 4,200,000

$1,500,000$

radioactive decay. The releases from the reactor area, the separations area, and other areas have entered the atmosphere and streams and are dispersed in the worldwide environment. The tritium retained in the seepage basins and the burial ground remains on the site.

\section{COMPARISON OF SRS RELEASES TO OTHER SOURCES}

The major sources of tritium in the environment are natural production from radiative processes in the upper atmosphere, consumer products containing tritium, nuclear power production, and tests of nuclear explosives. Figure 1.15 compares the inventory of environmental tritium from three of these sources with the contribution from SRS operations.

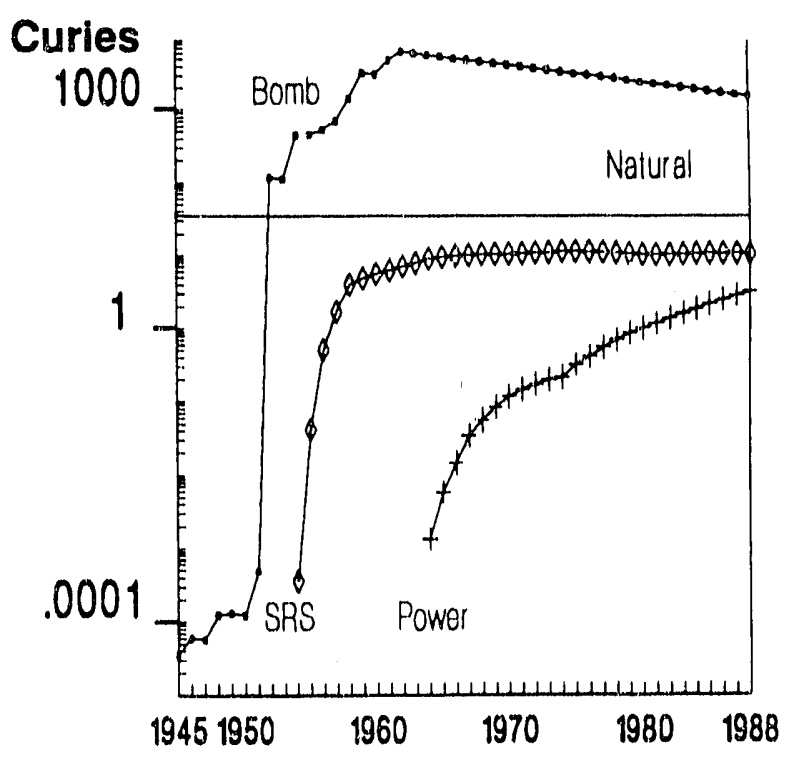

Figure 1.15. A Comparison of Environmental Tritium Inventory Due to SRS Releases and Releases from Other Sources of Tritium 
The largest contribution is from nuclear testing, which began in 1945 and peaked in the early 1960 s. Tritium production increased greatly with the advent of fusion devices. The next largest contribution is from natural production. Most natural production is the result of cosmic ray reactions with nitrogen gas in the upper atmosphere. Natural production has been calculated to be between 4 million $\mathrm{Cl} / \mathrm{yr}$ and 8 million $\mathrm{Cl} / \mathrm{yr}$, which leads to a standing inventory of between 70 million $\mathrm{Cl}$ and 140 million $\mathrm{Cl}$.

Tritium in the environment from nuclear power generation has steadily increased from the early 1960s until it is estimated to be approximately $10 \%$ of the natural inventory in 1988. These figures are based on the estimates of tritium yield per megawatt electric generation contained in the Report of the United Nations Scientific Committee to the General Assembly on the Effects of Atomic Radiation(UNSCEAR 1982), the estimates of commercial nuclear power production found in the Monthly Energy Review 1988 Annual Summary (EIA 1988), and NCRP Report No. 92 (NCRP 1987C). The estimate assumes that the mix of reactortypes and reprocessing facilities during the entire period was the same that was used during the period when the yield was estimated.

Other commercial uses, such as medical and scientific tracers and luminous products, were estimated to have the potential to release as much tritium to the environment as nuclear power. However, the decrease in the use of tritium for back lighting watches suggests that the releases are not this high. The available data do not allow a quantitative estimate of environmental tritium from this source at the present time.

Release data from military production of tritium in other countries are not available.
However, it can be assumed that the major weapons producers have facilities that release amounts of tritium approximately similar to those at SRS.

The inventory due to SRS operation never reached the level of the natural inventory and is much less than the inventory due to nuclear bomb testing. Even though atmospheric testing of nuclear bombs has ceased and the tritium from this activity is decaying, the SRS contribution to the global inventory will not approach $1 \%$ of the total inventory in the foreseeable future. 


\section{Environmental Tritium From Atmospheric Releases}

\section{Transport of Tritlum in the Atmosphere}

Atmospheric tritium is associated with water vapor, hydrogen, and volatile hydrocarbons, primarily methane. In the vicinity of SRS, only tritiated water and tritiated hydrogen have high enough concentrations in the atmosphere to be considered important in dosimetric calculations.

The transport of tritium in the atmosphere is determined by the processes of advection, turbulent diffusion, and deposition (Slade 1968, Pasquill 1968). Advection is the movement of gases or particles in the air with the bulk flow of air. Tritiated gases released to the atmosphere are swept along with the wind and thus move with the general speed and in the general direction of the wind at the time of release.

Turbulent diffusion is the process in which the transport of gases takes place through the action of eddy wind currents. Eddles are often visualized as two-dimensional, circular rotating masses of air that slowly exchange their contents with the surrounding air via mixing at their boundaries.

The movement of gases by turbulence can be characterized by the speed with which the eddies mix with their surroundings, the size of the eddies, and the difference in the concentration of the gas between eddies. The mixing depends on the wind speed, the effects of local heating of the air (buoyancy), and the roughness of the surface of the earth. The result of turbulent mixing is spreading, i.e. an increase in volume of air containing the gas, and decrease in concentration of the gas as it is carried dowriwind from the release point.

The spread of material in the atmosphere is restricted to the volume of air between the ground surface and the height of the surface mixing layer. At the top of this layer, mixing is suppressed by a sudden increase in temperature (an inversion). When the gas has spread to the height of the mixing layer, it is further diluted only by horizontal mixing. The top of the mixing layer is generally much lower at night than during the day. The average daily height of the mixing layer is also lower in the winter than in the summer.

Once the gas has spread through the volume of air in the mixing layer, the gas concentration averaged over circular arcs around the release point will decrease at a rate that is proportional to the inverse of the distance from the release point. In other words, the further the gas moves from the release point the greater the volume of air in which it will mix and the faster its concentration will decrease. As will be demonstrated later, this idea proves useful in analyzing air concentration data collected around release points. Measured concentrations of material released to the atmosphere, if dispersion is occurring in the manner described above, will be distributed along a straight line when plotted against the distance to the sampling station on a logarithmic scale.

Deposition of a gas is the sum of the processes that remove it from the air and deposit it on the soil, vegetation, water, or other surfaces of the earth. Deposition processes are usually classified as wet or dry, depending on whether precipitation is involved in the deposition process. One of the dominant factors determining the deposition rate is the 
concentration of the gas in the air above the surface. Therefore, the spatial distribution of the deposited material is usually similar to the distribution of the gas concentration in the alr.

\section{Annual Average Tritiated Water Concentrations}

Measurements of tritlum content of atmospheric water vapor have been made since the early 1960 s at a network of monitoring stations at SRS. The average annual concentrations resulting from these measurements have been reported in the semiannual and annual reports of the Health Protection Department (see bibllography for complete listing of these titles). These data document the transport of tritiated water vapor at SRS in some detail. The monitoring techniques are described in Appendix 1.

The majority of the monitoring stations are located in two rings around the site. The inner ring is approximately $15 \mathrm{~km}$ from the center of SRS, and the outer ring is $40 \mathrm{~km}$ from the center. The concentrations around each ring are nearly the same for most years, indicating that there is little preferred direction for tritium transport from SRS. The annual wind direction frequency at SRS is nearly the same from all directions. Figure 2.1 shows isopleths of the average concentration of tritiated water in air and the inverted wind rose for the 5-year period from 1982 through 1986 (points are in the direction which the wind is going rather than the normally reported direction the wind is coming from).

The wind blowing inward from the center of the site is shown as proportional bars (the longest bar represents an average wind speed of $30 \mathrm{~km} /$ day in the direction of the bar from the site center). The slightly greater tritium conceniration in the east and west directions

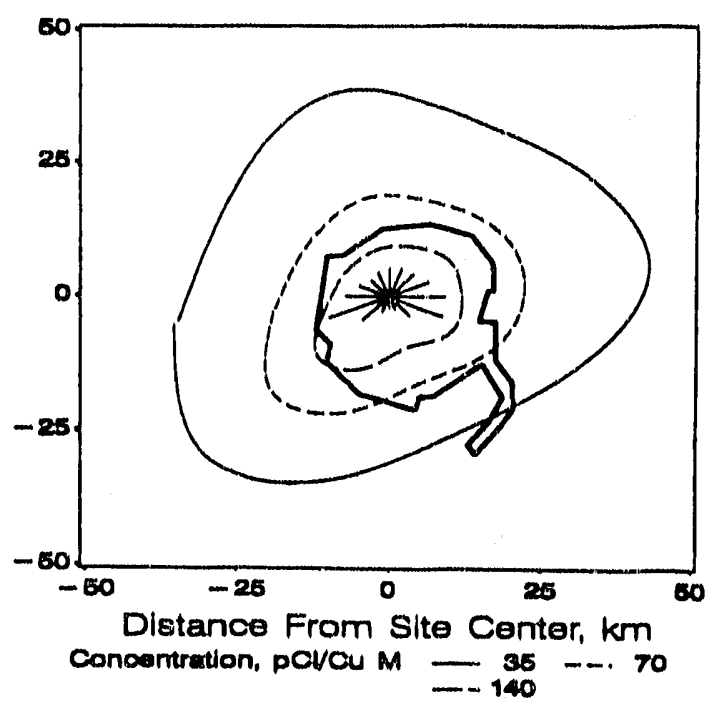

Figure 2.1. The Directional Distribution of Tritlated Water Vapor in the Vicinity of SRS (1982-1986 Data). The Windrose, at the Center, is In Relative Units. The Longest "Petal" is 31.2 km/day

is mirrored by the increased frequency of wind blowing in theso directions. While there is some variation in the wind direction frequency between years and between seasons within years, the annual distribution of tritium transported from SRS is almost equal in each direction.

Figure 2.2 shows the annual average air concentration at each monitoring station during the 5-yr period from 1982 to 1986 plotted against the distance from the center of the site. The lower, solid line is drawn through the annual average concentrations while the upper dashed line represents the level at each distance which is calculated to lie above $95 \%$ of the measured maximums.

When plotted on logarithmic coordinates, the relationship between distance from the center of SRS and the air concentration is approximately a straight line. The tritium 
concentration for a set of measurements taken over a speciflc period of time can be characterized (I.e. approximately reproduced) by the concentration at any arbitrary point on this line and the slope of the line.

The straight line drawn on Figure 2.2 can be characterized by an air concentration of $65.7 \mathrm{pCl} / \mathrm{m}^{3}$ at $20 \mathrm{~km}$ and a slope of -0.76 . The $20-\mathrm{km}$ distance is outside, but near, the SRS boundary. The negative slope indicates that the concentration is decreasing as the air is sampled at increasing distances from SRS. The releases for all the years when data were collected can be characterized in this way and compared to each other or to factors which are thought to have an influence on the concentrations measured in a particular year.

Figure 2.3 illustrates the varlation from 1963 to 1988. The variation in slope is related to variation in the meteorological conditions under which the tritium releases took place.

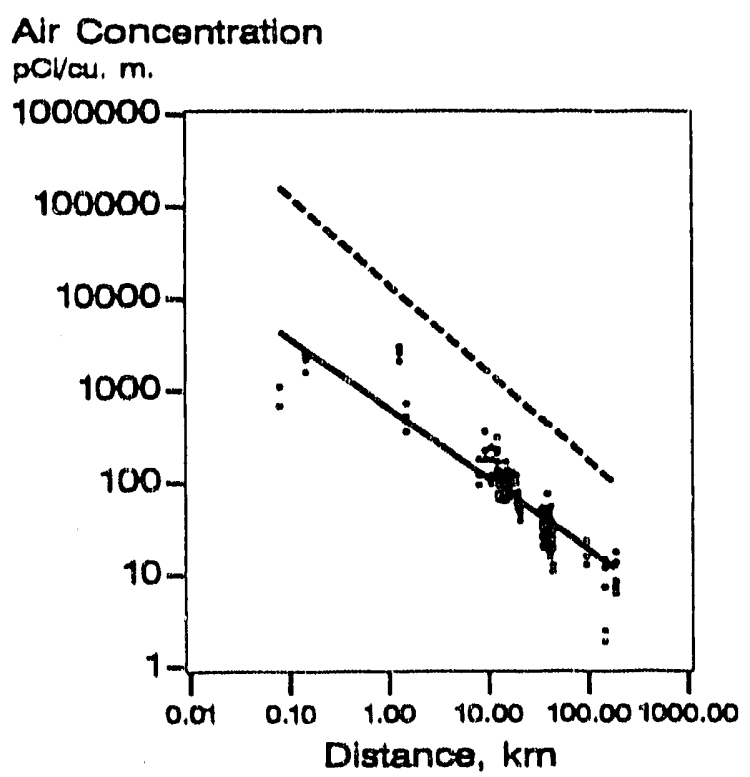

Figure 2.2. The Decrease in /iverage (1982. 1986) and Maximum (All Avallable Data) Air Tritiated Water Concentration with Distance from the Center of SRS

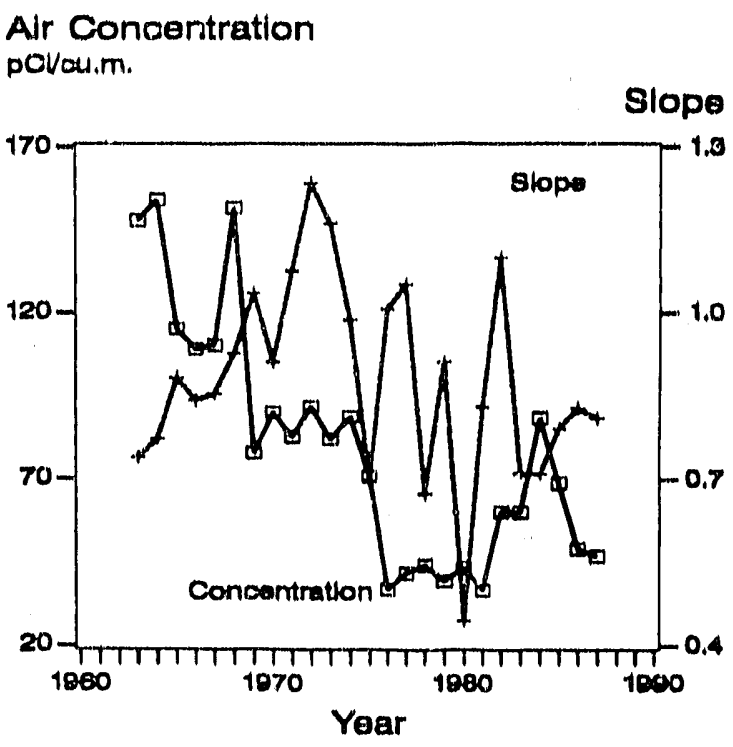

Figure 2.3. The Year-to-Year Variation in Slope and the Characteristic Concentration of Air Water Vapor Tritlum at $20 \mathrm{~km}$

This is not as simple as annual variation caused by differences in wind speed or rainfall. Tritium releases are not uniform throughout the year, and variation can be the result of the coincidence of meteorological conditions and release rates during the year as well as ditierences in the average meteorological conditions. The slope of the air water vapor tritium concentration with distance relationship calculated with one year's data is probably the best characterization of the tritium decrease with distance for any single year. However, the slope calculated from data for a longer period of time is more likely to be representative of the average SRS situation and is probably a betterindicator of the diffusion climatology of SRS.

As previously described, when a gas, such as tritlated water, moves from a release point and is mixed through a constant height of the atmosphere, the concentration varies inversely with distance from the point, which is the 
same as the slope of the relatlonship having the value of -1.0 . The average alope of the concentration versus distance relationship for all the tritiated water vapor samples is -0.76 . This means that the concentration decreases more slowly than would be expected from simple passive radial diffusion. A factor that could account for the smaller slope is that tritiated water is released from elevated stacks and the center of the plume does not reach the ground for some distance downwind of the source. This counteracts the effect of mixing throughout a larger air mass as the plume moves downwind.

The concentration of tritiated water at the reference distance also varies greatly from year to year. Meteorological differences can affect this parameter, but the largest effect is likely due to differences in the amount of tritium released during the particular year. Figure 2.4 shows the variation in air tritiated water concentration plotted against the total tritium released to the atmosphere during the year. It is apparent that the air tritiated water concentration can be better esiimated if the tritium released is taken into account.

As documented in the preceding chapter, most of the releases to the atmosphere come from the tritium production area, the chemical separations plant, or the reactor areas. Tritium from the reactor and chemical separation areas is almost entirely in the form of tritiated water vapor. Historically tritiurn from the tritium production area has been primarily, but not totally, in the form of tritiated hydrogen. Since the sampling monitors collect tritiated water only, the air concentrations measured should respond to the releases of the separations and reactor areas plus some fraction of the tritium production area reloases.

The fraction of tritlated water in the tritlum production area has been measured for only

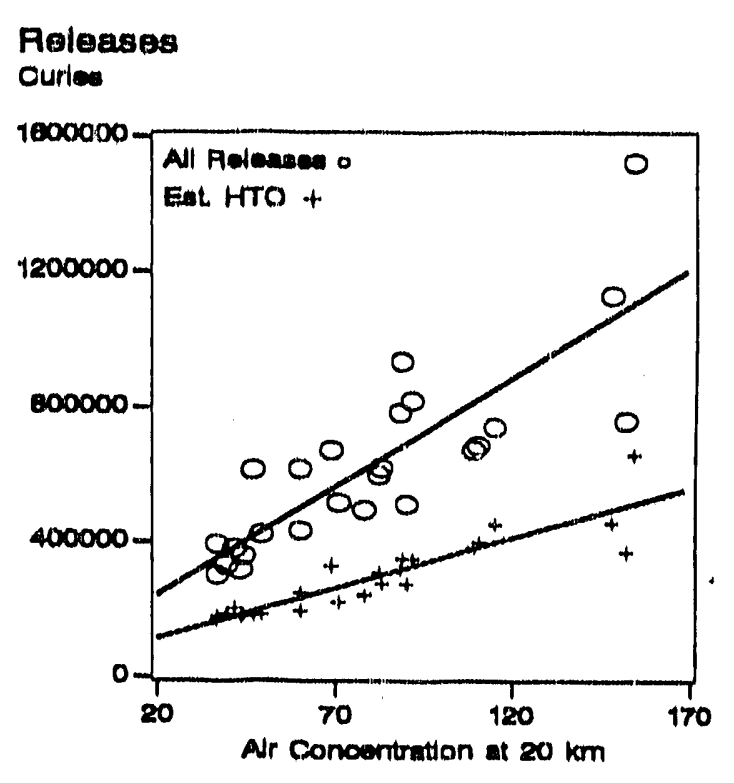

Figure 2.4. The Effect of Releases on the Concentration of Tritlated Air Water Vapor.

a few years and varies from year to year. However, an attempt was made to determine the average fraction of tritlated water in the releases of the tritlum production area for the period of measurements of atmospheric tritiated water. The characteristic tritlated water vapor concentration at $20 \mathrm{~km}$ was plotted against an estimate of the tritiated water vapor released, the releases to all other areas, plus some fraction of the releases of the tritium production area. The values are closer to a straight line through the data inan when plotted against the total releases.

The fraction of tritlated water vapor coming from the separations area can be estimated by plotting different values and choosing the points closest to the line. This can be done more accurately by using statistical techniques. The best value determined by statistical regression is that $15 \%$ of the tritlum released from the separations areas was in the form of tritlated water vapor. The second set of points and the lower straight line in 
Figure 2.4 are the results of these ralculations. The fraction of tritlated water released is close to the value of $16 \%$ that was determined when the chemical forms of tritium were measured during a few years experlencing no large, unplanned tritlated hydrogen releases. However, measurements of tritlum forms during a more recent 5-yr period which included unplanned releases, suggest that the average for those years was nearer $35 \%$.

From this analysis it is evident that the major factors determining the annual average tritlated water vapor concentration of the atmosphere around SRS are the distance from the source, the wind direction, and the amount of tritlum released. The height of the atmosphere through which the release is mixed and the wind speed also affect the concentration. Although the variation in the annual average values of these factors is not great, it may explain some of the variation in the measured concentrations not accounted for by distance from the site and the quantity of tritlum released in a given year. It appears reasonable to conclude that the iransport of tritlated water vapor in the atmosphere is well understood under SRS conditions and estimates made for dose calculations should be more than adequate.

\section{Deposition of Tritlum in Rainwater}

Deposition of tritlum in rainfall can be the result of two processes, rainout and washout. Rainout involves the incorporation of tritium in precipitation as it forms in clouds away from the earth's surface. Washout occurs when precipitation falling from the cloud passes through air containing tritium. Washout of tritlum from air that has recelved tritlum from facillity stacks or evaporation from seepage basins is the process that is most important in the vicinity of SRS.

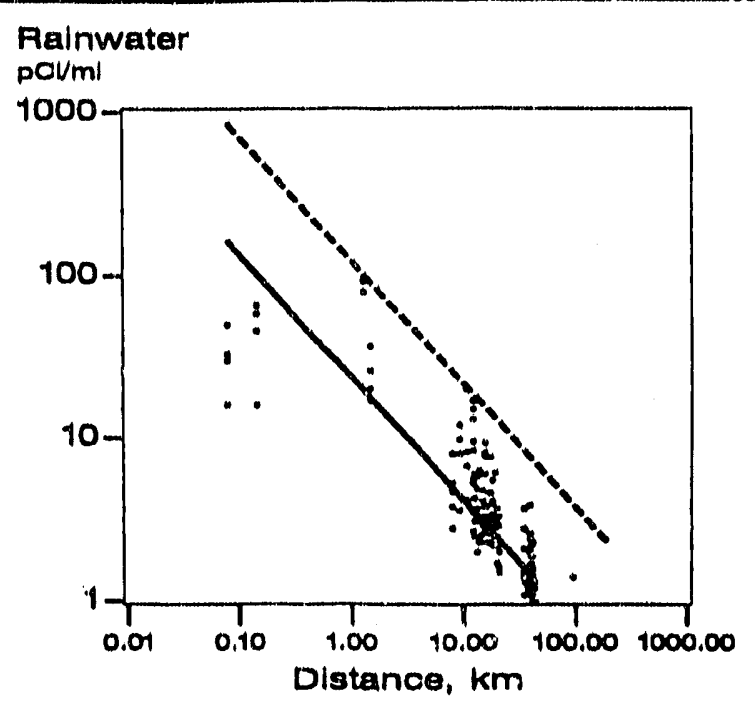

Figure 2.5. Variation of Average (1982. 1986) and Maximum (All Avallable Data) Tritium Concentrations in Rainwater with Distance from the Center of SRS

Rainfall is collected and analyzed for tritiurn at most of the air monitoring locations. If rainfall tritium is derived from the washout of air tritiated water vapor, the tritlum content of the collected rainwater decreases with distance from the site in the same manner as tritiated water vapor and can be approximated by a straight line when plotted logarithmically (Figure 2.5). The slope of the line for the same 5 -yr period used in Figure 2.1 is -0.76 , which is identical to the slope of the alr concentration. As indicated by Figure 2.6, there is gonerally a close correlation between the air concentration of tritiated water vapor and the rainwater concentration.

If air water vapor is the source of rainwater tritium, the tritium content of the rainwater can be no greater than the concentration in the atmospheric water. However, it is possible that the raindrops have not come intis equilibrium with the atmospheric water vapor in the air they are falling through and have a lower concentration. To determine the 


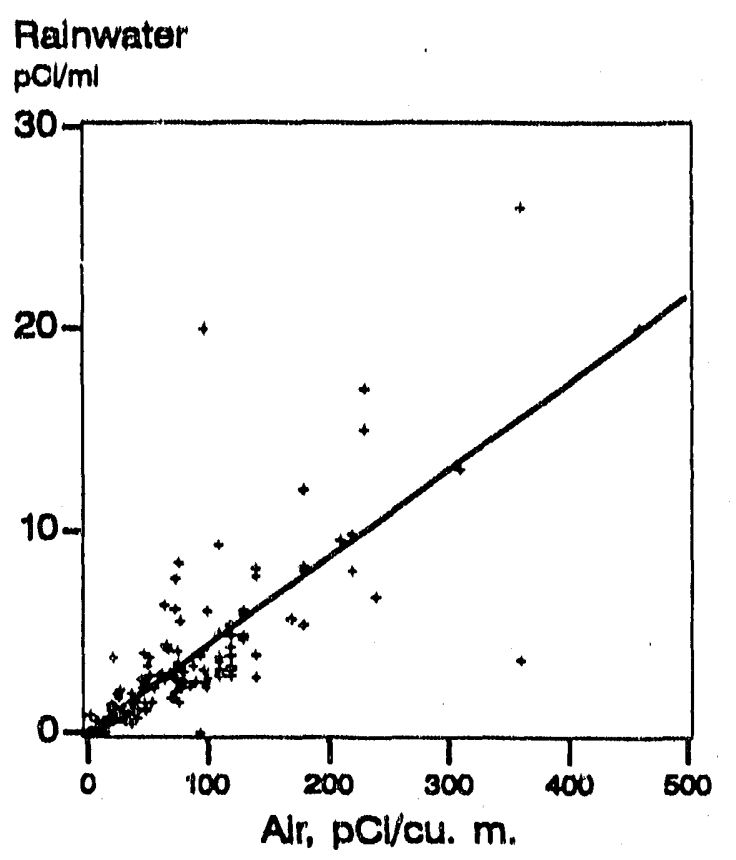

Figure 2.6. The Annual Average Concentration of Tritium in Rainwater Compared to the Concentration in the Air at Each Monitoring Location (1982-1986)

concentration of tritium in the atmospheric water vapor, the concentration in the air must be divided by the amount of water in the air. For example, if the concentration of tritium is $10 \mathrm{pCl} / \mathrm{m}^{3}$ and the humidity is $5 \mathrm{~mL} / \mathrm{m}^{3}$ then the alr water would have a concentration of $2 \mathrm{pCl} / \mathrm{mL}$.

The average equilibrium and its variation from year to year can be determined independently of the variation caused by the decrease in concentration with distance by taking the ratios of the concentrations of air water and rainwater at $20 \mathrm{~km}$. Analysis shows that there is considerable variation between years, with the maximum of $56 \%$ of equillibriurn, a minimum of $20 \%$, and an average of $39 \%$.

Figure 2.7 shows the spatial variation of rainfall deposition around SRS. Like the air tritium concentration, the rainwater concentration is centered arcund SRS. However, the distribution is not clrcular; there is a pronounced higher concentration area in the southwest direction. Figure 2.8 illustrates this distribution in another way. The alr water vapor concentration and rainwater concentration estimated at $20 \mathrm{~km}$ from the site center are plotted for 12 locations around the plant where two or mare sampling stations are located on a line drawn through them and the center of the site. It is evident from this figure that there is a high correspondence between the two distributions, with a peak in the southwestern direction. However, the relative size of the peak in rainwater is a third larger than the peak concentration of tritiated water vapor. For this reason, the rainwater distribution appears less circular than the air concentration distribution.

Some of the difference between rainwater and air water vapor concentrations can be most easily explained by considering the difference in the way the concentrations are measured. Air tritiated watervapor is reported as an averaged sample collected over a 2-week period. The rainwater is collected

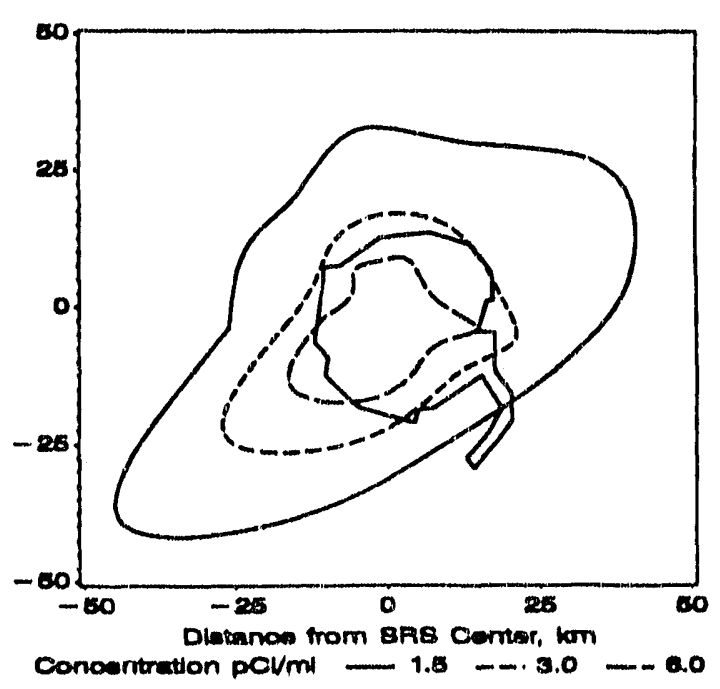

Figure 2.7. The Distribution of Tritium in Rainwater Around SRS (1982-1986) 


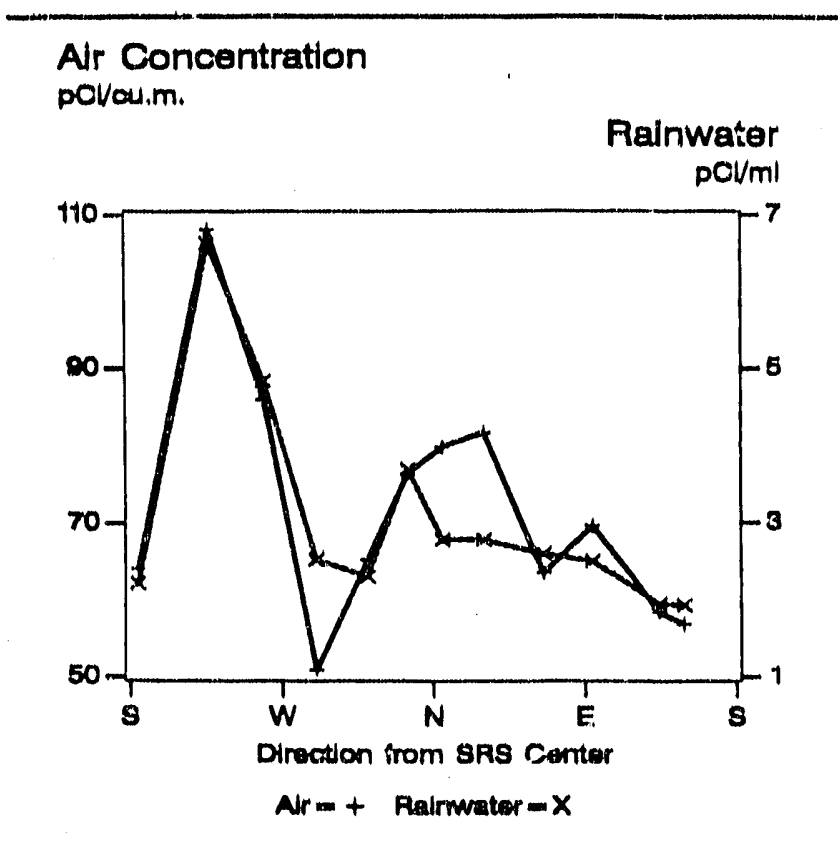

Figure 2.8. A Comparison of the Concentration of Tritium in Alr and Rainwater in Different Directions from the Center of SRS

over the same perlod, but rainfall takes place during only a small part of this period. Thus the rainwater concentration is the result of the air concentration during a small part of the measurement period. This is one reason for the difference in the slopes of the decreasing concentration with distance. When rain is falling, tritlum is being removed from the air, and the concentration falls more rapidly with distance. The air concentration decrease is most affected by the majority of the time when rainfall is not falling and the concentration is not being decreased by rainout.

It is possible that the differences in the characteristics of storm intensity and type may explain the difference between the distribution of tritium in rainwater and air water vapor around the plant (Chamberlain and Eggleton 1964). If rainfall coming from a particular direction is characteristically lighter than the rainfall from other directions, the air concentration during the rainfall will decrease less rapidly in that direction and, therefore, so will the tritium concentration in the rainwater. Higher than average air tritlum concentrations, and correspondingly higher rainwater concentrations, may also be caused by any combination of higher wind speed and lower lateral spreading of the tritlum plume.

A higher concentration in rainwater in a particular direction from the plant center does not necessarlly result in a greater deposition of tritium to the ground. If the high concentration is caused by a low rainfall rate, the amount of tritium reaching the surface could actually be less than the deposition in a direction having low concentration but high rainfall.

From this analysis, it is evident that the most important factor affecting the distribution of tritium in precipitation in the vicinity of SRS is the air water vapor concentration. The average annual rainwatertritium concentration can be estimated to within $\pm 50 \%$ by assuming that the rainwater concentration is $39 \%$ of the measuredair water concentration. An estimate of the total tritium deposition from rainfall can best be made by averaging the results of the rain gage network, as will be done in a later section describing SRS tritlum transport.

\section{Soll Tritium}

The tritium content of the soil is the result of the interaction of a number of processes which transport tritium to or from the soll. The primary source of tritium, other than in areas such as seepage basins, is the atmosphere. Atmospheric releases reach the soll by rainout of tritiated water, deposition of tritlated water vapor (Garland and Cox 1980), ar,d deposition of tritlated hydrogen gas (Murphy et al. 1976, McFarlane et al. 1978, Sweet and Murphy 1981, and Dunstall et al. 1985). 
After deposition, tritiated water vapor is exchanged with the water in the soil and becomes part of the water in the soil pore space. Tritiated hydrogen entering the soil atmosphere is oxidized to tritiated water by microorganisms living in the soil (McFarlane et al. 1978, Sweet and Murphy 1981, and Failon 1982a and b). The tritiated water deposited by any of these processes moves with the bulk of the soil water by miscible displacement as it infiltrates deeper into the soil. While the soil water tritium will drain from the soil surface under any circumstances, it is most rapidly transported as rainfall infiltrating from above displaces the water below it.

Water is also absorbed by the roots of vegetation and reenters the atmosphere hy transpiration from the plants (Belot et al. 1988, Foerstel et al. 1988, and Wiener et al. 1988). A small fraction of the tritium cilso becomes incorporated in the soil organic matter. Figure 2.9 illustrates the major paths of tritium movement in SRS soils in those areas not directly exposed to liquid tritium releases.

Routine measurements are not made of soil tritium because the soil tritium content is accounted for in the vegetation tritium concentration, which is measured. The vegetation tritiated water comies from absorption of soil water.

Soil tritium concentrations have been measured as part of special programs to study this part of the tritium cycle. The results of measurements made by Sweet in 1979 and 1980 (Sweet and Murphy 1981 and 1984) indicated that the tritium content in soil water decreased with distance from the site center. The average concentrations, as shown in Figure 2.10, are similar to those found in rainwater. Each point in this figure is the average of single $60-\mathrm{cm}$ cores of soll taken at different locations.

Depth profiles of soil water tritium concentrations for these same locations show a great deal of variability. In many of the profiles, bands of higher tritium concentration are separated by soil volumes with lower concentrations. Figure 2.11 shows the concentrations for two sites, located about 1 $\mathrm{km}$ from the center of SRS. The distribution of tritium is very different at the two locations even though both are near the center of SRS. The differences in these two profiles can be explained by processes that transport tritium to the soil. The concentration of tritium in the rainwater depends on whether the rain falls through the tritium plume as it falls to a particular site. If the site is downwind from a tritium source, the concentration will be higher than if the site is upwind of the same source.

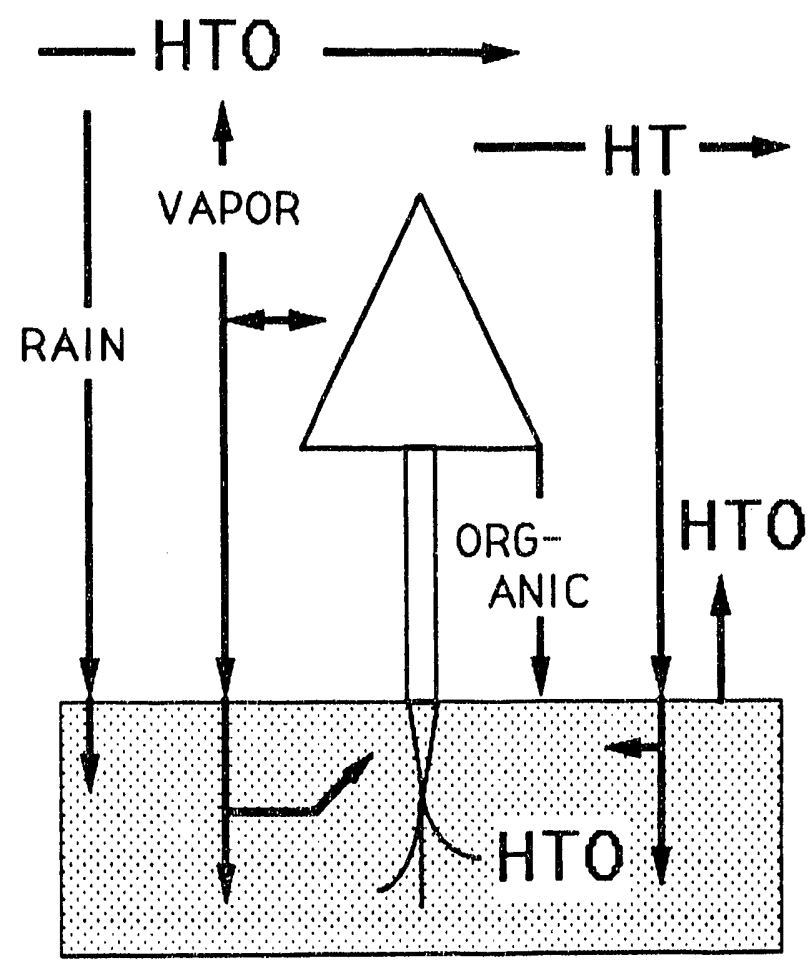

Figure 2.9. The Major Paths of Tritium Transport in the Soil 


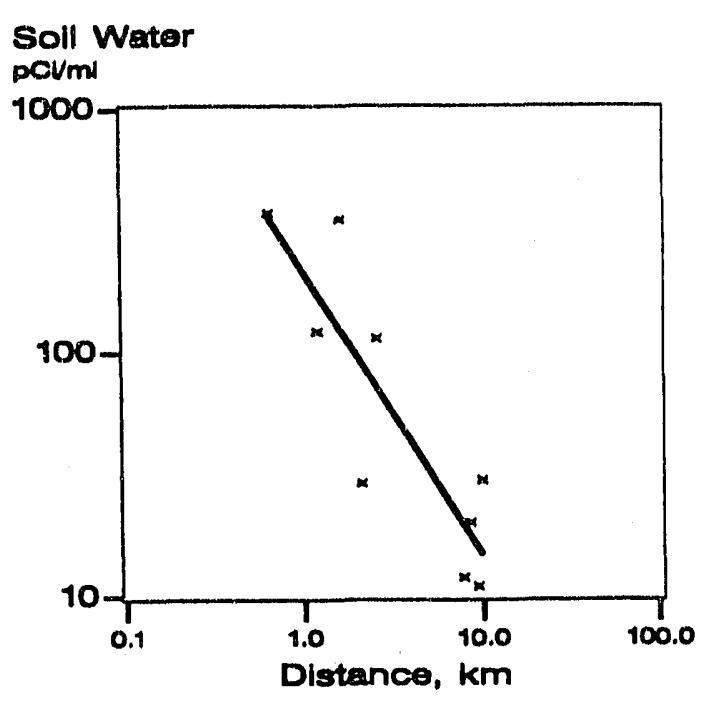

Figure 2.10. Soil Water Tritium Concentrations at Various Distances from the Center of SRS. Grab Samples Taken in 1979.

In addition, between rainfall events, tritium will enter the soil by deposition of tritiated water vapor and hydrogen. The amount of deposition will, as in the case of the rainwater, depend on the direction of the wind and the amount of tritium being released. In this way, soil water that is from rainwater with a higher-thanaverage tritium concentration, or soil water that has been exposed to deposition when it was near the soil surface, is displaced by later rainfall that has a low tritium concentration.

The pattern found at Site 2, shown in Figure 2.11, could be explained by two periods of higher-than-average exposure separated by rainfall with a lower tritium concentration. The probability that deposition is the source of the higher tritiated water concentration at the surface is confirmed by higher-than-average concentrations in the forest floor litter and the leaves of surrounding trees during sampling of this soil profile. The profile at Site 1 has a much lower soil water tritium content, which can be explained by the site not having been downwind of a source for some time before the sample was taken.

Tritium is also found in the organic component of the soil. As a form of hydrogen, it is a constituent of the organic material. Table 2.1 shows the average tritium content of the water and organic fraction of the soil and forest floor (the layer of organic litter on the soil surface). Estimates of the tritium concentration of atmospheric water and rainwater, discussed earlier in this chapter, are also listed for comparison. The large variation in the values of individual samples is indicated by the comparatively large standard deviations of the sample values shown in parentheses.

The mean soil water concentration is close to the estimated rainwater concentration and below the air vapor concentration, which is consistent with the previous measurements of concentrations in the soil water profiles.

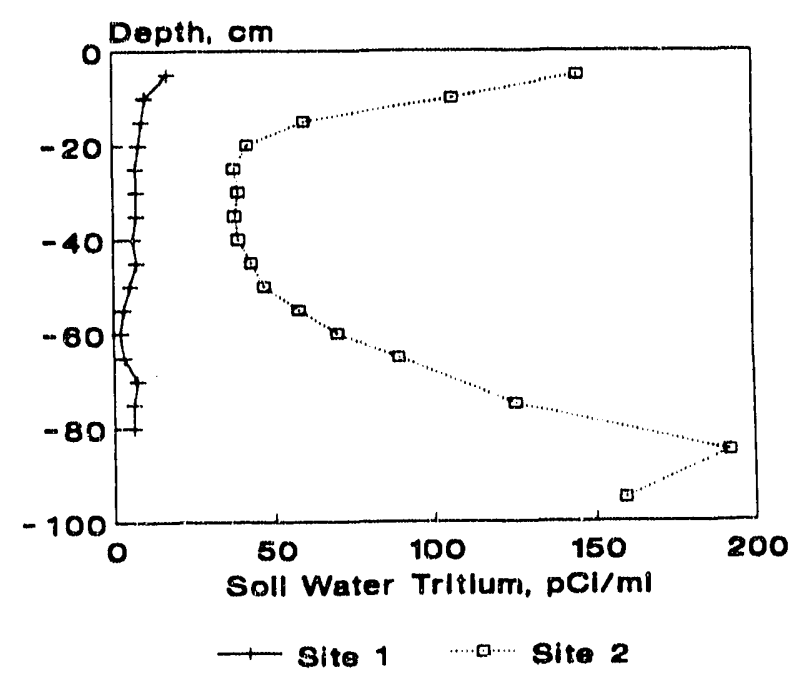

Figure 2.11. Tritiated Water Depth Profiles from Two Locations at the Same Distance from the Center of SRS but with Different Exposure Histories 
The organic tritium concentration is higher than even the concentration of atmospheric moisture. Since all prior investigations with ecological systems indicate that accumulation or concentration of tritium in any part of the environment is very unlikely, there must be another source for the excess tritium in the soil. The high tritium concentration in the forest floor litter suggests that the source of this tritium is from the vegetation growing above the soil, which is also the source of the organic matter. The reason for the higherthan-expected tritium concentration will be discussed in the following section on tritium in vegetation.

The results of these studies show that the average tritium concentration of the soil water is similar to the tritium content of rainwater and will rarely, if ever, exceed the tritium concentration of the tritiated water vapor in the atmosphere.

\section{Tritium Concentration in Vegetation}

The tritium in vegetation is associated with the moisture in the vegetation and with the

Table 2.1. A Comparison of Tritlum in the Soll and Forest Floor with the Tritlum in Atmospheric Moisture and Rainwater.

\begin{tabular}{|c|c|c|c|}
\hline & $\begin{array}{l}\text { Water } \\
\text { pcliml }\end{array}$ & $\begin{array}{l}\text { Drganic } \\
\text { DCEl/mE }\end{array}$ & $\begin{array}{l}\text { Number } \\
\text { Samples }\end{array}$ \\
\hline $\begin{array}{l}\text { Soil } \\
\qquad(0.60 \mathrm{~cm})\end{array}$ & $32(41)$ & $263(362)$ & 10 \\
\hline Litter Layer & $369(958)$ & $353(450)$ & 20 \\
\hline $\begin{array}{l}\text { Atmospheric } \\
\text { Water }\end{array}$ & 150 & & \\
\hline Rainwater & 47 & & \\
\hline
\end{tabular}

- Activity in water equivalent units from water collected when sample was burned. organic constituents of the dry material. Figure 2.12 shows the spatial pattern of tritium concentration in the vegetation water near SRS. It is clear that the concentration of tritium decreases with distance from the center of SRS. The isopleths are not as circular as the isopleths of tritiated water vapor in the atmosphere. However, they do not show the pronounced higher concentration area in the southwest direction found in the rainwater tritium isopleth. The decrease in concentration in the southeast direction is somewhat greater than for either rainwater or atmospheric moisture.

In spite of the nonuniformity in the details of the spatial distribution, the general conclusion is that the concentration of tritiated water in the vegetation, like that in the rainwater and air moisture, is nearly the same in all directions. This would be expected from the pattern of annual wind speed and direction at SRS if the source of tritiated water in the vegetation was from the atmosphere. Figure 2.13 illustrates the consistency of the concentration with direction of air flow in another way.

Figure 2.14 indicates that the tritiated water content of the vegetation follows the same general pattern of decrease with distance from the center of SRS as air, soil, and rainwater tritiated water. For the 5-yr period from 1982 to 1986, the characteristic tritiated water concentration of the vegetation at 20 $\mathrm{km}$ is $3.3 \mathrm{pCi} / \mathrm{mL}$ and the slope is -1.01 . The characteristic concentration is close to that of the air moisture and therefore greater than that of the rainwater. The slope is more negative than the slope of either the air moisture or rainwater, indicating that the concentration of tritium in vegetation drops more rapidly with distance from the center of SRS than the concentration of either the rainwater or atmospheric moisture. 


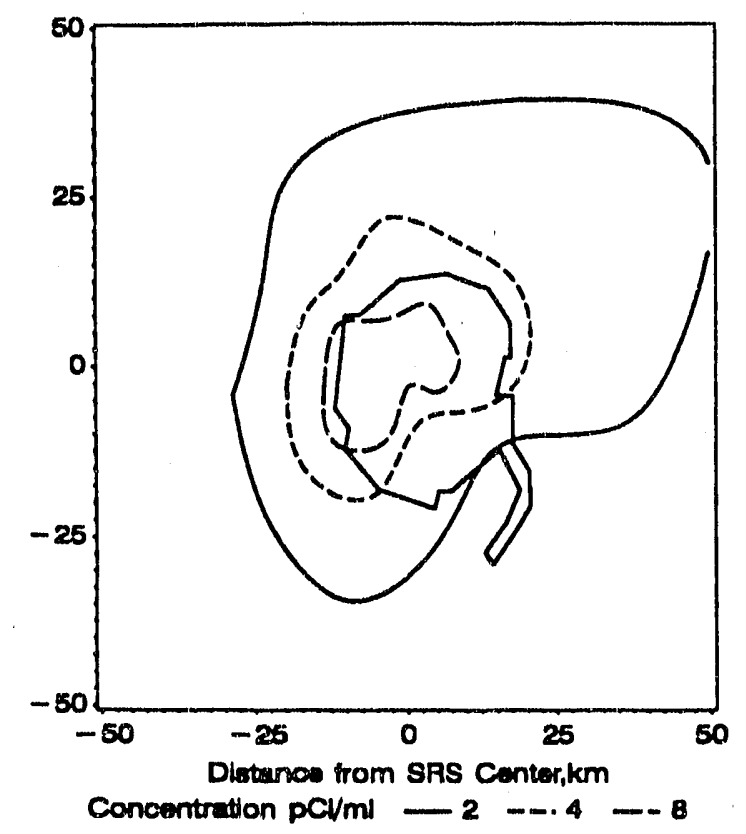

Figure 2.12. The Spatial Distribution of Tritiated Water in Vegetation in the Vicinity of SRS

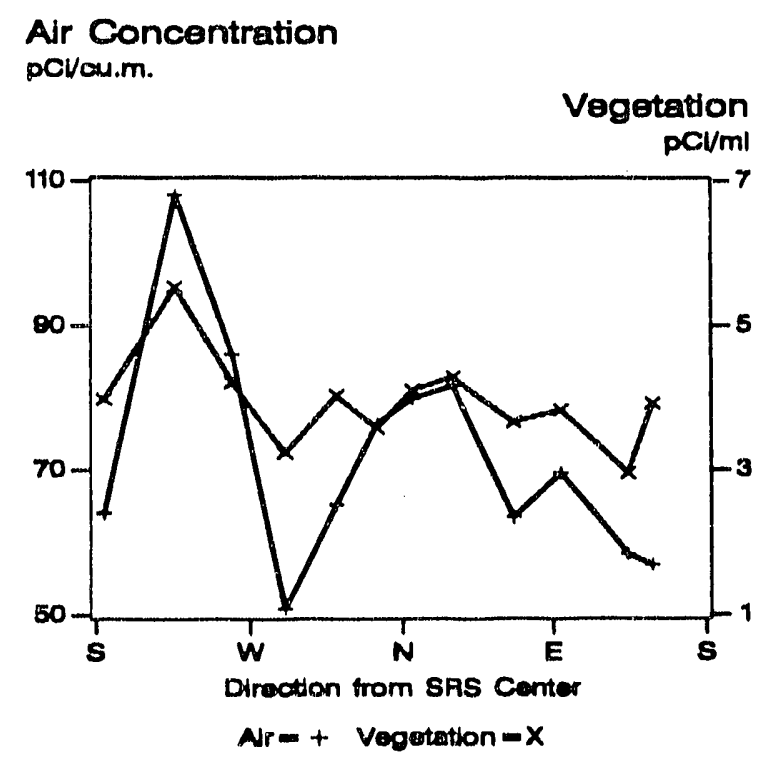

Figure 2.13. A Comparison of the Air Water Vapor and Vegetation Tritium Concentration at $20 \mathrm{~km}$ for Sampling Transects at Various Directions from the Center of SRS (1982-1986)
The tritium concentration of water in the vegetation is the result of a number of processes by which tritiated water enters or leaves vegetation (Raney and Vaadia 1957. Belot et al. 1979, Murphy 1984). Liquid water normally enters the plant from the soil by way of the root and stem systems. Water leaves the plant by evaporation from the leaves. Tritiated water can enter the leaves as vapor and can evaporate from the leaf water.

If the soil water contains tritiated water, the water will enter the roots and move to the leaves at about the same concentration as the soil water. When the tritiated water reaches the leaves, it will evaporate along with the other water from the soil. The rate of evaporation of each type of water, tritiated or normal, depends on the difference in the

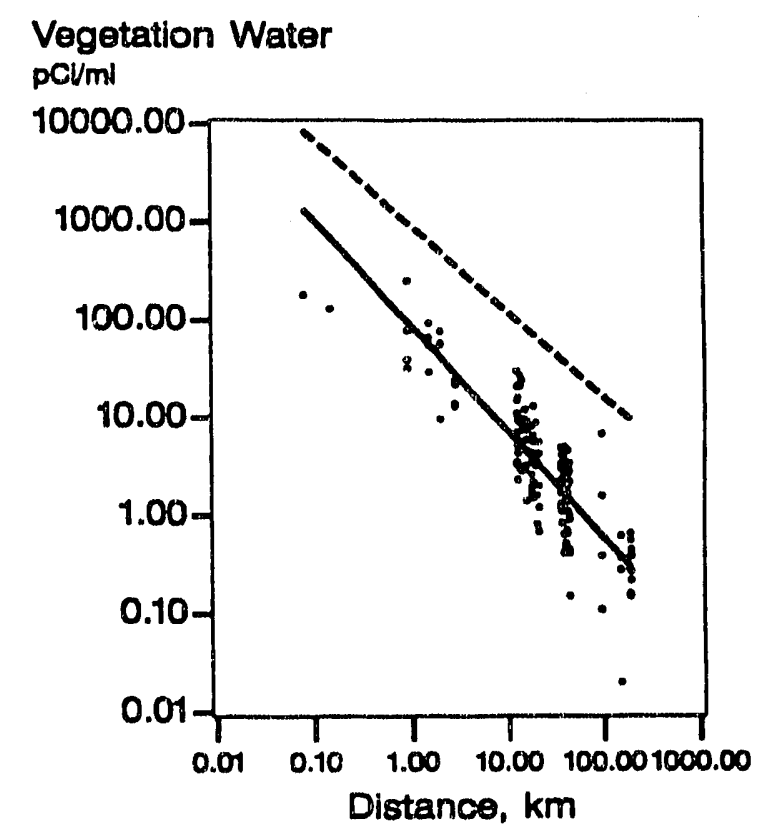

Figure 2.14. The Decrease in Tritiated Water Concentration with Distance from the Center of SRS for Annual Averages (1982-1986) and Maximums (All Avallable Data) 
concentration between the air and the leaf surface for that type of water. The relative rate of evaporation will also depend on the fraction of the water in the leaf of each type of water. If the air has no tritiated water or other water vapor (1.e., the relative humidity of the air is zero), the evaporation of both types of water will be proportional to the fraction of each in the leaves, and the concentration in the leaf will remain the same as that in the soil.

However, if the relative humidity is greater than zero, the difference in the water vapor concentration between the leaf and the air will be less than in the case with zero relative humidity. The evaporation of tritiated water will not change if there is still no tritiated water in the air near the vegetation. In this case the evaporation of tritiated water will be faster, relative to its concentration in the leaf water, than the evaporation of the other water. The higher evaporation of tritiated water will lower the tritiated water concentration in the leaf. The lower concentration will, in turn, lower the evaporation rate of tritiated water. This will continue until a point is reached where the evaporation of tritiated water is equal to the amount of tritiated water being transported from the soil. The result is that the concentration in the leaf will generally be lower than the concentration in the soil water.

The source of tritium in the vegetation can also be tritiated atmospheric water vapor. If the soil water contains no tritiated water, tritium will enter the leaves by diffusion from the air and exchange with the other water in the leaves. If the difference between the water vapor concentration in the atmosphere and the leat is zero $1100 \%$ relative humidity inside the leaf) the tritium will enter the leaf until the concentration in the leat is approximately the same as in the atmospheric moisture. However, if there is a positive difference between the water vapor concentration in the leaves and the air, water will be evaporated from the leaves. When the water evaporates, it will be replaced by soil water pulled up through the roots and the stem. This water will dilute the tritiated water entering from the atmosphere. In time, a steady state tritium concentration will become established in the leaf, which will depend on the rate of entrance of tritiated water and evaporation of other water. The result is that the tritium concentration of the leaf water will generally be less than the tritium concentration of the atmospheric source.

As the previous sections of this report have documented, at SRS both the soil and the atmospheric water vapor contain tritiated water. If the source of tritiated water in the soil were from rainfall only, the soil water concentration would be less than the atmospheric water vapor concentration, and the vegetation concentration would be expected to be higher than the soil water concentration but lower than the atmospheric moisture concentration.

However, at SRS there is an additional source of tritiated water in soil. A significant fraction of the tritium releases from SRS has been in the form of tritiated hydrogen gas. The tritiated hydrogen is oxidized to tritiated water by the action of soil microorganisms. This results in an increase in the tritiated water concentration of the soil and a relatedincrease in the tritiated water concentration of the vegetation relative to the concentration of the air (Murphy and Pendergast 1979). The magnitude of the relative increase depends on the fraction of the atmospheric tritium that is in the hydrogen gas form. It is possible for this process to cause the concentration of tritiated water in the vegetation to be greater than that in the atmospheric moisture. 


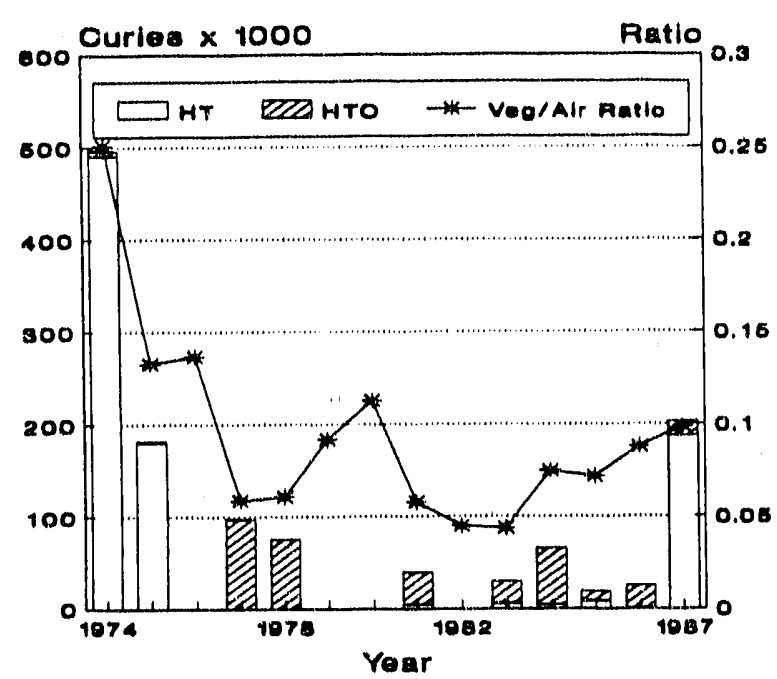

Figure 2.15. The Variation in the Ratio of Vegetation Tritiated Water Concentration to Tritiated Atmospheric Moisture Compared to the Tritium Formand Amount in Inadvertent Releases

Figure 2.15 shows the ratio of vegetation tritiated water to tritiated air moisture. The vegetation is a composite average of all samples taken during a year, including grass, herbs, and tree leaves. During and immediately following years with larger-thanaverage tritiated hydrogen releases to the atmosphere, the tritium concentration is higher in the vegetation than in the air moisture. There is also some suggestion that during and immediately following years with inadvertent releases of tritiated water, the ratio is decreased relative to years having the mixture of tritiated hydrogen and tritiated water characteristic of years with no inadvertent releases.

Long-term monitoring data of organic tritium concentration in vegetation is not available. A few short-term studies provide some information about the concentration of tritium in the organic form in vegetation. Sanders (1976) measured the tritlum content of growth rings in pine trees. $\mathrm{He}$ analyzed rings grown before SRS operation and rings grown during 1960,1965, and 1970 . The results of his measurements are illustrated in Figure 2.16. They show the characteristic decrease in concentration with distance from the center of SRS that is found in the vegetation water. This is expected since the organic matter in the tree rings was produced from carbon dioxide and water in the tree leaves by the process of photosynthesis (Belot et al. 1983).

The synthesis of vegetation organic matter from vegetation water is also the reason for the generally greater concentration of tritium - in the organic fraction of the soll than in the water fraction of the same soil derived from the forest floor litter. The soll water

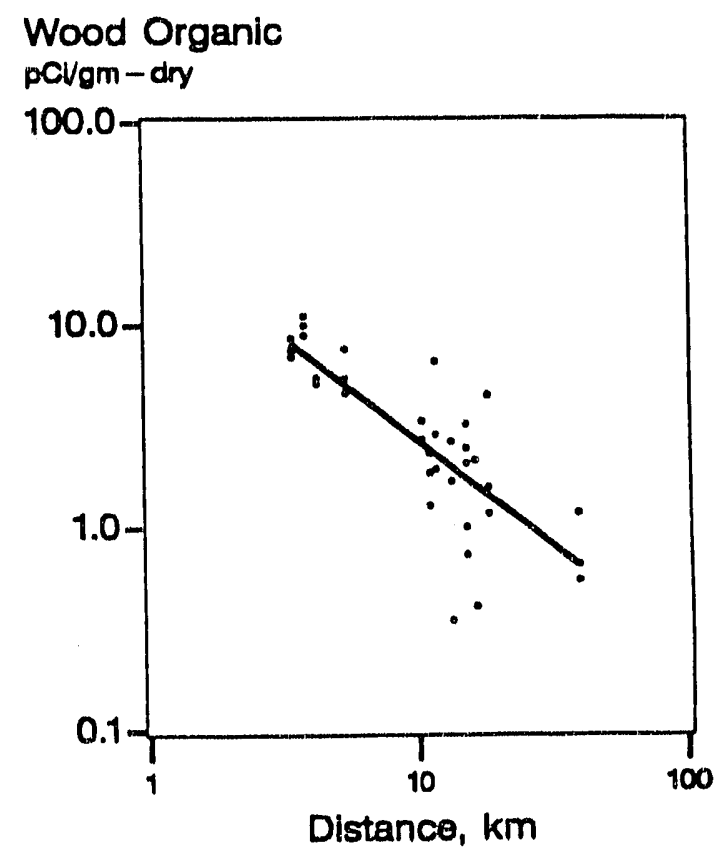

Figure 2.16. The Decrease in the Tritium Concentration of Wood Organic Material with Distance from the Center of SRS 
concentration is derived from the rainfall, which is lower in tritium than the vegetation water.

The mean tritium concentration in the vegetation is the result of the interaction of a number of processes transporting tritium between the environment and the water and organic fractions of the vegetation. Under SRS conditions, the annual average concentration of tritium in the vegetation moisture can vary from $50 \%$ to $250 \%$ of the annual average concentration of the atmospheric moisture. The average for the 5 -yr period from 1982 to 1986 is 0.73 . This is a larger fraction of the air moisture concentration than is normally used in dose assessment models (Anspaugh et al. 1973). However, it is consistent with steady-state theoretical calculations (Murphy 1984).

\section{Tritium in Wildiffe}

Annual hunts are conducted at SRS to control the site deer and hog populations and to reduce animal-automobile accidents. Hunt yieids average around 1000 deer and 100 hogs a year. These animals are monitored for cesium-137 concentration before they are released for consumption by the hunters. The tritium concentration in deer killed in the hunts has been measured on several occasions.

Tritium concentration in deer is similar to that in vegetation in the sense that the concentration is the result of tritium transport to and from the deer through a number of paths. The majority of the water entering the deer is through drinking surface water. A second major source is the water in food eaten by the deer. The water in food is from the moisture in the food and from the water produced by digestion and catabolism (burning for energy) of the food. Water leaves the deer by excretion in urine and feces. Water can also enter or leave the animal in the breathing air and by absorption or excretion from the skin.

The major path by which water leaves the animal is through excretion. The relationship between the volume of water in the deer and the rate of excretion is the major determinant of the turnover time of tritium in the body once the deer has been contaminated. Studies of deer injected with tritiated water indicate that the turnover time is about 6 days. This suggests that deer, like vegetation, respond to the day-to-day changes of tritium in their environment. However, unlike vegetation, deer are mobile and contain water that is the average of the area over which they range.

In 1986 and 1987, a total of 13 deer were monitored for tritiated water concentration of the flesh (Zeigler et al. 1987 and 1988). In addition, 50 deer were monitored in 1966 as part of an intensive study to quantify the tritium in both the water and organic fractions of the flesh (Evans 1969). Figure 2.17 shows the distribution of tritium concentrations in the water of the flesh of the deer that were analyzed. In both cases the tritium concentration peaked at about $20 \mathrm{pCi} / \mathrm{mL}$. The two deer with higher concentrations sampled in 1987 probably have no special significance. As demonstrated by the earlier deer are mobile and contain water that is the average of the area over which they range.

In 1986 and 1987, a total of 13 deer were monitored for tritiated water concentration of the flesh (Zeigler et al. 1987 and 1988). In addition, 50 deer were monitored in 1966 as part of an intensive study to quantify the tritlum in both the water and organic fractions of the flesh (Evans 1969). Figure 2.17 shows the distribution of tritium concentrations in the water of the flesh of deer that were analyzed. 
In both cases the tritium concentration peaked at about $20 \mathrm{pCl} / \mathrm{mL}$. The two deer with higher concentrations sampled in 1987 probably have no special signiflcance. As demonstrated in the earlier parts of this section, air, water, and vegetation concentration of this magnitude have always been present in a small area near the center of SRS.

In 1966, Evans conducted a detailed study of the relationship of tritiated water to the organic fraction of deer. Samples were taken of various organs, and after the water was removed, the organs were burned and the water of combustion compared to the free water in the deer. He found that the tritium content of the deer organs was always near that of the free water. Figure 2.18 illustrates the results. The comparatively low ratio of tritium in fat to tritium in the body water may be the result of the few exchangeable hydrogen sites in these compounds. It has been shown

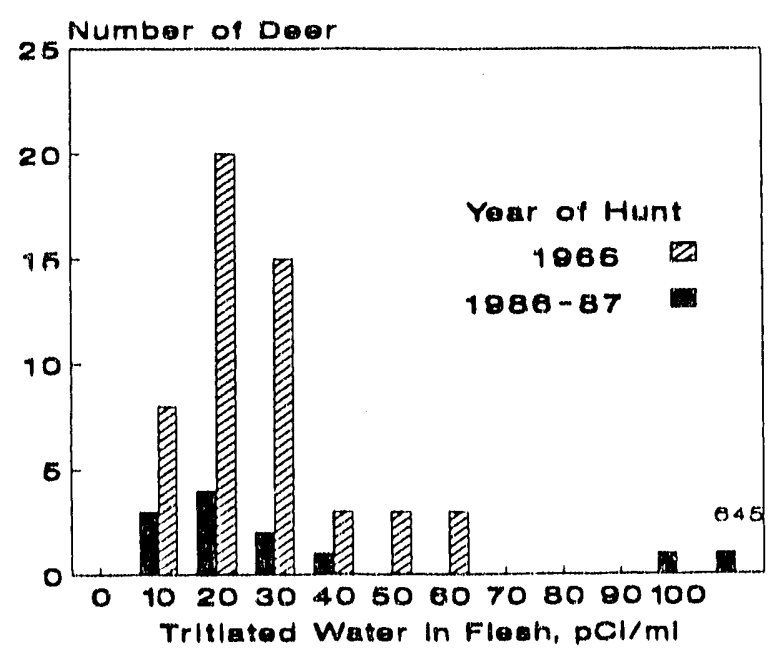

Figure 2.17. The Frequency of Deer Within a Given Range of Tritiated Water Concentration Collected During the Intensive Study in 1966 and During Routine Monitoring in 1986-1987

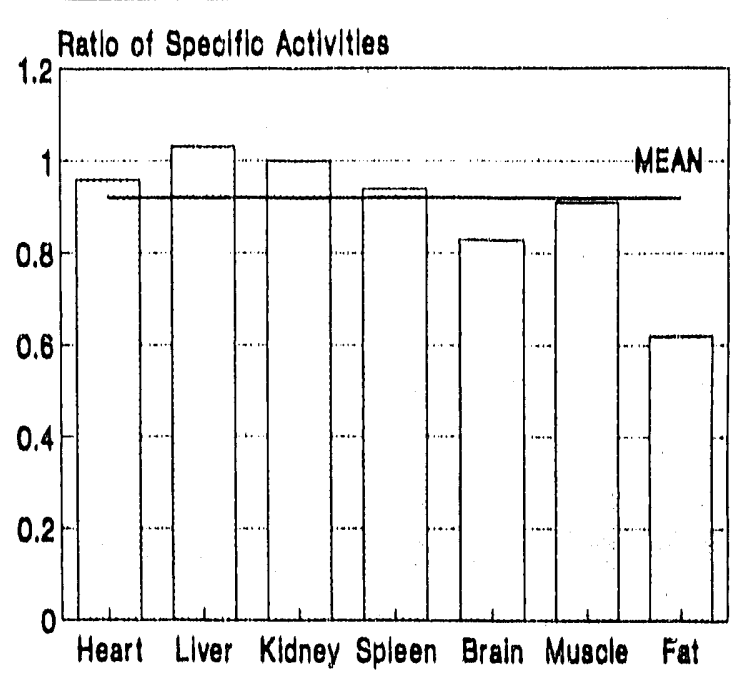

Figure 2.18. The Ratio of Organic Tritlum to Tritiated Water in Individual Organs for Deer Collected During 1966 Hunting Season

that fats and oils have almost the same tritlum content as the fats and oils in the diet of an animal, while other compounds exchange at least a part of their hydrogen with the surrounding water.

The results of these studies indicate that the tritium content of both the water and organic content of deer at SRS reflect the tritium content of the environment around them. This is probably a good indication of what to expect in otheranimals, and particularly in other mamriais such as man.

\section{Tritium in Food}

Tritium is measured in a variety of crops and animal food products grown in the vicinity of SRS. Milk is collected at local farms and from one major milk distributor which gets its milk from the area surrounding SRS. These samples have been taken since the early 1960 s when easy methods for measuring tritium became avallable. Before 1971, the 


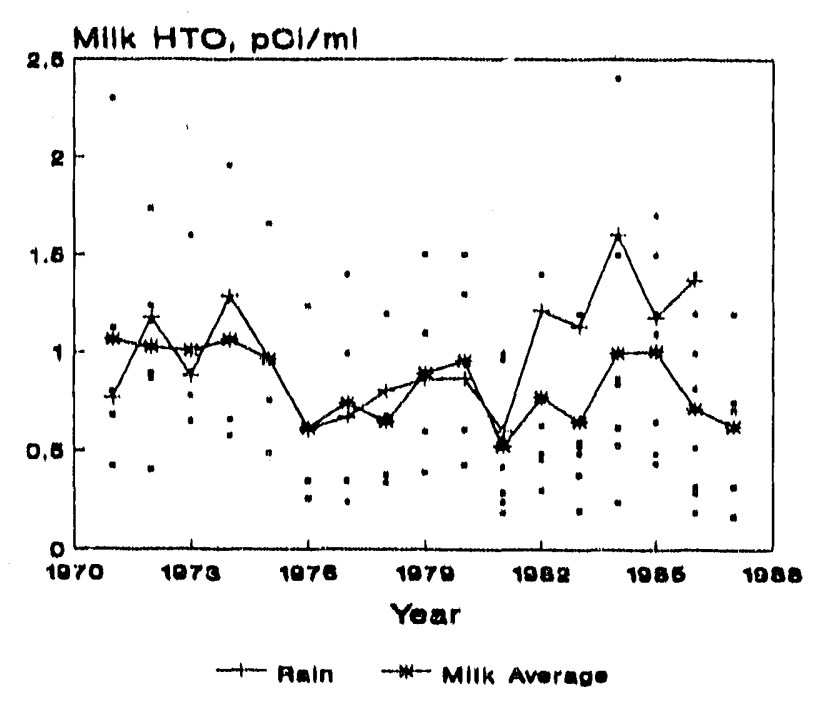

Figure 2.19. The Annual Average Tritium Concentration in Milk Water for Each Dairy or Distrlbutor. The Annual Average of all Distributors and Dairles is Compared to the Annual Average Rainwater Contentration from the Sampling Arc at 40 $\mathrm{km}$ from the Center of SRS

sensitivity of the measurement techniques could resolve only a few of the highest tritium concentrations, and most results were reported as below the detectable limit. Since 1971, detection methods have become more sensitive. All but a few of the lowest measurements are above the detection limits and reliable mean values can be determined.

Figure 2.19 shows the results of the mean tritlated water concentration in milk for each dainy or distributor for each year. The average of all sources and the average rainwater measured at the ring of sampling stations 40 $\mathrm{km}$ frorn the center of SRS are also shown. The tritium concentration in milk water and rainwaterare very similarthroughout the period of measurement.

Four vegetable food types were measured from 1971-1987: collard greens, fruit (plums, apples, or peaches), grains (wheat, rye, or barley), and corn. As described in an earlier section of this report, the water concentration in the aerial parts of plants is determined by both the atmospheric and soll tritlated water concentration. Figure 2.20 shows that the average tritiated water concentration of orop plants is similar to the average concentration of tritlum in air moisture. Because of the scatter in these data, it is impossible to differentlate between the ratios of various crop to air moisture tritium concentrations that are found in the literature. A ratio of 0.5 is used in most dose calculations although a ratio of 0.73 is found in other vegetation at SRS, and equilibrium conditions would imply a ratio of 1.0 .

The tritlated water cencentration of four animal food types were also measured during

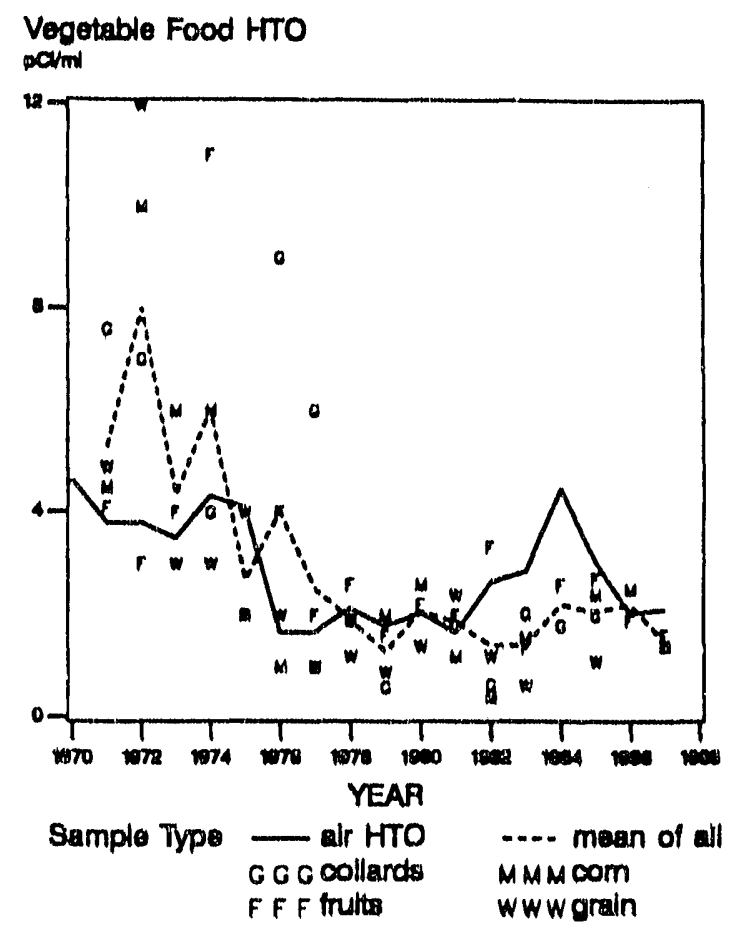

Figure 2.20. Tritium Concentration In the Water of Selected Vegetable Food Grown in the Vicinlty of SRS. The Annual Average of All Foods is Compared to the Annual Average Air Moisture Concentration at an Arc $40 \mathrm{~km}$ From the Center of SRS 


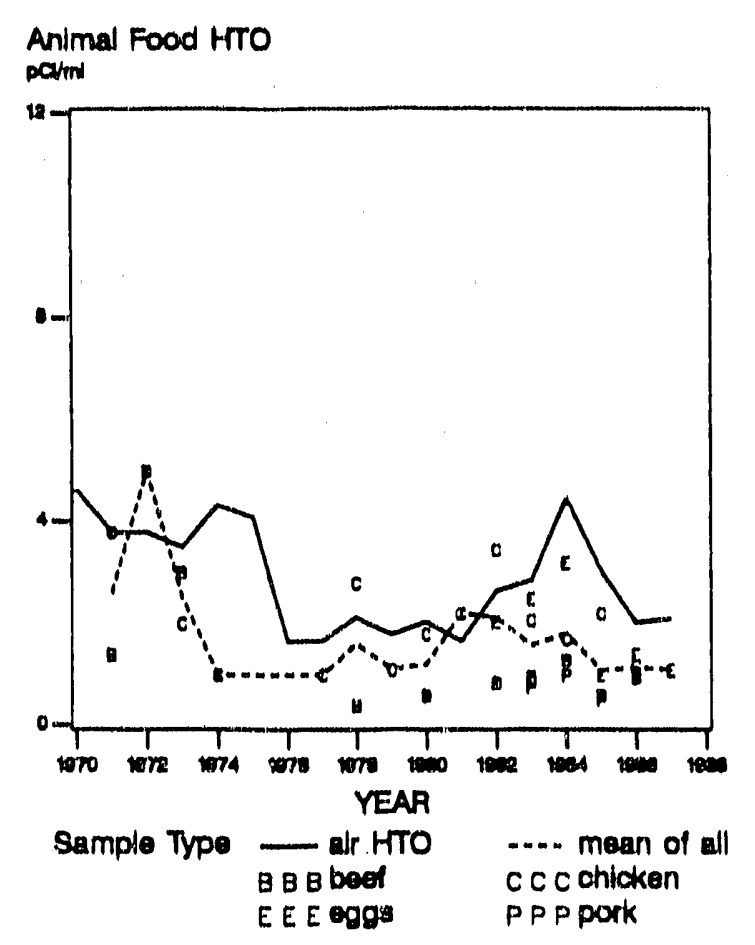

Figure 2.21. The Tritiated Water Concentration of AnImal Foods Collected In the Vicinity of SRS Compared to the Annual Average Tritlum Concentration of Alr Moisure

the same perlod: beef, eggs, chicken, and pork. The mean tritium concentration was similar to the concentration in the air moisture collected at the ring of sampling stations located $40 \mathrm{~km}$ from the center of SRS (Figure 2.21). The results of the measurements of tritium in food in the vicinity of SRS indicate that the concentration in food is very similar to the concentration in environmental water. As in the case of vegetable foods, the small sample size and scatter in the data preclude determining a definitive value of the ratio of tritium concentration in animal and air moisture.

\section{TRITIUM CONCENTRATIONS FROM INAIDVERTENT RELEASES TO THE ATMOSPHERE}

\section{Introduction}

Dispersion of Inadvertent, short-term releases into the atmosphere is affected by the same physical and biological processes that determine the concentration from the chronic releases from normal activities. However, because of the short duration and the reiatively large amount of tritlum released during these periods, the concentrations can be higher and less uniformly distributed than the concentrations due to routine releases.

All unplanned releases enter the environment from a stack (usually the 60-m trittum facility stack). The released material mixes into an increasingly larger volume of the atmosphere as the release moves downwind from the stack. The horizontal and vertical spread of the release depends on the size and intensity of the turbulent eddies and the wind speed. The greater the turbulent spreading and the lower the wind speed, the further the release will spread at any distance from the release point.

At some distance downwind, the edge of the release will spread to the surface of the ground. At this point the tritium will interact with the vegetation, fauna, and soll in the path of the release.

At distances less than $80 \mathrm{~km}$, many of the releases appear to have a Gaussian 
concentration cross sectlon, with a single peak at the center of the path, which slopes to zero concentration on both sides. However, unevenness of the terral 1 and meandering of the wind often cause non-Gausslan patterns of spread.

Further from the release point, the volume of air containing tritlum will grow to a size that interacts with the large-scale weather systems. At this point, the release may split or double back on itself, causing a very complex pattern of dispersion. By this time, however, the tritlum concentration will decrease substantlally.

The first indication that a release is taking place may come from some incident in the separation facility or the reactor facillty, or it may be be detected by the tritlum monitors located in the stacks. Once the release is confirmed, survey teams begin taking fleld samples of air, air moisture, vegetation molsture, soll moisture, surface water, and milk from locations downwind of the release. The location of the sampling points is determined by the path forecast by the SRL WIND system (see Appendix 1 for description) and the access to sample points on roads crossing the path of the plume.

Air sampling capability has increased since 1985 with the development of the sampling apparatus and the capabilities of the TRAC vehicle (see Appendix 1 for description). However, there was no field instrument avallable at the time of the releases reported in this section that could measure air tritium at the concentrations found in the environment. Samples were collected, processed, and later counted. This meant that the air concentration measurements could not be used to determine the centerline (highest concentration) of the release. The sarne was true of vegetation, soll, and surface water samples. However, vegetation, soll, and water samples are easier to collect than air samples and a greater number of samples can be collected and brought back to the laboratory for later analysis. This procedure usually provides the best confirmation of the paths forecast by the WIND system.

The environmental concentrations during and immediately after inadvertent releases are higher than those measured under average releases and result in the highest concentrations found in the environment from SRS operations.

Because of the complex factors vietermining the spread and uptake of tritlum from a short-term release, it is necessary to treat each release as a special case. The following section will describe the characteristics of the 12 inadvertent atmospheric releases that occurred from site startup in 1952 through 1988.

A summary of the tritium concentrations in the environmental samples collected after nine of the largest and best-documented releases will be presented and discussed with the purpose of looking for patterns that allow a general conclusion to be drawn about how tritium interacts with the environment following comparatively large releases of short duration.

\section{Summary of Inadvertent Atmospheric Tritlum Releases}

May 2, 1974. A valve failure resulted in a 473,000 Cl release from a $60 \cdot \mathrm{m}$ stack located in the Separations Area. The release occurred over a 4 -min period beginning at 0755 hours eastern standard time (EST). The tritium form was estimated to be primarly tritiated hydrogen gas with less than $1 \%$ tritlated water. 
At the time of the release, light winds carrled the tritlum in a northeasterly direction (azlmuth $210-2.25 \mathrm{deg}$ ) at 6.4 to $9.7 \mathrm{~km} / \mathrm{hr}$. Cloud cover at Bush Fleld in Augusta, GA, was $90 \%-100 \%$. The atmospheric stablllty was judged to be neutral. The trajectory of the release carrled the tritium north of Columbla, SC, beyond which point it was diffloult to predlot because of complex weather patterns.

Exterisive measurements were made of the tritlated water content of vegetation, solls, and surface water. A single air sample collected about $5 \mathrm{hr}$ after the release had a 30-min average concentration of 390,000 $\mathrm{pCl} / \mathrm{m}^{3}$, of which less than $1 \%$ was in the form of tritlated water. The highest vegetation, surface water, and soll water concentrations were 4630, 10,000 , and $138 \mathrm{pCl} / \mathrm{mL}$, respectively. Milk collected from a beef cow was found to have an elevated tritium concentration of $375 \mathrm{pCl} / \mathrm{mL}$.

December 31, 1975. At 2000 hours EST, $182,000 \mathrm{Cl}$ of tritium gas was released from a stack in the tritium separations area. Ninety percent of the tritium was released in the first $1.5 \mathrm{~min}$. Air samples indicated that $0.6 \%$ of the release was in the form of tritiated water with the rest in the hydrogen form.

The cloud cover was about $30 \%$ and the wind speed $35 \mathrm{~km} / \mathrm{hr}$ at the time of the release. The atmospheric stabillty was neutral. The wind carried the release in an easterly direction (azlmuth 270-289 deg). The trajectory of the release carried the tritlum north of Charleston, SC, where it passed over the ocean between 0500 and 0600 hours on January 1.

Maximum air molsture, surface water, and soil tritium concentrations were 687,27 , and 242. Cl/mL, respectlvely. Air, water, and milk samples collected after the release were within the values routinely rneasured at other times.

March 27, 1981. At approximately 0845 hours EST, $33,000 \mathrm{Cl}$ of tritlum were released to the atmosphere from a separations area processing facllity. The duration of the release was about $2.5 \mathrm{hr}$. Analyses of stack samples taken during the incldent Indlcated that $99.7 \%$ of the tritlum was released as tritlated water vapor.

The sky was sunny during the day, with scattered cumulus clouds forming in the afternoon. The temperature was between $75^{\circ}$ and $80^{\circ} \mathrm{F}$. The surface wind at the time of the release was blowing at $18 \mathrm{~km} / \mathrm{hr}$ toward the east. Later in the day this increased to 21 to $26 \mathrm{~km} / \mathrm{hr}$. The trajectory carried the release northeastward where it crossed the coastline at approximately the North Carolina-South Carollna boundary.

Maximum tritlated water concentrations were 270,9 , and $39 \mathrm{pCl} / \mathrm{mL}$ for vegetation, surface water, and soll water samples, respectively, collected outside the boundary of SRS. A vegetation sample inside the SRS boundary was found to have a tritiated water concentration of $4860 \mathrm{pCl} / \mathrm{mL}$. Milk and foodstuff samples were within the values measured at other times.

July 16, 1983. At 2213 hours EST, $56,000 \mathrm{Cl}$ of tritlum were released from the tritium separations area. The release took place over a period of approximately $3 \mathrm{~min}$. Analysis of samples of the released gases indicated that about $1 \%$ of the release was tritiated water vapor and the remaining $99 \%$ was in the hydrogeri form.

The sky was $75 \%$ to $100 \%$ covered with clouds at the time of the release, with rain and 
thundershowers early in the evening. The cloud cover dissipated by 0200 hours of the following day. Surface winds were $18 \mathrm{~km} / \mathrm{hr}$ around the time of the release, blowing toward the nurtheast. The trajectory carried the release offishore north of Charleston, SC.

Vegetation, surface water, and rainwater tritlum concentrations were 150,23 , and 18 $\mathrm{pCl} / \mathrm{mL}$, respectively. Milk and air moisture samples were within the concentration range routinely measured in samples in the vicinity of SRS.

March 23, 1984. At 0440 EST, a leak in a process line led to a release of $7500 \mathrm{Cl}$ from a stack in a separation facility. The majority of the release occurred in the fl st $2 \mathrm{hr}$ and 20 $\mathrm{min}$. Approximately $70 \%$ of the release was in the tritlated water vapor form; the remaining $30 \%$ was in the hydrogen form.

During the morning of the release, the winds were blowing toward the east-southeast (azimuth of $280 \mathrm{deg}$ ) at $21 \mathrm{~km} / \mathrm{hr}$. Skles were clear with a $10 \%$ cloud cover. There was a low-level inversion at the time of the release, Indicating stable atmospheric conditions. The inversion dissipated by 0930 hours, and unstable atmospheric condition prevailed from that time forward. The release trajectory moved to the south-southeast for the first $2 \mathrm{hr}$ then swung to the southeast for the next $8 \mathrm{hr}$ before turning to the northeast and moving over the ocean near Charleston, SC.

Maximum vegetation and surface water tritiated water concentrations were 1380 and $120 \mathrm{pCl} / \mathrm{mL}$, respectively. Two samplingteams measured tritium forms in atmospheric samples. The highest concentration was found to be $6170 \mathrm{pCl} / \mathrm{m}^{3}$, with about $90 \%$ of the sample in the water vapor form. The maximum tritium concentration in milk was $69 \mathrm{pCi} / \mathrm{mL}$.
September 2-7, 1984. Beginning at 1900 hours EST, a release of $57,900 \mathrm{Cl}$ of tritlum occurred from a stack in the Separations Area. Approximately $43,800 \mathrm{Cl}$ were released in the first $5 \mathrm{hr}$ of the period, with the remainder slowly entering the environment over the next 5 days. The release consisted of $99 \%$ tritiated water vapor.

At the beginning of the release, the wind was blowing in the direction of Alken, SC (azimuth $170 \mathrm{deg}$ ). The wind speed remained steady at $16 \mathrm{~km} / \mathrm{hr}$ during the first $5 \mathrm{hr}$ after the release. The wind later shifted toward the east carrying the tritium near Lexington, SC. Temperature profiles from the instruments on the WJBF television tower indicated an inversion existed, and the stable atmospheric conditions kept the plume in a narrow band as it moved away from the source.

Sampling teams measured atmospheric tritium along the path of the release. Becaus $\theta$ the release path was narrow, it was difficult to obtain samples in the center of the release. The highest tritium concentration measured was $15871 \mathrm{pCl} / \mathrm{m}^{3}$ at Blythewood, SC, about $124 \mathrm{~km}$ from the release source. Vegetation samples from this location indicated that this may have been very close to the center of the path. Vegetation and milk samples were collected by SRS and South Carolina Department of Health and Environmental Control (SCDHEC) sampling teams. The highest concentration of tritiated water in vegetation was $9800 \mathrm{pCl} / \mathrm{mL}$, measured at a location $40 \mathrm{~km}$ from the release point. The highest concentration near the SRS boundary was $2500 \mathrm{pCl} / \mathrm{mL}$. The highest concentration found in milk was $47 \mathrm{pCl} / \mathrm{mL}$ near Windsor, SC.

January 31, 1985. A total of $9285 \mathrm{Cl}$ of tritium was released from the stack of the tritium 
separations area. The release took place from 1400 to 1700 hours EST. The majorlty of the tritium, $7400 \mathrm{Cl}$, was released in the first $15 \mathrm{~min}$. Of the total release, $54 \%$ was in the tritlated water form and the remaining $46 \%$ was in the hydrogen form.

At the time of the release, the wind was blowing toward the north-northeast at $21 \mathrm{~km} / \mathrm{hr}$. The cloud cover at Bush Field, Augusta, GA, was $100 \%$. The atmospheric stability ranged from mildly unstable to neutral during the release perlod. The release trajectory passed Windsor, SC, and could be tracked, with substantially decreased concentration, to the southwest of Columbia, SC.

Measurements were taken of vegetation, surface water, and milk following the release. The highest concentrations were, respectlvely, 7600,140 , and $4.3 \mathrm{pCl} / \mathrm{mL}$. Milk tritium concentrations were within the concentrations normally measured by the SRS Environmental Survey. The air tritiated water vapor content at Windsor was measured at $576 \mathrm{pCl} / \mathrm{m}^{3}$.

March 27, 1985. The release, from the separations area stack, began at 1353 hours EST and averaged about $90 \mathrm{Ci} / \mathrm{min}$ until 1830 hours when the released ceased. Stack sampling indicated that of the $19,422 \mathrm{Cl}$ in the release, $99.9 \%$ was tritlated water vapor.

Meteorological observations at Bush Field, Augusta, $G A$, showed that the cloud cover was $70 \%$ and the wind speed from 16 to $23 \mathrm{~km} / \mathrm{hr}$. The atmospheric stability varied from sllghtly unstable to neutral during the period when the release was passing though South Carolina. The trajectory of the release initially carried the tritium in a northeasterly direction, passing southeast of Columbia, SC.
The release crossed into North Carollnabefore moving over the ocean.

The highest vegetation and surface water concentrations measured within the SRS boundary were 61,800 and $384 \mathrm{pCl} / \mathrm{mL}$, respectively. These values had decreased to 971 and $1.4 \mathrm{pCl} / \mathrm{mL}$ by the time the tritlum reached the SRS boundary. Milk samples collected after the release showed levels that were within the range normally measured by SRS surveys. Alr sampling was done by the TRAC mobile laboratory and sampling teams with mobile tritium forms samplers. The highest concentration of tritium measured in the air was $21,689 \mathrm{pCl} / \mathrm{m}^{3}$. The tritium form of this sample was greater than $99 \%$ tritlated water vapor.

July 31, 1987. The release occurred from the separations area stack between 0817 and n855 hours EST. The estimated total amount released, based on the tritiurn forms monitor, was $172,000 \mathrm{Cl}$. The oxide fraction, based on the stack air monitor, was $2.7 \%$. The remaining $97.8 \%$ was in the hydrogen form.

The weather on July 31 was characterized by very weak wind $(8 \mathrm{~km} / \mathrm{hr})$ blowing toward the northeast and very unstable atmospheric temperature stratification. The height of the atmospheric mixing zone was $200 \mathrm{~m}$ at 0830 hours and $2200 \mathrm{~m}$ by midafternoon. Afternoon showers and the associated wind further dispersed the tritlum as it moved beyond Blackville, SC. Traces of the tritlum were found from Swansea to Orangeburg, SC.

SRS Environmental Monitoring teams collected vegetation, water, and milk samples or and off the site, while SCDHEC collected vegetation samples offsite. The highest concentrations were 5760 and $47 \mathrm{pCl} / \mathrm{mL}$ for 
vegetation and surface water, respectively. The concentration in milk was within the range normally found by SRS Environmental Surveys. Extensive measurements were made of the air concentration with tritium forms samplers. The highest concentration was about 12.4 million $\mathrm{pCi} / \mathrm{m}^{3}$. Samples collected near the release point showed a fairly uniform concentration of tritiated water vapor, averaging around 3\%. Farther from the SRS boundary, the fraction of tritiated water vapor ranged from $0.3 \%$ to $84 \%$ (in a sample with a total tritium concentration of $\left.3300 \mathrm{pCi} / \mathrm{m}^{3}\right)$. The separation of the forms of tritium is thought to be the result of differences in uptake at the surface or from washout of tritium in the vicinity of the rain storms.

March 1, 1988. Approximately $20,000 \mathrm{Ci}$ of tritium were released to the atmosphere from the separations area stack. The tritium forms were $14 \%$ tritiated water vapor and $86 \%$ tritiated hydrogen.

The TRAC mobile laboratory responded to the release, and seven air samples were collected at locations approximately $160 \mathrm{~km}$ southwest of SRS in the vicinity of McRae, GA. Additional air samples were collected along the intersection of US Highway 221 and Interstate Highway 20, west of the TRAC laboratory sampling locations. The tritium concentration in air ranged from $<3.6$ to 85.7 $\mathrm{pCi} / \mathrm{m}^{3}$ of tritiated hydrogen and $<4.3$ to 79.6 $\mathrm{pCi} / \mathrm{m}^{3}$ of tritiated water.

Samples of surface water and vegetation were taken downwind of the release point within the SRS boundary. The highest concentrations were $43 \mathrm{pCi} / \mathrm{mL}$ in vegetation water and $8 \mathrm{pCi} / \mathrm{mL}$ in surface water.

June 7, 1988. Approximately $3650 \mathrm{Ci}$ of tritium were released to the atmosphere from a separations area tritium facility. The release was $96 \%$ tritiated hydrogen gas and $4 \%$ tritiated water vapor.

Environmental sampling was conducted downwind of the release point within the SRS boundan. Eight vegetation samples were collected. The highest concentration in the vegetation moisture was $23 \mathrm{pCi} / \mathrm{mL}$.

October 6, 1988. Approximately $7000 \mathrm{Ci}$ of tritium were released to the atmosphere from a separations area tritium facility. Approximately $11 \%$ of the tritium was in the form of tritiated water vapor. The remaining $90 \%$ was in the form of tritiated hydrogen gas.

Environmental samples were collected within the SRS boundary downwind from the release point. The highest concentrations moasured were $68 \mathrm{pCi} / \mathrm{mL}$ in vegetation and $19 \mathrm{pCi} / \mathrm{mL}$ in standing water.

December 7, 1988. Approximately $3500 \mathrm{Ci}$ oi tritium were released to the atmosphere from a separations area facility. The release was $99.5 \%$ tritiated water vapor, with the remaining $0.5 \%$ tritiated hydrogen gas.

Environmental sampling was conducted downwirid of the release point near the northeast boundary of SRS. The maximum vegetation moisture concentration was 77 $\mathrm{pCi} / \mathrm{mL}$. One surface water sample containing $17 \mathrm{pCi} / \mathrm{rnL}$ of tritium was collected.

Table 2.2 summarizes the conditions immediately after each of the atmospheric tritium releases described above. The releases have taken place under a wicie range of meteorological conditions, during different seasons of the year and beginning at different times of the day. Table 2.3 summarizes the tritium concentration in vegetation, surface 
Table 2.2. Tritium Release Characteristics.

\begin{tabular}{lllllll} 
Date & Iime & $\begin{array}{l}\text { Release } \\
\text { Curles }\end{array}$ & $\frac{1 \text { HTO }}{40}$ & $\begin{array}{l}\text { HTO } \\
\text { Curies }\end{array}$ & $\begin{array}{l}\text { Wind } \\
\text { Speed, m/s }\end{array}$ & $\begin{array}{l}\text { Atmospheric } \\
\text { Stabillty Class }\end{array}$ \\
\hline $5 / 2 / 74$ & 755 & 479000 & 1.0 & 4790 & 3 & Neutral \\
$12 / 31 / 75$ & 2000 & 182000 & 0.6 & 1092 & 10 & Neutral \\
$3 / 27 / 81$ & 845 & 32934 & 100.0 & 32934 & 7 & Unstable \\
$7 / 16 / 83$ & 2013 & 56000 & 1.0 & 560 & 6 & Neutral \\
$3 / 23 / 84$ & 440 & 7500 & 70.0 & 5250 & 5 & Stable \\
$9 / 7 / 84$ & 1900 & 43800 & 100.0 & 43800 & 5 & Stable \\
$1 / 31 / 85$ & 1400 & 9300 & 50.0 & 4650 & 5 & Neutral \\
$3 / 27 / 85$ & 1353 & 19422 & 99.9 & 19403 & 7 & Neutral \\
$7 / 31 / 87$ & 855 & 172000 & 2.7 & 4644 & 2 & Unstable \\
$3 / 1 / 88$ & 616 & 20000 & 15 & 3000 & 4 & Stable \\
$6 / 7 / 88$ & & 3650 & 4 & 146 & 4 & Neutral \\
$10 / 6 / 88$ & 730 & 7086 & 10 & 700 & 7 & Neutral \\
$12 / 7 / 88$ & 2248 & 3082 & 99.5 & 3500 & 5 & Neutral
\end{tabular}

water, and milk samples collected after the nine releases where extensive environmental measurements were made. There is a great deal of variation in the concentration of tritium in environmental samples relative to the amount of tritium released.

In a previous section, it was shown that the annual average tritium concentration in vegetation due to SRS releases is related to the air concentration of tritiated water vapor. Annual vegetation tritium concentrations tend to average the effects of specific meteorological conditions from any one release, making it easier to see the patterns due to other factors. However, it is possible to take into account meteorologic effects by using atmospheric models. For an atmospheric release of short duration, the concentration of tritiated water in the leaves of

Table 2.3. Maximum Environmental Concentrations Following Tritium Releases, $\mathrm{pCi} / \mathrm{ml}$.

\begin{tabular}{|c|c|c|c|c|c|c|}
\hline \multirow[b]{2}{*}{ Daie } & \multicolumn{4}{|c|}{ Vegetation } & \multirow{2}{*}{$\begin{array}{l}\text { Surface } \\
\text { Water }\end{array}$} & \multirow[b]{2}{*}{ Milk } \\
\hline & On Site & Perimeter & $\sim 40 \mathrm{~km}$ & $\sim 80 \mathrm{~km}$ & & \\
\hline $5 / 2 / 74$ & 25 & 4630 & 310 & 41 & 138 & 375 \\
\hline $12 / 31 / 75$ & 687 & 92 & 8 & & 3 & 9 \\
\hline $3 / 27 / 81$ & 4860 & 270 & & & 9 & 11 \\
\hline $7 / 16 / 83$ & 150 & 110 & 80 & 27 & 23 & 4 \\
\hline $3 / 23 / 84$ & 89 & 500 & 1380 & 190 & 120 & 69 \\
\hline $9 / 2 / 84$ & 500 & 2500 & 9900 & 240 & ND & 47 \\
\hline $1 / 31 / 85$ & 7600 & 450 & 380 & 180 & 140 & 2 \\
\hline $3 / 27 / 85$ & 61800 & 970 & 590 & 143 & 384 & 6 \\
\hline $7 / 31 / 87$ & 5760 & 4690 & 34 & 8 & 47 & 4 \\
\hline
\end{tabular}




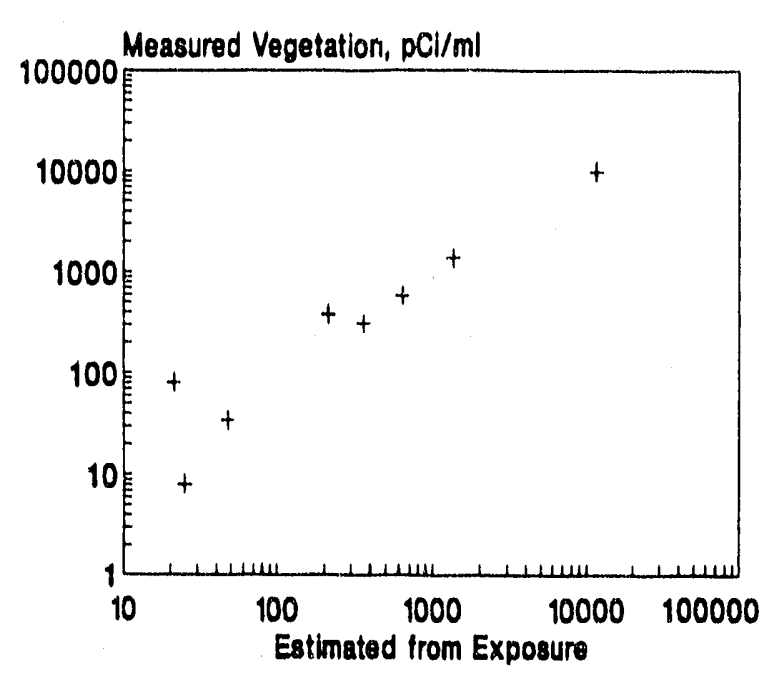

Figure 2.22. The Maximum Tritiated Water Content of Vegetation Leaves Collected at Approximately $40 \mathrm{~km}$ from the Source of the Release Compared to Estimates Calculated from Exposure to Tritiated Water Vapor for Each Release

vegetation should be related to the exposure of the leaf to the tritiated water vapor in the air. Exposure, the average concentration in the air multiplied by the time of contact with that air, can be calculated using the model described by Slade (1968). Figure 2.22 shows the results of calculations of the maximum centerline exposure compared to the maximum concentration measured in the vegetation at approximately $40 \mathrm{~km}$ from the release source. The meteorological conditions shown in Table 2.2 were used in the calculations. The concentration in the vegetation immediately after the passage of the release is a function of the exposure to tritiated water vapor.

The decrease in tritium concentration in the environment was followed after some of the larger inadvertent releases. The pattern of decrease in the tritiated water content of vegetation was found to differ between releases where the tritium was largely in the hydrogen form and releases where the tritium was largely in the water vapor form. Table 2.4 shows a comparison of two releases, one of which was largely water vapor and the other that was largely hydrogen gas.

When the release was in the water vapor form, the highest concentration of tritium found after the release was in the vegetation leaves. The concentration in the soil was comparatively small. The tritiated water content of the leaves decreased very rapidly after exposure. The concentration had decreased to half the highest value within a few hours of exposure.

When the release was in the hydrogen form, the highest concentration of tritium was found in the soil water. The tritiated water content of the vegetation leaves decreased more slowly than in the exposure to tritiated water. The decrease to half the maximum value took nearly 5 days (Figure 2.23). The tritiated water found in the leaves is largely from oxidation of tritiated hydrogen to tritiated water by microorganisms in the soil. When

\section{Table 2.4. Comparison of Characteristics of HTO and HT Releases.}

\begin{tabular}{|c|c|c|c|c|c|c|}
\hline \multirow[b]{2}{*}{$\frac{\text { Date }}{5 / 2 / 74}$} & \multirow[b]{2}{*}{ Eorm } & \multirow[b]{2}{*}{$\begin{array}{l}\text { Release } \\
\text { Curles }\end{array}$} & \multicolumn{2}{|c|}{ Maximum HTO Concentration } & \multirow[b]{2}{*}{$\begin{array}{l}\text { Release/ } \\
\text { Maximum }\end{array}$} & \multirow{2}{*}{$\begin{array}{l}\text { Vegetation } \\
\text { Half-life } \\
\text { In Days }\end{array}$} \\
\hline & & & $\begin{array}{l}\text { Vegetation } \\
\text { pelimi } \\
4600\end{array}$ & $\begin{array}{l}\text { Soll } \\
\frac{\mathrm{DCl} / \mathrm{ml}}{7240}\end{array}$ & & \\
\hline $3 / 27 / 81$ & HTO & 32934 & 4900 & 40 & 0.15 & $\ll 1$ \\
\hline
\end{tabular}




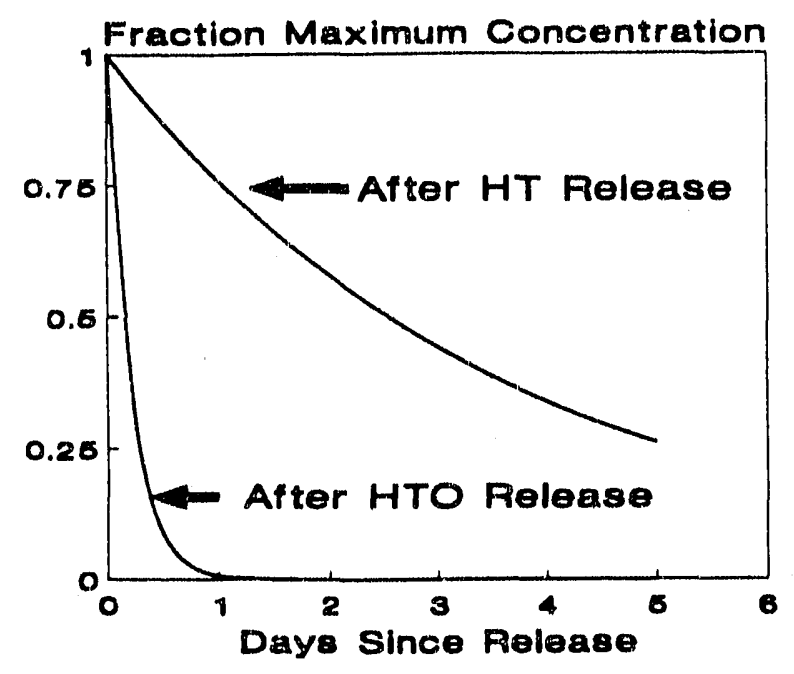

Figure 2.23. The Characteristic Release Curves for Tritiated Water in Vegetation Following Exposure to Atmospheric Tritlated Water Vapor and Tritiated Hydrogen

compared to a tritiated water vapor exposure, the longer exposure of vegetation to tritiated water after an exposure of the system to tritiated hydrogen is more than compensated for by the lower maximum concentration of tritium in any component of the environment relative to the total amount of tritium released.

\section{SRS SURFACE WATER TRITIUM RELEASES AND TRANSPORT}

Tritium accounts for more than $98 \%$ of the radioactivity in the Savannah River. From 1954 to 1988 , about 1.5 million Ci of tritium of SRS origin were released to the Savannah River (Table 2.5). Of this original release, about $59 \%$ has decayed to helium and most of the other $41 \%$ is in the North Atlantic Ocean circulation system.
Table 2.5. Llquid Tritlum Reliases (19541988).

Tritium Roloases to Straams

\begin{tabular}{|c|c|c|c|}
\hline Alver & $\begin{array}{l}\text { Direot } \\
\text { Roleases } \\
\text { to Stream: }\end{array}$ & $\begin{array}{l}\text { Seopege } \\
\text { 10 } \\
\text { Streams }\end{array}$ & $\begin{array}{l}\text { Orlolinal } \\
\text { Totial } \\
\text { Roloace }\end{array}$ \\
\hline
\end{tabular}

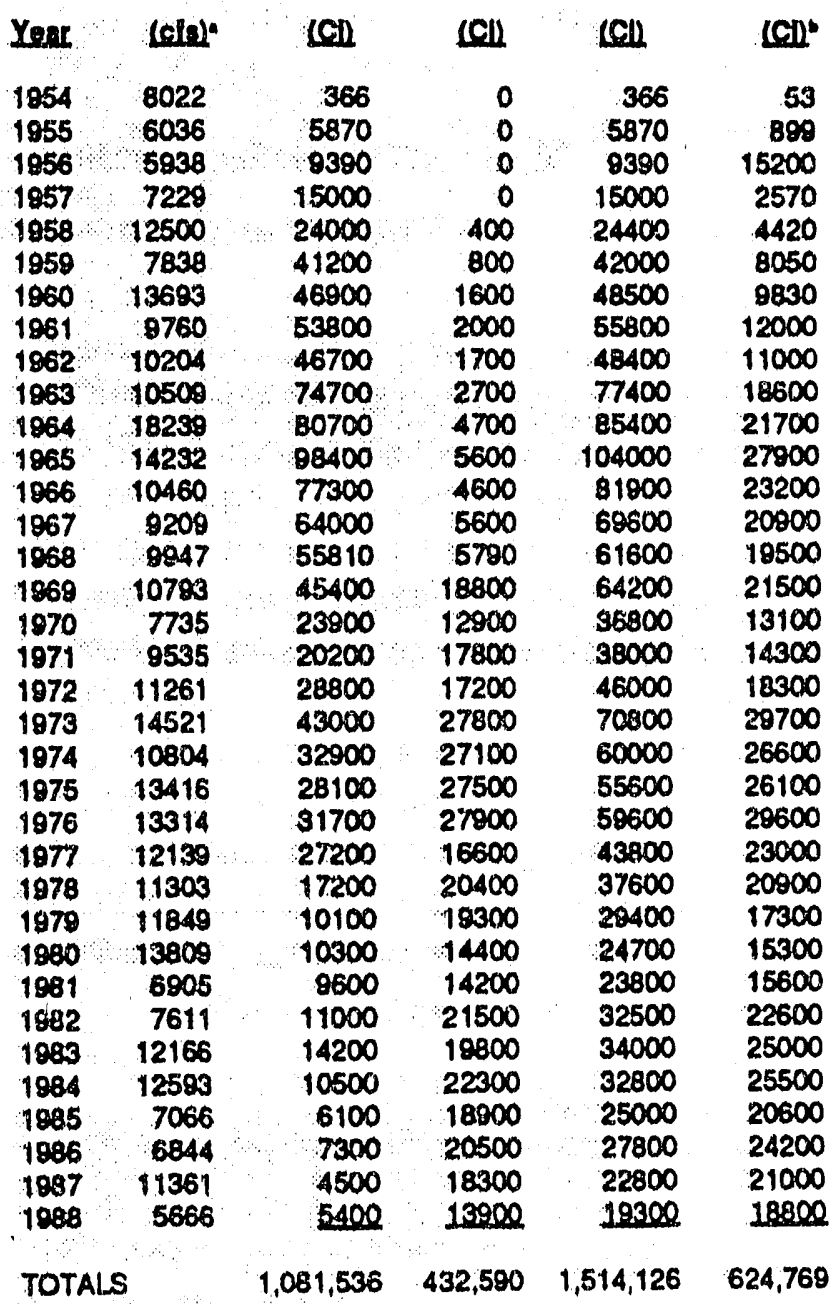

Notes:

- Flow rate data for downstroam dose calculations based on USGS measuremants at Augusta, GA (1953-1972) and the SRS boat dock (1973-1988) + 10\%.

- Annual relaases have been decay-corrected to 01-01-89. 


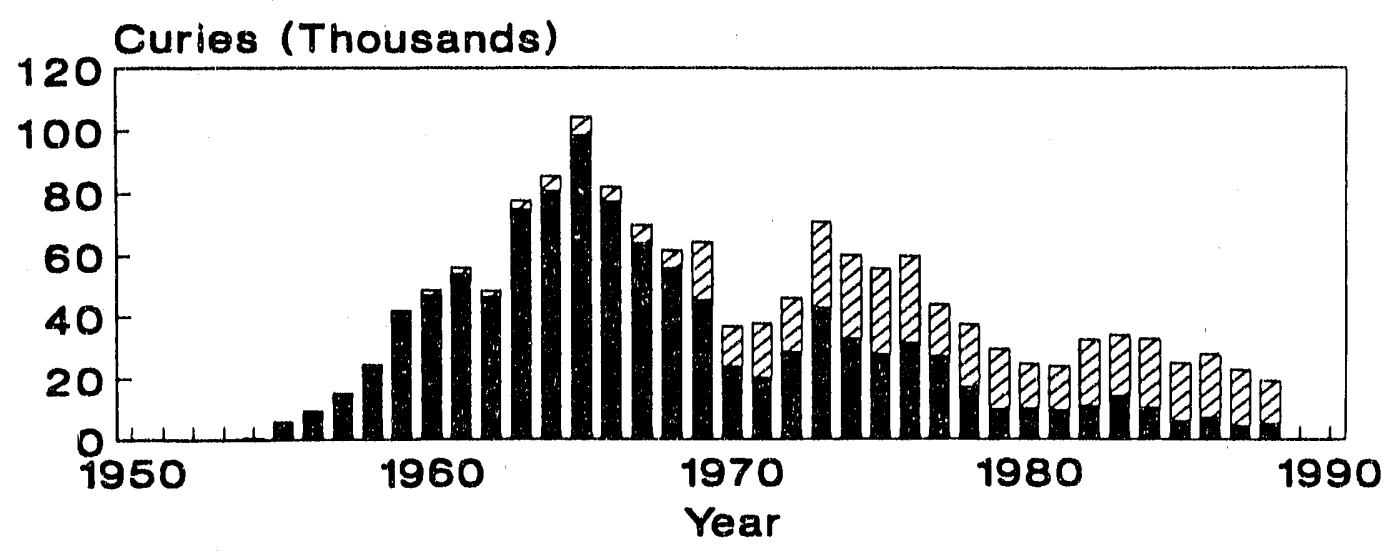

\section{SRS Direct Release PIAS SRS Seepage Release}

Figure 2.24. Total Tritium in Streams From Direct Release and Seepage Through Groundwater

The sources of tritium in SRS surface waters include direct releases from SRS facilities and migration of tritium primarily from the $F$ - and H-Area seepage basins, the Burial Ground, and the K-Area containment basin. Migration occurs when tritium that has been released to these earthen basins in previous years reaches onsite streams via shallow groundwater that outcrops into the streams. Since the mid1970 s, migration has accounted for most of SRS tritium releases to surface waters (Figures 2.24 and 2.25). A detailed discussion on the migration of tritium from various facilities is presented in the following sections.

\section{Tritium Releases}

An accounting of the amount of tritium released from SRS facilities began with SRS startup in 1953. Measurements of the amount in transport in SRS streams and the Savannah River began in the latter half of 1959. Relatively good agreement in the inventory of tritium measured at three locations (the point of release, plant streams before entry into the river, and the river below SRS) has been observed each year since the totals have been compiled, beginning in 1960 (see Figure 2.26 for sampling locations).
Before 1959, low-level measurement techniques needed for routine measurements of tritium concentrations in streams and the river were not available. The lower limit of detection prior to 1959 was $1000 \mathrm{pCi} / \mathrm{mL}$. Liquid scintillation counters, developed in the 1950s, made low-level measurements practical in streams and the Savannah River.

SRS began routine use of liquid scintillation counting in 1959. River and stream measurements began in the last half of that year. During some of the early years (19601964), significant differences occurred between releases and the amount of tritium measured in streams and the river (Figure 2.27). These differences led to the addition of effluent monitoring points where small amounts of tritium are released (miscellaneous reactor releases) and the measurement of moderator leakage from the reactor heat exchangers to the cooling water.

Transport data indicate that essentially all tritium released from SRS to flowing surface waters remains in solution, except for minor evaporative losses, and is transported to the Savannah River (Figure 2.27). As shown in Figure 2.27, tritium releases to the Savannah 


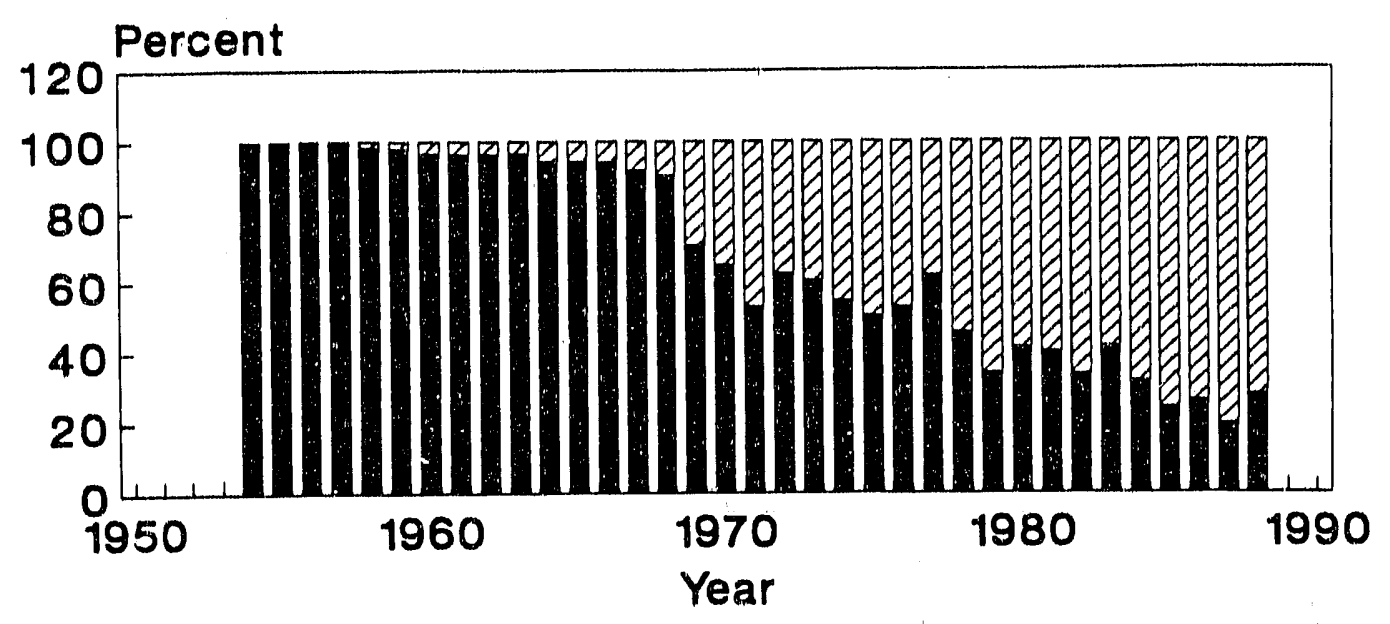

SRS Direct Release VIIA SRS Seepage Release

Figure 2.25. Percentage of Tritlum in Streams from Direct Release and Seepage Through Groundwater

River have decreased significantly since 1964.

Process control improvements have led to the decrease of tritium releases. These improvements include: (1) change from continuous purges of reactor area disassembly basins to periodic purges in the late 1960s, allowing longer holding time for decay, some evaporation, and a larger inventory of tritium in the basins; (2) development of equipment and techniques to flush and contain tritiumbearing moderator present on fuel and target housings during discharge from the reactor; and (3) diversion of periodic disassembly basin purges from streams to seepage basins in $P$ and $C$ areas in 1978, allowing some radioactive decay of tritium before migration to streams via groundwater.

\section{Transport and Dilution}

The transport and concentration of tritium as HTO (water that has a protium atom replaced with a tritium atom) in streams and rivers is determined by the processes of volumetric dilution, advection, and turbulent diffusion. Volumetric dilution of tritiated water occurs when there is an increase in water flow volume. A decrease in tritium concentration occurs when a stream containing tritium mixes with a river having a lower tritium concentration.

Advection is the movement of tritiated water with the bulk flow of the water. Tritium as HTO is carried along and has the same general speed and direction as the water flow.

Turbulent diffusion or dispersion in surface waters is the process in which dilution of HTO takes place through the action of eddy water currents. This process is important in the initial dilution of short-period releases and is less important as the width of a peak increases. The process is not so important in the dilution of releases that are longer than a day. The concept is similar to atmospheric diffusion except that the process in streams has easily defined boundaries. 


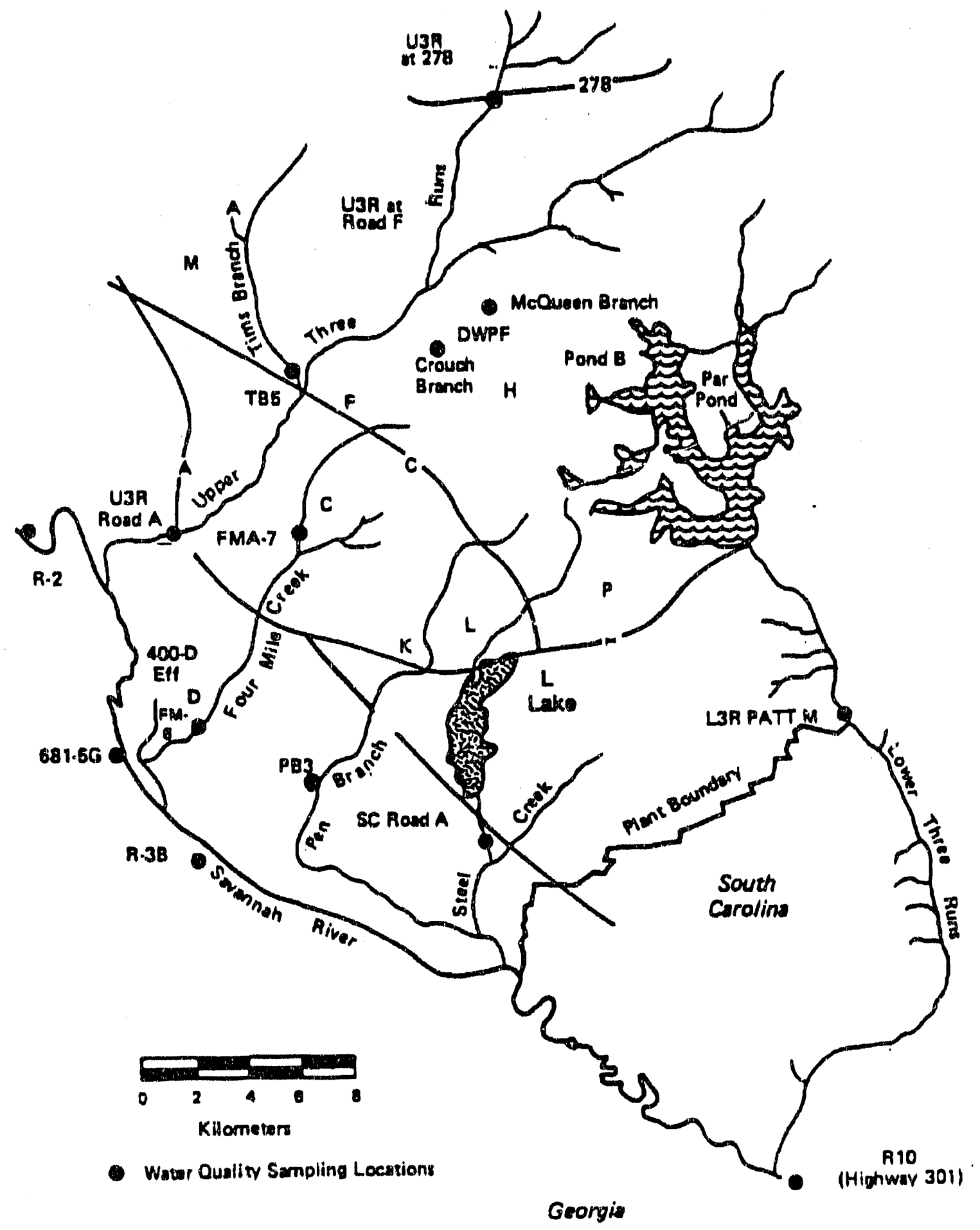

Figure 2.26. Stream Locations Monitored for Tritium Concentration 


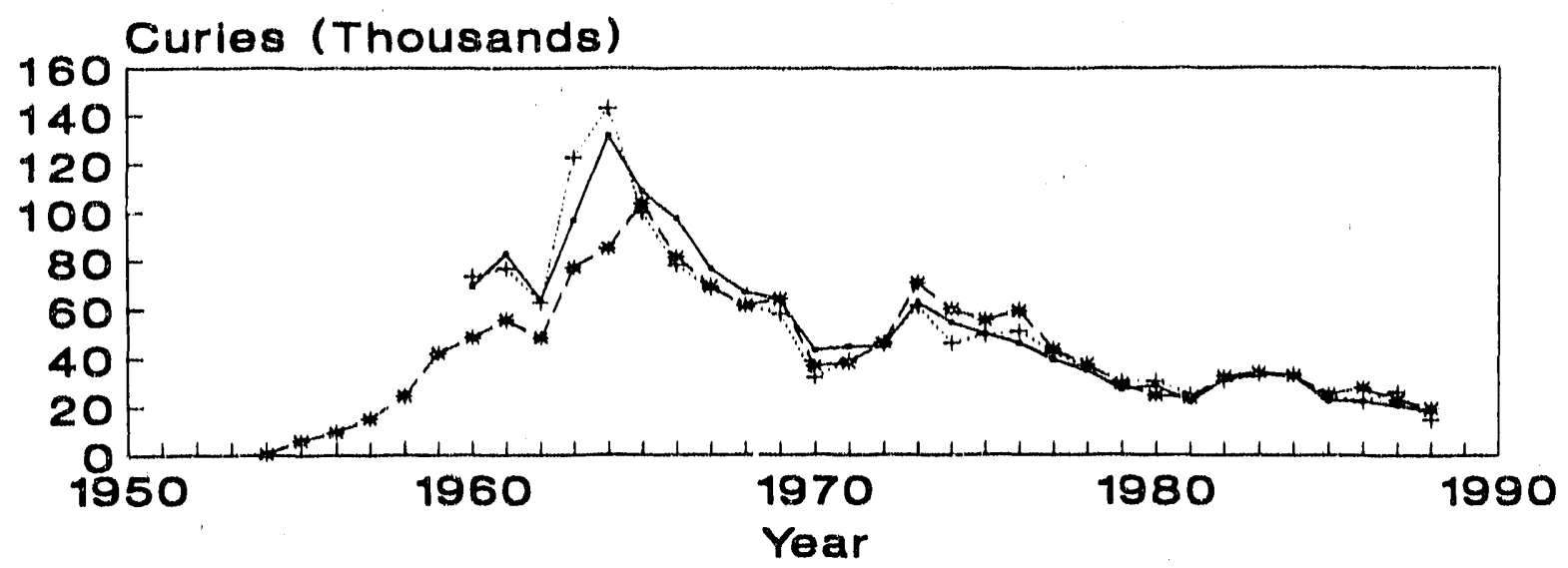

_ Total in Streams

S R at Highway 301

- Total Released

Figure 2.27. A Comparison of Total Tritlum Measured in SRS Creeks and the Tritlum Measured in the Savannah River at Highway 301 Downstream from SRS

\section{SRS Surface Water System}

Almostall of the SRS is drained by tributaries of the Savannah River: Upper Three Runs Creek, Beaver Dam Creek, Four Mile Creek, Pen Branch, Steel Creek, and Lower Three Runs Creek (Figure 2.26). Only one small unnamed stream in the northeastern sector of the site drains to the Salkehatchie River to the east. (No SRS facilities discharge to this stream.)

Three large impoundments are located on two of the SRS streams that drain into the Savannah River. The largest of these, Par Pond, has an area of 2640 acres and is located on Lower Three Runs Creek. Pond B, a smaller impoundment consisting of 180 acres, is immediately upstream of Par Pond. L Lake has an area of 1000 acres and is part of the Steel Creek system.

The source of most of the surface water on the site is elther rainfall or water pumped from the Savannah River to cool the nuclear reactors. The cooling water is discharged to streams or lakes that flow back to the river. Additional small amounts of water are discharged from other plant processes to streams. Minor additions of water come from natural springs and seepage basin outcrops.'

Very little water enters the groundwater through the stream beds. However, water in the large impoundments may enter local porous ground structures and travel short distances. For instance, some of the water in the springs below Par Pond dam has been Identified as water from Par Pond (Langley and Marter 1973).

\section{Flows}

Tritium concentrations in SRS streams and the Savannah River are determined by the tritium release rate and the stream or river flow. An increase in the amount of water flowing in a stream decreases the tritium 
concentration for a given release. Increases in stream flows occur at SRS due to process and coolling water dlscharges. SRS dlscharges can increase natural stream flows by factors of 2 to 15 .

Water discharges from a facillty are governed by process needs, and the flow variation throughout a year can be greater than in a natural system. Reactor operations have the greatest impact on water flows. For instance, when C Reactor was operating, Four Mile Creek had an average flow of 377 $\mathrm{tt}^{3 / \mathrm{s}}$ in 1984, and after C Reactor was placed in standby in 1985, the annual flow dropped to $31 \mathrm{ft} / \mathrm{s}$ in 1988. An operating reactor can be up and down several times a year. If tritium is being released at a constant rate to a stream, the tritium concentration can vary depending on the stream flow rate.

\section{SRS Streams}

Tritlum is released to SRS streams by direct releases from facillties and by migration from seepage basins (Figure 2.28). A decline in the percent contribution from direct discharges began in the mid 1970 s and has continued. In 1988 , about $72 \%$ of the tritium in the streams came from migration and $28 \%$ by direct discharge from facillities. These percentages are calculated from the tritlum inventory estimates that are made yearly (see Table 2.6) for all site streams and the Savannah River (Davis et al. 1981). At present only Four Mille Creek and Pen Branch receive a major portion of their tritium content from the migration pathway $(10,980 \mathrm{Cl}$ and $2780 \mathrm{Cl}$, respectively). Steol Creek recelves less than $200 \mathrm{Cl} / \mathrm{yr}$.

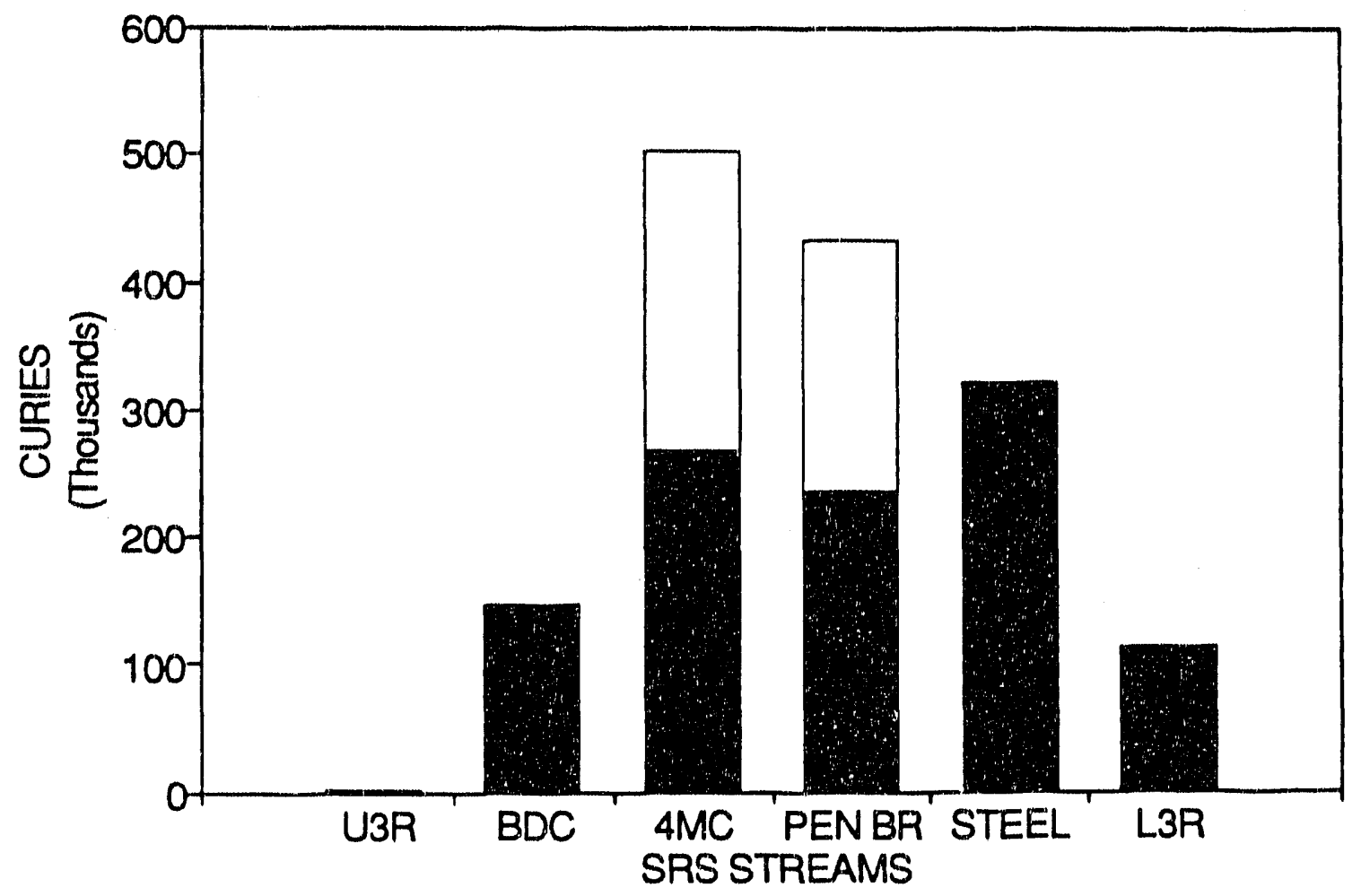

DIRECT RELEASE MIGRATION RELEASE

Figure 2.28. Total Releases to SRS Streams by Elther Direct Release to the Stream or Seepage from the Groundwater 
Table 2.6. Trttlum Inventory In SRS Streams and the Savannah River.

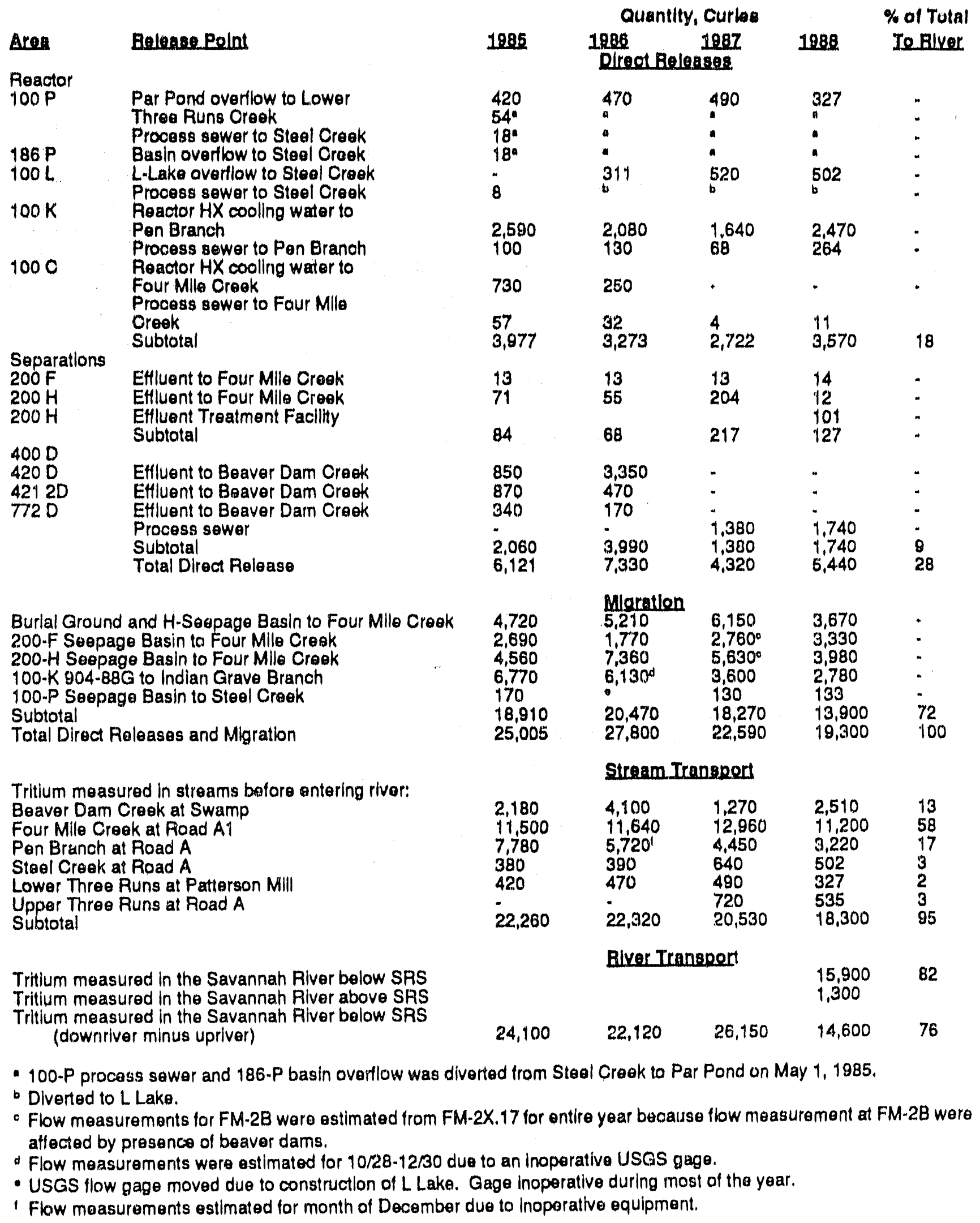


Since the early 1960s, tritium concentration measurements have been made at a network of monitoring stations on five of the SRS streams and the Savannah Fiver. A summary of these measurements is found in Table 2.7. Beaver Dam Creok tritlum conoentration measurements were not started untll the early 1970s. The tritlum measurements are reported In the Health Protection Annual Reports (se日 Appendix 2, Bibllography) and include the yearly average, the weekly or biweekly maximum, and minimum tritium concentrations for each sampling location. Reporting of the minimum tritlum concentration was not started untll the early 1970s. Detalls of the monitoring and measurement techniques are provided in Appendix 1 of this publication. Tritium concentrations from the farthest downstrearn monitoring location will

Table 2.7. Tritlum Concentrations in SRS Streams and the Savannah River (19541988).

\begin{tabular}{|c|c|c|c|}
\hline $\begin{array}{l}\text { Creek/RIver } \\
\text { System }\end{array}$ & $\begin{array}{l}\text { Average } \\
\text { pel/mL }\end{array}$ & $\begin{array}{l}\text { Standard } \\
\text { Deviation } \\
\text { (pel/mlis) }\end{array}$ & $\begin{array}{l}\text { Maximum } \\
\text { (DCel/mL) }\end{array}$ \\
\hline $\begin{array}{l}\text { Upper Three } \\
\text { Runs }\end{array}$ & 3.7 & 1.1 & 3.6 \\
\hline Beaver Dam & 47 & 20 & 1400 \\
\hline Four Mile & 118 & 191 & 3500 \\
\hline Pen Branch & 90 & 116 & 14228 \\
\hline Steel & 124 & 141 & 3500 \\
\hline $\begin{array}{l}\text { Lower Three } \\
\text { Runs }\end{array}$ & 14 & 18 & 208 \\
\hline $\begin{array}{l}\text { Savannah Rivel } \\
\text { Above SRS }\end{array}$ & 1.2 & 1.5 & 29 \\
\hline
\end{tabular}

be used for this discussion so that all SRS facillty releases to that stream are included.

\section{Lower Three Runs Creek}

$P$ and $R$ Reactors discharge to the Lower Three Runs Creek system. Lower Three Runs Creek has the second largest drainage area (about $153 \mathrm{~km}^{2}$ ) of the SRS streams. Par Pond was construoted and filled to recelve cooling waters from $P$ and $R$ reactors in 1957 . 1958. It is located near the headwaters of Lower Three Runs Creek. Par Pond covers 2640 acres to an average depth of $6 \mathrm{~m}$. From the dam, Lower Three Runs Creek flows about $39 \mathrm{~km}$ before it enters the Savannah River. The narrow strip of land between the dam and the river, which includes the floodplain, is part of the SRS. Several other small ponds were constructed in the headwaters above Par Pond to improve cooling of the reactor effluent. The largest of these is Pond B (about 180 acres).

Before construction of Par Pond, effluent cooling water from R Reactor (about $200 \mathrm{ft}^{3} / \mathrm{s}$ ) was discharged via Joyce Branch to Lower Three Runs Creek. Since Par Pond was filled in 1958, the overflow to Lower Three Runs Creek has varied, depending on the utillization of the pond cooling water system by $P$ and $R$ Reactors. In 1964, RReactor was shut down, and P-Reactor cooling water was diverted from Steel Creek to Par Pond. Flows from Par Pond to Lower Three Runs Creek are considerably less than current reactor operation requirements of $400 \mathrm{tt}^{3} / \mathrm{s}$, due to recirculation of cooling water. In 1988, the average flow from Par Pond to Lower Three Runs Creek was about $37 \mathrm{ft}^{3 /} / \mathrm{s}$.

About $113,099 \mathrm{Cl}$ of tritium have been discharged directly to the Lower Three Runs Creek system from $P$ and $R$ Reactors (Flgure 
2.29). No migration sources of tritlum to this system have been identifled. A Reactor released about $78,853 \mathrm{Cl}$ to Lower Three Runs Creok prlor to its shutdown in 1964. $P$ Reactor released about $34,246 \mathrm{Cl}$ of tritlum to Par Pond between 1974 and 1988. Between 1964 and 1974 , no measurements were made of tritium transport from $P$ A.rea to Par Pond. Tritium transport measurements made at the Par Pond darn indloate that less than 18,000 $\mathrm{Cl}$ would have been released from $\mathrm{P}$ Reactor during the years that measurements were not made on $P$ Reactor releases to Par Pond. Most of the tritlum, $14,000 \mathrm{Cl}$, released from Par Pond between 1964 and 1968 was probably due to $R$ Reactor releases to $\mathrm{Par}$ Pond prior to 1965 (Figures 2.29 and 2.30).

Tritlum concentrations are measured on composited water samples collected weekly or biweekly from a paddle wheel sampler located below SC State Road 20 (Patterson's Mill). Tritlum concentrations averaged 13.4 $\mathrm{pCl} / \mathrm{mL}( \pm 18 \mathrm{pCl} / \mathrm{mL})$ between 1959 and 19813. The highest weekly concentration was 2018 $\mathrm{pCl} / \mathrm{mL}$ measured in 1964 (Table 2.7 arid Flgure 2.31). The average tritlum concentratlons have decreased significantly since the mid-1960s due to operation and process improvements. Tritlum concentrations now average about $5 \mathrm{pCl} / \mathrm{mL}$ in Lower Three Runs Creek at Patterson's Mill. The maximum concentration occurred in 1964 and was probably assoclated with shutdown actlvities in R-Reactor Area.

Tritlum concentrations below the Par Pond dam are decreased by natural flow additions between Par Pond dam and the river. For instance, the tritium concentration decreased $44 \%$ (from $8.9 \mathrm{pCl} / \mathrm{mL}$ to $5 \mathrm{pCl} / \mathrm{mL}$ ) between Par Pond dam and Patterson's Mill about

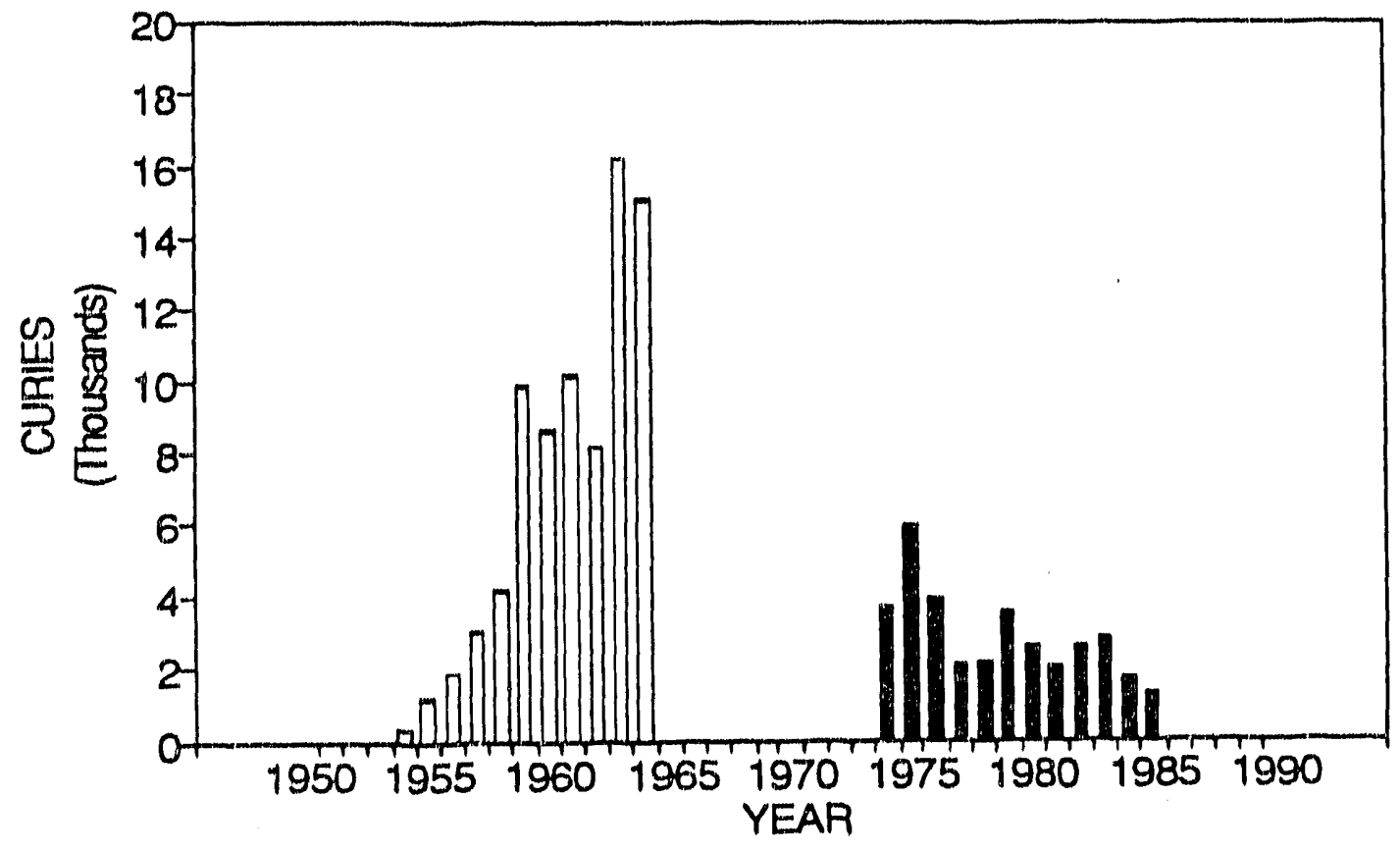

RREACTOR PAEACTOR

Figure 2.29. Tritlum Releases from P. and R-Reactor Areas 


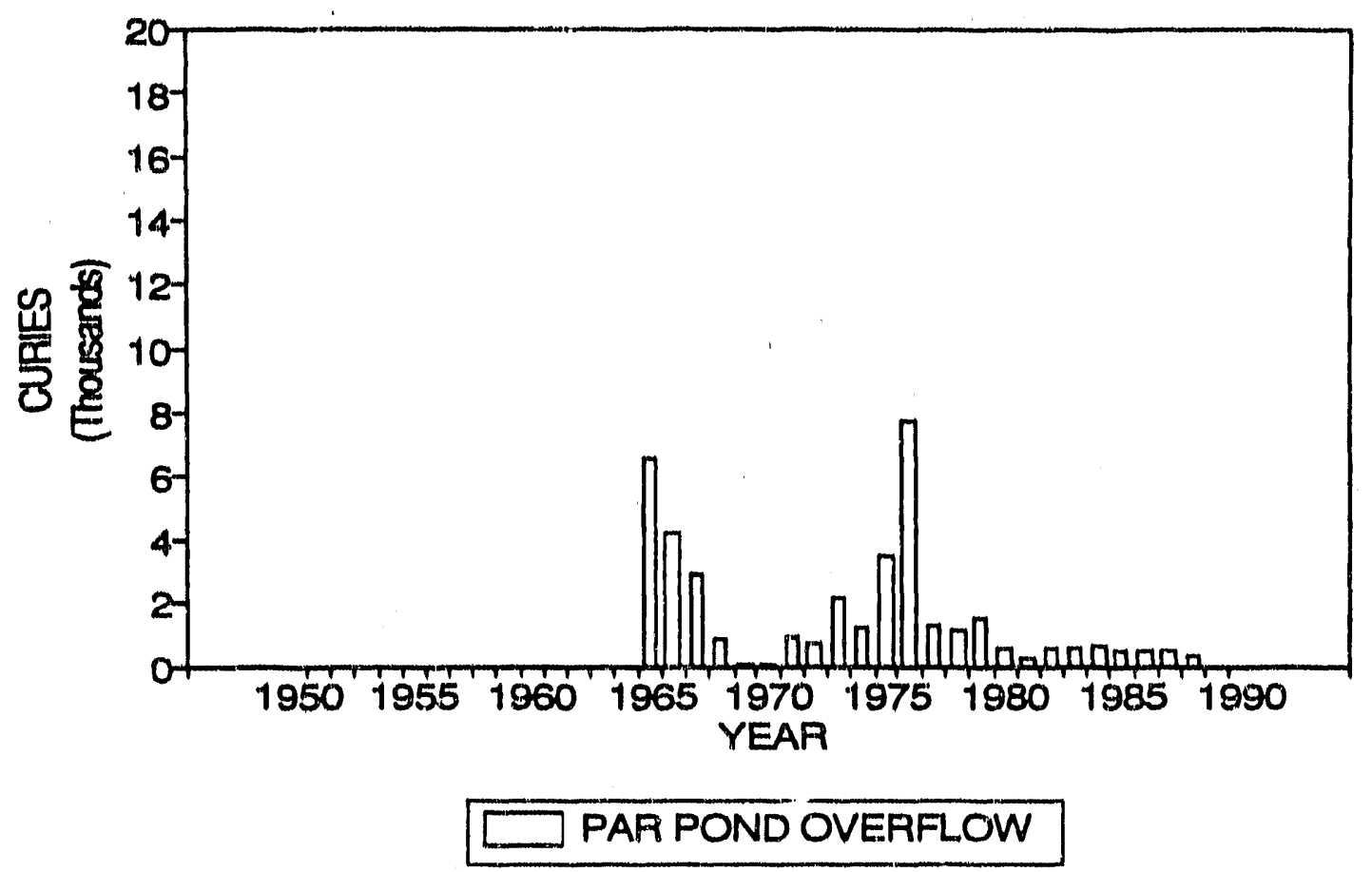

Figure 2.30. Tritium Releases from Par Pond to Lower Three Runs Creek

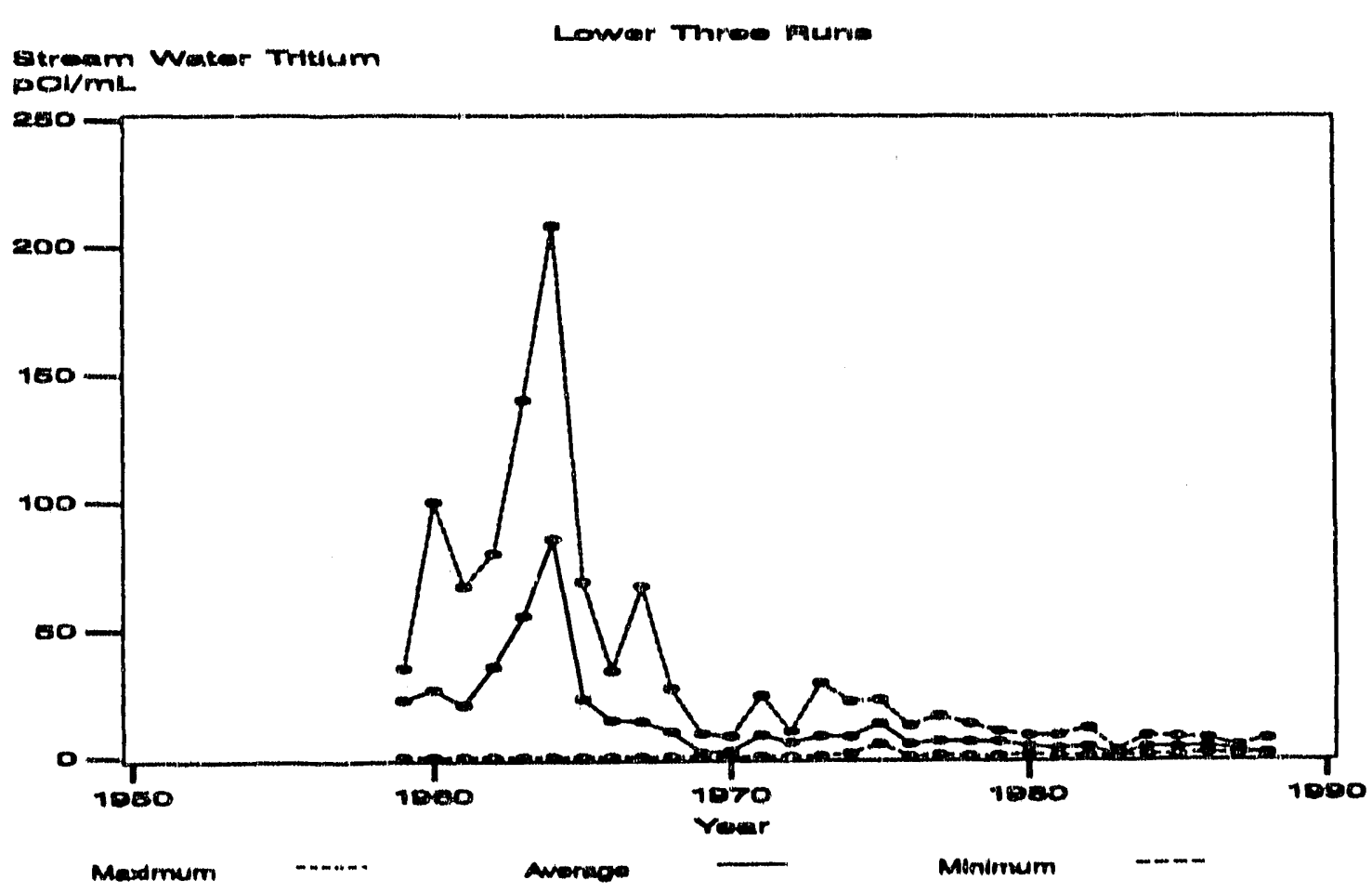

Figure 2.31. Tritlum Concentrations In Lower Three Runs Creek at Patterson's Mill 
$9.7 \mathrm{~km}$ downstream. This decrease is primarily accounted for by the increase in flow between the two locations. Further dilution occurs between Patterson's Mill and the river about $29 \mathrm{~km}$ downstream.

\section{Steel Creek}

$P$ and $L$ Reactors discharge effluents to Steol Creek. Steel Creek headwaters are at the P-Area outfall on Steel Creek. The creek flows southwesterly about $3 \mathrm{~km}$ before it enters the headwaters of L Lake. L Lake was built in 1985 to provide cooling for L-Reactor thermal discharges. The lake is $6.5 \mathrm{~km}$ long and relatively narrow, with an area of 1000 acres. Flow from the outfall of L-Lake dam travels about $5 \mathrm{~km}$ before entering the Savannah River swamp and then another $3 \mathrm{~km}$ before entering the Savannah River. The main tributary of Steel Creek is Meyers Branch.
Pen Branch enters Steel Creek about $0.4 \mathrm{~km}$ from the mouth of Steel Creek on the Savannah River. The Steel Creek watershed has an area of about $91 \mathrm{~km}^{2}$, not including Pen Branch. The volume of water dlscharged from $P$ and $L$ Reactor areas to Steel Creek has varied over the years of operation. L Reactor was shut down in 1968, then restarted in 1985. P. Area coollng water was diverted from Steel Creek to ParPond in 1964. These changes in operation have caused a wide varlation in the flows and the amount of tritium released to Steel Creek. Flows have varled from $800 \mathrm{Ht}^{3 / \mathrm{s}}$ in the early 1960s, to $400 \mathrm{ft} / \mathrm{s}$ in the late 1970 s and early 1980s. Beginning in 1985 with L-Reactor restart, flows were increased to $400 \mathrm{H} / \mathrm{s}$.

About $315,000 \mathrm{Cl}$ of tritium have been released to Steel Creek from P-and L-Reactor areas to Steel Creek. Tritium releases have significantly decreased in Steel Creek, with

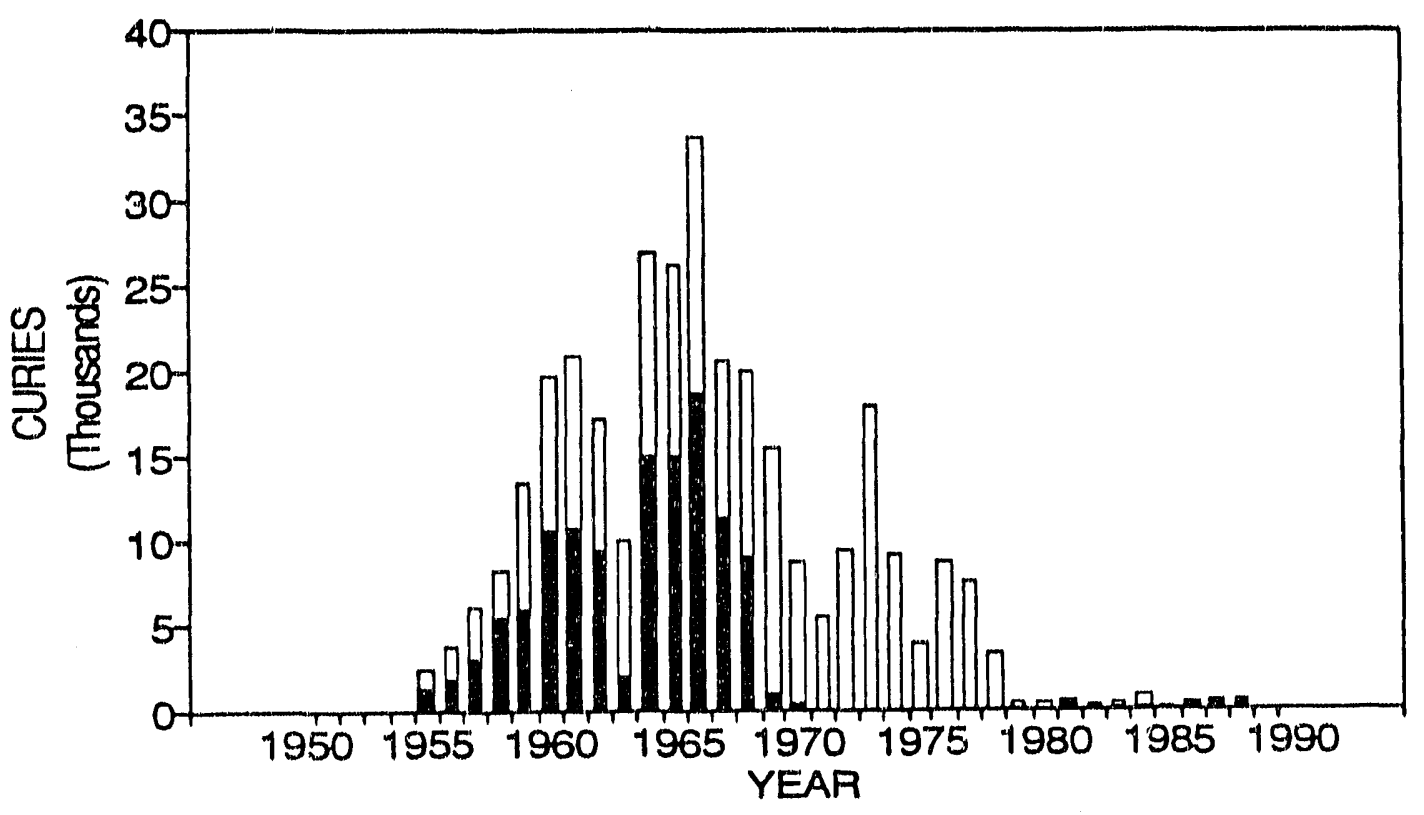

L REACTOR

P REACTOR

Figure 2.32. P. and L-Reactor Area Releases to Steel Creek 
the shutdown of $L$ Reactor in 1968 and the diversion of P-Area process effluents to a seepage basin in 1985 (Figure 2.32). The restart of L Reactor in 1985 has not caused a majorincrease in the amount of tritium released in Steel Creek. Tritium migration from the P. Area se日page basin accounts for about $130 \mathrm{Ci} /$ yr of tritium in transport in Steel Creek.

Tritium concentrations are measured on composited water samples collected weekly or biweekly from a paddle wheel sampler located at Hattieville Bridge about $3.2 \mathrm{~km}$ below SC Highway 125 (SRS Road A). The Steel Creek monitoring location was moved to this location from Hattieville Bridge in 1985. Tritium concentrations averaged $124 \mathrm{pCi} / \mathrm{mL}$ $( \pm 141 \mathrm{pCi} / \mathrm{mL})$ between 1959 and 1988 . The highest weekly concentration was $3500 \mathrm{pCi}$ $\mathrm{mL}$ measured in 1969 (Table 2.7 and Figure 2.33). After L-Reactor shutdown in 1968, the tritium concentrations in Steel Creek increased due to reduced flows. The flow decreased frum $400 \mathrm{ft}^{3 / 5}$ to $30 \mathrm{ft}^{3} / \mathrm{s}$, reducing the water available for dilution. Tritium releases from $P$ Reactor to Steel Creek remained the same until all process effluents were diverted to a seepage basin in 1985.

\section{Pen Branch}

$K$ Area is the only SRS facility that discharges to Pen Branch. Pen Branch lies batween Four Mile Creek and Steel Creek, and its flow path is similar to Four Mile Creek. The creek follows a southwesterly path for 24 $\mathrm{km}$, from its headwaters about $3.2 \mathrm{~km}$ east of $\mathrm{K}$ Area to the Savannah River swamp. After entering the swamp, the creek flows parallel to the Savannah River for about $8 \mathrm{~km}$ before it enters and mixes with the waters of Steel Creek about $0.4 \mathrm{~km}$ from the mouth of Steel Creek on the Savannah River. Indian Grave Branch is the only significant tributary. It carries cooling water from $K$ Reactor to Pen Branch. The Pen Branch watershed is about $55 \mathrm{~km}^{2}$. The natural flow of this creek would be about 5 to $10 \mathrm{ft} / \mathrm{s}$, but this flow is increased to about $400 \mathrm{ft}^{3} / \mathrm{s}$ by flow from K Area.

Of the $433,000 \mathrm{Ci}$ of tritium released to $P$ en Branct from K-Area operations, about 54\% has been released directly and about $46 \%$ has been through migration (Figure 2.34). Migration of tritium from the K-Area seepage basins has been the major source of tritium in Pen Branch since 1969 (du Pont 1986).

Tritium concentrations are measured on composited water samples collected weekly or biweekly from a paddle wheel sampler located below SC Highway 125 (SRS Road A). Tritium concentrations averaged $90 \mathrm{pCi} /$ $\mathrm{mL}( \pm 116 \mathrm{pCi} / \mathrm{mL})$ between 1959 and 1988. The highest weekly concentration was 14,338 $\mathrm{pCi} / \mathrm{mL}$ measured in 1964 (Table 2.7 and Figure 2.35). The average tritium concentrations have decreased significantly since the mid-1960s due to operation and process improvements. Tritium concentrations now average about $48 \mathrm{pCi} / \mathrm{mL}$ in Pen Branch, and further decreases are expected as tritium releases from seepage basin sources continue to decrease.

\section{Four Mile Creek}

Four Mile Creek begins near the center of the SRS and follows a generally southwesterly path for about $24 \mathrm{~km}$ to the river. The total watershed is onsite and drains about $57 \mathrm{~km}^{2}$. The watershed includes several SRS facilities: $\mathrm{F}$ - and $\mathrm{H}$-separations areas, $\mathrm{C}$-Reactor Area, the Burial Ground, and F- and $\mathrm{H}$-seepage basins.

The natural flow of about $5 \mathrm{t}^{3} / \mathrm{s}$ is increased by $\mathrm{F}$ - and $\mathrm{H}$-Area process effluents and 


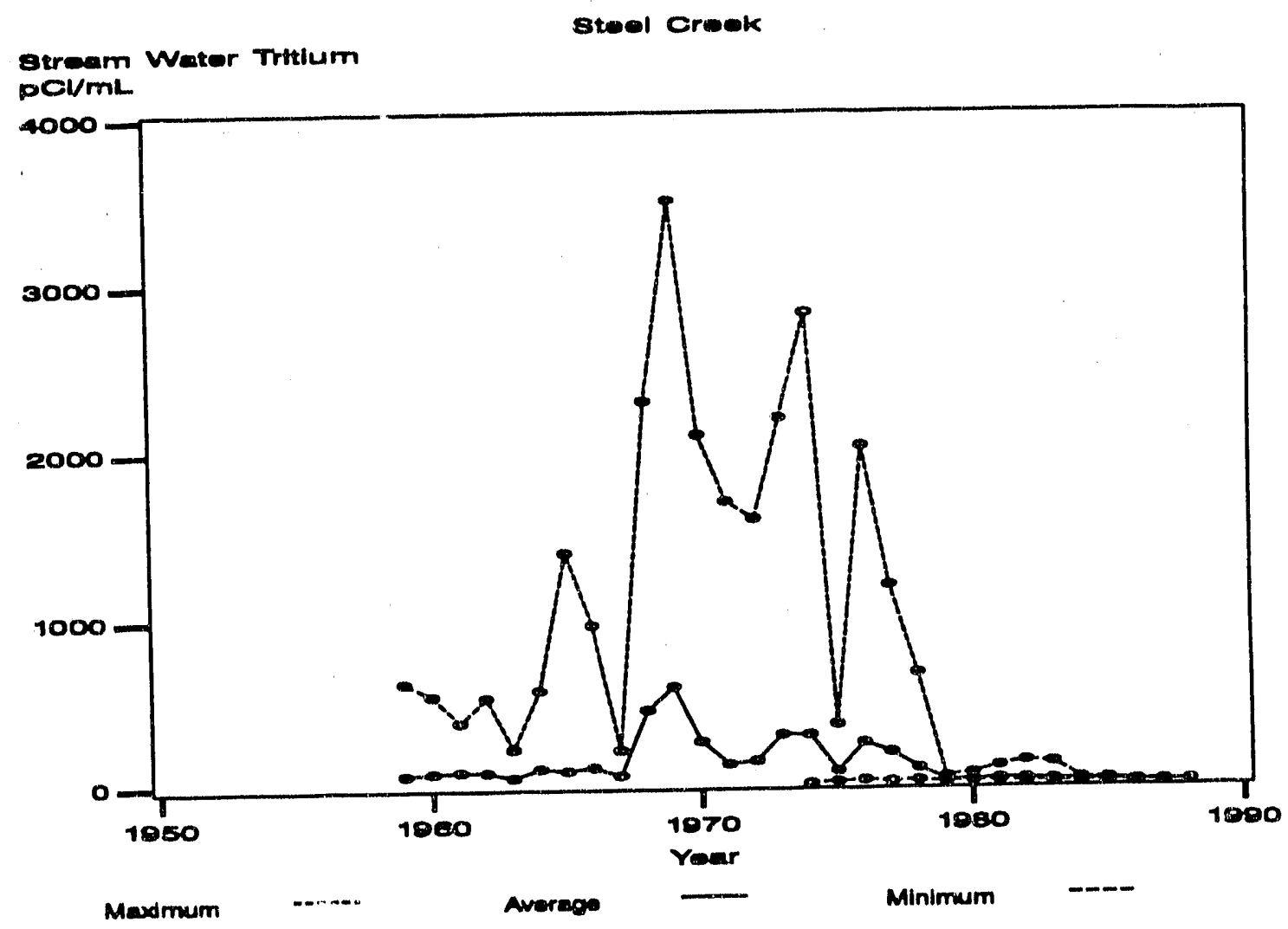

Figure 2.33. Water Tritlum Concentration Measured in Steel Creek

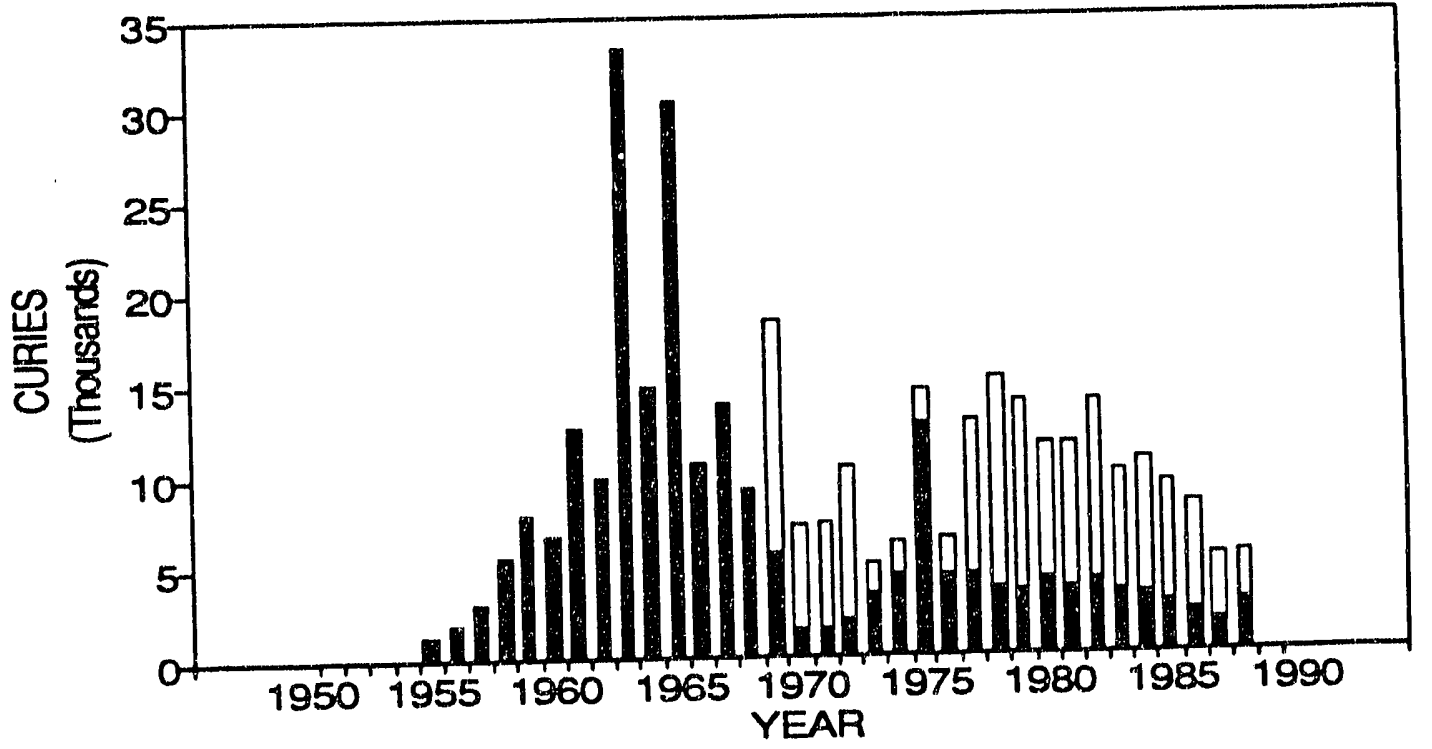

Figure 2.34. K-Reactor Area Releases to Pen Branch 


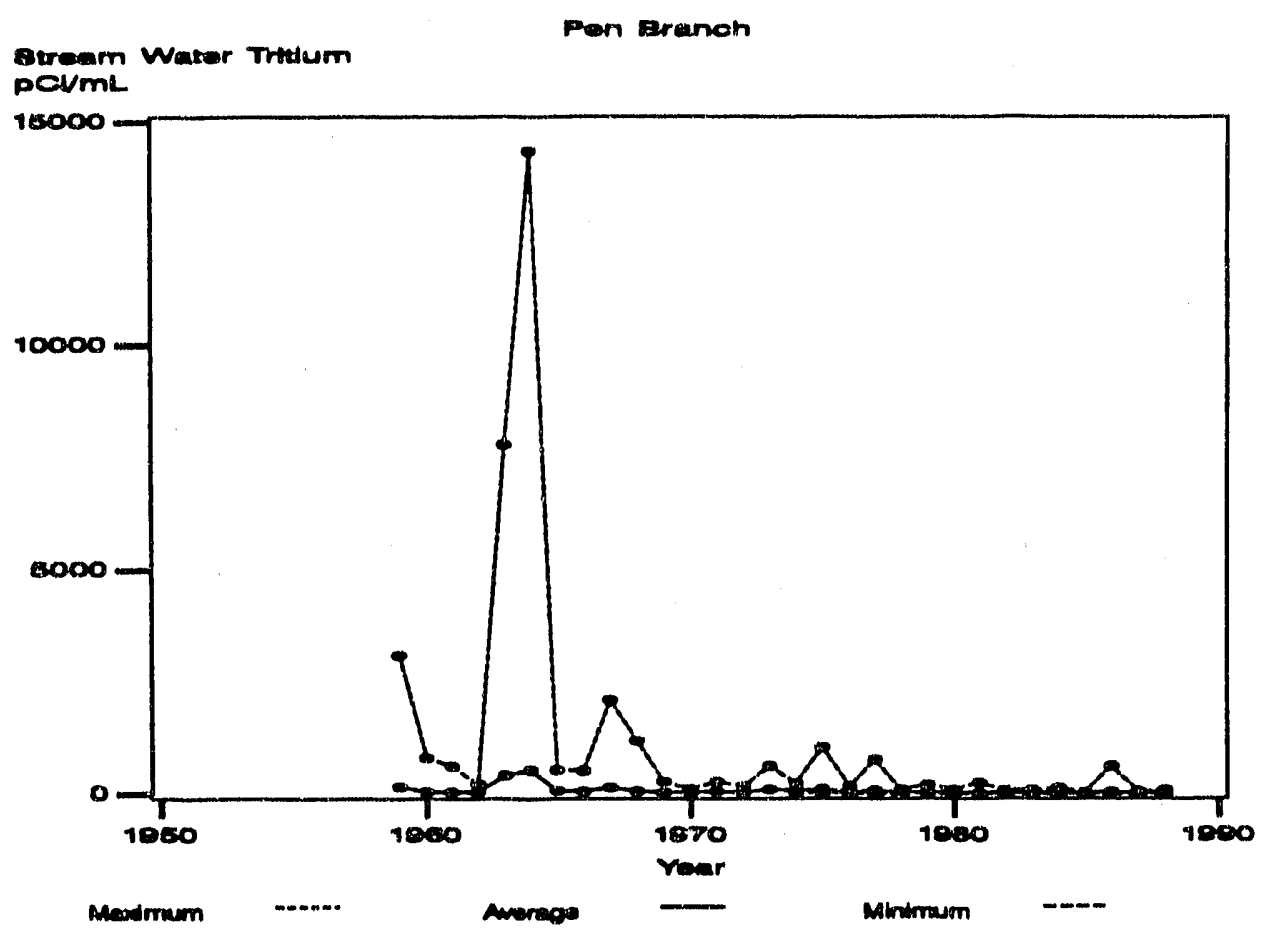

Figure 2.35. Trisium Concentrations in Pen Branch

drainage to about $20 \mathrm{tt}^{3 / \mathrm{s}}$, just above the CArea discharge stream. The flow is increased by flow from C-Reactor Area. Prior to 1986, the flow was increased to about $400 \mathrm{ft}^{3} / \mathrm{s}$ from C-Reactor cooling water. $C$ Reactor has not operated since 1985 , and the flow contribution from C Area is now about $10 \mathrm{t}^{3 / 3} \mathrm{~s}$ to Four Mile Creek. The average flow in Four Mile Creek in 1988 was about $30 \mathrm{ft} / \mathrm{s}$.

Of the $500,000 \mathrm{Ci}$ of tritium that have been released to Four Mile Creek, approximately $50 \%$ has come from direct sources, and approximately $50 \%$ has come from migration (Figure 2.36). As facility releases have decreased, migration has representeda larger fraction of the tritium in Four Mile Creek. In 1988 , greater than $99 \%$ of the $11,017 \mathrm{Ci}$ of the tritium in transport in Four Mile Creek was from migration from $\mathrm{F}$ - and $\mathrm{H}$-Area seepage basins and the Burial Ground (Table 2.6 and Figure 2.36).
Tritium concentrations are measured on composited water samples collected weekly or biweekly from a paddle wheel sampler located at Hattieville Bridge about $3.2 \mathrm{~km}$ below SC Highway 125 (SRS Road A). Tritium concentrations are measured on composited water samples collected weekly or biweekly from a paddle wheel sampler located below SC Highway 125 (SRS Road A). Tritium concentrations averaged $118 \mathrm{pCi} / \mathrm{mL}( \pm 111$ $\mathrm{pCl} / \mathrm{mL}$ ) between 1959 and 1988 . The highest weekly concentration measured was 3500 $\mathrm{pCi} / \mathrm{mL}$ in 1965 (Table 2.7 and Figure 2.37).

The average tritium concentrations in Four Mile Creek have increased since 1985 because of the reduction in flow from the shutdown of $C$ Reactor. Tritium from migration sources to Four Mile Creek has remained relatively constant since 1985, but the flow was reduced about a factor of 10 with the shutdown of C Reactor (Figure 2.36). The 


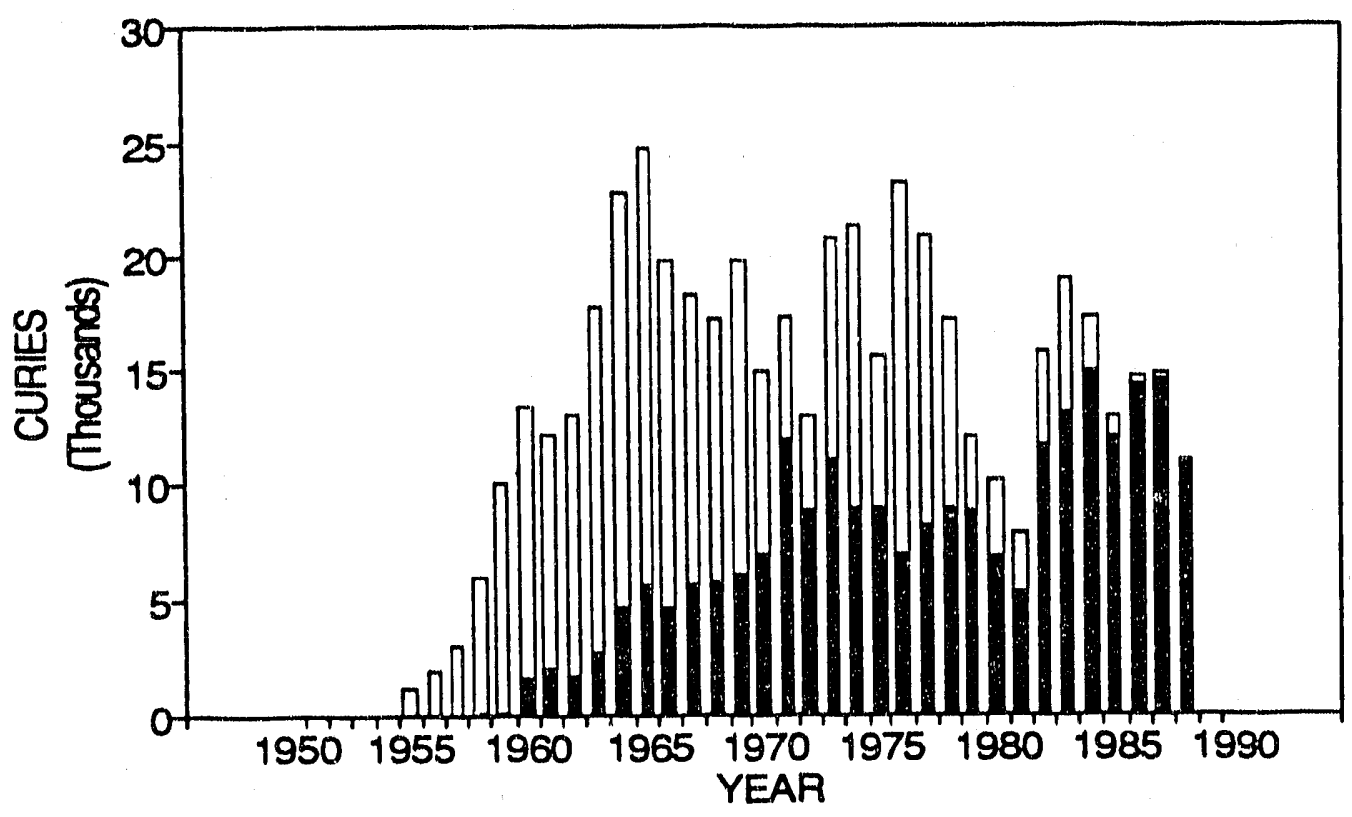

F\&HMIGRATION $\square$ C, F \& H DIRECT

Figure 2.36. F-, H-, and C-Area Releases to Four Mile Creek

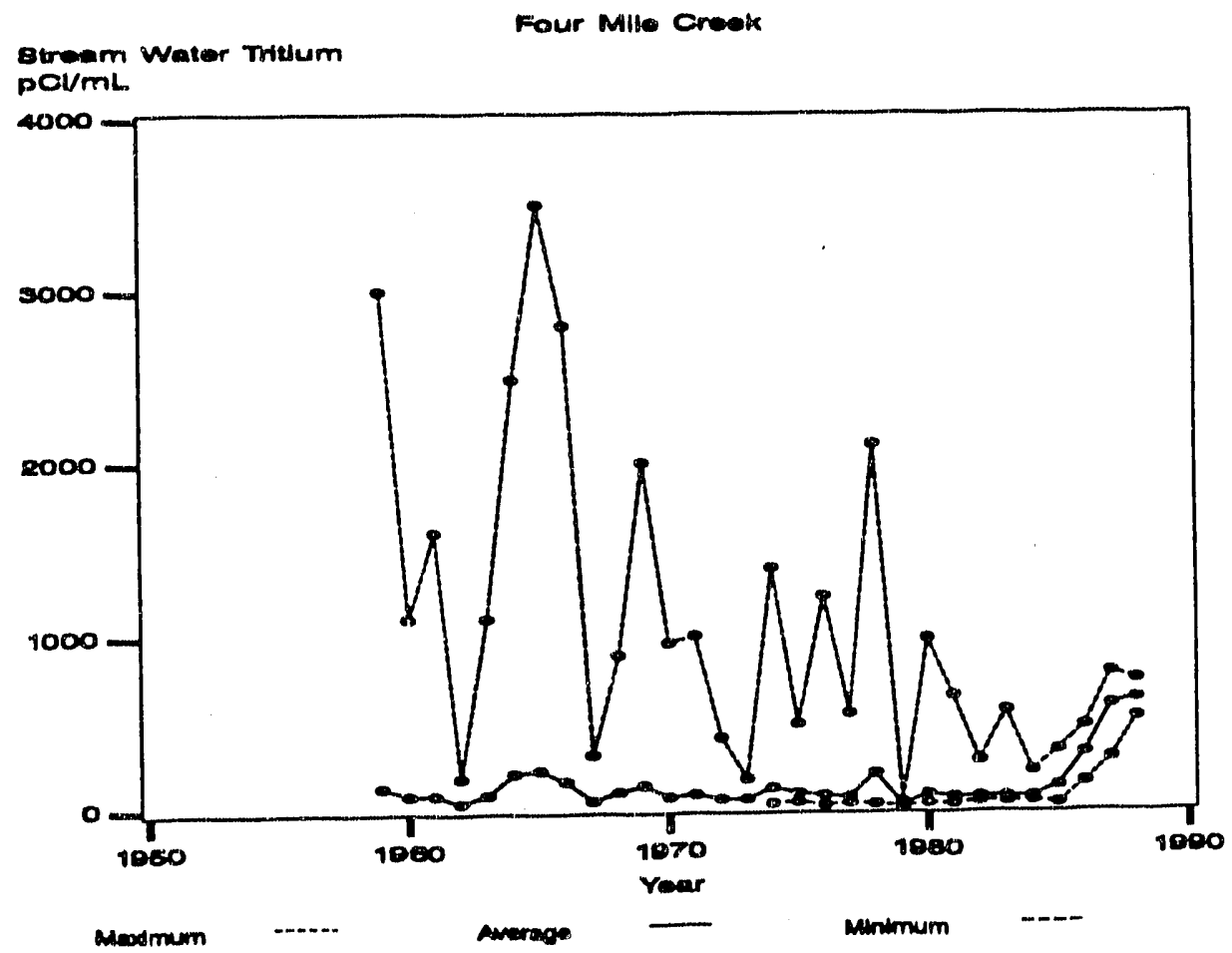

Figure 2.37. Tritium Concentrations Measured in Four Mile Creek 
highest concentration reflects releases to Four Mile Creek from C-Reactor fuel storage basin operations and the low flows during reactor shutdown.

\section{Beaver Dam Creek}

BeaverDam Creek receives tritium releases near its headwaters from the 400-Area operations. Beaver Dam Creek is the smallest of the SRS streams that discharge in the river. It is $5 \mathrm{~km}$ long with a watershed of less than 26 $\mathrm{km}^{2}$. The 400-Area operations that release tritium include the heavy water rework units, the drum wash facility, and the laboratories. These facilities have released about 145,214 $\mathrm{Ci}$ of tritium to Beaver Dam Creek since operations began in the early 1950s (Figure 2.38).

The released tritium is diluted with process water from the area and travels about $6.5 \mathrm{~km}$ before it mixes with the Savannah River. About $100 \mathrm{Ht}^{3} / \mathrm{s}$ of process water is discharged from the 400 Area (primarily from power plant operations), and this water dilutes the tritium that is released from the other 400-Area facilities. Beaver Dam Creek flow was further increased to about $200 \mathrm{tt}^{3} / \mathrm{s}$ when C Reactor was operating. (C Reactor was shut down in 1985.) About $100 \mathrm{ft}^{3} / \mathrm{s}$ of water from $C$ Reactor would flow through the swamp and combine with Beaver Dam Creek flow about $0.4 \mathrm{~km}$ above the mouth. Travel time for tritium released from the 400 Area to reach the Savannah River is about $10 \mathrm{hr}$.

Composited tritium samples are collected weekly from the paddle wheel sampler located at the 400-D effluent (see Figure 2.25) and analyzed for tritium. A summary of the tritium concentrations in Beaver Dam Creekis shown in Table 2.7 and Figure 2.39. The average tritium concentration in the Beaver Dam Creek at the 400 Area is $90 \mathrm{pCi} / \mathrm{mL}$, with an annual average range of 19 to $420 \mathrm{pCi} / \mathrm{mL}$. The highest annual average concentrations occurred in the first $3 \mathrm{yr}$ of measurement

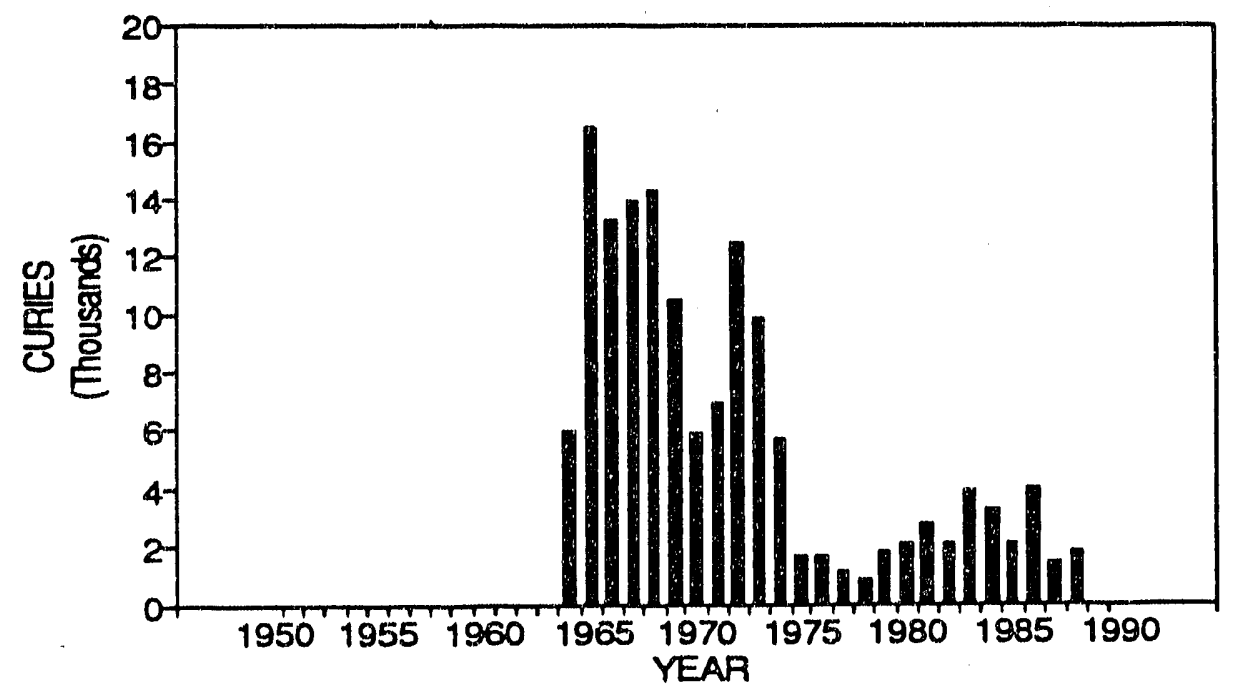

DIRECT - 400 D AREA

Figure 2.38. Tritium Releases from 400-D Area 


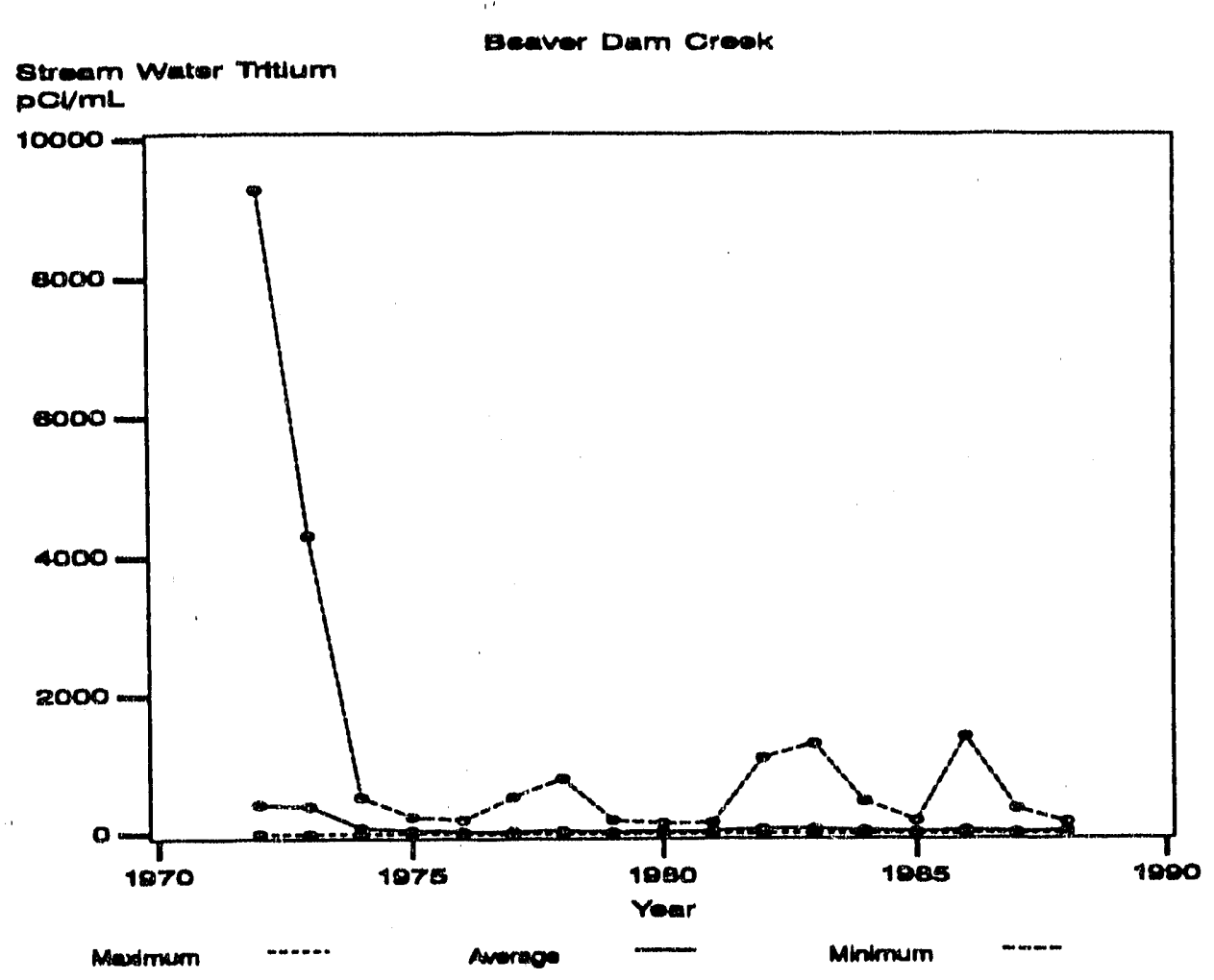

Figure 2.39. Tritium Concentrations in Beaver Dam Croek

(1972, 1973, and 1974). Since 1974, the average has decreased to $41 \mathrm{pCl} / \mathrm{mL}$ due to process operations improvement.

A process upset in 1972, in the Rework Unit, caused a release of about $4200 \mathrm{Ci}$ of tritium to the process sewer which drains into the 400-Area effluent. This release resulted in the highest recorded weekly tritium concentration in the 400-Area effluent (9274 pCi/mL).

A special study was made to measure the tritium concentrations in the Savannah River below SRS following this release (Buckner and Hayes 1975). At Highway $301,53 \mathrm{~km}$ downriver from the 400 Area, the peak tritium concentration had decreased to $280 \mathrm{pCi} / \mathrm{mL}$ (primarily due to mixing with the large flow of the Savannah River). By the time the peak had arrived in the vicinity of the watertreatment plant intakes (another $140 \mathrm{~km}$ downriver), the peak had decreased to $120 \mathrm{pCi} / \mathrm{mL}$ (Figure 2.40). The decrease downriver of Highway 301 was a result of increased river flow, dispersive dilution, and local water additions in the vicinity of the sampler, which was located near the edge of the river.

\section{Upper Three Runs Creek}

Upper Three Runs Creek is the only SRS stream with headwaters arising off the site. The stream is $40 \mathrm{~km}$ long and drains an area of about $545 \mathrm{~km}^{2}$. Its main tributaries are Tinker Creek and Tims Branch. Upper Three Runs Creek has the largest natural flow of any site stream. The average flow of $257 \mathrm{ft} / \mathrm{s}$ is slightly increased by a plant contribution of less than $10 \mathrm{tt}^{3} / \mathrm{s}$. 


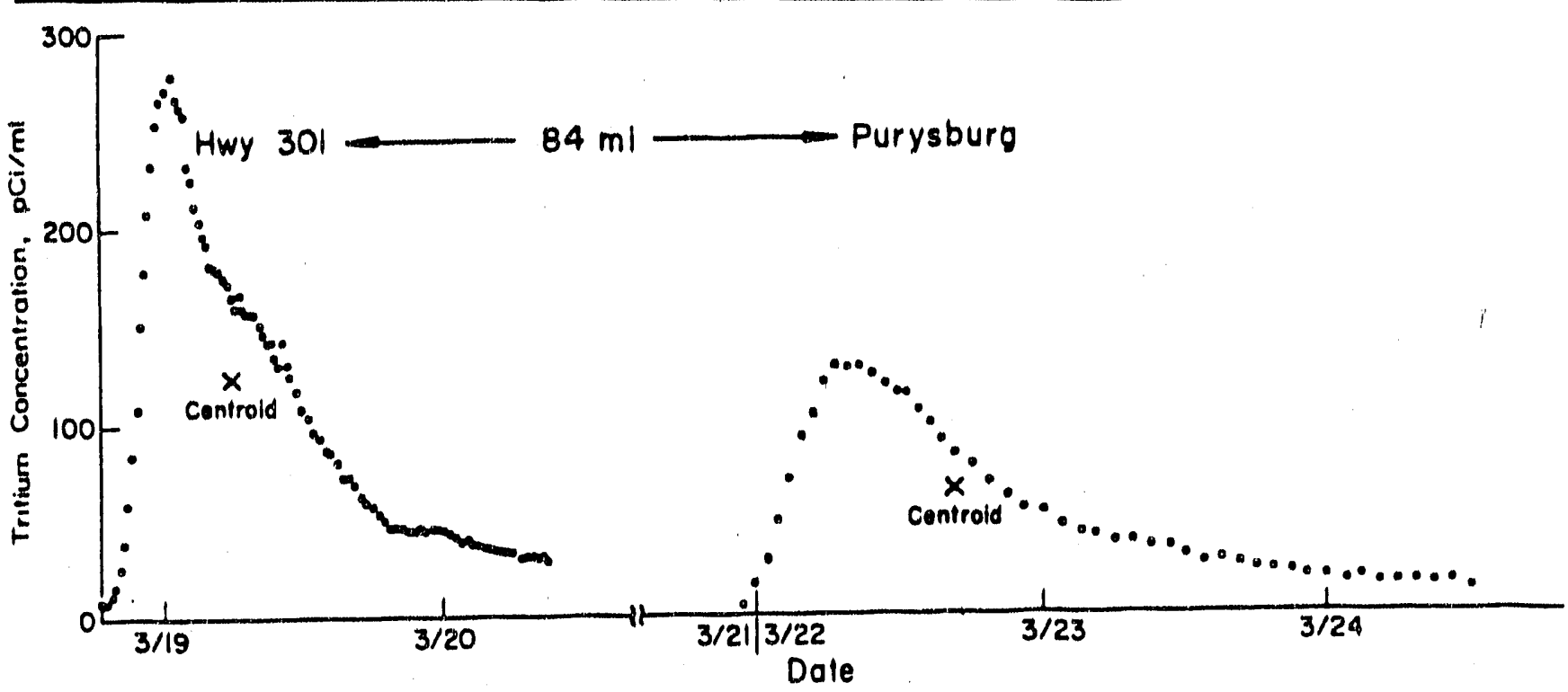

Figure 2.40. Dispersion of Tritium in the Savannah River Following a Release Through Beaver Dam Creek

SRS facilities that drain into Upper Three Runs Creek include M Area, the Savannah River Laboratory, and storm drain and ash basin flows from F Area. Until 1988, no tritium was released directly to the surface water draining these areas. Beginning in 1988, the Effluent Treatment Facility in $\mathrm{H}$ Area began releasing tritium to Upper Three Runs Creek and is expected to release about $32,000 \mathrm{Ci}$ of tritium peryear when peak operation is reached in the early $1990 \mathrm{~s}$. The release of $243 \mathrm{Cl}$ of tritium from SRL to the A-Area seepage basin is not expected to impact tritium concentrations in Upper Three Runs Creek.

Tritium concentrations are measured on composited water samples collected weekly or biweekly from a paddle wheel sampler located below SC Highway 125 (SRS Road A). Tritium concentrations averaged $3.7 \mathrm{pCi} /$ $\mathrm{mL}$ between 1959 and 1988. The highest concentration was $36 \mathrm{pCi} / \mathrm{mL}$ in 1973 (Table 2.7 and Figure 2.41). The average tritium concentration is higher than in streams or rivers at a distance from SRS, or which have tritium concentrations of less than $0.3 \mathrm{pCl} / \mathrm{mL}$, providing no nuclear facility is discharging tritium into them.

The higher tritium concentrations in Upper Three Runs Creek, as compared to background regions, are probably a result of the local washout/deposition of released SRS atmospheric tritium released onto the Upper Three Runs Creek watershed. Even though Upper Three Runs Creek did not receive SRS water discharges of tritium over this measurement period, about 24 million $\mathrm{Ci}$ of tritium were released to the atmosphere. About half of the $520 \mathrm{~km}^{2}$ of the Upper Three Runs Creek watershed is on SRS and the other half is adjacent to the boundary. Tritium atmospheric transport and cycling processes are discussed earlier in this chapter.

A general decrease in both atmospheric releases and tritium concentrations in the creek has been occurring since 1959, indicating that washout/deposition may be the source of tritium in Upper Three Runs Creek (Figure 2.41). An estimate of the 


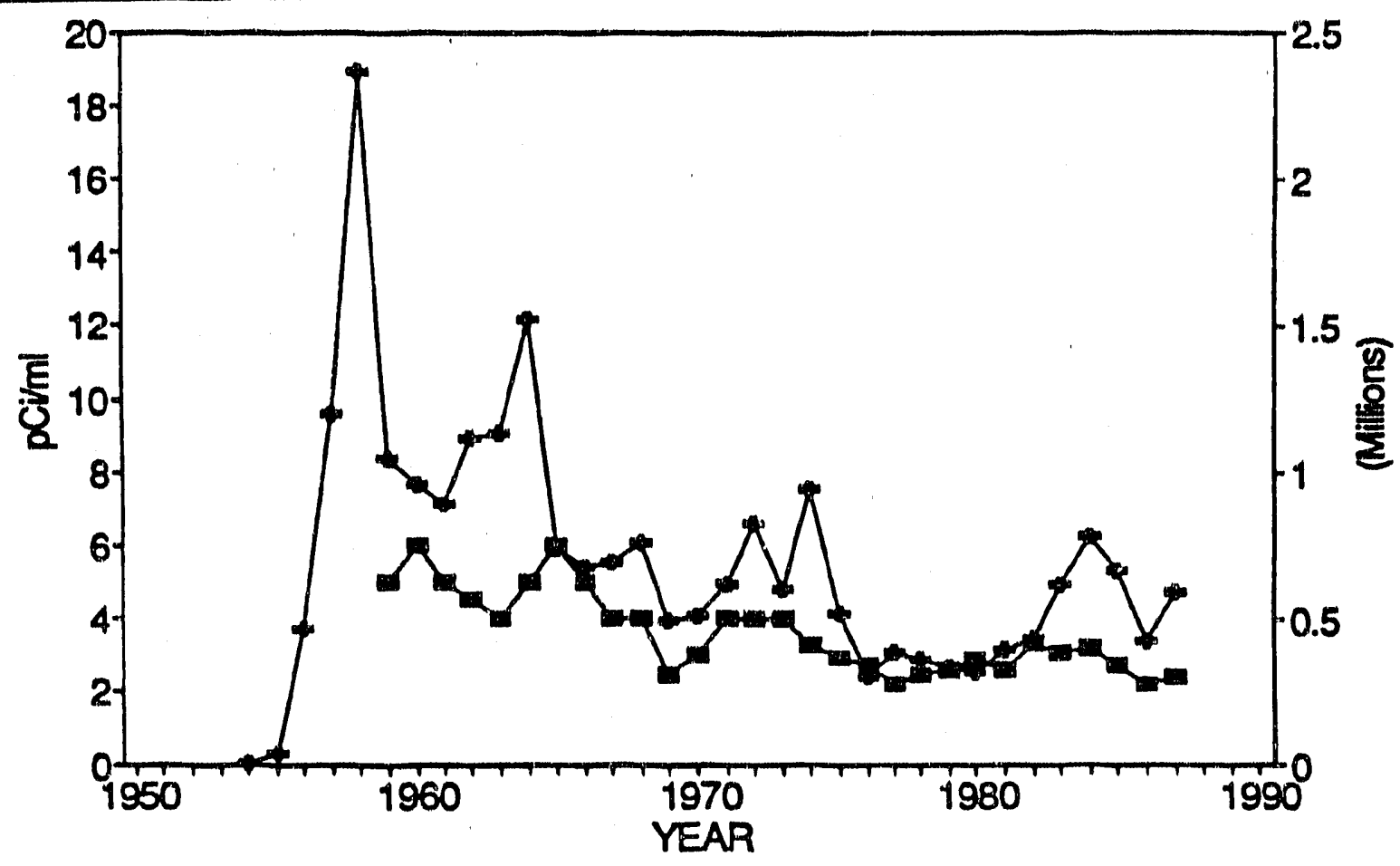

\section{$\rightarrow-$ UPPER THREE RUNS - ATMOSPHERIC RELEASE}

Figure 2.41. Tritlum Concentrations Measured in Upper Three Runs Creek Compared to Atmospheric Releases from SRS Facilities

percent of atmospheric release that is transported by Upper Three Runs can be made by comparing creek transport to SRS releases. Creek transport $(29,620 \mathrm{Ci})$ is approximately the average flow multiplied by the average tritium concentration discussed above. Only about $0.1 \%$ of the SRS atmospheric tritium releases have been transported in Upper Three Runs Creek, indicating that very little of the tritium released to the atmosphere is in the losal surface waters.

\section{Savannah River}

The Savannah River is the principal surface water system near the SRS. All SRS facilities discharge into one of the six tributaries that drain to the Savannah River. The river adjoins the SRS along its southwestern boundary for a distance of about $32 \mathrm{~km}$ and is 225 river $\mathrm{km}$ from the Atlantic Ocean. The Savannah River, drainage basin has a total area of $27,388 \mathrm{~km}^{2}$.

SRS has three pump stations on the river. Two of these pump stations supply water to cool the nuclear reactors. The smaller third pump station supplies cooling and process water for the 400 Area. Except for evaporative losses, all of the water pumped by SRS is returned to the Savannah River.

The flow of the Savannah River increases downiver of SRS. Upstream of SRS at Augusta, GA, the average flow is 10065 cfs. The average flow at Augusta, GA, has remained nearly the same, $9570 \mathrm{cfs}$, since the filling of Thurmond Lake (formerly Clarks Hill Reservoir). Flows increase between Augusta, GA, to about 12,010 cfs near Clyo, $G A$, about $161 \mathrm{~km}$ downriver. 
Titilum accounts for greater than $98 \%$ of the radloactivity in the Savannah River. From 1953 to 1988 , about 1.5 million Ci of tritium of SRS origin were in transport in the Savannah River at Highway 301 (Table 2.5). Tritium concentrations are measured on composited water samples collected weekly from paddle wheol samplers above SRS and below SRS (see Figure 2.25). The samplers above SRS are used to determine contributions upriver of SRS.

Above SRS the river averaged $0.8 \mathrm{pCi} / \mathrm{mL}$ $( \pm 1.5 \mathrm{pCl} / \mathrm{mL})$ between 1958 and 1988. The highest weekly concentration of $29 \mathrm{pCi} / \mathrm{mL}$ concentration occurred in 1960 (Table 2.7 and Figure 2.42). Most of the tritium in the river above SRS is due to fallout from nuclear weapons testing. Tritium concentrations in the river above SRS now average $<0.4 \mathrm{pCl} /$ $\mathrm{mL}$.

Below SRS, at Highway 301, SRS releases increased tritium concentrations to an average of $6.8 \mathrm{pCl} / \mathrm{mL}( \pm 3.5 \mathrm{pCl} / \mathrm{mL})$ between 1958 and 1988. The average tritium concentrations have decreased significantly since the mid1960 s due to operation and process improvements (Figure 2.43). The highest weekly concentration of $56 \mathrm{pCl} / \mathrm{mL}$ was measured in 1960 (Table 2.7 and Figure 2.43). This high concentration reflects additions from both nuclear weapons test fallout and SRS releases. The highest tritlum concentration, $280 \mathrm{pCl} / \mathrm{mL}$, was measured in a grab sample taken in the river following a tritlum release from 400 Area (Figure 2.40). The grab sample was one of many taken over several days and not composited.

As discussed in Chapter 1, relatively good agreement in the inventory of tritium measured at the point of release and the river below SRS has been observed each year since the totals have been compiled (Figure 2.44). These transport data indicate that essentially all tritium released from SRS to flowing surface waters remains soluble, except for minor evaporative losses, and is transported to the Savannah River. Comparison of measured to calculated tritium concentrations (release/ flow), shows that the annual average tritlum concentrations at Highway 301 can be calculated from annual release and average flow data (Figure 2.44).

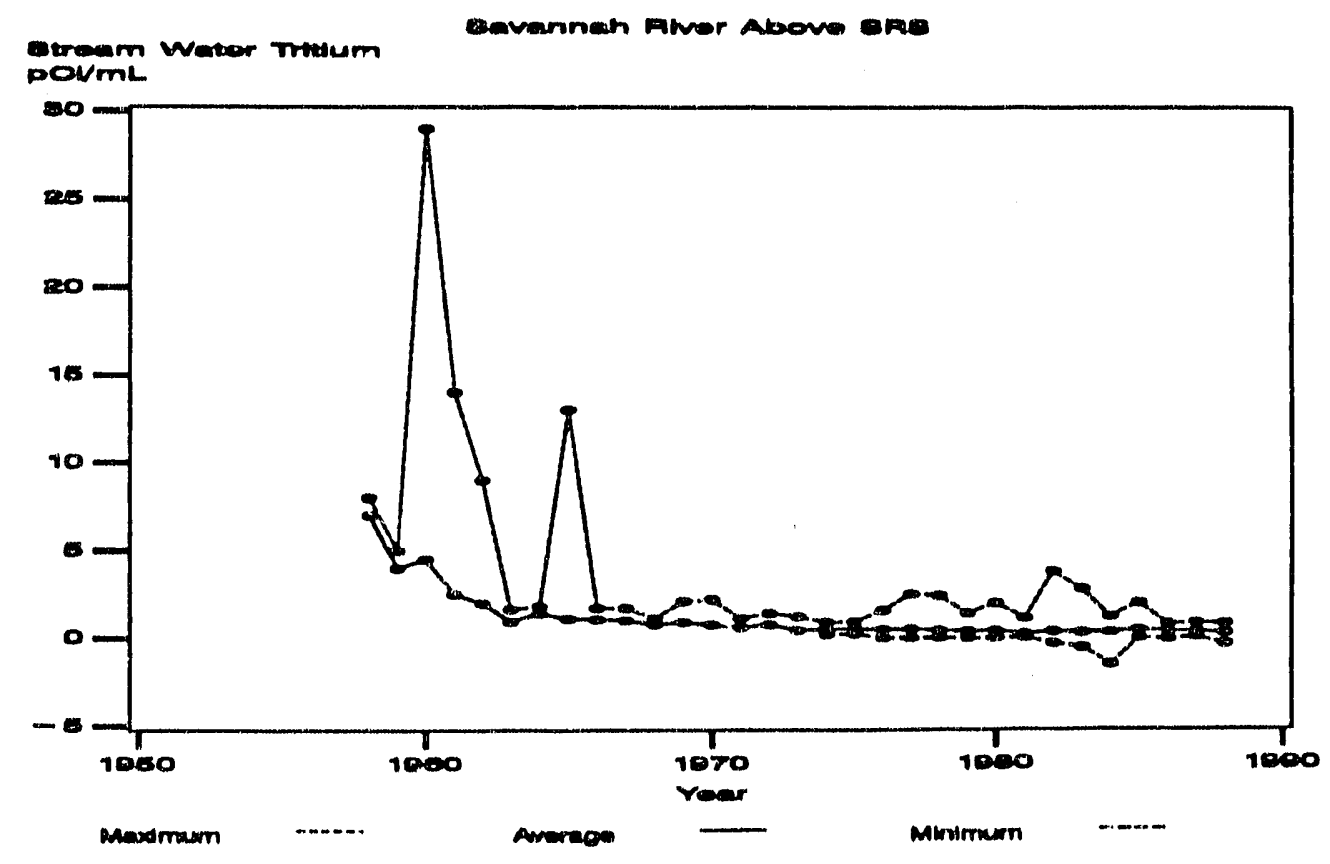

Figure 2.42. Tritium Concentrations in the Savannah River Above SRS 


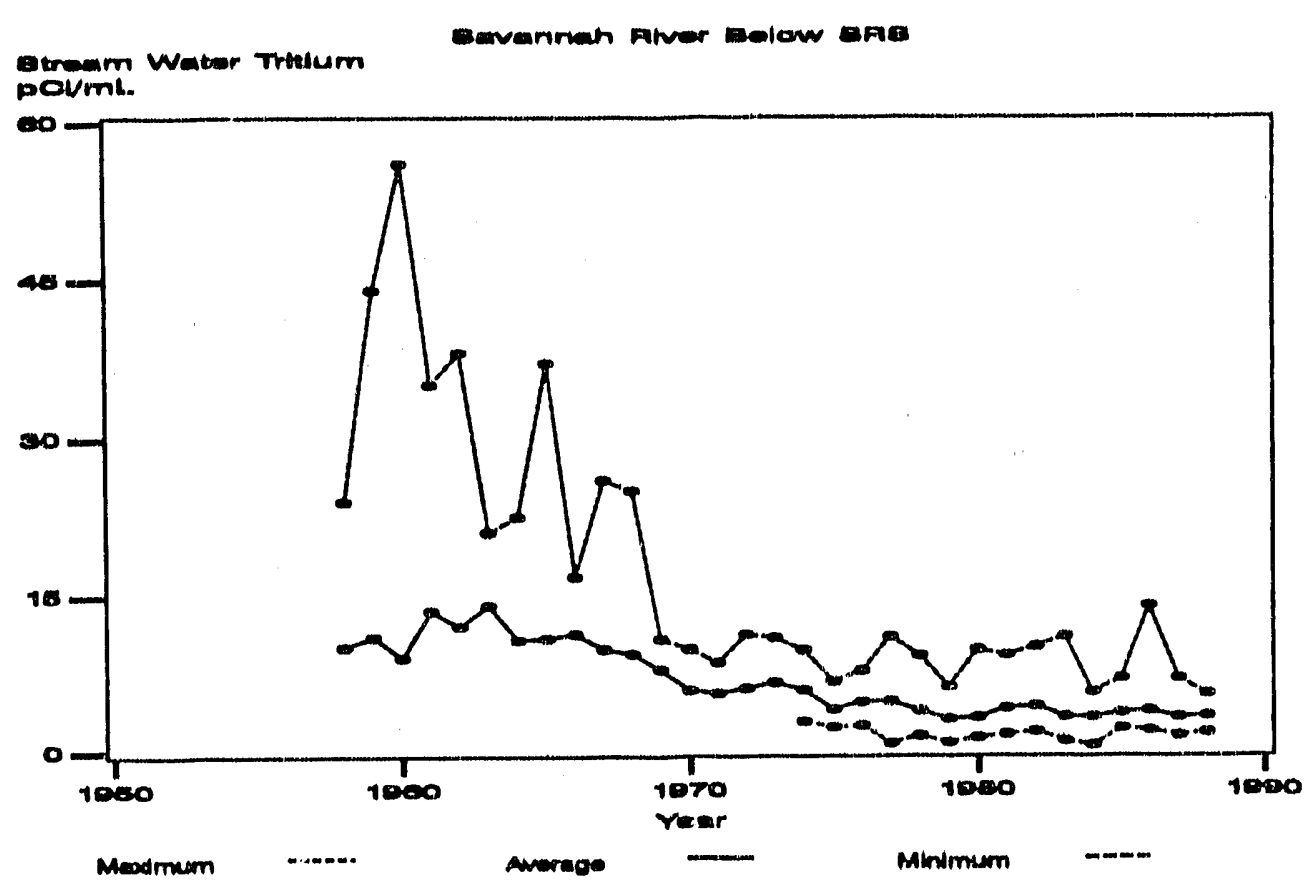

Figure 2.43. Tritium Concentrations in the Savannah River Below SRS

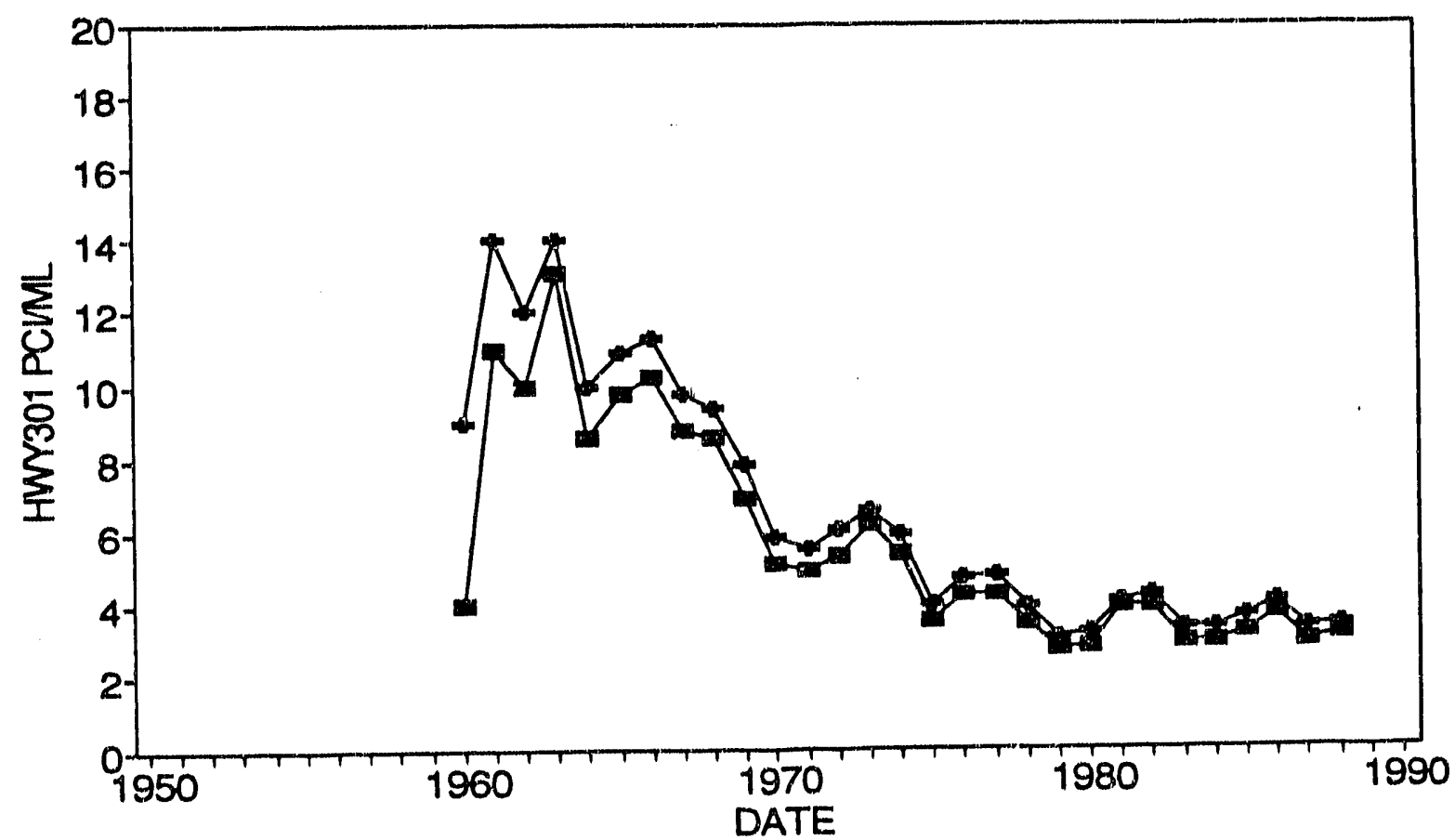

$\rightarrow-$ MEASURED CONC SRS RELEASE/FLOW

Figure 2.44. Measured Versus Calculated Tritlum Concentrations in the Savannah River Below SRS 
Each year SRS projects the maximum amount of tritium to be released to the Savannah River. Maximum individual and population doses are estlmated for these projected releases by using appropriate dose models. The dose models calculate doses by estimating the tritium concentration based on release and average annual flow rate data. Since no rellable method exists for estimating future river flows, a minimum flow of $6000 \mathrm{cts}$ (maximum individual dose) and an average of $10,000 \mathrm{cts}$ (population dose) are used to estimate the tritium concentrations in the Savannah Rlver to be used for dose calculations. (Se日 Chapter 3 for further elaboration of dose calculations.)

A comparison of the tritium concentrations measured at Highway 301 to calculated tritium concentrations (actual SRS releases divided by the minimum or average flow) for past years shows that the dose model projection method can be used rellably for tritium dose projections (Figure 2.45). The minimum flow (6000 $\mathrm{H}^{3} / \mathrm{s}$ ) overestimates the measured concentration by $60 \%$. The average flow $\left(10,000 \mathrm{ft}^{3} / \mathrm{s}\right)$ comes closer to estimating the actual concentration measured at Highway $301(5.7 \pm 2.9 \mathrm{pCl} \mathrm{mL}$ measured vs $5.5 \pm 2.4$ $\mathrm{pCl} / \mathrm{mL}$ estimated), but slightly underestimates the measured concentration by $5 \%$. On a year-to-year basis, variation around the average would be expected due to flow variation (Figure 2.45).

From Highway 301, the river water travels about $129 \mathrm{~km}$ before it is used by the Beaufort/ Jasper and Port Wentworth (City of Savannah) water treatment plants.

\section{Water Treatment Plants}

Two water treatment plants downriver from SRS supply treated Savannah River water to customers in Beaufort and dasper Counties,
SC, and Port Wentworth (parts of Chatham County), GA (Figure 2.46). The BeaufortJasper intake canal is $16.4 \mathrm{~km}$ upstream (Rlver Mile 39) of the Port Wentworth intake. Pumps at the Beaufort-Jasper pump statlon lift water into a supply canal that flows by gravity for about $29 \mathrm{~km}$ to the water treatment plant. Operation of the plant began in 1965 with a treatment capacity of about 10 million gallons per day. The Port Wentworth river water Intake is located on Abercorn Cre日k, about $3 \mathrm{~km}$ from the river, at River Mile 29. From this intake, water travels about $11 \mathrm{~km}$ through a pipeline to the plant. The plant was in operation prior to SRS startup, and its present capacity is about 45 million gallons per day.

Tritium concentrations are measured once a month in the raw water at Beaufort-Jasper and Port Wentworth water treatment plants. Each monthly sample represents a cornposite of daily water samples collected by the water treatment plant operating personnel. Sampling started at the Beaufort-Jasper water treatment plant in 1966 and at the Port Wentworth plant in 1972. Prior to 1966, tritlum concentrations at the water treatment plants were based on tritium measurements at Highway 301.

For the first several years only averages were reported. Starting in 1977, the maximum concentration at each of the plants has been included in the annual environmental report.

Water from the Beaufort-Jasper plant averaged $2.4 \pm 0.6 \mathrm{pCl} / \mathrm{mL}$ between the 1966 and 1988 time period (Figure 2.47). The highest concentration of $7.1 \mathrm{pCl} / \mathrm{mL}$ was measured in 1977.

At the Port Wentworth plant, the average was slightly higher than the Beaufort-Jasper average $(3.0 \pm 0.5 \mathrm{pCl} / \mathrm{mL})$ with a maximum 


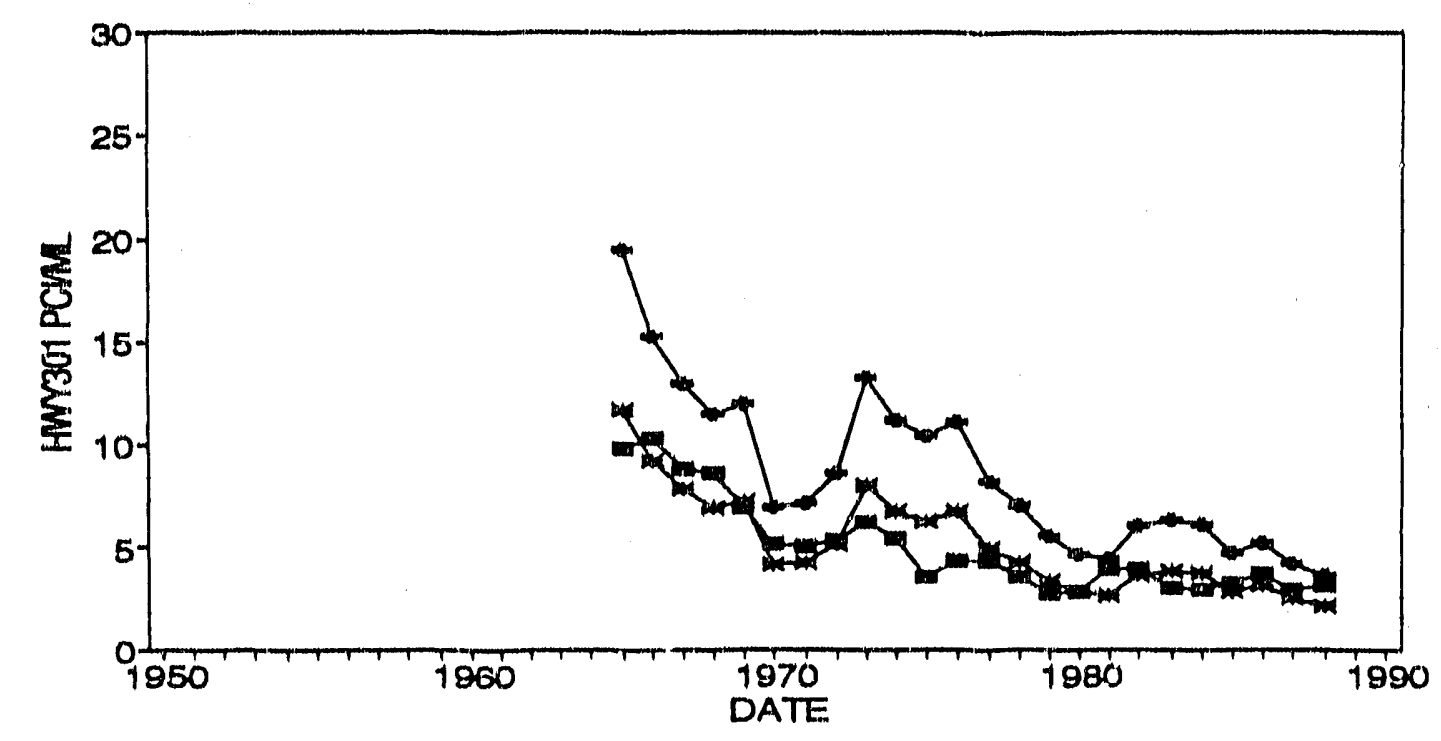

- MEASURED CONC * SRS REL 6000 CFS - SAS REL/10000 CFS

Figure 2.45. Comparison of Measured Versus Projected Tritium Concentrations in the Savannah River Below SRS

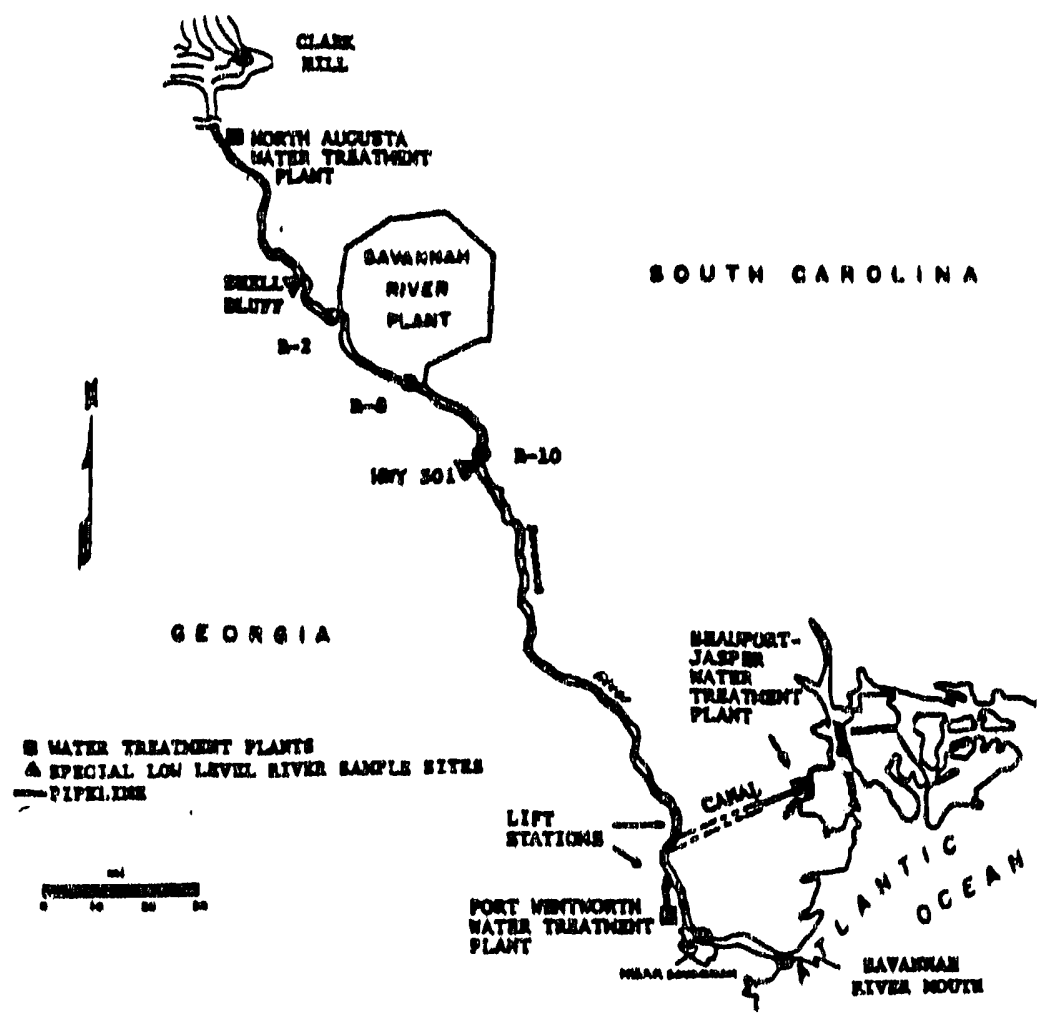

Figure 2:46: Location of Downriver Water Treatment Plants 


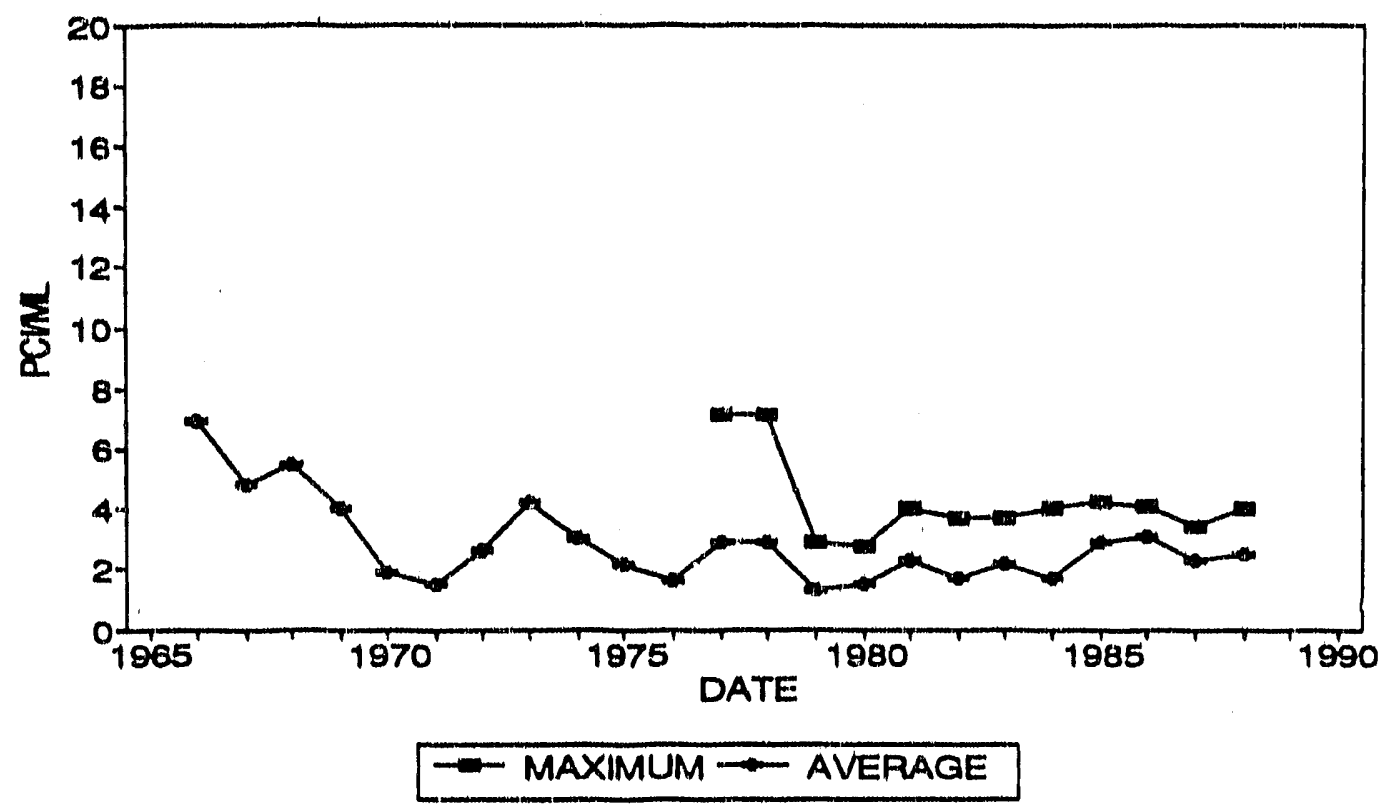

Figure 2.47. Tritlum Concentrations at the Beaufort/Jasper Water Treatment Plant

concentration of $11 \mathrm{pCl} / \mathrm{mL}$ measured in 1978 (Figure 2.48).

Tritlum concentrations decrease over the 80-mi distance between Highway 301 and the downriverwatertreatment plants (Figure 2.49). Dilution is a result of surface water and groundwater inflow into the river or supply canal and direct rainfall on the river or canal. The flow in the river increases about $20 \%$ between Highway 301 and the water treatment plants, decreasing the tritlum concentrations (Hayes 1983). Most of the $23 \%$ tritlum concentration decrease at Port Wentworth can be accounted for by this flow increase. Local water inflow from the small Abercorn Creek watershed may account for additional dilution of Savannah River water before it is pumped by the Port Wentworth pump station.

Prior to 1985, the tritium concentration decrease was much greater for BeaufortJasper $(54 \%)$ raw water than for Port
Wentworth $(23 \%)$ raw water (Figure 2.49). Entrainment of local surface waters in the Beaufort-Jasper river canal caused additional dilution. The Beaufort-Jasper pump station is located about $3 \mathrm{~km}$ from the Savannah River. Water flows to the pump station through a canal that connects with the Savannah River. Prior to 1985, a small surface stream and other local surface waters flowed into the canal and diluted the Savannah River water before it was pumped into the canal. Special water treatment problems were caused by the high organic and low suspended sediment concentrations of local coastal plain surface waiers. To reduce treatment problems, the canal was rerouted in 1985 to avold and reduce the entrainment of the local surface waters. Since 1985, tritlum concentrations at the two water treatment plants have been nearly the same (Figure 2.49).

Tritlum concentrations at Highway 301 can provide a conservative and reliable estimate 


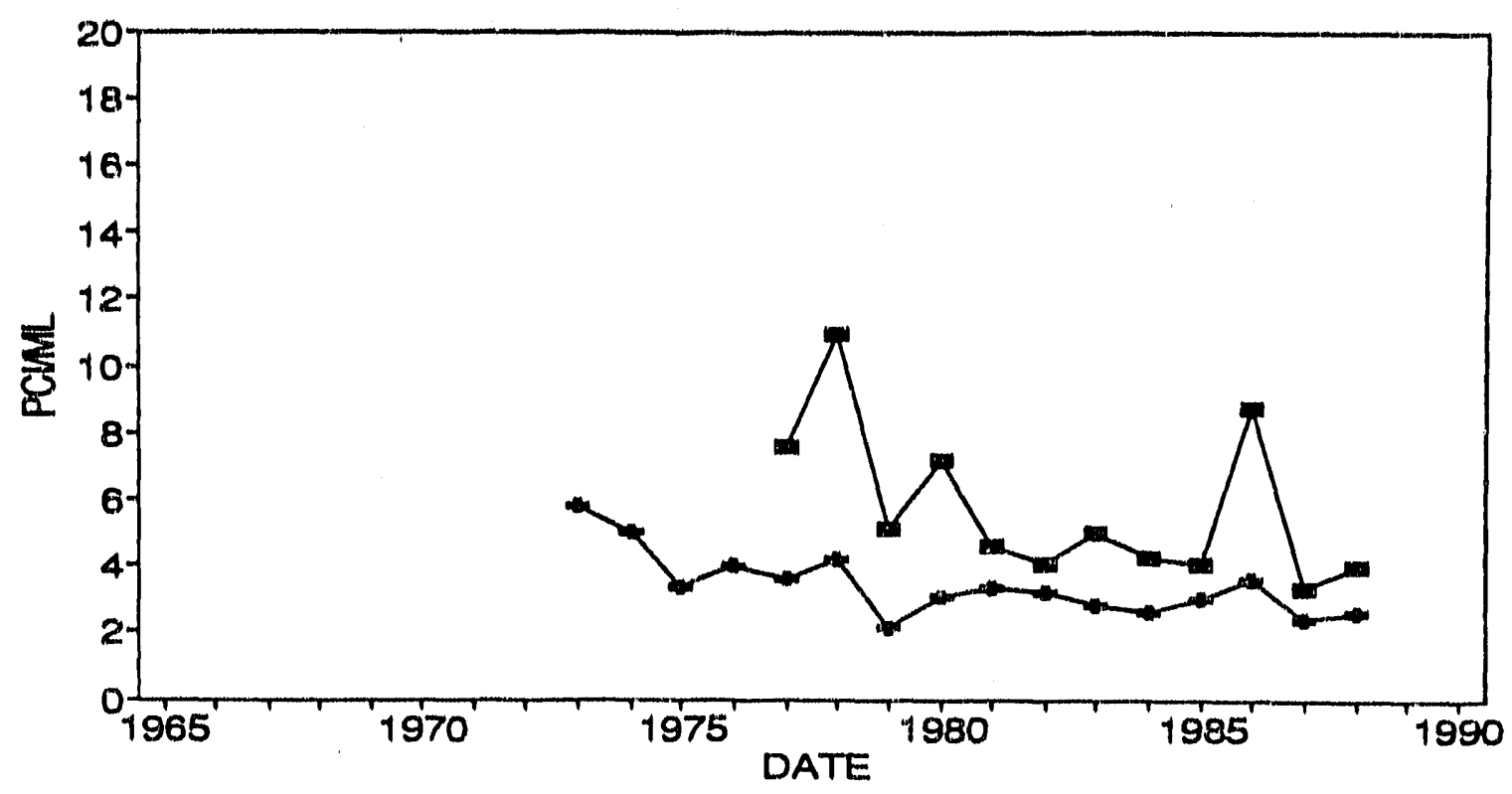

$\rightarrow$ MAXIMUM - AVEFAGE

Figure 2.48. Tritlum Concentrations at the Port Wentworth Water Treatment Plant

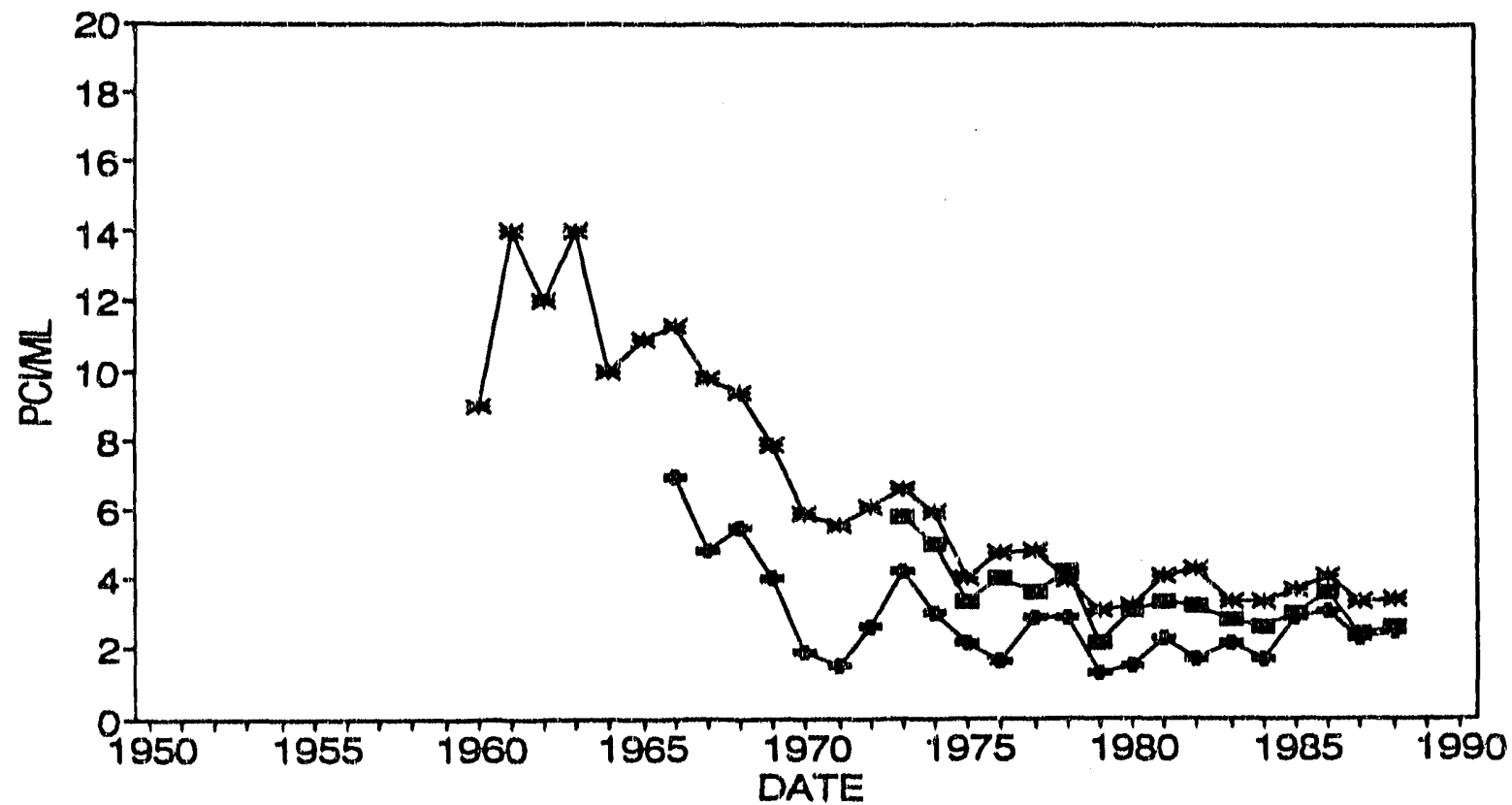

Figure 2.49. Tritlum Concentrations at Highway 301 and the Downriver Water Treatment Plants 
of concentrations downstream at the water treatment plants (Figure 2.49).

\section{Savannah River Estuary and Coastal Waters}

Special studies have been made on the transport and dilution of tritium in the Savannah River estuary and local coastal waters.

An estuary begins where sea water is measurably diluted with river water. In the Savannah River estuary, this process begins about $35 \mathrm{~km}$ upriver from the mouth. This mixing process, which dilutes the tritium concentration of Savannah River water, is more or less continuous through the length of the estuary (Figure 2.50). The linear mixing process of tritiated Savannah River water and ocean water is illustrated by the straight line in
Figure 2.51. The line was constructed from the measured tritium concentrations and salinities of surface water samples from the Savannah River estuary during a period of steady SRS tritium releases (Hayes 1975).

The linear relationship between the salinity ' and tritium content of the Savannah River water in the estuary indicates that the tritium from the river water and the dissolved salts from the ocean water are mixing at the same rate, and presumably by the mixing processes, in the estuary. This observation provides insight into the processes which dilute tritium with ocean water in the estuary. The linear relationship between tritium content and salinity also means the tritium content at any point in the estuary can be estimated on the basis of much less expensive salinity measurements.

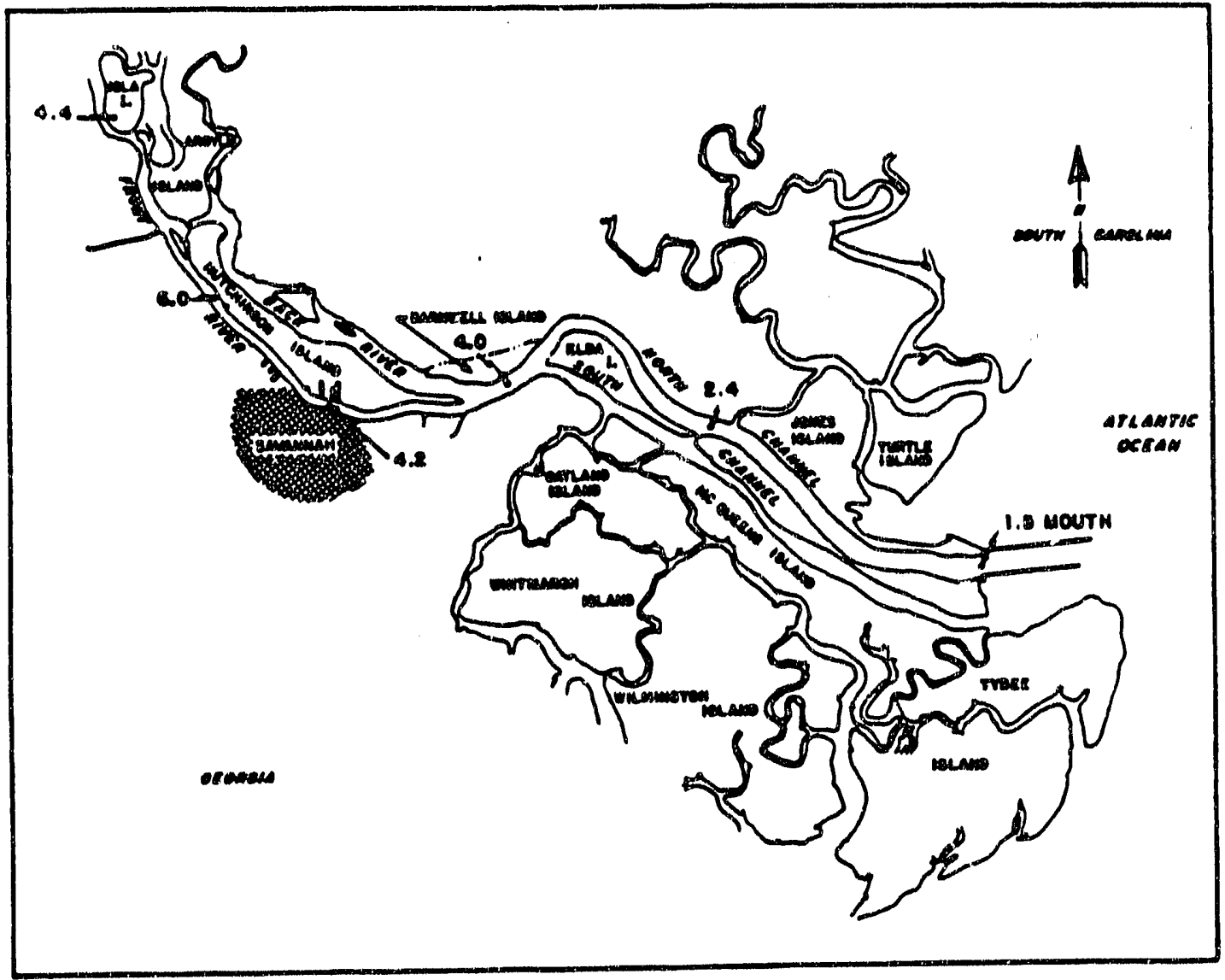

Figure 2.50. Tritium Concentrations in the Savannah River Estuary 


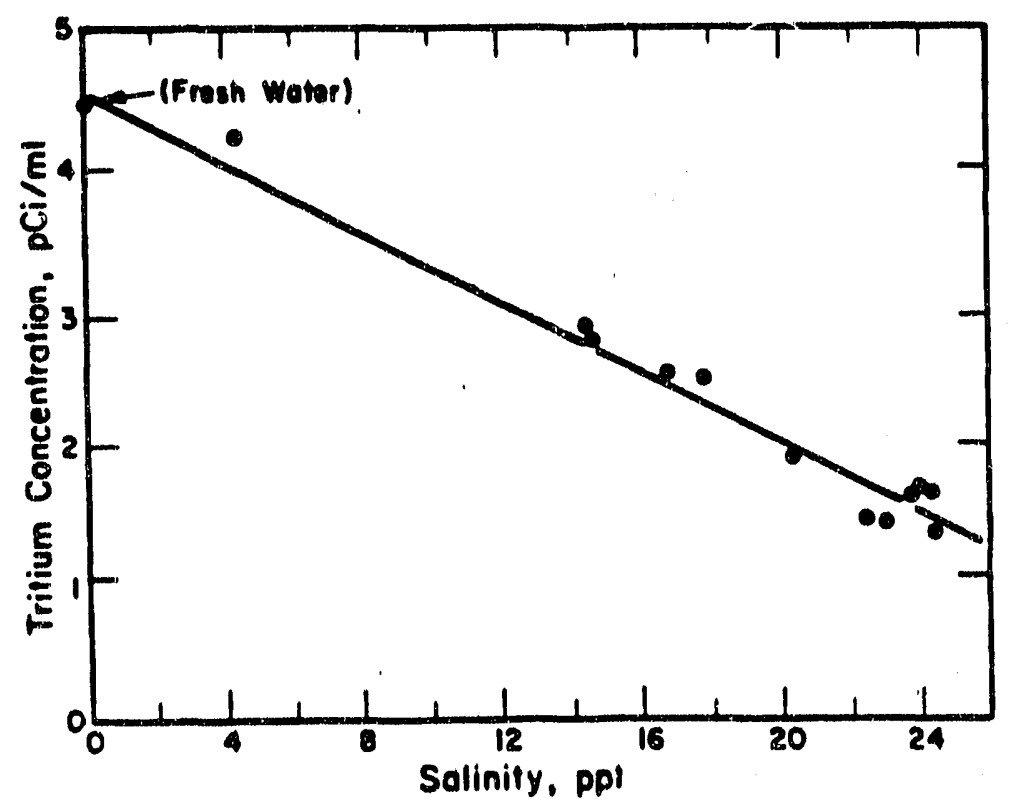

Figure 2.51. Tritium-Salinity Relatioriship in the Savannah River Estuary

Other characteristics of the Savannah River estuary that affect tritium concentrations include tidal effects and vertical stratification. The tritium concentration at any location in the estuary varies with the tide. At low tide, the salinity is the lowest and tritium concentrations would be the highest, and the converse would be true for high tide. Vertical stratification is a result of density differences between the lighter river water and the denser ocean water. This vertical stratification results in higher tritium co.rcentrations and lower salinities at or near the surface. At the mouth of the Savannah River estuary, tritium concentrations from the river have been reduced an average of about $50 \%$ by steady mixing with sea water as the river water is flushed from the estuary.

The amount of time it takes a pollutant, in this case tritium, to leave a surface water system is referred to as a flushing time. The flushing time of an estuary is a crude estimate of how long a conservative pollutant, such as tritium, would remain in an estuary. Flushing times of 2 to 3 days have been calculated for the Savannah River estuary using three different methods (Hayes 1979). The calculational methods usually underestimate the flushing time. Several simplifying assumptions are made, such as that the estuary is not stratified and constant source and flow conditions exist (Dyer 1973). If simplifying assumptions are not used to reduce the computational complexity, the calculations are extremely laborious.

\section{Coastal Waters}

Transport and mixing of the Savannah River-seawater mixture is governed by wind, tidal action, interconnecting creeks, coastal currents, fresh water flow, and Gulf Stream meanders. Depending on the local conditions, Savannah River water may be transported up or down the coast or straight out to sea. In the transport process, the Savan nah River water is mixed with more coastal water. Eventually it is flushed out to the Gulf Stream.

The mixing of Savannah River water in the local inland marine region around the Savannah River was investigated (Figure 
2.52). Surface water samples were collected in the inland marine region around the Savannah River estuary and two surrounding rivers (Coosawhatchie and Ogeechee) to determine the distribution of Savannah River water. (Samples were taken in the same week as the estuarine samples discussed earlier.) The samples were measured for tritium concentration and salt content.

Results from these measurements show the presence of tritium throughout the local coastal waters (Figure 2.52). The tritium concentration in a sample can be from any combination of the three sources: Savannah River, ocean water, or another local river. This analysis technique is limited because fresh water sources with nearly identical tritium concentrations cannot be distinguished from one another. However, the Savannah River water and ocean water components are clearly discernible, and the fact that other fresh water sources are present can be stated. Identification of the source(s) of the tritium in the water samples required an extension of the tritium-salinity graph that was used for the estuary (Figure 2.51). The graph in Figure 2.51 was extended to include the additional data from the inland marine waters and other rivers (Figure 2.53). Tritium concentrations are lower in the other two rivers, and the mixing of these river waters with sea water would fall along a mixing line different from the Savannah River line (Figure 2.53). If only two

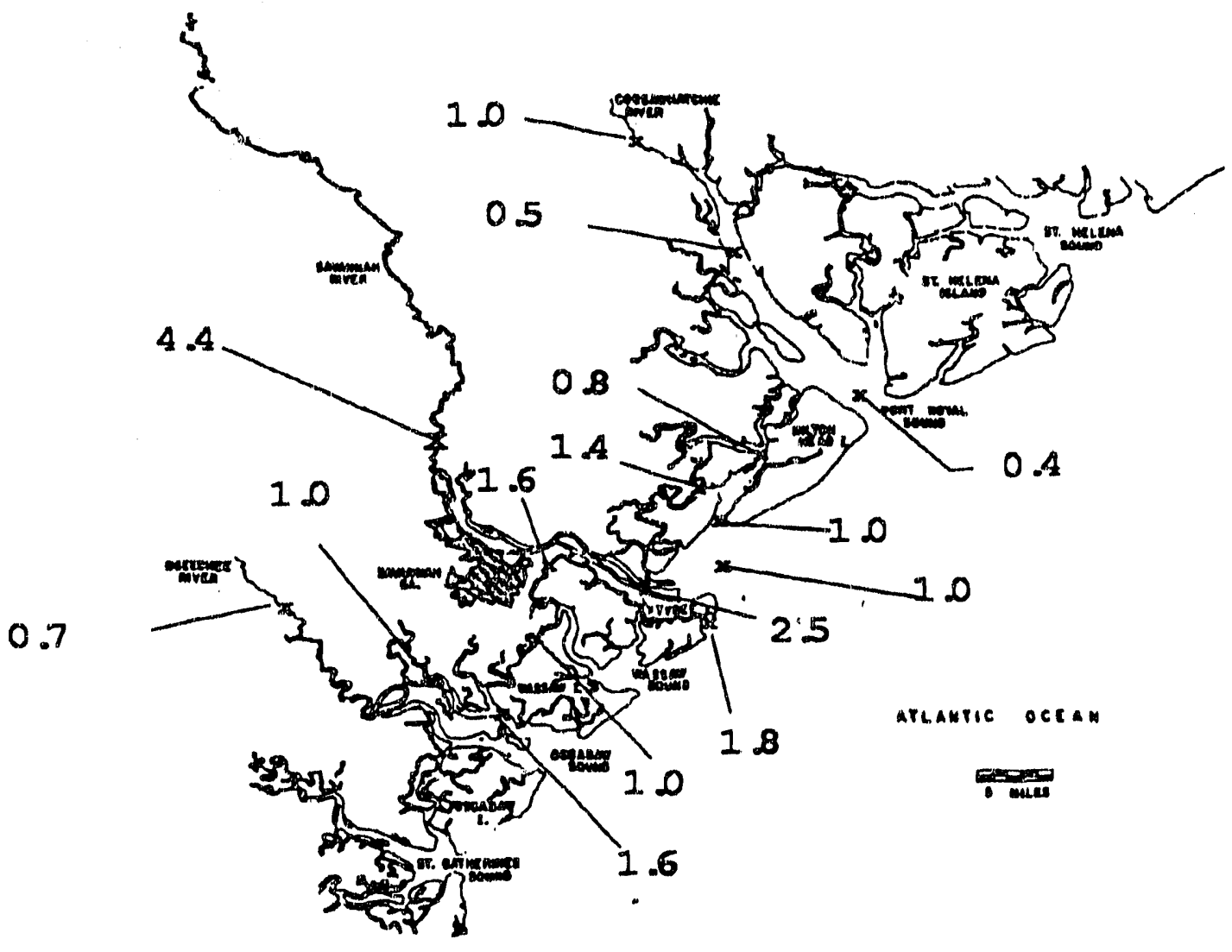

Figure 2.52. Tritlum Concentrations in Coastal Waters Around the Mouth of the Savannah River 


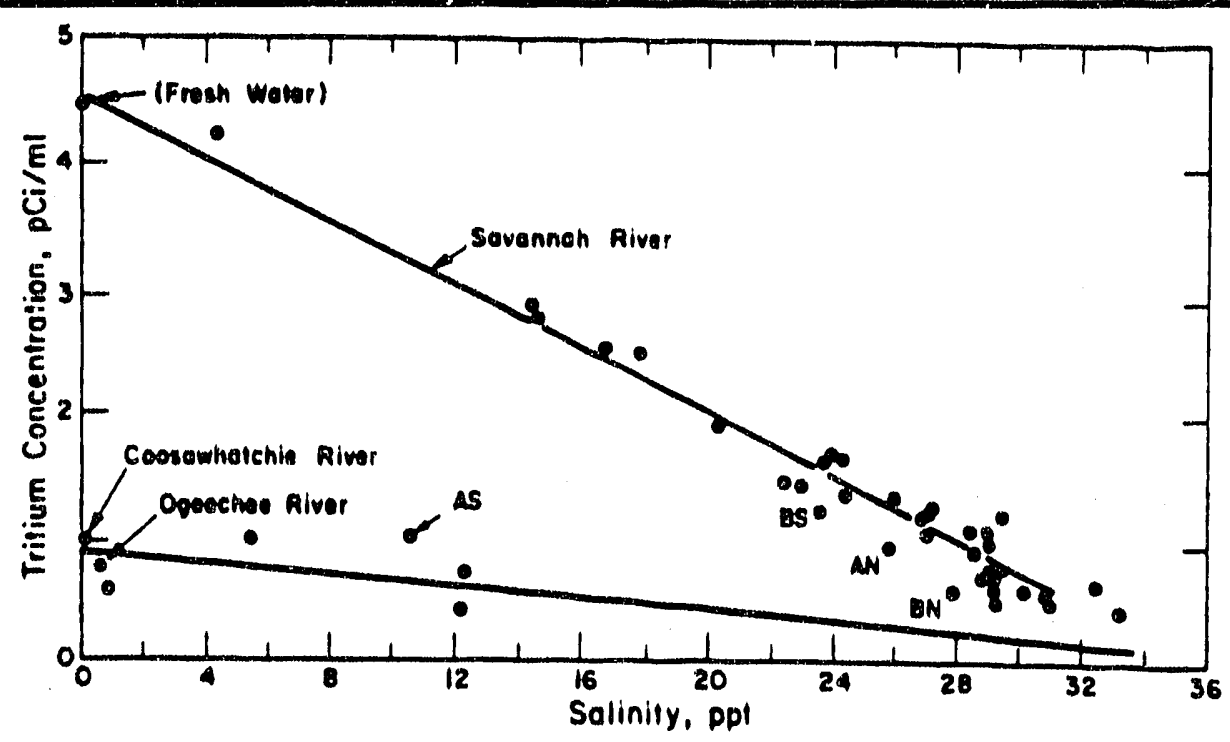

Figure 2.53. Tritlum-Salinity Relationship in Coastal Waters

sources of water were mixing (e.g. a river and ocean), then dilution would follow along that river-ocean water straight line relationship. Tritium-salinity concentration points lying between the two lines represent mixtures from the Savannah River, the other river, and ocean water.

Nearly all of the samples represented water from only two sources: one of the rivers and ocean water (Figure 2.53). Four samples appear to be mixtures of all three sources (identified as AS, BS, AN, BN in the figure). A more detailed analysis using tritium-salinity relationships showed that the two samples north of the Savannah River had nearly the same composition, and the results were averaged: estuary $74 \%$ ocean water, $12 \%$ Savannah River, and $14 \%$ other river water (this analysis method cannot distinguish the difference between the Ogeechee and Coosawhatchie River sources). The samples to the south had two different compositions. The AS sample was $29 \%$ ocean water, $14 \%$ Savannah River water, and $57 \%$ Little Ogeechee River water. The other sample, taken about $3 \mathrm{~km}$ seaward, was $64 \%$ ocean water, 26\% Savannah River water, and 10\% Little Ogeechee water. These results show that Savannah River water spreads into the local region and undergoes considerably more dilution in its transport to the coastal waters.

Savannah River water is eventually flushed to the Gulf Stream and transported out of the southeast coastal region. Estimates of the flushing time from the coastal waters vary irom 2 to 3 months, depending on the calculation method used (Atkinson, Blanton, and Haines 1978). The flushing time calculated using river input and coastal freshwatervolume is 2.7 months. The fresh water volume along the coast is estimated from salinities and total coastal water volume. A second method involving Gulf Stream meander frequency and typical coastal water entrainment dimensions produced an estimate of 2 to 3 months (Atkinson, Blanton, and Haines 1978). These estimates show that freshwater in the coastal area is moved out to the Gulf Stream where it is entrained by the large flow of the Gulf Stream of about 1 billion $\mathrm{ft}^{3 / s}$.

After the coastal water is entrained by the 
Gulf Stream waters, the tritium is further diluted as it becomes part of the complex North Atlantic Ocean circulation system. Probably all of the tritium will decay while it is in the North Atlantic circulation system.

\section{Tritium in Fish}

Special studies have been made at SRS to determine the distribution of tritium in fish. About $75 \%$ of the weight of a fish is water, and the other $25 \%$ is organic material. The water is part of the circulating water in a fish and is in tissue and organs and consists of many organic compounds, including proteins and fats. The source of the tritium in organic material is primarily from photosynthesis $\left(\mathrm{CO}_{2}\right.$ $+\mathrm{H}_{2} \mathrm{O}+$ sunlight) and secondarily from metabolic reactions. The organic compounds made during photosynthesis are the base of the food chain and undergo many additional transformations before becoming part of the organic matter in a fish. Tritium can also be incorporated by metabolic reactions, since most metabolic reactions involve water.

Special studies at SRS have been made to establish the general character of the concentration and distribution of tritium in the free water, in the tissue of fish, and in the water from which the fish were caught. Free water tritium (HTO) is part of the circulating water of the fish and can easily be removed by freeze drying. Tissue tritium is organically bound (such as to proteins, fats) and is more difficult to analyze. Organically bound tritium requires the combustion of the tissue at $800^{\circ}$ to $1000^{\circ} \mathrm{C}$ to water before tritium analysis. Special sampling and processing techniques have to be used to ensure that the tritium in the fish is neither lost nor increased during the analytical procedure.

Results from special studies in Par Pond bass at SRS show that: (1) the tritium concentration in the free water is very close to the tritium concentration in the water from which the fish was caught, suggesting that it was at equilibrium with the water [Figure 2.54]; the tritium concentration in the tissue [organic fraction] is slightly higher than the concentration of the free water tritium in the flesh [Figure 2.54]; and (3) the concentration factor for fish tissue is not large [between 1.1 and 1.75]. The source of the slightly higher tritium concentration is not known. Candidates are (1) fractionation during freeze drying of the samples [Hlayes 1982]; (2) transients caused by high tritium concentrations in Par Pond water in the past [slow turnover of organic matter in fish]; and (3) assimilation of nonphotosynthetic tritium labeled organics in the food chain.

\section{IMPACT OF SRS ON TRITIUM IN GROUNDWATER}

\section{Introduction}

There is no indication that the tritium contamination in shallowgroundwater aquifers at SRS has reached the public zone. The tritium in groundwater is generally confined to specific locations under waste management operating areas from which it travels toward surface streanis with the normal flow of groundwater.

Primary factors in the confinement of the tritium in groundwater are the size of the site and the local hydrological conditions. Because the contaminated areas are located near the center of the $753-\mathrm{km}^{2}$ site, there is a buffer zone of sufficient size to contain the tritium within the site boundaries until it outcrops into a site stream or decays to stable helium (see Figure 1.1, site map showing areas). 
PAR Pond Water and Fish

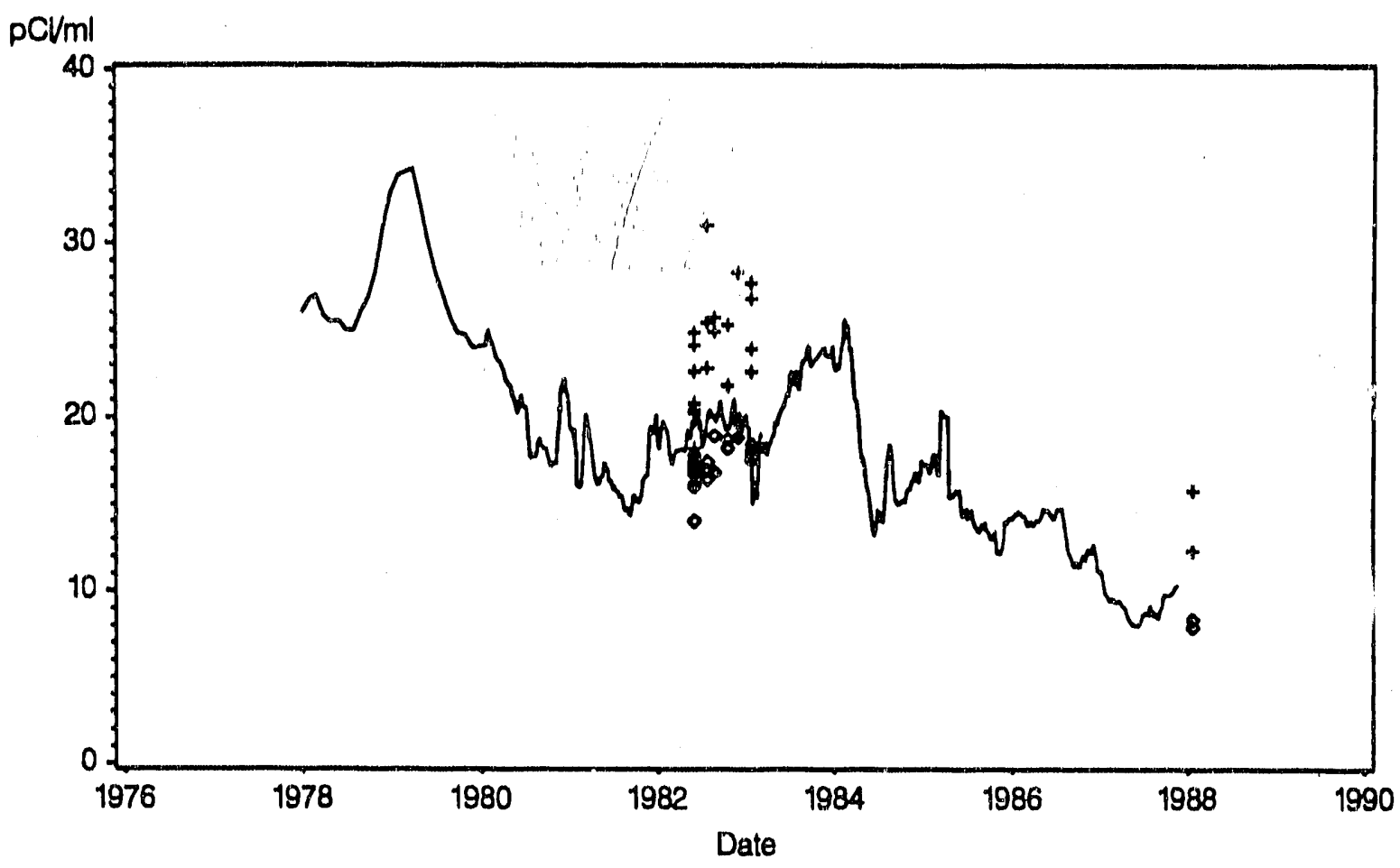

PAR Water - Fish Water $\diamond \diamond \diamond$ Fish Organic +++

Figure 2.54. Tritium Concentrations in Par Pond Water and Fish

Tritium in groundwater results from past waste disposal practices that were consistent with general industry methods from the 1950s to the early 1980s. Sources of tritium in groundwater are principally wastewater released to earthen seepage basins, buried solid wastes, and residues and leachates that have percolated through the soil to the upper groundwater aquifers. SRS waste disposal practices significantly improved in the late 1980 s with the phaseout of seepage basin usage in all nonreactor facilities and with the enhanced packaging of tritium-containing wastes that aie buried.

Tritium entering the groundwater system is transported downgradient, forming a plume within the groundwater. This type of movernent within the groundwater flow system is referred to as advection (or convection). Other mechanisms also influence the movement of tritium through the flow system. One example is hydrodynamic dispersion, which is a combination of mechanical mixing and molecular diffusion. These two dispersive processes cause a spreading of the tritium in groundwater overa larger area than advection alone would produce, resulting in a dilution of the tritium concentration. The mechanical mixing results from velocity differences produced by heterogeneities in the physical system through which the groundwater moves and the amount of winding and twisting in the path traveled. Molecular diffusion occurs as the result of the kinetic activity and is usually much less important than the effect of mechanical mixing. Essentially, tritium moves as a nonreactive constituent within the groundwater system while decaying with time. 
A comprehensive assessment of hydrological conditions and the status of groundwater contamination was recently completed for each SRS environmental site containing radioactivity. These assessments are contained in a series of environmental information documents that were completed from 1985 to 1986. A brief summary of the data contained in these documents plus additional relevant information from the annual SRS Environmental Reports will be provided in this section. The reference environmental documents contain additional information.

The sources of groundwater tritium, measurements of tritium in groundwater, transport of groundwater tritium, modeling efforts, and ultimate fate of the tritium will be discussed in the following sections for each groundwater tritium source at SRS. Unresolved issues will also be addressed where relevant.

\section{The SRS Groundwater System}

The Coastal Plain groundwater system at SRS is very complex. The geology at the site indicates a past environment where many interbedded clay, silt, and sand layers were deposited in an intricate three-dimensional flow system. The groundwater system can be divided into six main units, which are composed of several separate geologic layers (Figure 2.55).

At the base of the groundwater system is a dense clay which retards the movement of water (an aquitard). Overlying this layer is the region of loosely packed sediments laid down during the Cretaceous period (formerly referred to as the Tuscaloosa). The

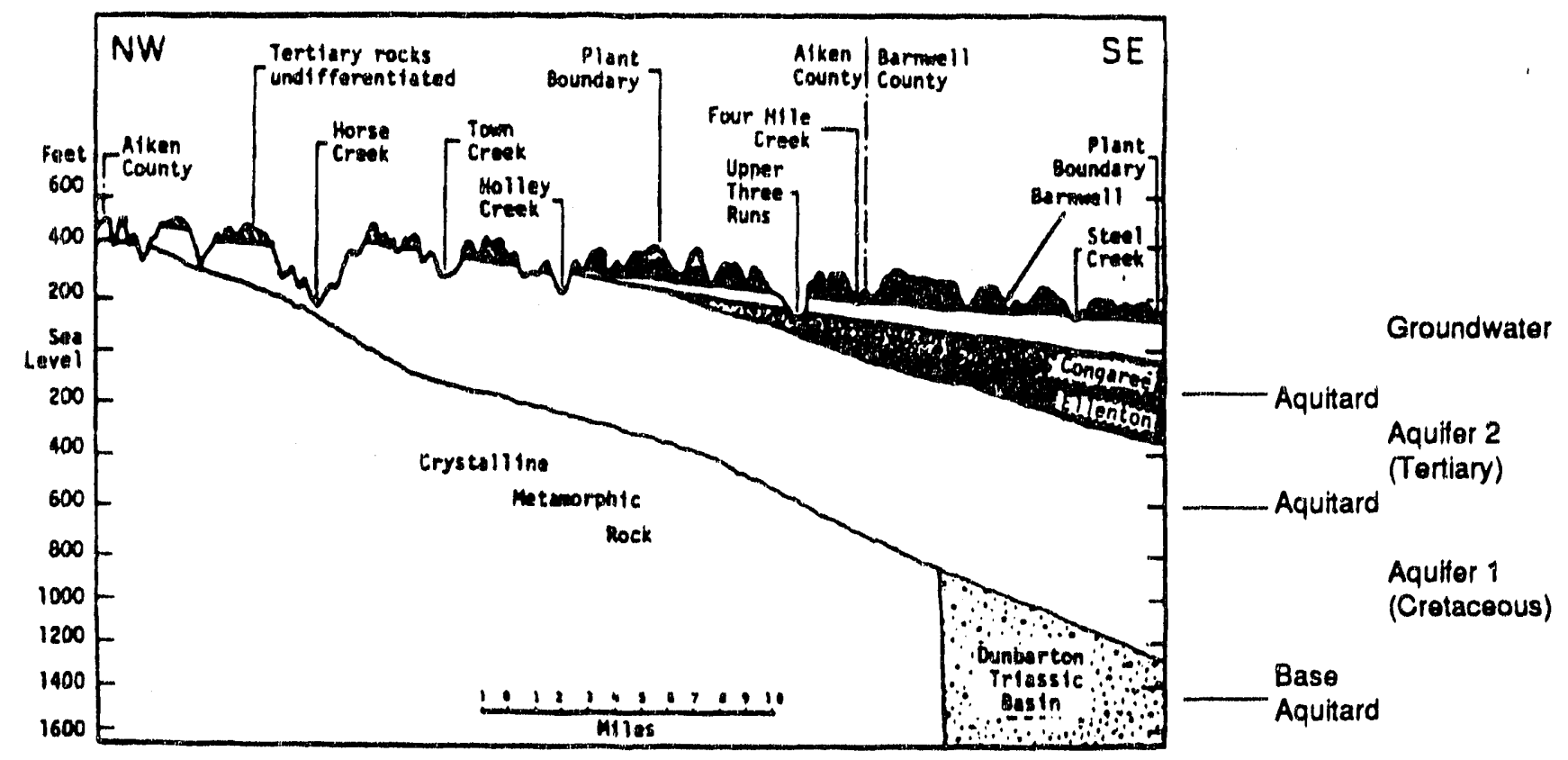

Figure 2.55. Geologic Cross-Section Showing the Main Aquifers 
Cretaceous unit is an excellent source of water and can sustain yields of $63 \mathrm{~L} / \mathrm{sec}$.

The upper 6-m section of the Steel Creek layer and the entire Ellenton layer are composed of thick silty clay material that forms a 30-m, leaky aquitard unit above the Cretaceous aquifer. Overlying this aquitard is a tertiary-age aquifer. This unit is approximately $30-\mathrm{m}$ thick, consisting predominantly of fine-to-medium and mediumto-coarse, well-sorted sands. The Tertiary aquifer is not nearly as prolific as the Cretaceous aquiler below it but can sustain yields up to $6.3 \mathrm{~L} / \mathrm{sec}$ in water supply wells.

Overlying the Tertiary aquifer is a $15-\mathrm{m}$ depositional layer which acts as a leaky aquitard unit. This unit is often referred to as the "green clay", a local designation in early documents because of the color of the glauconite interbedded in this layer. Overlying this unit is the water table unit which extends to the surface. The water table unit is not an aquifer by strict definition because of its low water-producing capabilities. Several wells in the water table at SRS cannot produce 0.06 $\mathrm{L} / \mathrm{s}$ for a substantial period of time. Nevertheless, it is a distinct and important groundwater unit because any aquifer contamination from tritium or other materials entering at the surface must flow through the water table unit before entering other groundwater units or discharging to surface waters. The thickness of the water table varies greatly across the site due to the changing topography. It can be as low as zero where soil has been eroded away by a stream or as deep as $61 \mathrm{~m}$.

In some areas it is necessary to modify the units defined above because of local features. For example, to effectively describe the groundwater system in the northern part of the SRS, it is necessary to divide the water table unit into three units consisting of an aquitard (referred to locally as the "tan clay") between two units with groundwater characteristics like the single water table unit. At K-, L-, and P-Reactor areas, in the southern portion of the site, evidence from core descriptions and geophysical logs indicate that the tan clay is very sporadic and thin in these areas and is, therefore, not a consistent unit.

\section{F-Area Seepage Basins}

The F-Area seepage basins are located in the central portion of SRS, west of Road C and opposite Road $E$ (Figure 2.56), approximately $8 \mathrm{~km}$ from the nearest site boundary. The basins are at an elevation of about $85 \mathrm{~m}$ and approximately $610 \mathrm{~m}$ northwest of Four Mile Creek and $1830 \mathrm{~m}$ southwest of Upper Three Runs Creek. The bottom surface of the three F-Area basins covers approximately $22,000 \mathrm{~m}^{2}$. The three F-Area basins have a combined capacity of about $109,000 \mathrm{~m}^{3}$ at overflow conditions. From 1955 to 1988, the F-Area seepage basins. routinely received wastewater containing some tritium from the F-Area separations facilities. The purpose of these basins was to delay the release of tritium to surface streams by using the scil column and groundwater pathways.

The wastewater entered the basins through a single underground pipeline into Basin 1. Wastewater then flowed from Basin 1 to Basin 2 and Basin 3 through underground pipelines. The average daily flow to the F-Area seepage basins, measured upstream of the basins in 1985 , was $411 \mathrm{~m}^{3} /$ day. The basins were taken out of service in December 1988 and no longer receive wastewater.

Groundwater has been monitored for 


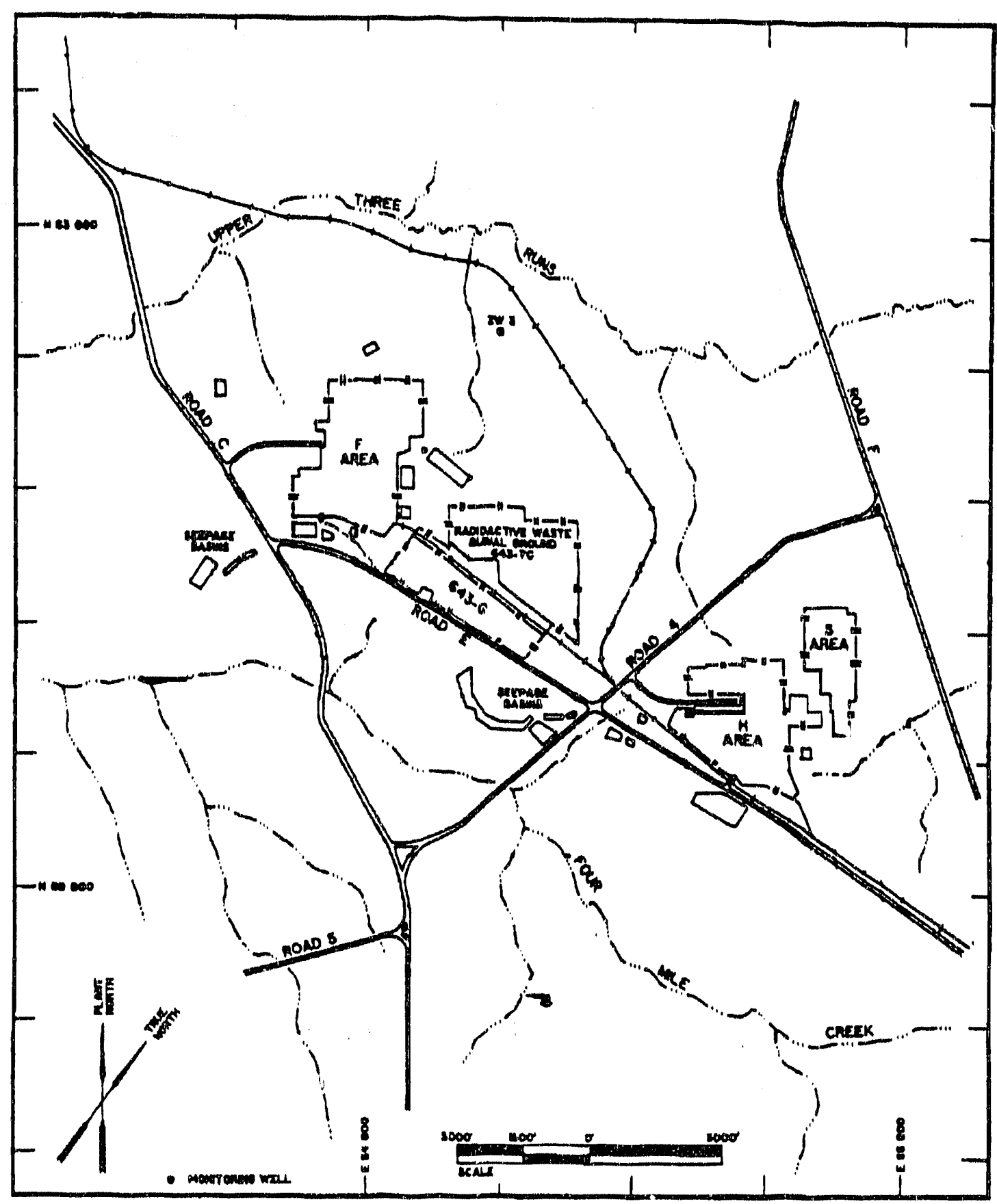

Figure 2.56. L.ocation of F- and H-Area Seepage Basins on the High Ground Between Upper Three Runs and Four Mile Creeks 
tritlum since basin startup in 1955. Tritlum accounts for $99 \%$ of the radioactlvity in the basins. The cumulative original release of tritium is estimated to be $270,000 \mathrm{Cl}$, and the decay-corrected release through 1985 is $150,000 \mathrm{Cl}$. Monitoring programs have defined the plume of tritlum emanating from the F-Area seepage basins in the water table (Figure 2.57). This plume was investigated to determine its horizontal and vertical extent. Figure 2.58 shows the results of this investigation. Recharge from rainfall drives the maximum concentrations below the water table in the area between the basins and Four Mille Creek. Discharge to the creek then permits the maximum concentrations to rise again to the water table in the vicinity of the creek. This explains the outcrop concentration of $40,000 \mathrm{pCi} / \mathrm{L}$. of tritium within the area between the 1000 and $10,000 \mathrm{pCi} / \mathrm{L}$ contours shown In Figule 2.58. The average tritlum concentrations from wells located around the seepage basins for the years 1982 to 1988 are given in Table 2.8.

Water flow at the basins is generally downward through the unsaturated zone to the water table. When this vertical flow from the seepage basin reaches the water table, the flow path is generally downward and horizontal toward Four Mile Creek. The average gradlent between Basin 3 and Four Mile Creek is approximately $0.014 \mathrm{~m} / \mathrm{m}$.

Most of the flow from the F-Area basins to Four Mile Creek is from Basin 3. The first wells, in what was later defined as the main flow path, were installed during 1962. One of these, well F19 (Figure 2.59), had very low concentrations of tritium until July 1963 . The

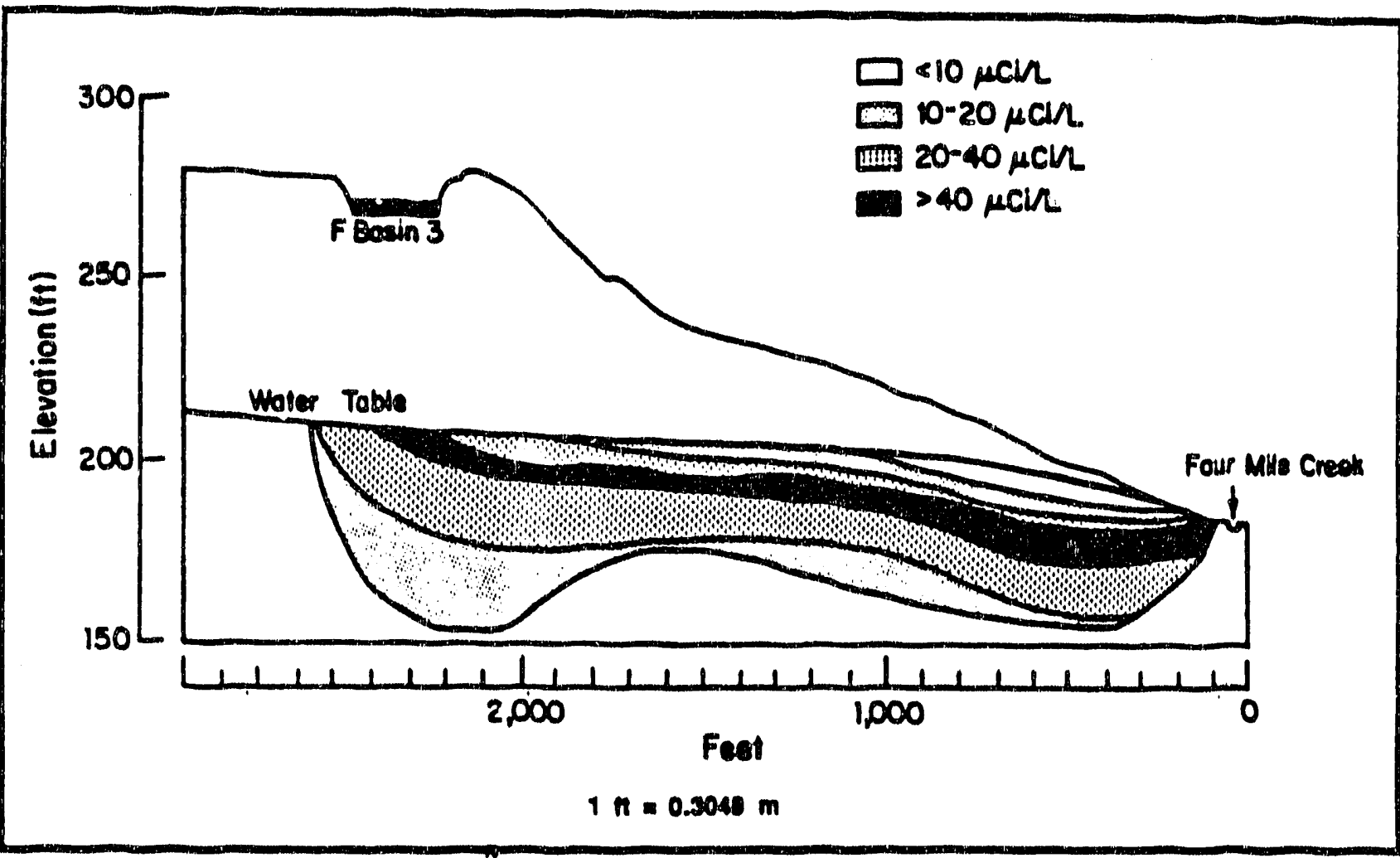

Figure 2.57. Vertical Distribution of Tritium in Groundwater along a North-South Cross Šection under F-Ärea Seepage Basin $\overline{3}$ 


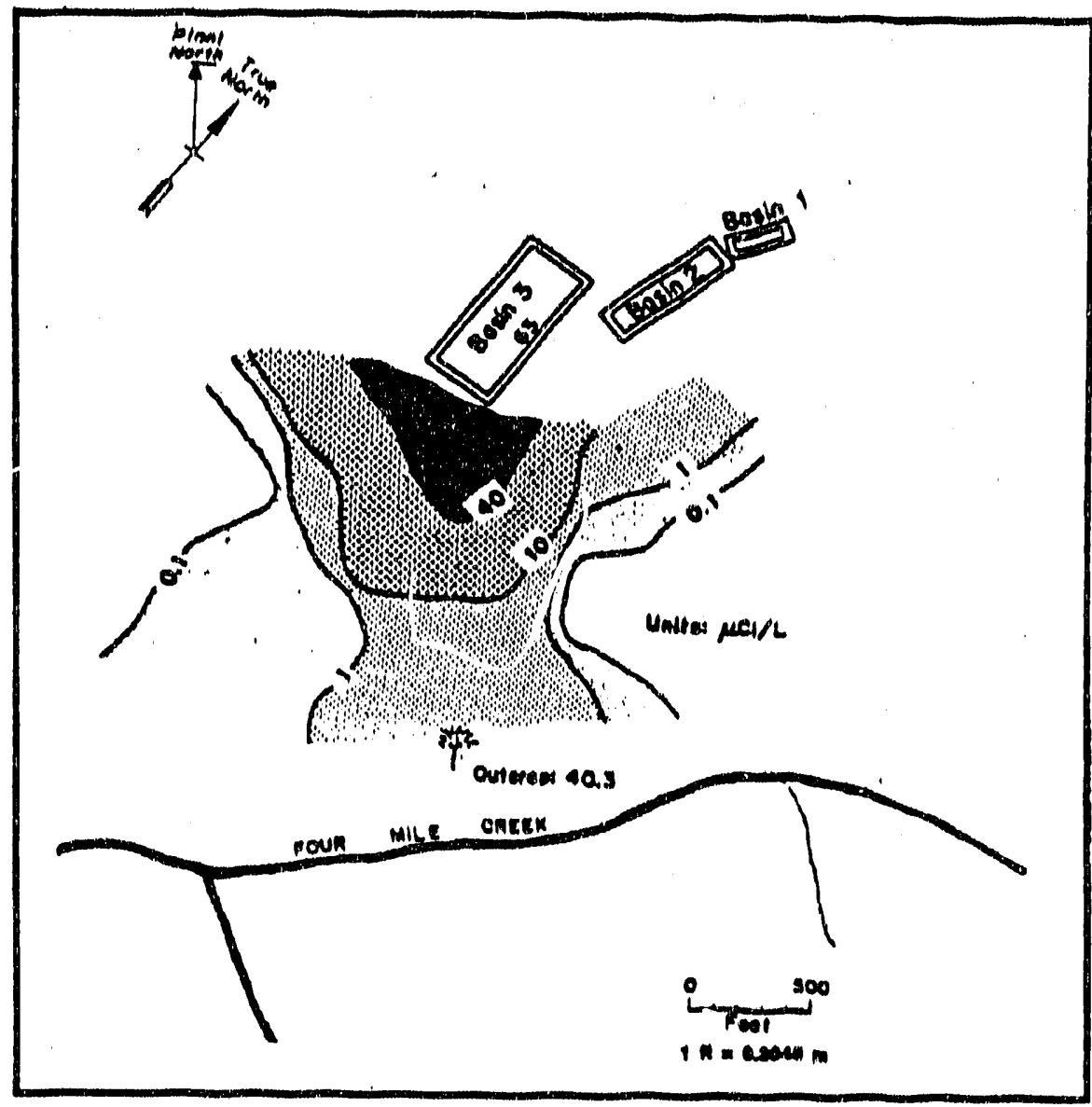

Figure 2.58. Horizontal Spread of Tritlum Plume Downgradient from the F-Area Seepage Basin 3

Table 2.8. Tritlum Activity in F-Area Seepage Basins Wells.

\begin{tabular}{lrrrrrrrr} 
Well & \multicolumn{7}{c}{ Annual Average (DCi/mL) } & \\
F-9 & 1982 & 1983 & 1984 & 1985 & 1986 & 1987 & 1988 \\
F-10 & 280 & 910 & 2,300 & 6,800 & & 4,830 & \\
F-10 & & & $-36,000$ & 39,000 & 44,000 & 60,500 & 32,500 \\
F-14 & 16,000 & 15,000 & 27,000 & 41,000 & 12,000 & 6,430 & \\
F-15 & 1,900 & 940 & 3,200 & 1,300 & 6,400 & 1,730 & 3130 \\
F-16 & 13,000 & 12,000 & 23,000 & 32,000 & 26,000 & 7,160 & 6545 \\
F-17 & 220 & 390 & 61 & 730 & 2,000 & 1,260 & 2910 \\
F-18 & 33 & 32 & 48 & 5,100 & 42,000 & & \\
F-18A & - & - & - & - & - & & 7368 \\
F-19 & - & 130 & 36 & 190 & $-13,100$ & \\
F-23 & 3,200 & 64 & 260 & - & - & - & - \\
F-24 & 28 & 25 & 44 & 44 & 41 & 40 & 45 \\
F-25 & 1,700 & 1,100 & 140 & 79 & 37 & 42 & 67
\end{tabular}




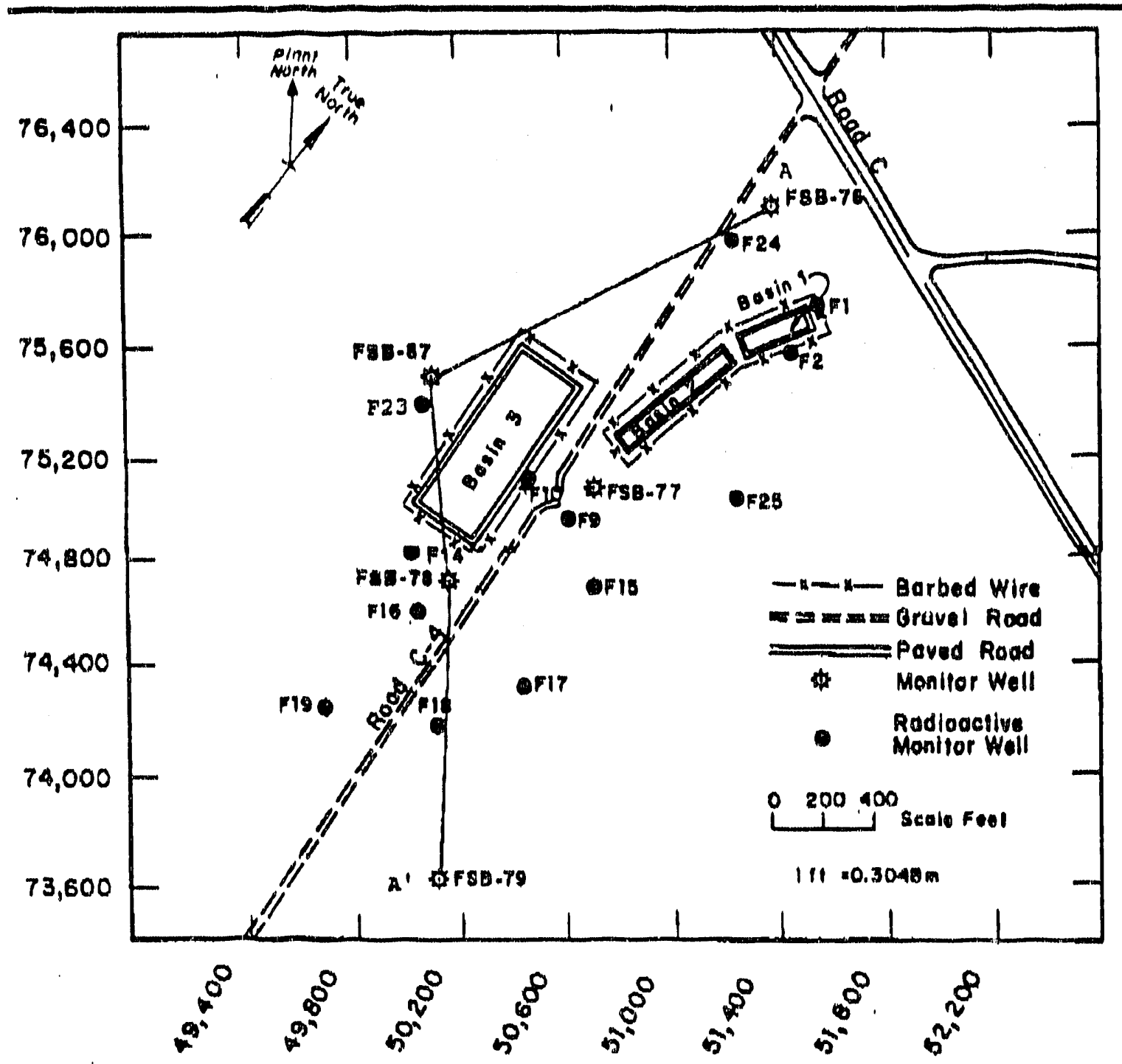

Figure 2.59. Placement of Wells Around the F-Area Seepage Basins

concentration increased from $74 \mathrm{pCl} / \mathrm{mL}$ in June 1963 to $6600 \mathrm{pCl} / \mathrm{mL}$ in July 1963 and continued to rise until it reached 18,600 $\mathrm{pCl} / \mathrm{mL}$ during November 1963 . No tritium was released to the basins between March 1957 and March 1959. If the increase represents tritlum releases that began in March 1959, the travel time of 52 months over a distance of $240 \mathrm{~m}$ results in $55 \mathrm{~m} / \mathrm{yr}$ velocity.

Tritlum was detected in Four Mile Creek, $490 \mathrm{~m}$ from Basin 3, in April 1967. If this tritlum is assumed to have left the basin during 1959, the flow velocity is $61 \mathrm{~m} / \mathrm{yr}$. The tritium measured in Four Mile Creek remained constant during 1968, 1969, and 1970 , increasing the likelihood that the detected tritium left the basin following the shutdown between 1957 and 1959. However, since tritlum had been released to the basin during 1955 when the basins were placed in operation, the vetected tritium may represent this plume. This approach would result in a flow rate of $41 \mathrm{~m} / \mathrm{y}$, which is more in line with the results of callbrated flow modeling that suggests a flo'n rate of about $20 \mathrm{~m} / \mathrm{yr}$.

Modeling the transport of tritium by 
groundwater from the F-Area seepage basins to the surface streams and then the Savannah River results in a predloted peak tritlum concentration of $0.081 \mathrm{pCl} / \mathrm{mL}$ at the time of basin closure.

\section{H-Area Seepage Basins}

The H-Area seepage basins are located in the center of SRS, southwest of Road $A$ and north of Road 4 (Figure 2.60), approximately $10 \mathrm{~km}$ from the nearest plant boundary. Basin 3 has been inactive since 1962. Basins 1, 2, and 4 became inactive in
December 1988. The four basins had a combined floor area of approximately 42,700 $\mathrm{m}^{2}$. The three basins that operated until 1988 had a combined capacity of approximately $140,000 \mathrm{~m}^{3}$ at overflow conditions. Wastowater to these basins entered through a single underground plpeline into Basin 1 , then traveled from Basin 1 through four pipelines into Basin 2 and then to Basin 4. The purpose of these basins was to use the soll column and groundwater pathways to delay the release of tritlum to surface streams.

Since 1955, the H-Area seepage basins

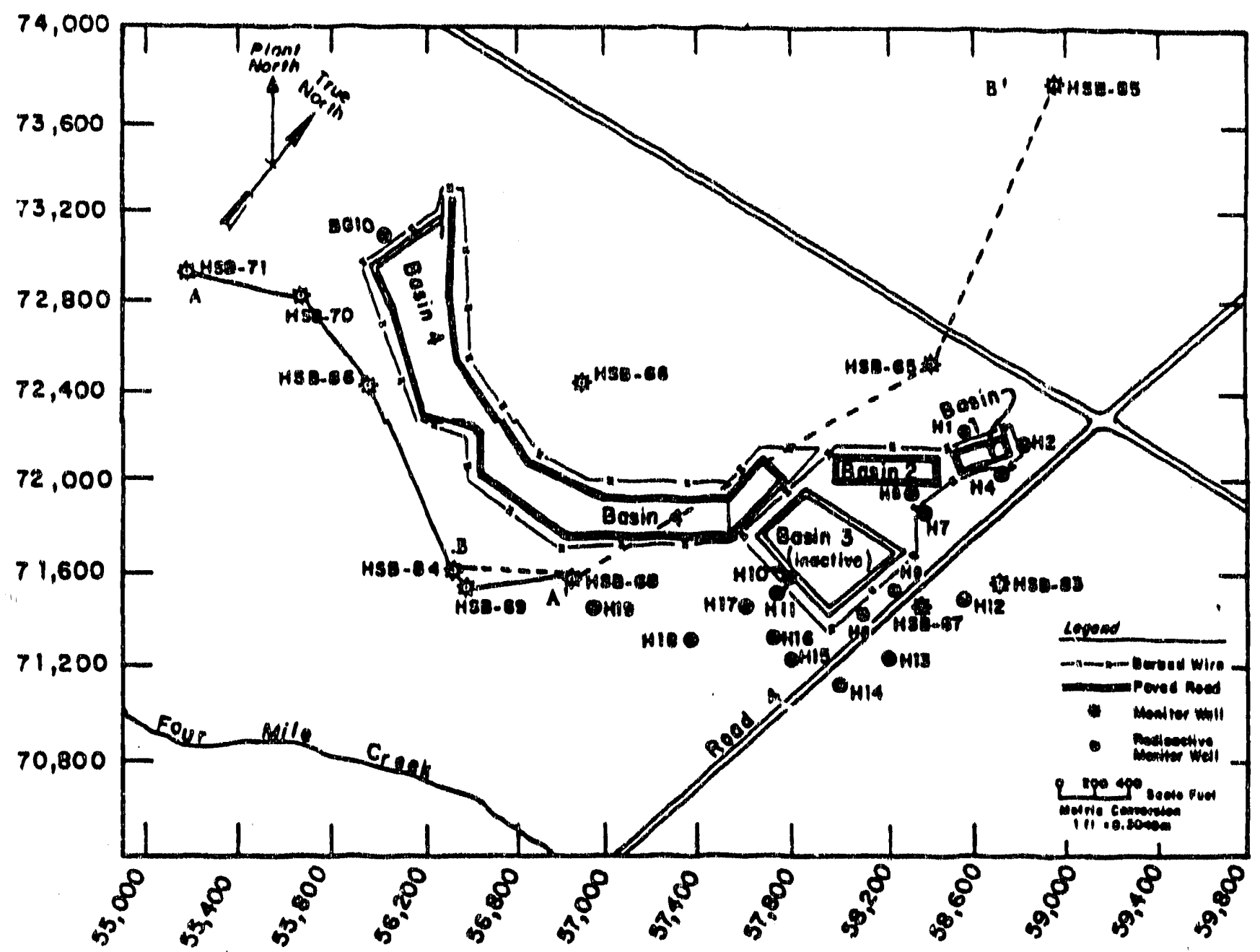

Figure 2.60. Locations of ri-Area Seepage Basin Wells 
have recelved wastewater containing cooling water from the tritlum faollties, other $\mathrm{H}$-Area operations, reteiltion basin transters, the receiving basins for offsite fuel, and two tank farm waste evaporators. The average dally flow into the basins for 1985 was $577 \mathrm{~m}^{3} /$ day. Radioactive releases to the seepage basins, as monitored by the Environmental Monitoring Sectlon, are greater than $99 \%$ tritium. First measurements were made in 1955 and the cumulatlve original release was approximately $330,000 \mathrm{Cl}$ through 1988 . The decaycorrected release is $150,000 \mathrm{Cl}$.

Flow out of the seepage basins is approximately vertically downward through the unsaturated zone to the water table. This vertical flow through the unsaturated zone resulted in a groundwaier mound beneath Basin 4. The horizontal component of groundwater flow from beneath the H-Area seepage basins is toward Four Mile Creok or the $\mathrm{H}$-Area effluent stream, a tributary to Four Mile Creek. The gradlent between Basin 4 and Four Mile Creek ranges between 0.02 and $0.033 \mathrm{~m} / \mathrm{m}$, but this rate includes an increased gradlent as the creek is approached. The gradient toward Four Mile Creek in the immediate vicinity of the basins themselves is approximately 0.010 to $0.018 \mathrm{~m} / \mathrm{m}$.

The water table at $\mathrm{H}$-Area seepage basins is 4.6 to $7.6 \mathrm{~m}$ below ground level and crops out at Four Mile Creek from 122 to $427 \mathrm{~m}$ south of the basins.

Groundwater monitoring has been performed since the basins were placed in operation. The annual average tritium concentrations in the groundwater at the $\mathrm{H}$.

Table 2.9. Tritlum Activity in H-Area Seepage Basin Wells.

\begin{tabular}{lrrrrrrrr} 
& \multicolumn{8}{c}{ Annual Average (pCi/n.: } \\
Well & 1982 & 1983 & 1984 & 1985 & 1986 & 1987 & 1988 \\
H2 & 19,000 & 18,000 & 50,000 & 31,000 & 23,000 & 22,900 & \\
H4 & 4,400 & 1,400 & 46,000 & 30,000 & 18,000 & 14,900 & 61,900 \\
H6 & 41,000 & 33,000 & 28,000 & 47,000 & 48,000 & 27,500 & 38,900 \\
H7 & 120 & 94 & 120 & 450 & 1,100 & 176 & 1,112 \\
H8 & 3,900 & 5,000 & 5,100 & 4,900 & 6,800 & 5,470 & 4,483 \\
H9 & 3,000 & 3,400 & 4,900 & 5,700 & 6,300 & 5,070 & 3,865 \\
H10 & 4,100 & 3,400 & 3,000 & 3,000 & 2,600 & 2,170 & 1,873 \\
H11 & 330 & 120 & 96 & 180 & 190 & 510 & 3,475 \\
H12 & 1,000 & 4,900 & 9,100 & 2,300 & 1,300 & 475 & 319 \\
H13 & 560 & 170 & 510 & 1,000 & 2,900 & 835 & 3,590 \\
H14 & 1,000 & 640 & 760 & 3,500 & 5,100 & 2,270 & 4,975 \\
H15 & 55 & 67 & 65 & 64 & 58 & 56 & 75 \\
H16 & 59 & 74 & 63 & 140 & 110 & 66 & 58 \\
H17 & 75 & 75 & 62 & 60 & 66 & 76 & 72 \\
H18 & 62 & 62 & 120 & 60 & & & \\
H18A & & & & & 33 & 54 & 64 \\
H19 & 5,300 & 790 & 360 & 1,500 & & 1050 & 1,170 \\
BG 10 & - & - & - & 38,000 & 21,000 & &
\end{tabular}


Area seepage basins from 1982 to 1988 are shown in Table 2.9. The locations of the wells sampled are shown in Figure 2.60. Investigations using monitoring wells have defined plumes of tritium emanating from the H-Area seepage basins in the water table. These plumes are in the form of fingers moving from the basins toward Four Mile Creek, as shown in Figure 2.61. Aquitards below the basins delay, but do not prevent, the vertical movement of groundwater. Tritium has been found in wells HSB 68A and 84B downgradient from the seepage basins. This tritium is beneath the aquitards in the Congaree Formation. Tritium that enters the Congaree will discharge to Upper Three Runs Creek; however, the travel time is about three times the rate to Four Mile Creek. The aquitard below the Congaree prevents vertical movement, and the hydraulic conductivity of the Congaree is such that the predominant flow direction is horizontal toward Upper Three Runs Creek.

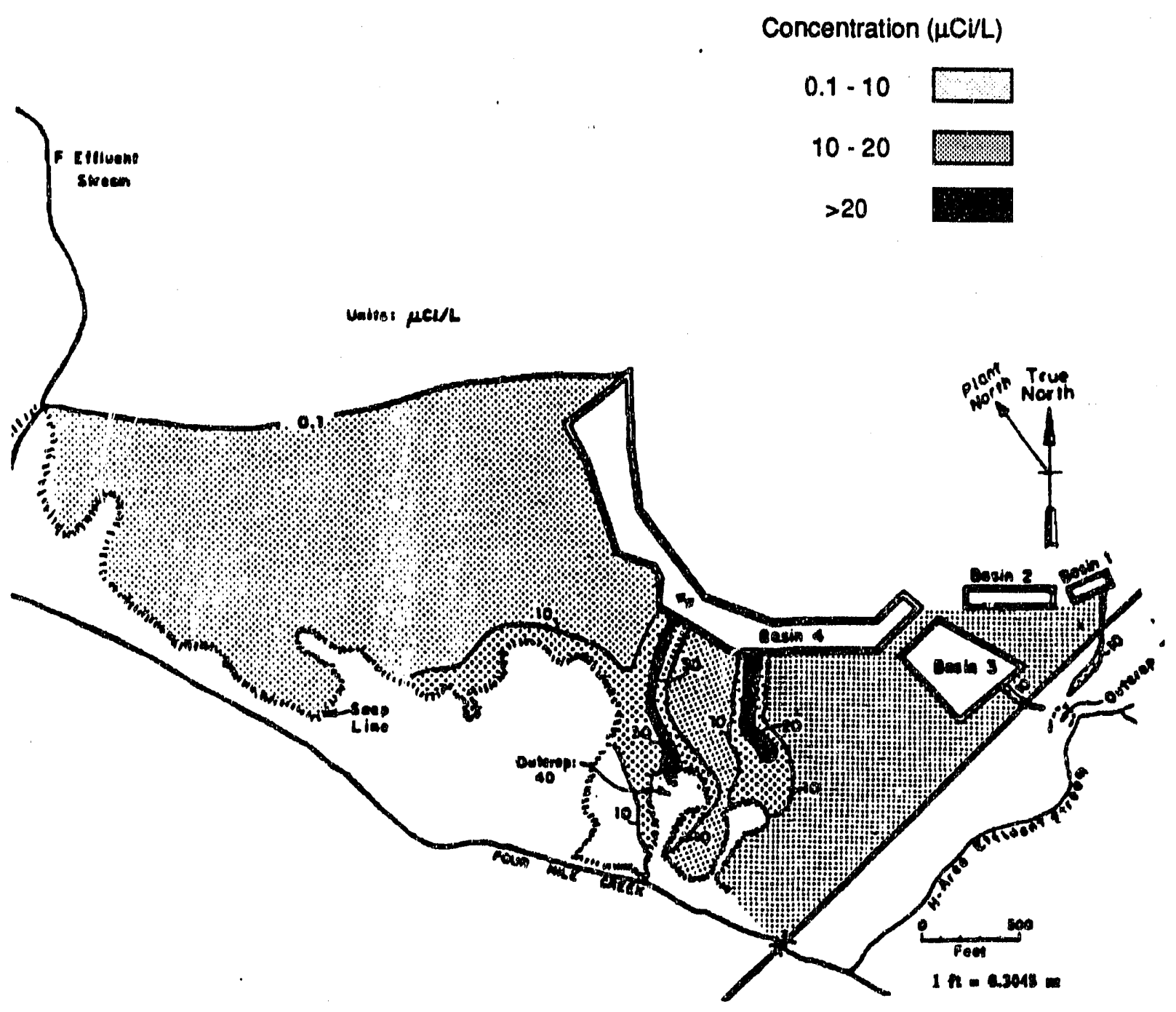

Figure 2.61. Tritium Plumes from H-Area Seepage Basins 
unsaturated zone to the water table. Once in the water table, tritium moves horizontally to Four Mile Creek and vertically into lower aquifers where it moves to Four Mile Creek and Upper Three Runs Creek and ultimately to the Savannah River. Groundwater travel time from the seepage basins ranges from approximately $14 \mathrm{yr}$ to greater than $50 \mathrm{yr}$, depending upon the exact pathway followed. Modeling the groundwater transport of tritium to the suiface streams and then to the Savannah Fiver results in a predicted peak tritium concesntration of $0.015 \mathrm{pCi} / \mathrm{mL}$ in the river at the time of basin closure.

\section{Tritium in the Burial Ground}

The radioactive waste burial grounds are solid radioactive waste storage sites centrally located at SRS. They are used to store all radioactive solid waste processed at the site, as well as periodic shipments from other DOE facilities. Tritium is one of the primary radionuclides contained in the solid waste stored at the burial grounds. Between 1952 and 1985 , an estimated $2400 \mathrm{~m}^{3}$ of tritiumcontaminated solid radioactive waste was stored. Unlike most other radionuclides, tritium is rapidly leached and moves freely with flowing groundwater. Tritium plumes exist in the groundwater beneath the burial grounds and extend to the south toward Four Mile Creek (Figures 2.62 and 2.63).

Tritium concentrations averaged over all grid monitoring wells in the 643-G burial ground for the years 1974-1984 are listed in Table 2.10, along with estimates of the total amount
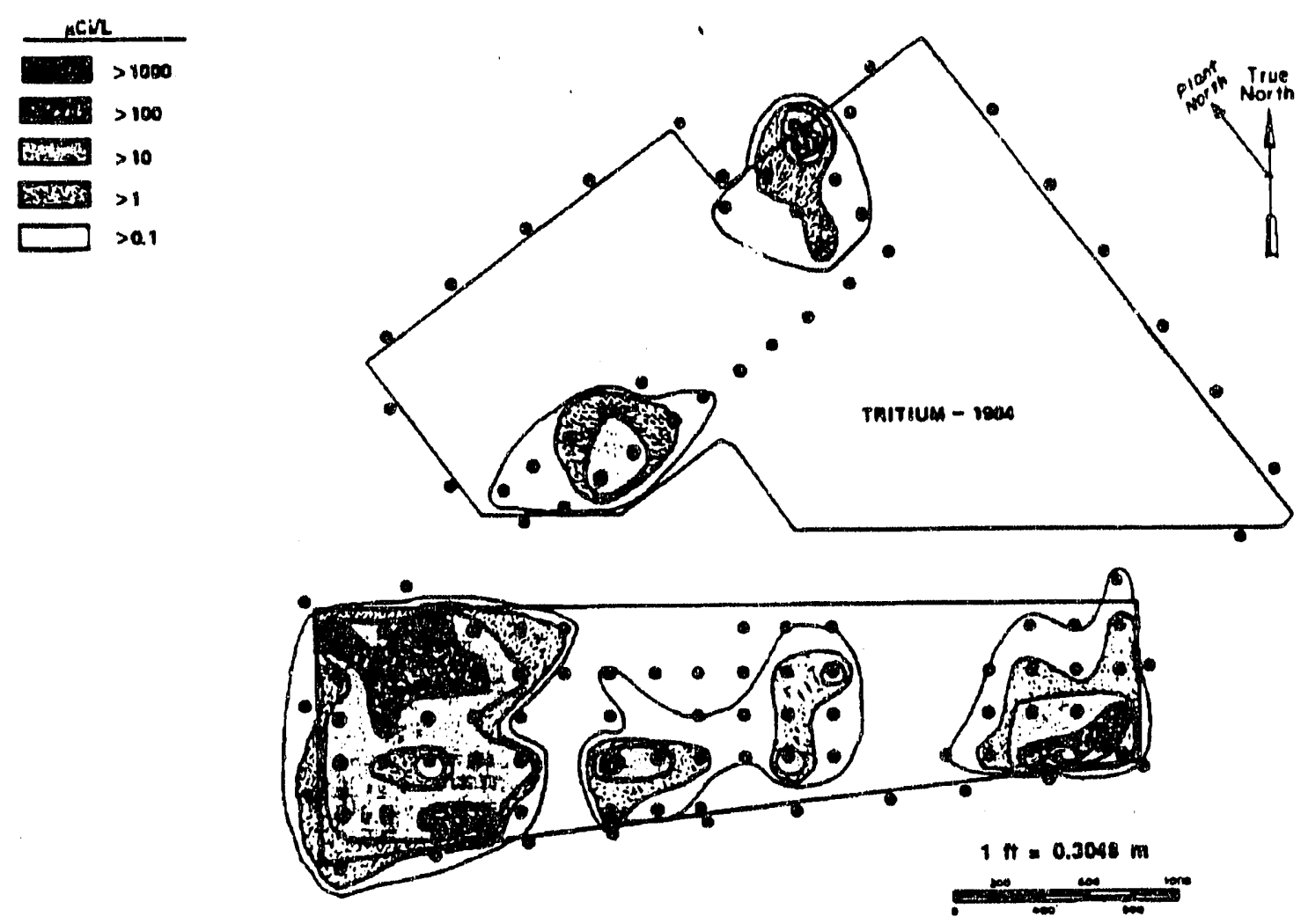

Figure 2.62. Tritium Zones in Groundwater at the Burial Ground 


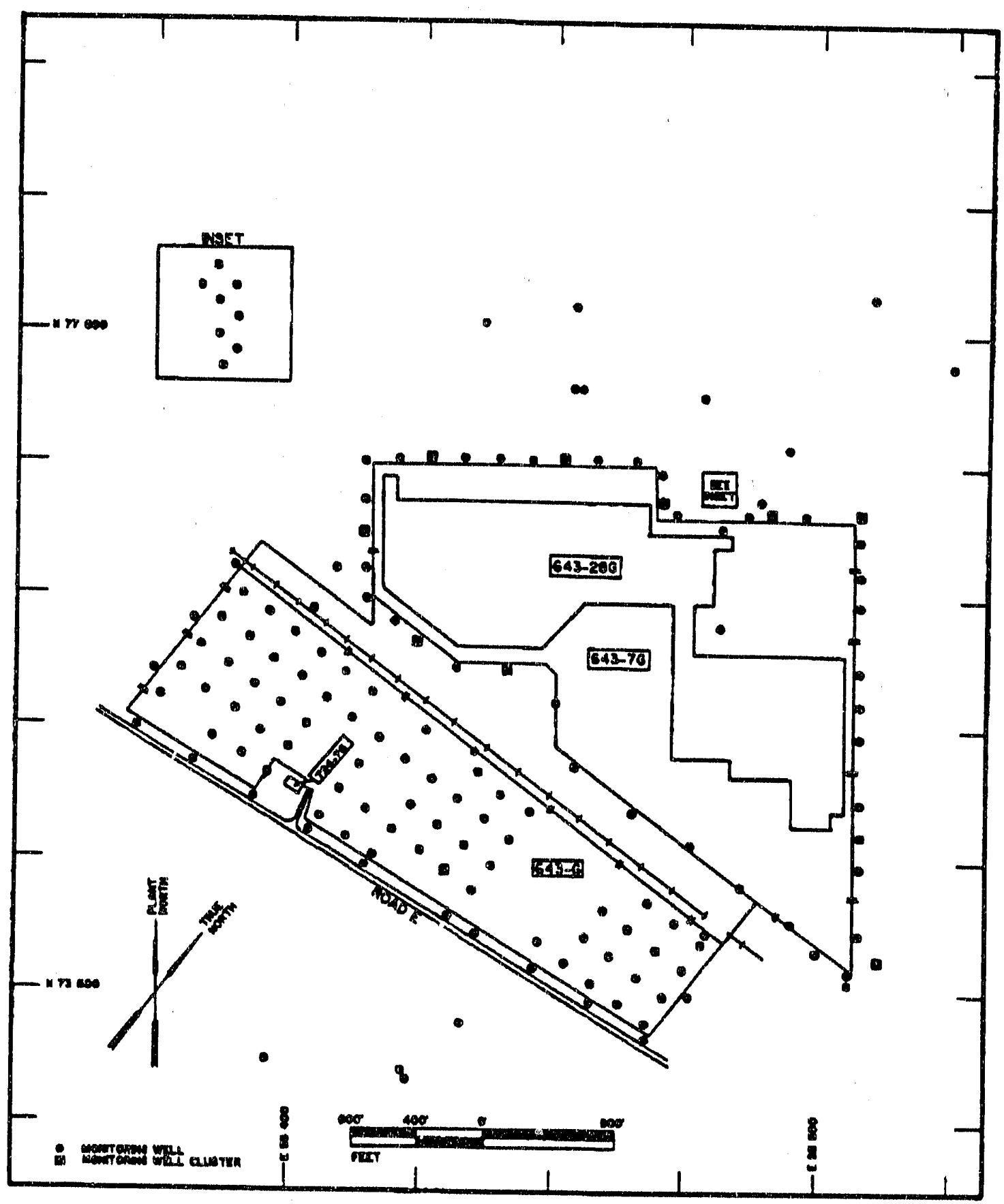

Figure 2.63. Srchematic of Grid Wells in the Low-Level Waste Burial Ground 
Table 2.10. Estimates of Tritium in Groundwater Beneath 643-G.

\begin{tabular}{ccc} 
Year & $\begin{array}{c}\text { Average } \\
\text { Concentration } \\
\text { (uCilh) }\end{array}$ & $\begin{array}{c}\text { Tritium in } \\
643-\text { G Plume } \\
\text { (Ci) }\end{array}$ \\
\hline & & \\
1974 & 31.6 & 13,300 \\
1975 & 59.8 & 25,200 \\
1976 & 58.0 & 24,400 \\
1977 & 59.9 & 24,800 \\
1978 & 90.4 & 38,100 \\
1979 & 65.8 & 27,700 \\
1980 & 91.6 & 38,600 \\
1981 & 88.8 & 37,400 \\
1982 & 57.7 & 24,300 \\
1983 & 34.7 & 14,600 \\
1984 & 87.5 & 36,800 \\
& &
\end{tabular}

of tritium in the groundwater. Tritium concentrations obtained from the grid monitoring wells in the 643-7G and 643-28G burial grounds have increased steadily since 1981 .

Estimates of the total amount of tritium in the groundwater beneath portions of the 643$7 \mathrm{G}$ and $643-28 \mathrm{G}$ burial grounds are shown in Table 2.11. For 1984, the estimate was 5600 $\mathrm{Ci}$ of tritium. In addition, substantial amounts of tritium are suspected in groundwater beneath portions of the buria! grounds not monitored by grid wells (see Figure 2.63). Most of these areas are not yet amenable to well installation because of active burial operations. As an indication of the amounts of tritium in the eastern side of the 643-7G and 643-28 a burial grounds, a special study in 1983 of a $2028-\mathrm{m}^{2}$ site in that area showed approximately $2000 \mathrm{Ci}$ of tritium in the groundwater.

The burial ground is located in an interstream area between two tributaries of the Savannah River: Upper Three Runs Creek to the nortli and Four Mile Creek to the south. The sediments below the burial ground are saturated with groundwater, beginning at a depth of approximately $12 \mathrm{~m}$. Part of this groundwater flows to Four Mile Creek and part to Upper Three Runs Creek. Measurements in cluster wells show that the pressure in sediments in the Congaree Formation is lower than the pressure above and below. Thus, water flows to the Congaree Formation from both above and below, limiting the depth of circulation of water from the burial ground. Of particular geohydrologic significance are the confining beds, which retard the vertical movement of the groundwater beneath the Burial Ground.

The difference in elevation between Upper Three Runs Creek and Four Mile Creek influences the flow of groundwater. The bed of Upper Three Runs Creek has eroded approximately $16.8 \mathrm{~m}$ deeper than that of Four Mile Creek near the burial ground area, and the difference in stream bed elevation has displaced the water table divide about $300 \mathrm{~m}$ toward Upper Three Runs Creek. The water table gradient from the southern edge of the 643-G Burial Ground to Four Mile Creek is $0.01 \mathrm{~m} / \mathrm{m}$; the gradient from the northern

Table 2.11. Annual Average Concentrations of Tritium In $643-7 \mathrm{G}$ and 643-28G Grid Wells.

\section{Annual Average}

Concentration aci/mL

Total Tritiurn in Plume (CD)

$\begin{array}{rrr}1981 & 600 & 200 \\ 1982 & 2,800 & 900 \\ 1983 & 8,800 & 2,800 \\ 1984 & 18,000 & 5,600\end{array}$


boundary of the 643-7G Burial Ground to Upper Three Runs Creek is $0.02 \mathrm{~m} / \mathrm{m}$. The gradient in the Congaree Formation from the Burial Ground to Upper Three Runs Creek is approximately $0.003 \mathrm{~m} / \mathrm{m}$.

Although sediments in the Buriai Ground area are highly heterogenous, flow over a distance apparently tends to reduce the effects of this variability. Sixteen groundwatervelocity tritium tracertests have been made throughout the area over a period of several years. Simultaneously, water table gradients were observed. A least square linear regression analysis of the data shows a strong correlation between watertable gradient and groundwater velocity. The average velocity varies at the rate of $14.5 \mathrm{~m} / \mathrm{yr} / 4 \%$ gradient, with a correlation coefficient of 0.988 .

Water flowing through porous media, such as the sediments of the Burial Ground, exhibits a distribution of velocities in the small flow channels due to the heterogeneity of the media and to a friction gradient extending from the channel walls out to the center where friction is least. As a result, a tracer released into the system will assume a normal distribution in the longitudinal direction as flow proceeds. The leading edge of the distribution will precede the centroid by some multiple of the centroid depending on pore and grain characteristics.

Results of a flow experiment in the southwest corner of theBurial Ground are shown in Figure 2.64. Three tritium sources (residues of irradiated lithium-aluminum after the thermal extraction of the tritium ) were buried in 1957 and observed at intervals until 1970. The centroid was $76 \mathrm{~m}$ downgradient, but the leading edge had not arrived at detection wells $80 \mathrm{~m}$ beyond the centroid. The leading edge was moving not more than twice the average rate. The conservative estimate to apply to the leading edge is, therefore, twice the average rate.

Applying these rates to observed watertable gradients on flow paths originating in the east, middle, and southwest parts of the 643-G Burial Ground produces results shown in Figure 2.65. The figure shows the estimated time required for tritium released at the head of the flow path to move to the outcrop. The average velocities for three flow paths are $12 \mathrm{~m} / \mathrm{yr}, 18 \mathrm{~m} / \mathrm{yr}$, and $24 \mathrm{~m} / \mathrm{yr}$. These velocities are consistent with the detailed horizontal (and vertical velocities) that resulted from calibrated groundwater models.

In 1988 it was estimated that 4.2 million $\mathrm{Ci}$ of tritium had been interred in the Burial Ground since the beginning of SRS operations. After decay it is estimated that 1.5 million Ci remains which is leachable and could get to the groundwater. The geohydrologic information previously presented indicates that the water flow patterns in the vicinity of the burial ground are very complex. A groundwater divide occurs in this area, and water flows north to Upper Three Runs, south to Four Mile Creek, and vertically into the Congaree Formation. As a result, the groundwater crops out in the streams and then flows to the Savannah River. Modeled results indicate this peak flux of tritium will be $0.00671 \mathrm{pCi} / \mathrm{mL}$ entering the Savannah River in the Year 2085.

\section{Reactor Area Seepage Basins}

The reactor area seepage basins were constructed and operated, beginning in 1957 , to receive low-level radioactive wastewater from disassembly basin purges in $R, K, P, C$, and $L$ Areas. The basins were constructed on relatively high ground outside the area perimeter fences. The basins in $K$ and $R$ 


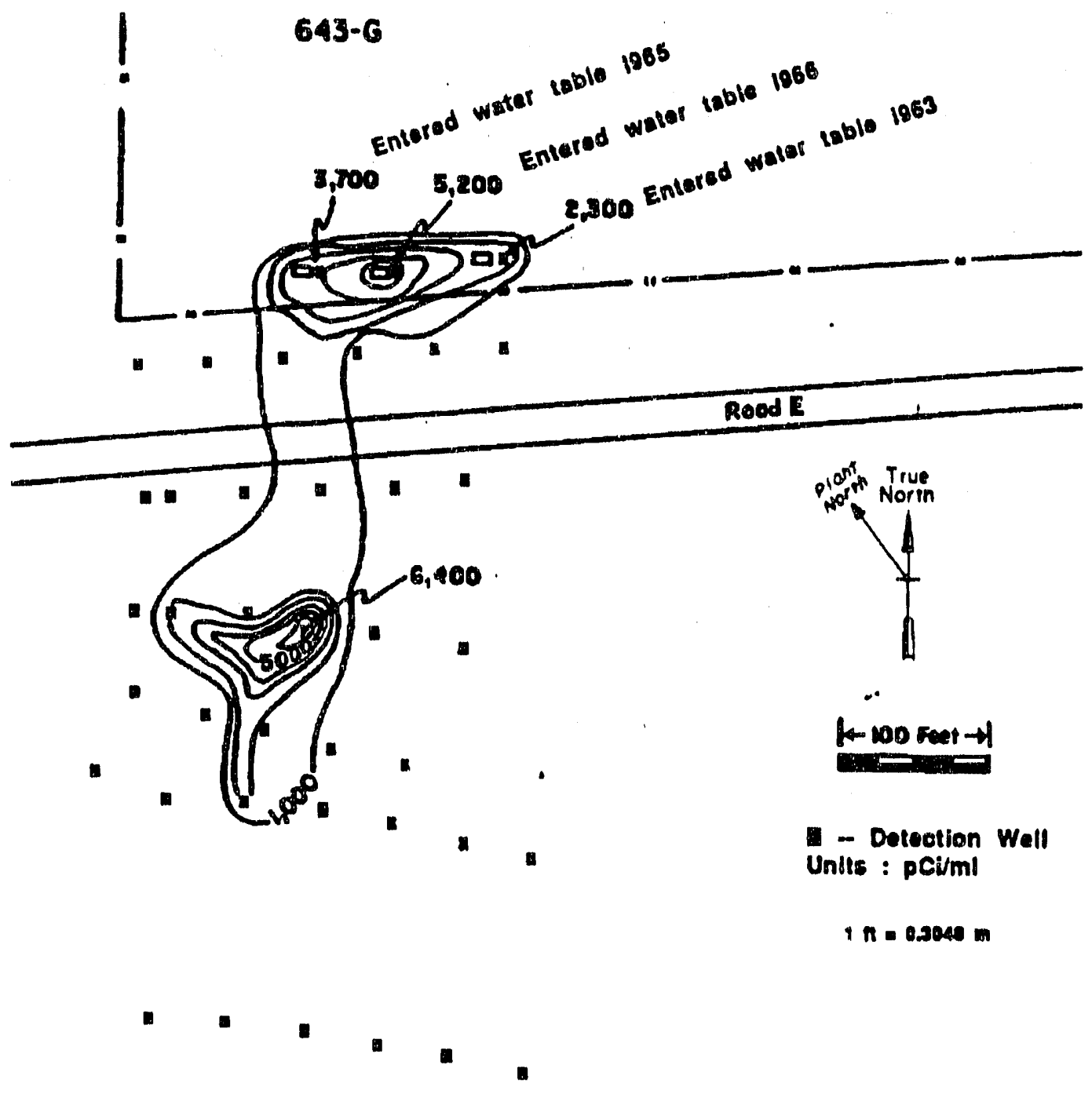

Figure 2.64. Tritium from Spent Melt Test in Groundwater in October 1970 


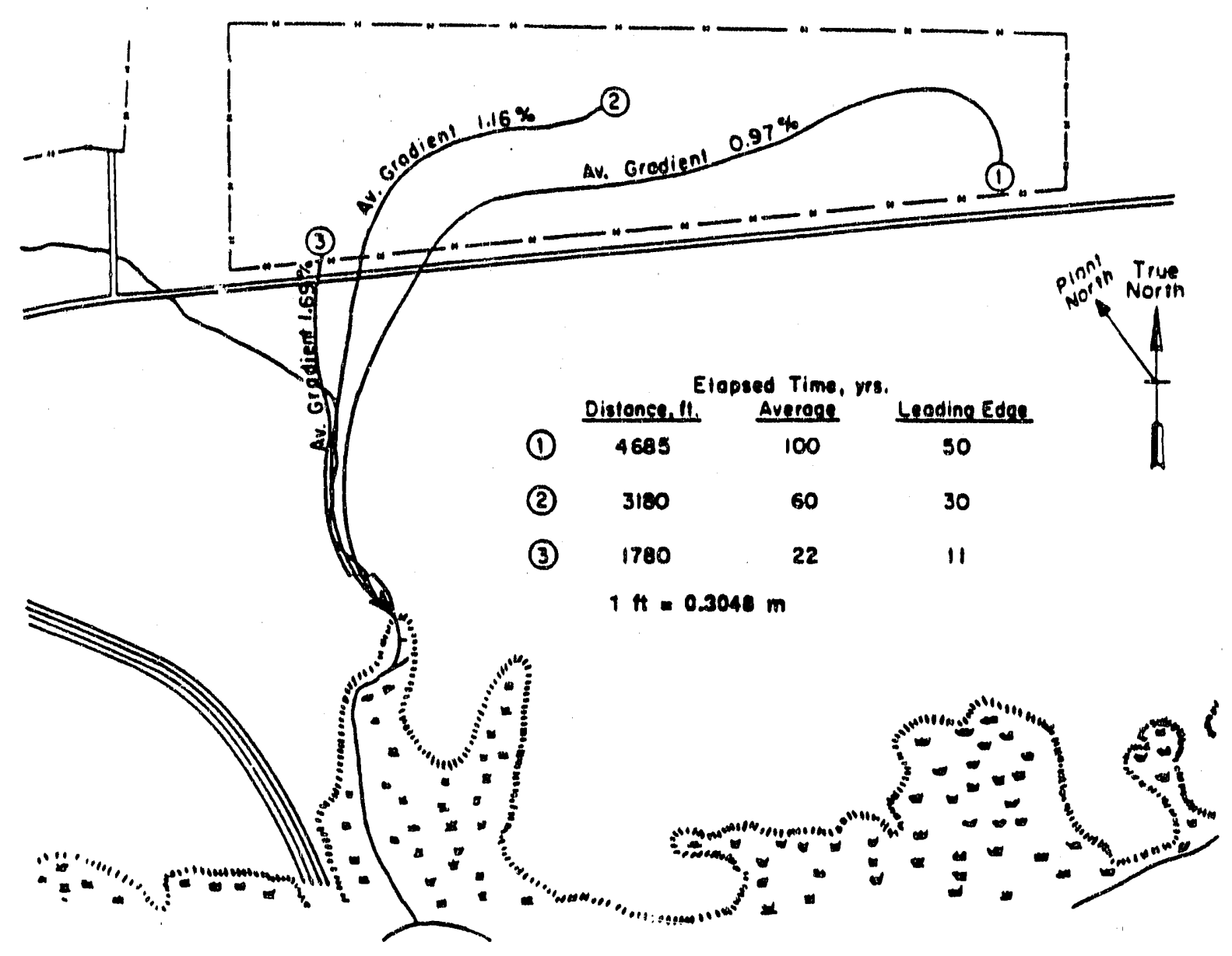

Figure 2.65. Time for Water and Tritium to Travel 643-G Burial Ground Flow Paths

Areas were last used in 1960 and 1964, respectively. The basin in $\mathrm{C}$ area was last used in 1986, while the basins in L Area were out of service between 1968 and 1985. From 1965 to the present the containment basin in $K$ Area was used for the disassembly basin purges. Figure 1.1 shows the location of the reactor areas at SRS.

\section{K-Area Seepage Basin}

The location of the K-Area Seepage Basin is shown in Figure 2.66. The K-Area Seepage Basin was used intermittently from 1959 until 1965 at which time it was removed from service. During the period of operation, ap- proximately $5200 \mathrm{Ci}$ of tritium were released to the basin. Most of the tritium is believed to have left the basin via the atmospheric or groundwater pathways. The basin is located on a very gentle slope leading to Indian Grave Branch, a tributary to Pen Branch Creek, 710 $m$ to the west of the basin. Monitoring wells were established around the seepage basin in 1984. The levels of tritium activity observed in these wells are relatively low, ranging from 40 to $730 \mathrm{pCi} / \mathrm{mL}$ (Table 2.12).

It is assumed that the tritium which seeped from the basin to the groundwater moved to Indian Grave Branch, where it discharged to the stream. This is calculated to have resulted 


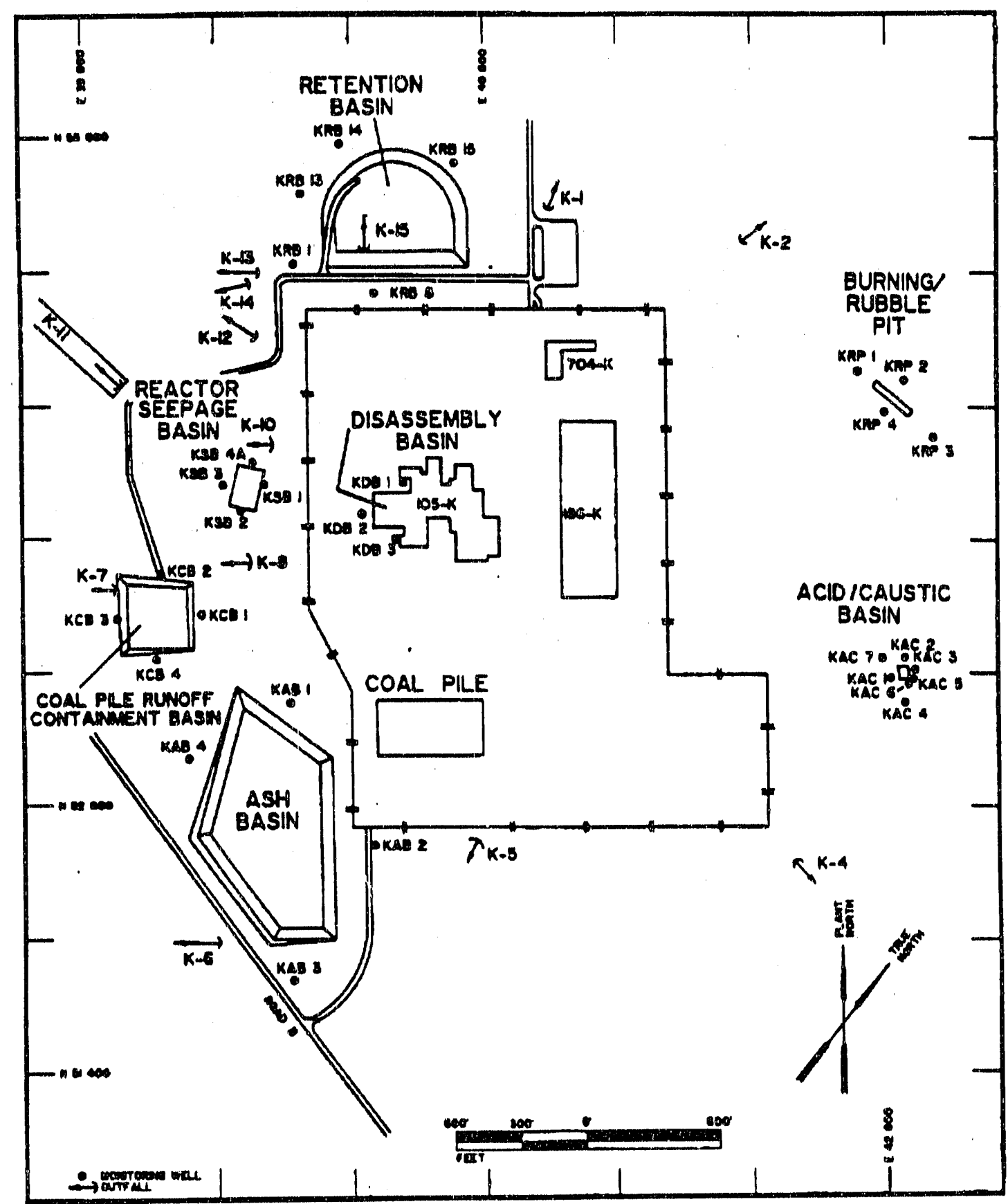

Figure 2.66. K-Area Showing Locations of the Reactor Seepage and Containment Basins and the Monitoring Wells Around Each Basin

Table 2.12. Tritium Concentrations in K-Area Seepage Basin Monitoring Wells (pCi/mL).

$\begin{array}{ccccc}\text { Well } & & & \\ \text { Number } & \frac{1985}{1} & \frac{1986}{280} & \frac{1987}{730} & \frac{1988}{232} \\ 2 & 56 & 55 & 42 & 39\end{array}$


Table 2.13 Tritium Concentrations in K-Area Containment Basin Monitoring Wells (pCl/mL).

\begin{tabular}{rrrrrrrrr}
$\begin{array}{c}\text { Well } \\
\text { Number }\end{array}$ & $\frac{1982}{930}$ & $\frac{1983}{180}$ & $\frac{1984}{81}$ & $\frac{1985}{64}$ & $\frac{1986}{160}$ & $\frac{1987}{211}$ & $\frac{1988}{194}$ \\
\hline 1 & 31000 & 25000 & 330000 & 73000 & 230000 & 223000 & 58075 \\
8 & 31000 & 49000 & 69000 & 25000 & 31000 & 10900 & 13513 \\
13 & 70000 & 4900 & 1000 & 14600 & 34425 \\
14 & 68000 & 25000 & 29000 & 14000 & 19000 & 1400 & 95175
\end{tabular}

in a peak concentration of $0.00014 \mathrm{pCl} / \mathrm{mL}$ of tritium in the Savannah River.

\section{K-Area Containment Basin}

The K-Area containment basin has been used since 1965 for the disposal of purge water from the K-Area disassembly basin. The basin, a $190,000 \mathrm{~m}^{3}$ capacity facility, is about $12 \mathrm{~m}$ above the water table. From 1963 through 1982, a total of $190,000 \mathrm{Cl}$ of tritium were released to the basin. Two monitoring wells were installed in 1963 when the basin was constructed, and three additional monitoring wells were drilled and placed in service in 1966. The locations of the monitoring wells are shown in Figure 2.66. Monitoring results for the years 1982-1988 are given in Table 2.13.

Because of the soil characteristics of the containment basin, water moved into the ground at a high rate. Once the tritium left the containment basin it migrated through the unsaturated zone to the water table approximately $12 \mathrm{~m}$ below the ground surface. Once it reached the water table, it moved in a westward direction to Indian Grave Branch where about $10,000 \mathrm{Cl} / \mathrm{yr}$ outcrops to the stream. Recent modeling studies have indicated that the source leaks through the aquitard and enters Aquifer 2 (the old

Congaree) and continues to migrate westward toward the Savannah River. This flow path covers a great distance and therefore little tritium will reach the river by this pathway.

\section{L-Area Oll and Chemical Basìn}

The L-Area oil and chemical basin is located near the L-Area seepage basin (Figure 2.68). It has a volume of approximately 2300 $\mathrm{m}^{3}$. This basin was put into operation in 1961 and received wastewater trom all areas of the site, but primarily from the reactur areas. It became inactive in 1979. The amount of tritium released to the basin was estimated in 1985 to be $35,000 \mathrm{Ci}$ (Du Pont 1986). Monitoring wells were installed around the perimeter of the L-Area oil and chemical basin, and these wells have been sampled quarterly since 1982. Table $2.14 \mathrm{gives}$ the results of the

Table 2.14.L-Area Moriitoring Well Average Tritium Concentrations for $1988(\mathrm{pCl} / \mathrm{mL})$.

\begin{tabular}{ccc}
$\begin{array}{c}\text { Well } \\
\text { Number }\end{array}$ & $\begin{array}{c}\text { Oil Chemical } \\
\text { Chemical }\end{array}$ & $\begin{array}{c}\text { Seepage } \\
\text { Basin }\end{array}$ \\
\hline & & \\
1 & 769 & 1617 \\
2 & 4 & 4 \\
3 & 5 & 16 \\
4 & 77 & 2325
\end{tabular}




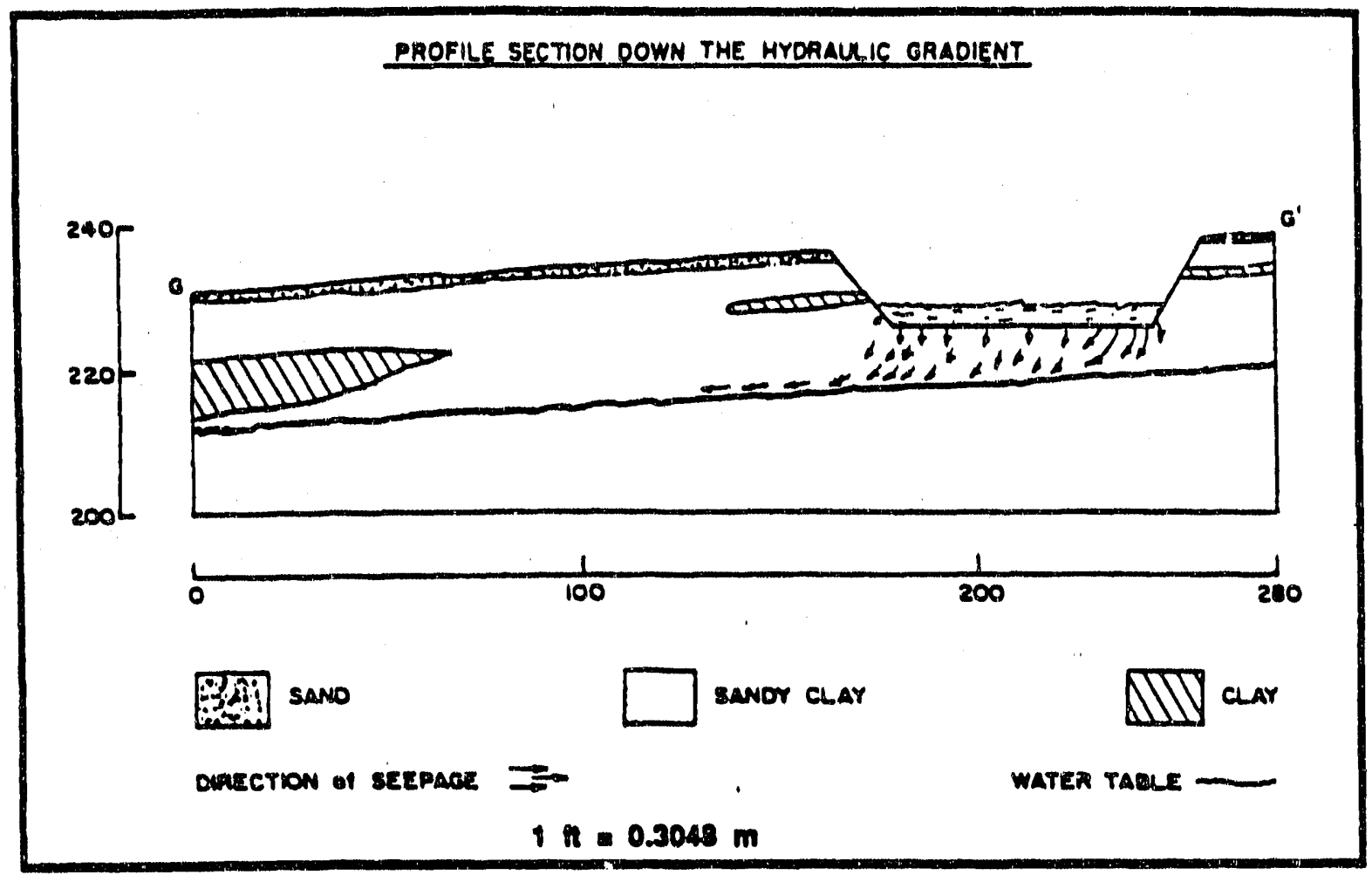

Figure 2.67. Cross Section of the L-Area Oil and Chemical Basin Based on Preconstruction Data

monitoring for tritium in these wells. Figure 2.67 shows a cross section of the basin and the flow path of water from the basin to the shallow water table. Flow from the basin was to Steel Creek while the basin was active. The present flow is to $L$ Lake. The groundwater discharges to Steel Creek or L l.ake.

\section{L-Area Seepage Basin}

The reactor in L Area operated from 1955 until 1968, when it was placad on standby. During this period, purge water was released to the L-Area seepage basin in 1958-1959, 1961-1965, and 1967 to 1969 . The reactor was restarted in 1985, and since that time fuel storage basin purges have again been sent to the seepage basin. The location of the L.-Area seepage basin is shown in Figure 2.68.
The water table at the seepage basin is rather shallow, about $6.2 \mathrm{~m}$ below the ground surface. The basin was about $760 \mathrm{~m}$ from Steel Creek prior to construction of $L$ Lake, and currently it is about 458 meters from $L$ Lake. From 1955 through 1985, about 7800 $\mathrm{Ci}$ of tritium were released to the L-Area seepage basin (Du Pont 1986).

Following the release to the L-Area seepage basin, water moved generally vertically downward through the unsaturated zcrie to the water table. Once the saturated zone was reached, the water traveled principally in a horizontal flow path to Steel Creek (later L Lake) due to the existing gradient (about $0.02 \mathrm{~m} / \mathrm{m}$ ). Therefore, all the tritium leaving the L-Area basin discharged to Steel Creek or L Lake. The basin has been 


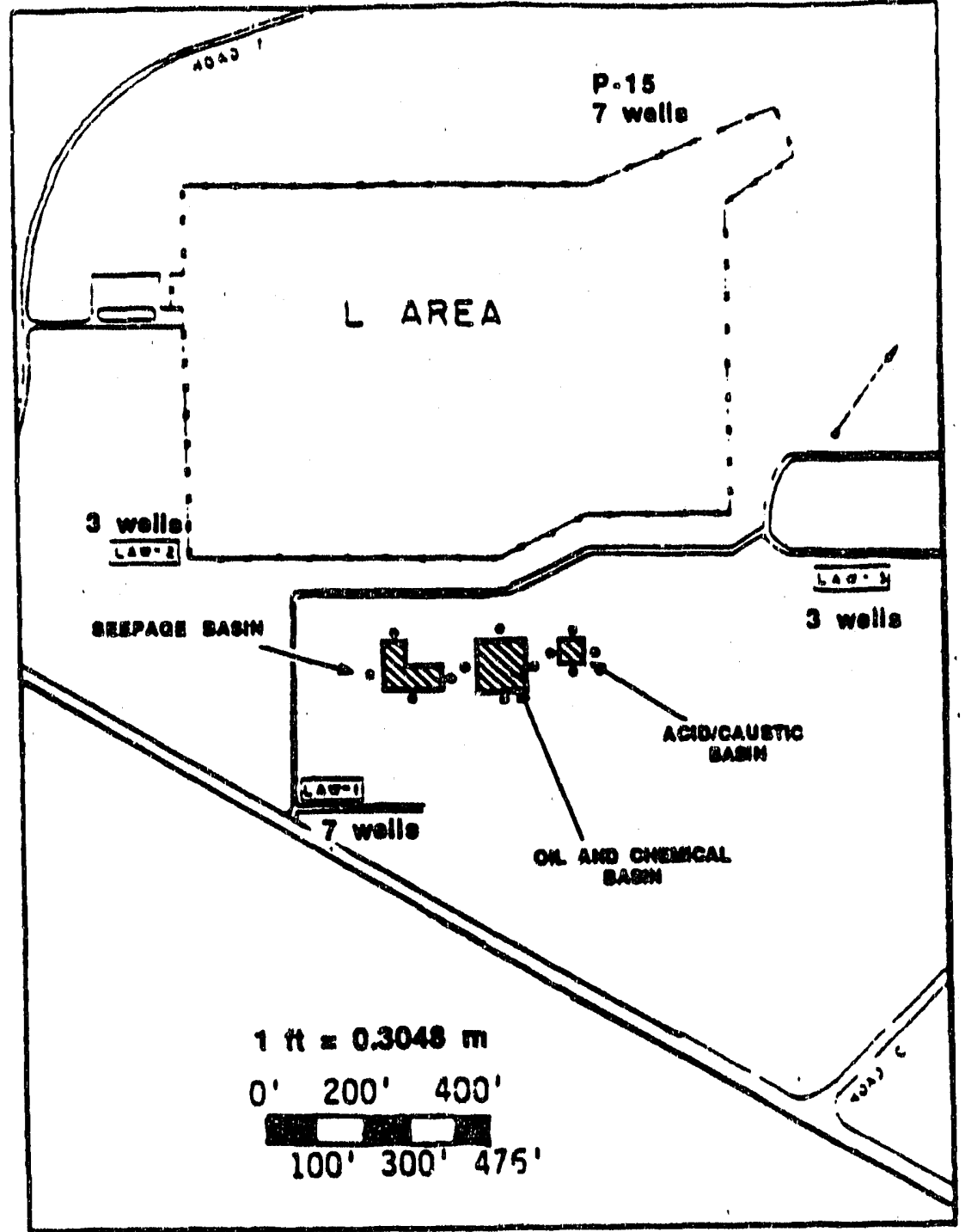

Figure 2.68. L-Area Showing the Locations of the Reactor Seepage and Oll and Chemical Basins with the Monitoring Wells at Each Basin

monitored by four wells of the LSB series (Figure 2.68). Table 2.14 gives the results of monitoring for tritium in those wells.

\section{C-Area Seepage Basins}

The C-Area se日page basins are located near the center of the site. These seepage basins received discharge purge waters from 1959 to 1970 , and from 1978 to 1985 . (C Reactor last operated in 1985.) The basins are connected in series, with water entering
Basin 1 then moving through to Basins 2 and 3. Through 1985, approximately 56,000 $\mathrm{Ci}$ of tritium were discharged to the seepage basins (Du Pont 1986).

Monitoring wells were placed around the C-Area seepage basins in the1960s and monitored regularly for tritium. The annual average concentration of tritium in the wells for $1982-1988$ are given in Table 2.15. The locations of these monitoring wells are shown in Figure 2..69. 


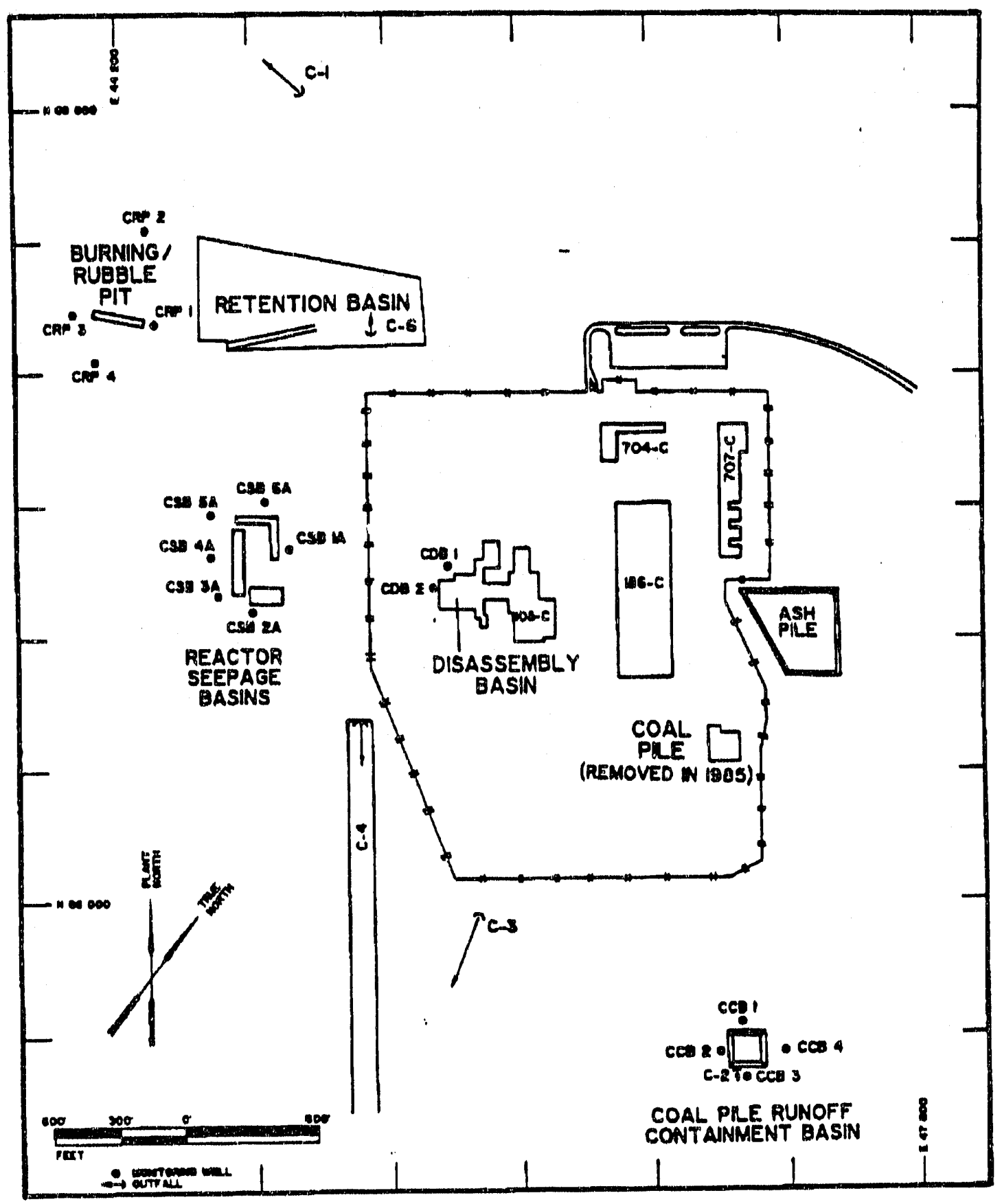

Figure 2.69. C-Area Showing the Location of the Reactor Seepage Basins and the Associated Monitoring Wells 
Table 2.15. Tritlum Concentrations in C-Area Seepage Basin Wells (pCl/mL).

\begin{tabular}{cccccccc} 
Well & & & & & & \\
Number & 1982 & 1983 & 1984 & 1985 & 1986 & 1987 & 1988 \\
\hline $1 A$ & 14 & 43 & 52 & 29 & 30 & 61 & 42 \\
\hline $2 A$ & 38 & 35 & 350 & 70 & 64 & 70 & 80 \\
3 & 1600 & 1900 & 58000 & 110000 & 82000 & 67000 & 35850 \\
$4 A$ & 88 & 63 & 74000 & 84000 & 70000 & 55300 & 38500 \\
$5 A$ & 360 & 180 & 13000 & 11000 & 8000 & 6440 & 4973 \\
$6 A$ & 13000 & 160000 & 46000 & 4100 & 6100 & 2230 & 1852 \\
\hline
\end{tabular}

The infiltrating water from the seepage basins moves vertically through the unsaturated zone to the water table. Upon reaching the water table it moves in a path with both vertical and horizontal components generally southwestward toward Four Mile Creek.

\section{P-Area Seepage Basins}

$P$ Area, which is located in the south central portion of SRS, discharges its purge water to three seepage basins southwest of the reactor (Figure 2.70). Lower Three Runs Creek to the east, Steel Creek to the southwest, and Meyers Branch to the south and east create a groundwater island in $P$ Area. Through 1985 a total of $64,000 \mathrm{Ci}$ of tritium had been released to the P-Area seepage basins (Du Pont 1986). Groundwater monitoring began around the basins early, and seven wells of the PSB series are now used to monitor for tritium. The locations of these monitoring wells are shown in Figure 2.70. Results of the monitoring program are presented in Table 2.16.

The hydraulic gradient in the water table varies across $P$. Area and increases near the surface streams. From the seepage basins, water moves generally vertically downward in the unsaturated zone ( $a$ depth of about $9 \mathrm{~m}$ ).

Once in the saturated zone, flow occurs in both a horizontal and vertical direction toward the west and Steel Creek. Recent modeling indicates that approximately $10 \%$ of the volume of tritium leaving the seepage basins discharges to Steel Creek from the water table. The remaining $90 \%$ moves across the aquitard into Aquifer 2 and moves in a southwesterly direction toward the Savannah River.

\section{Other Seepage Basins}

Small amounts of tritium ( 243 and $470 \mathrm{Ci}$, respectively) were released to the $S R L$ and Ford Building seepage basins. By 1988, this tritium had decayed to an inventory of 65 and $126 \mathrm{Ci}$. There is no indication that any of the tritium has migrated to a surface outiorop or that a significant amount will reach an outcrop before decaying.

\section{TRITIUM TRANSPORT FROM SRS TO THE ENVIRONMENT}

In Chapter 1 of this report, it was shown that tritium is released from SRS facilities into the local environment in one of three forms, tritiated hydrogen, tritiated water vapor, or liquid tritiated water. Tritiated hydrogen and tritiated water vapor are released to the atmosphere. Liquid tritiated watei is released 


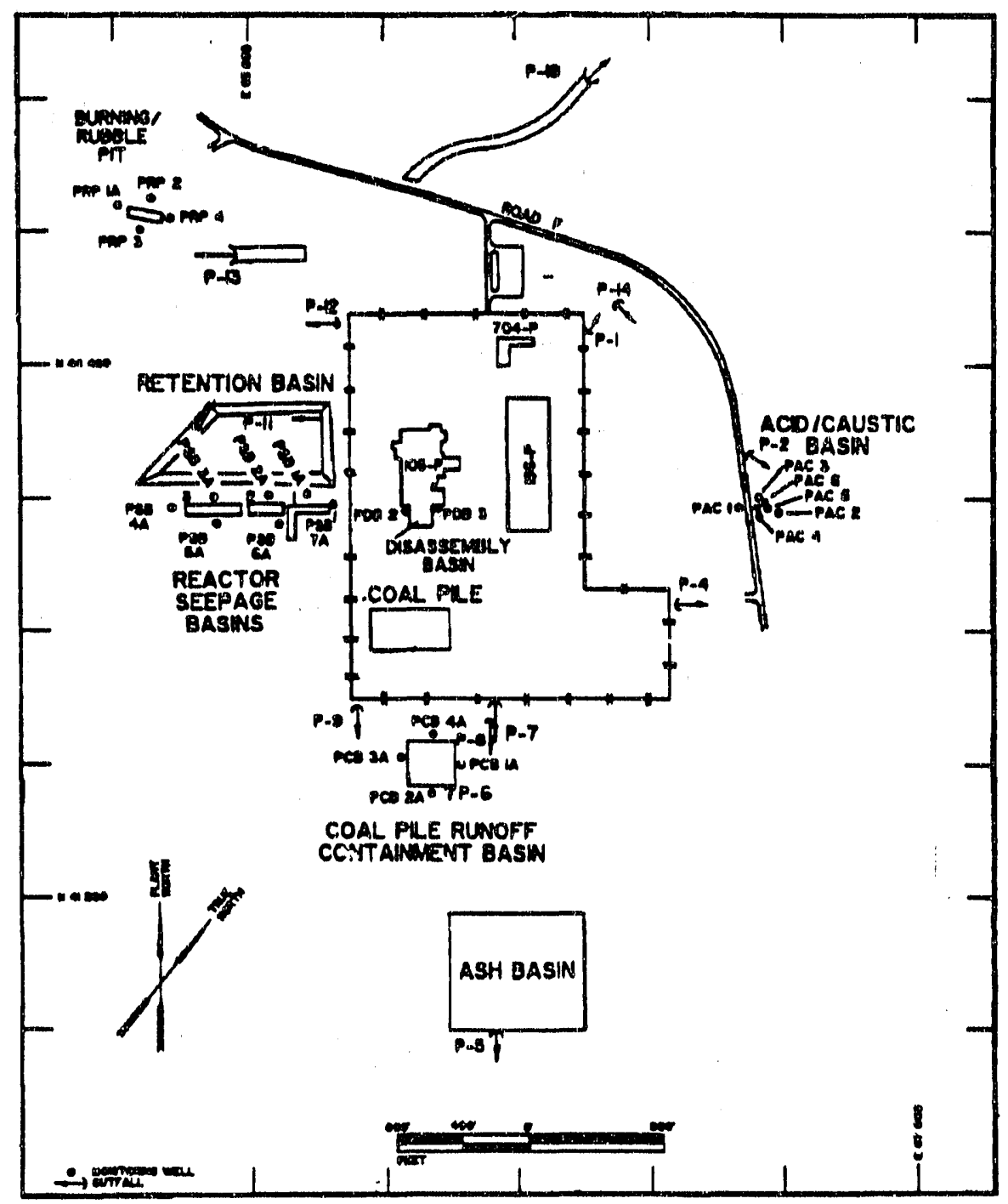

Figure 2.70. P Area Showing the Locations of the Reactor Seepage Basins and Monitoring Wells

Table 2.16. Tritium Concentrations in P-Area Seepage Basin Wells (pCl/mL).

Well

\begin{tabular}{crrrrrrr} 
Number & 1982 & 1983 & 1984 & 1985 & 1986 & 1987 & 1988 \\
\hline $1 A$ & 200,000 & 32,000 & 99,000 & 320,000 & 180,000 & 219,000 & 222,250 \\
$2 A$ & 220,000 & 130,000 & 120,000 & 170,000 & 160,000 & 140,000 & 146,750 \\
$3 A$ & 170,000 & 120,000 & 140,000 & 130,000 & 49,000 & 128,000 & 97,000 \\
$4 A$ & 34 & 22 & 91 & 61 & 3,400 & 141,000 & 5,600 \\
$5 A$ & 37 & 1,300 & 1,200 & 49 & 40 & 209 & 36 \\
CA & 190,000 & 210,000 & 170,000 & 170,000 & 190,000 & 142,000 & 92,425 \\
$7 A$ & 140,000 & 76,000 & 68,000 & 150,000 & 53,000 & 46,900 & 16,325
\end{tabular}






Figure 2.71. The Transport of Tritium at the Savannah River Site During the Period 1952 to 1988 (number are in Curies) 


\section{Tritium Concentrations and Transport at SRS}

to surface water bodies or to seepage basins. A part of the water released to seepage basins will enter the ground and become part of the groundwater. After release, the tritium will become part of the hydrologic cycle on the plant site, leading to some redistribution of the form and location of the tritium before it moves beyond the SRS boundary.

Figure 2.71 illustrates the relationship between the facility releases and the redistribution that takes place at SRS before the tritium leaves SRS. The total atmospheric releases between 1952 and 1988 consisted of 23.8 million $\mathrm{Ci}(98 \%$ of the atmospheric releases) that were directly released to the atmosphere from facility stacks and 410,000 $\mathrm{Ci}(2 \%)$ that resulted from evaporation of tritiated water in liquid releases to seepage basins or lakes.

Some of the tritium released to the atmosiphere is involved in the hydrologic cycle of the environment insicle the SRS boundary. An estimate of the rernoval and cycling of tritium by the SRS environment before transport beyond the SRS boundary can be made on the basis of the measured concentrations of tritiated air moisture, tritiated air hydrogen, and tritiated rain water. The deposition of rainwater tritium inside the site boundary is calculated by summing the product of the concentration and the rainfall rate along the gradient of rainfall concentration demonstrated in this chapter (Figure 2.72). The same procedure can be followed for deposition of tritiated water vapor and tritiated hydrogen where the deposition velocity for each form of tritium is used in place of the rainfall rate. Separate deposition velocities have been used for the vegetation and soil for each form of tritium in the calculations. The values were taken from published estimates of deposition velocity for each of the cases, as presented in Table 2.17.

Table 2.17. Deposition Velocitles (cm/s).

$\begin{array}{ccc}\text { Eorm/Sink } & \text { Veqetation } & \text { Soll } \\ \text { HT } & 0.0 & 0.05 \\ \text { HTO } & 0.4 & 0.04\end{array}$

The distribution of tritium after it has entered the soil can be estimated on the basis of the local hydrologic cycle, under the assumption that tritiated water will act as other water. A review of the available publications, and the meteorological and hydrological data provided the annual components for SRS conditions shown in Table 2.18.

Approximately $620,000 \mathrm{Ci} \mathrm{(2.6 \% )}$ of the total tritium released entered the hydrologic cycle inside the SRS boundary. However, most of this tritium $(543,000 \mathrm{Ci}$ or $2.3 \%$ ) reentered the atmosphere through evapotranspiration from the vegetation. Only $63,000 \mathrm{Ci}(0.3 \%)$ entered the groundwater where significant decay of the tritium could take place before the tritiated water moved beyond the plant boundary.

Table 2.18. Components of the Hydrologic Cycle at SRS.

Component

Precipitation

Runoff

Evaporation

Seepage to

Groundwater

Deep Layers
Annual Amount (in.) Percent

48

3

100

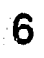

63

30

15

31

2 
The situation is somewhat different for seepage basin releases where liquid tritiated water is purposely put into the groundwater to allow time for radioactive decay of the tritium to nonradioactive helium. Of the approximately 3 million $\mathrm{Cl}$ of tritium released to seepage basins between 1952 and $1988,490,000 \mathrm{Ci}$ $(16 \%)$ have decayed before leaving SRS, and 1.7 million $\mathrm{Cl}(56 \%)$ remain in the ground where much of it will decay before it is transported offsite. The rest of the seepage basin releases have already left the site. Approximately $500,000 \mathrm{Ci}(17 \%)$ have entered surface streams or lakes and left SRS through the Savannah River, and $330,000 \mathrm{Ci}(11 \%)$ nave entered the atmosphere by evaporation.
Between 1954 and 1988, liquid tritiated water has been released into six surface stream drainages: Lower Three Runs Creek, Steel Creek, Pen Branch, Four Mile Creek, Upper Three Runs Creek, and Beaver Dam Creek. Since construction of Par Pond in 1956, releases to Lower Three Runs have passed through Par Pond. Since 1985, releases to Steel Creek have passed through L Lake. Of the approximately 1.09 million $\mathrm{Cl}$ of tritium $(72 \%)$ released directly to surface waters and $430,000 \mathrm{Cl}(28 \%)$ entering surface waters from seepage basins, 1.44 million $\mathrm{Cl}$ (94\%) moved offsite into the Savannah River. The remaining $85,000 \mathrm{Cl}$ evaporated into the atmosphere from the cooling lakes.

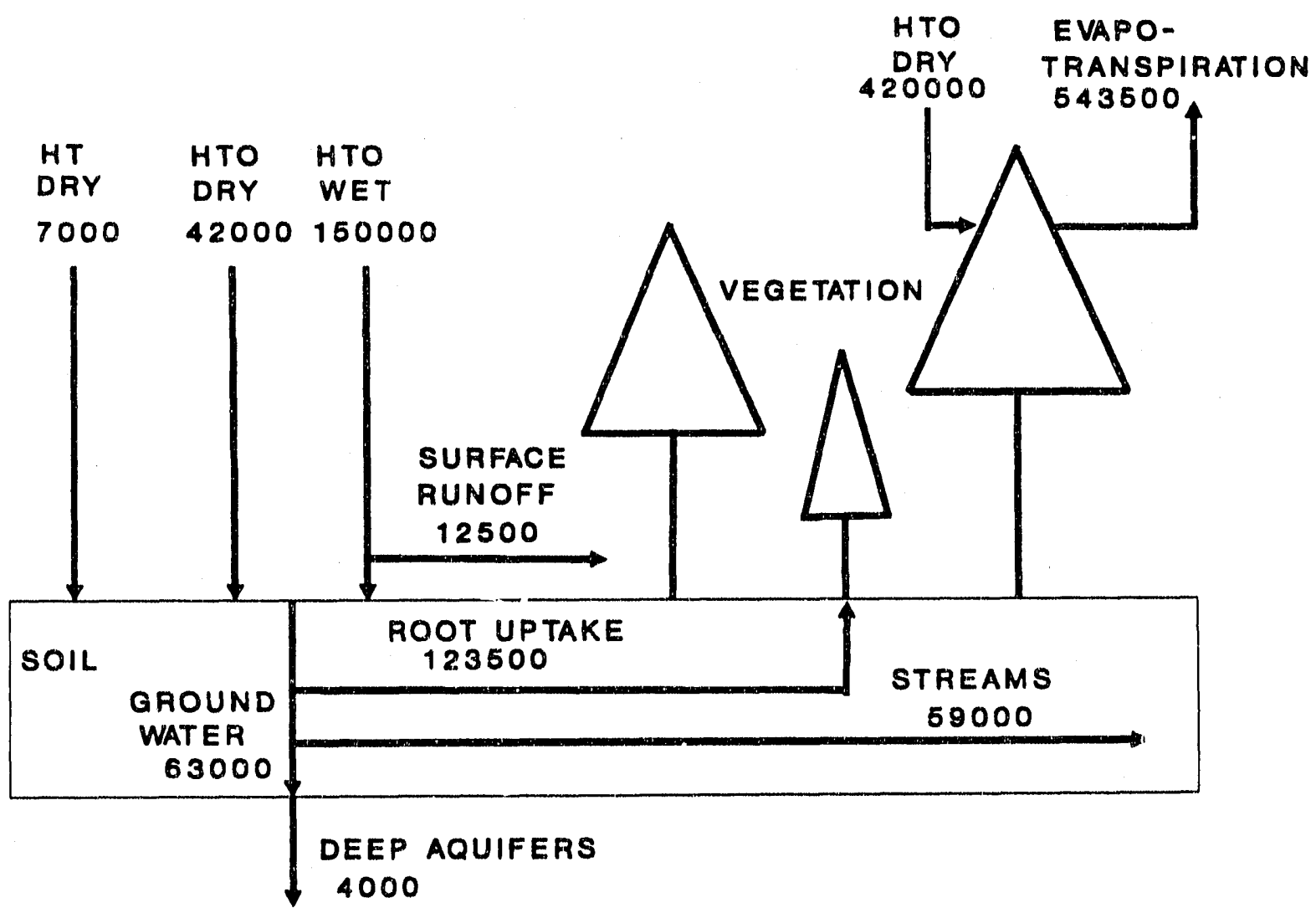

Figure 2.72. The Cycling of Tritium (in Curies) Released to the Atmosphere at SRS from 1952-1988 


\section{Tritium Concentrations and Transport at SRS}

The other major repository of tritium onsite is the Low-Level Waste Burial Ground. Of the 4.2 million Ci of tritium buried, only 1.5 million $\mathrm{Cl}$ remained at the end of 1988. Almost all of the decrease in the inventory is due to radioactive decay. A small amount of tritium is known to have left the burial ground by way of Four Mile Creek. It is accounted for in the total tritium measured downstream from the release point but cannot be differentiated from tritium entering Four Mile Creek from the separations area seepage basins.

The main paths for tritium leaving SRS are by transport in the atmosphere and in site streams to the Savannah River. Since site startup in 1952 through 1988, 24 million Ci of tritium (94\%) have left the plant site through the atmosphere and 1.4 million $\mathrm{Ci}(6 \%)$ have left through the Savannah River.

\section{Tritlum Cycling Within 100 Kilometers of SRS}

Tritium cycling in the environment near SRS can be estimated by the same procedure that was used to determine the magnitude of cycling inside the SRS boundary. The deposition within a radius of $100 \mathrm{~km}$ indicates that much of the tritium interacts with the local environment in the vicinity of SRS (Table 2.19).

The results of the calculation indicate that almost one-third of the tritium released has become part of the hydrologic cycle before leaving the $100-\mathrm{km}$ zone around SRS. The redistribution in the environment can be estimated by using Table 2.18.

These calculations show (see Table 2.20) that even though $29 \%$ of the tritium released interacts with the environment in the vicinity of SRS, two-thirds of the interaction is deposition followed by almost immediate re-evaporation
Table 2.19. Deposition of Tritium Within $100 \mathrm{Km}$ of SRS.

\begin{tabular}{|c|c|c|}
\hline Mechanism & $\begin{array}{c}\text { Total } \\
\text { Deposition } \\
\text { 1954-1988 }\end{array}$ & $\begin{array}{c}\text { Percent o: } \\
\text { Relegse }\end{array}$ \\
\hline Water Vapor & & \\
\hline $\begin{array}{l}\text { Vegetation } \\
\text { Soil } \\
\text { Hydrogen }\end{array}$ & $\begin{array}{r}4,590,000 \\
460,000\end{array}$ & $\begin{array}{r}20 \\
2\end{array}$ \\
\hline Soil & 100,000 & $<1$ \\
\hline Rain & $1,660,000$ & 7 \\
\hline Total & $6,810,000$ & 29 \\
\hline
\end{tabular}

from the vegetation. Another $20 \%$ of the deposited tritium is eventually re-evaporated from the soil, either from the soil surface or through uptake by the vegetation. Therefore, only $10 \%$ of the deposited tritium, or $2.7 \%$ of the total releases, has become part of the groundwater, and less than $0.2 \%$ has percolated to the deeper layers of the soil. From this analysis, it can be concluded that most of the tritium released from SRS does

Table 2.20. Redistribution of Tritium in the Hydrologic Cycle in the Vicinity of SRS.

$\begin{array}{lrrr}\text { Mechanism } & \begin{array}{c}\text { Amount } \\ \text { Eercent } \\ \text { Evaporation }\end{array} & \begin{array}{c}\text { 1954-88* } \\ \text { sition }\end{array} & \begin{array}{c}\text { Percent } \\ \text { Belease }\end{array} \\ \text { Soil } & 1,390,000 & 20 & 5.8 \\ \text { Vegetation } & 4,580,000 & 67 & 19.2 \\ \text { Fun-off } & 140,000 & 2 & 0.6 \\ \text { Groundwater } & 650,000 & 10 & 2.7 \\ \text { Deep Layers } & 50,000 & 1 & 0.2 \\ & & & \\ \text { * Curies } & & & \end{array}$


not remain in the local environment but becomes part of the globalinventory of tritium.

The Fate of SRS Tritium in the Global Environment

The fate of SRS tritium, once it has been released to the environment, has been assessed by using the global compartment model described in NCRP Report No. 62 (NCRP 1979a). This model was developed to determine the dose to the worldwide population from all tritium sources. As described in Chapter 1 , the main source of tritium is the bombtritium released to the upperatmosphere during nuclear testing in the 1950 s and early 1960s. Tritium concentrations in air moisture and streams have been used to validate this model with reasonable success.

The model is based on seven compartments, which are the main global reservoirs for water. The compartments are the atmospheric moisture, soil moisture, groundwater, surface fresh waters (rivers and lakes), inland saline surface waters, the wellmixed surface ocean, and the deep ocean. Tritium is assumed to move with the water. The transport of waterbetween compartments is based on the generalized global water budget.

The fate of SRS tritium was estimated by using the SRS atmospheric and stream

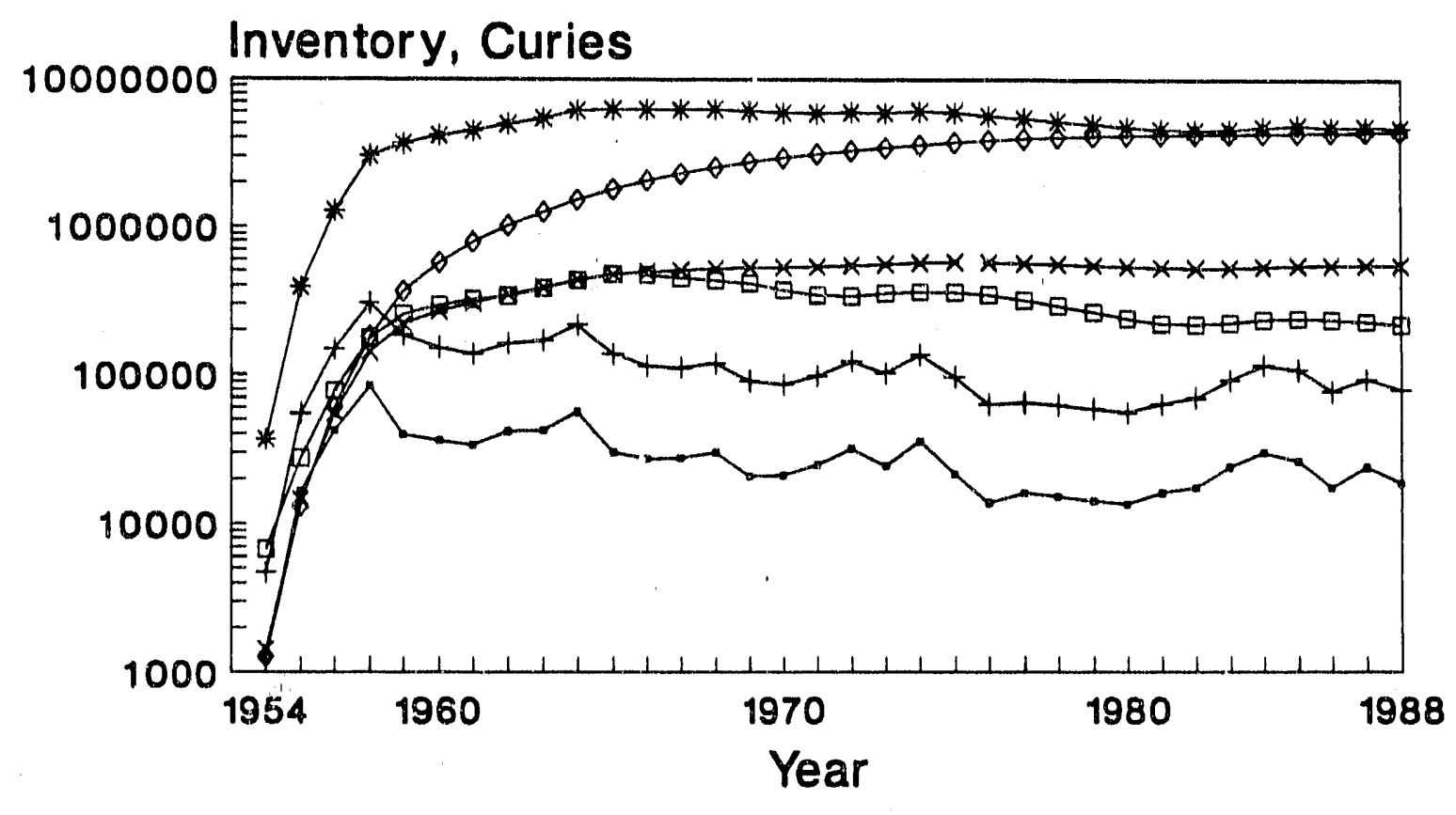

- Atmosphere $\rightarrow$ Soil $\rightarrow$ Surface of Ocean
$\rightarrow$ River \& Lakes $*$ Groundwater $\rightarrow$ Deep Ocean

Figure 2.73. The Global Distribution of SRS Tritium Releases According to the NCRP Seven-Compartment Model 
releases as input for the model. The tritium released to the burial ground and the tritium that still resides under the seepage basins was not included since it has not left the SRS. The results are illustrated in Figure 2.73. The results indicate that most of the tritium is rapidly moved to the surface ocean. After only $10 \mathrm{yr}, 70 \%$ of the tritlum remaining after radioactive decay is in the surface ocean. The movement into the deep ocean is somewhat slower, but at the end of 1988, $91 \%$ of the total tritium remaining in the environment from SRS releases is in either the surface $(47 \%)$ or deep ocean $(44 \%)$

The tritium in the ocean is greatly diluted by the large mass of water. The calculated surface ocean concentration due to SRS releases is only $0.0002 \mathrm{pCl} / \mathrm{ml}$. The concentration in the deep ocean is calculated to be even less, $0.000003 \mathrm{pCl} / \mathrm{ml}$.

The tritium in the atmosphere and soil have decreased slowly since a peak in 1957. This is a reflection of the trend of decreasing SRS releases following the peaks in the early 1950s. The decrease in the surface and groundwater tritium inventory is slower, with peaks in 1965 and 1973, respectively. This is a reflection of the slower turnover of groundwater.

Because of the rapid distribution and dilution of tritium in the global water reservoir, the consequences of tritium released from SRS nuclear facilities are quite small. 
RELATIONSHIP OF DOSE TO RISK AND HEALTH EFFECTS

\section{lonizing radiation}

lonizing radiation is radiation that strips electrons from matter through which it passes. The interaction of lonizing radiation with biological systems can produce, through a series of chemical and physical reactions, permanent changes in the genetic material of the cell. These changes (mutations) may cause abnormal functioning within the cell or may lead to cell death.

The nature of radiation-induced cellular changes is dependent upon the magnitude of the dose and the rate at which it is received. For the low doses and dose rates encountered in the environment from SRS releases, three principal types of effects are potentially significant and are described below:

- cancer induction,

- genetic effects, and

- teratological effects.

Most important from the standpoint of total societal risk from exposures to low-level lonizing radiation are the risks of cancer and genetic mutations. These are believed to be stochastic effects; i.e., an increase in dose increases the probability of the effect, but the severity of the effect is independent of the dose. An illustration of this approach to the dose-response relationship is provided in Figure 3.1.

As seen in the figure, a characteristic of stochastic risks is the absence of a threshold. In other words, it is conceivable that any dose of radiation, no matter how small, might give rise to a cancer or a genetic effect. On the
Stochastic Rlaks

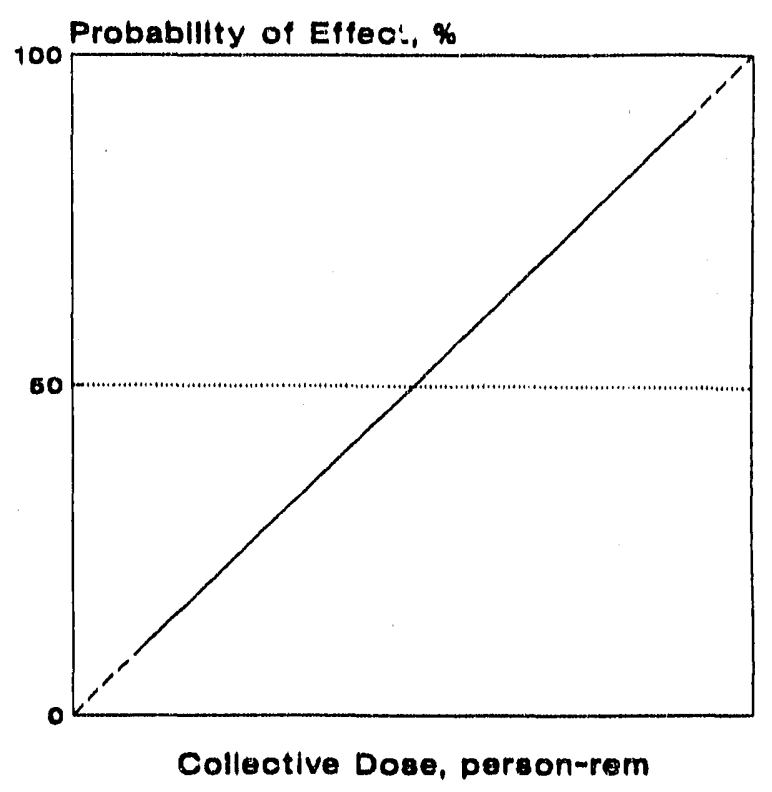

Figure 3.1. Dose Response Relationship for Stochastic Effects

other hand, there is no way to be certain that agiven dose, no matter how large, has caused or ultimately will cause an observed cancer in an individual.

\section{EPA RISK ESTIMATES FOR LOW-LET RADIATION}

\section{Cancer Risk Estimates}

LOW-LET (low linear energy transfer) radiation is sparsely ionizing radiation such as the energetic electrons produced by beta particles, $X$ rays, and gamma rays. Most of the radioactive materials released from the SRS, including tritium, emit low-LET radiation during the process of radioactive decay. It is for this type of radiation that most of the observations of radiation-induced cancers in humans have been made. Observed groups include Japanese atomic bomb survivors and 
medical patients treated with therapeutic radiation.

Advisory and regulatory agencies have generally used the BEIR III linear dose response model (NAS 1980) for estimating health effects from low-LET radiation. The EPA's risk assessment methodology makes use of this model, but incorporates adjustments for age sensitivity and age distribution in the general population. Based on this approach, the EPA has adopted a central estimate for lifetime risk of fatal cancers from lonizing radiation. The methodology used by the EPA is described in detail in a recently issued EPA report (EPA 1989a).

The EPA central estimate of lifetime risk, approximately 400 fatal cancers per million person-rad (EPA 1989b), incorporates the most conservative model assumptions used by the BEIR III committee. As described in the EPA report, there is some evidence that the risk level may be on the order of 1200 fatal cancers per million person-rad (DOE 1988), but the conservatisms inherent in the model suggest that the larger value may be considered an upper limit on the fatal cancer risk. Therefore, in proposed regulations which govern radioactive releases to the atmosphere, the EPA has employed the central estimate of 400 fatal cancers per million person-rad as the figure-of-merit for risk assessment (see Table 3.1).

\section{Genetic Effects Estimates}

Genetic effects, in this context, are stable, heritable changes induced in the germ cells (eggs or sperm) of individuals exposed to lonizing radiation. These changes are transmitted to the progeny of these individuals and may only be expressed in the progeny and/or in subsequent generations. Genetic effects, in the form of a mutation or chromosomal aberration, may appear in the first generation following the radiation exposure or may not appear until many generations later. Alternately, there may be no expression of a genetic effect throughout the 30 generations or so required for complete expression of a genetlc change.

Because genetic effects may vary greatly in severity, the EPA genetic risk factor includes only those disorders and traits that may be expected to cause a serious handicap within the llfetime of a given generation. The EPA assesses risks to progeny and subsequent generations based on the parents' radiation dose up to age 30 (the current median age for reproduction). Because there are no comparable human data, the estimates have been derived from the extrapolation of animal data to man. The information available on hereditary clefects among the children of atomic bomb survivors, however, does provide a degree of confidence that the animal data do not underestimate the genetic risks of ionizing radiation for humans.

The nominal incidence of genetic damage estimated by the EPA is 260 genetic effects permillion liveborn per generation. This value is based on a 30-yr reproductive generation and includes the potential expression of an effect in all subsfquent generations. The range established for this risk factor is 60 to 1100 genetic effects per million liveborn per rem per reproductive generation ( $30 \mathrm{yr}$ ).

\section{Teratological Effects Estimates}

Teratological effects are developmental effects caused by radiation exposure to fetuses. Such defects include mental and growth retardation, microcephaly (reduced head size), and increased mortality (especially infant mortality). Data for teratological effects in humans are limited to the information 
collected on the offspring of atomic bomb survivors. The avallable information, which primarily addresses mental retardation and microcephaly, suggests there is a limited time period that a fetus is sensitive to radiation effects. This time period is estimated to be from week 8 to week 15 of gestation. Based on that period of radiosensitivity, the EPA has established a r.ominal risk factor for mental retardation of 4000 effects per million person$\mathrm{rad}$ at 8 to 15 weeks of gestation with a range of 2500 to 5500 effects per million person-rad.

\section{Summary of EPA Health Effects Estimates} for LOW-LET Radiation

The radiation risk factors adopted by the EPA are summarized in Table 3.1. Nominal risk factors as well as upper and lower limirs have been included. The nominal health effects estimates have been used in this report to assess the impact of SRS tritium releases.

\section{TRITIUM EXPOSURE ANC DOSE TO MAN}

Tritlum in the environment becomes an exposure risk to man when it is inhaled, absorbed through the skin, oringested in food or drinking water. Tritlum does not contribute to the external radiation dose because the energy of the beta particle is too weak ti penetrate the sensitive tissues of the body such as the lens of the eye and the basal layer of the epidermis (ICRP 1978).

The magnitude of the risk irom tritium is dependent upon whether it is present in a form that is biologically active (water or water vapor) or inert (elemental gas). Significant amounts of both forms of tritium are releasad

Table 3.1. Summary of Low-LET Radiation Risk Factors.

$\begin{array}{ccc}\text { Nominal } & \text { Range } \\ \text { Significant } & \text { Risk Factor of Estimates } \\ \text { (pisk } & \text { Exposure Perlod million persen-rad) }\end{array}$

Somatic:

Fatal cancers

Lifetime

390

$120 \cdot 1200$

All cancers

Lifetime

620

$190-1900$

Genetic:

Severe hereditary

defects, all

generations

$30-y r$

260

$60 \cdot 1100$

reproductive

generation

Teratologic:

Severe mental

Weeks 8 - 15

4000

$2500 \cdot 5500$

retardation

of gestation 
to the environment from the SRS. Additionally, a minor amount (less than $1 \%$ ) is released in an organic form, tritiated methane.

\section{Distribution and Retention of Tritium in the Body}

\section{Tritiated Water}

Inhalation and absorption. Essentially all of the tritium inhaled in the form of water vapor will be absorbed by and retained in body fluids, and will do so within seconds (NCRP 1979a, ICRP 1978). Tritium may also be absorbed through the skin during periods of exposure to tritiated water. For an average person ("Reference Man"), the amount absorbed is approximately equal to $50 \%$ of that inhaled (ICRP 1974). Tritium absorbed through the skin will be transported to, and distributed among, body fluids via the same mechanisms as tritium introduced by inhalation.

Ingestion. Ingested tritiated water is assumed to be completely and instantaneously absorbed from the gastrointestinal tract and mixed rapidly with body water so that, at all times following ingestion, the concentration in sweat, sputum, urine, blood, insensible perspiration, and expired water vapor is the same (ICRP 1978).

Biological fate. Tritium that is uniformly distributed in body fluids will be eliminated at the same rate as ordinary water. The rate of elimination may vary considerably due to such factors as fluid intake, metabolism, and ambient temperature. The time required to eliminate $50 \%$ of the tritiated water present in the body ranges from 4 to 18 days. There is some evidence for longer tritium retention times in other body compartments, but this is bellieved to represent less than $10 \%$ of the whole body dose from tritiated water (ICRP 1978). For internal dose purposes, the ICRP assumes that tritiated water is uniformly distributed in all soft tissues at any time following intake and ellminated exponentially with a hali-time of 10 days.

\section{Elemental Tritlum}

When tritium is present in the atmosphere in an elemental form, it represents a very minor exposure hazard. The risks associated with inhalation and skin absorption are essentially eliminated in the case of elemental tritium because its low solubility prevents its absorption by body fluids. Only about $0.004 \%$ of the tritium entering the body is converted to tritiated water and retained in body fluids (NCRP 1979a).

The only direct hazard from exposure to elemental tritium is the dose received by the lungs when the tritiated gas is inhaled, but ihis is an insignificant source of exposure from SRS operations. During a typical year, the average concentration of elemental tritium at the site perimeter (about $90 \mathrm{pCi} / \mathrm{m}^{3}$ ) would deliver a lung dose equivalent of less than $0.0001 \mathrm{mrem}$ if inhaled continuously for a year.

\section{Organic Forms}

Inhalation. Many forms of tritiated organic compounds (e.g., thymidine) are of such low volatility that the probability of their being inhaled is quite small. In circumstances where they might be inhaled, it is assumed that they are instantaneously and completely translocated to the blood without a change in chemical form. Once in the bloodstream, there is some potential for partial catabolism to tritiated water. 
Ingestion. When tritiated organic compounds are ingested in food or water, a large fraction may be broken down in the gastrointestinal tract, producing tritiated water. In rodents, for example, more than $90 \%$ of the tritlated thymidine is broken down in the gastrointestinal tract, and only about $2 \%$ is actually incorporated into DNA. Tritlum may be incorporated into lipids, proteins, and carbohydrates at much higher percentages (van den Hook 1979). However, it is the potential incorporation of radioactive materials into DNA that presents a less probable but more serious threat to biological systems (NCRP 1979a).

\section{Tritlum Incorporation in DNA}

The incorporation of tritium into DNA may result in undesirable genetic or somatic changes. The radioactive decay of a tritium atom located on a DNA molecule can result in a break or rearrangement of a DNA segment. However, for low doses and low dose rates, the biological effect of such an event is small in relation to the effect of ionization on the other components of the cell (NCRP 1979a, NCRP 1979b).

\section{TRITIUM TRANSPORT AND DOSE MODELS}

Tritium can be measured in food, air, and water. Because it is impractical to collect sufficient monitoring data to determine individual doses in a large population group, radiation doses to offsite populations are calculated with mathematical models. These models use known transport mechanisms for atmospheric and liquid releases and known major pathways of exposure to man. Environmental measurements of tritium oxide (which is released during normal operations) are used to verify atmospheric dispersion in the transport models.

\section{Calculational Models}

The models used for calculating the SRS average annual offsite doses are the transport and dose models developed for the nuclear industry (NRC 1977a and 1977b) to assess the effects of operations of licensed nuclear facilities. The models are implemented at SRS in the following computer programs:

\section{Atmospheric Releases}

- MAXIGASP: calculates maximum and average doses to offsite individuals.

- POPGASP: calculates offsite population doses.

\section{Llquid Releases}

- LADTAP: calculates both maximum and average doses to offsite individuals and doses to offsite populatioris.

MAXIGASP and POPGASP are SRL. modified versions of the Nuclear Regulatory Commission programs XOQDOQ and GASPAR. The modifications were made to accommodate the input of physical and biological data that are specific to the SRS. The basic calculations in the XOQDOQ and GASPAR programs have not been modified. LADTAP is an essentially unaltered version of the NRC code of the same name.

\section{Modeling Atmospheric Dispersion of Radioactive Releases}

The routine atmuspheric transport of radioactive materials from the SRS is evaluated on the basis of meteorological conditions measured continuously at seven onsite and one offsite meteorological towers. The towers relay wind speed, direction, and aimospheric stability information at 5-sec intervals to the Savannah River Laboratory 
via the WIND (Weather INformation and Display) system. A data base of this information containing the $60-\mathrm{min}$ average values for the period $1982-1986$ is accessed by the dispersion codes to determine sitespecific atmospheric dispersion characteristics.

The dispersion of an atmospheric release from SRS is modeled using the nuclear industry computer program, XOQDOQ (Sagendorf and Goll 1976). XOQDOQ computes concentrations in the plume as a function of downwind distance and compass sector. At the user's option, the plume can be depleted due to dry deposition and/or radioactive decay. Also at the user's option, plume concentrations can be reduced by taking into account the upward displacement of the plume resulting from thermal buoyancy and/ or momentum effects. This option is not used at SRS; i.e., no credit is taken for plume rise.

The plume concentration information generated by XOQDOQ is then used by a dose modeling program, GASPAR, to estimate doses to offsite indiviciuals and populations. GASPAR (Eckerman 1980) estimates doses from a number of pathways, which are illustrated in a general sense in Figure 3.2.

The doses produced by GASPAR are reported on a pathway-specific basis as follows:

- Plume-externaldosefrom radioactive materials suspended in the atmosphere

- Ground - external dose from radioactive materials deposited on the ground

- Inhalation - internal dose from inhalation of radioactive materials present in the plume

- Vegetation - internal dose from consumption of contaminated crops

- Milk - internal dose from consumption of milk produced in a contaminated area

- Meat -internal dose from consumption of meat products produced in a contaminated area.

The method of modeling the concentration of radioactivity as it moves through these pathways is fairly consistent from radionuclide to radionuclide. There is, however, a significant modification made for tritium. For dose purposes, it is assumed that the tritium concentration in vegetation does not exceed $50 \%$ of the tritium concentration in atmospheric water vapor. This reflects the fact that not all of the water content of a plant is derived from water vapor impacted by SRS operations. Distant sources of water such as rain have very little tritium content and therefore dilute the tritium concentration of the plant.

MAXIGASP. The calculations required by XOQDOQ and GASPAR to estimate maximum and average individual doses are performed at SRS using the computer program MAXIGASP. MAXIGASP calculates annual average air and ground deposition concentrations per unit release at a number of points along the site boundary in each of the 16 compass sectors.

The main outputs from the program are the doses at the location of the maximum effective dose equivalent to individuals along the SRS perimeter. The maximally exposed individual is assumed to reside continuously at the location of high.9st exposure. This individual is also assumed to have living and eating habits which maximize his dose. These assumptions provide a ceiling on doses from atmospheric releases because no such individual is believed to exist.

The average dose at the site perimeter is calculated for a number of locations along the 


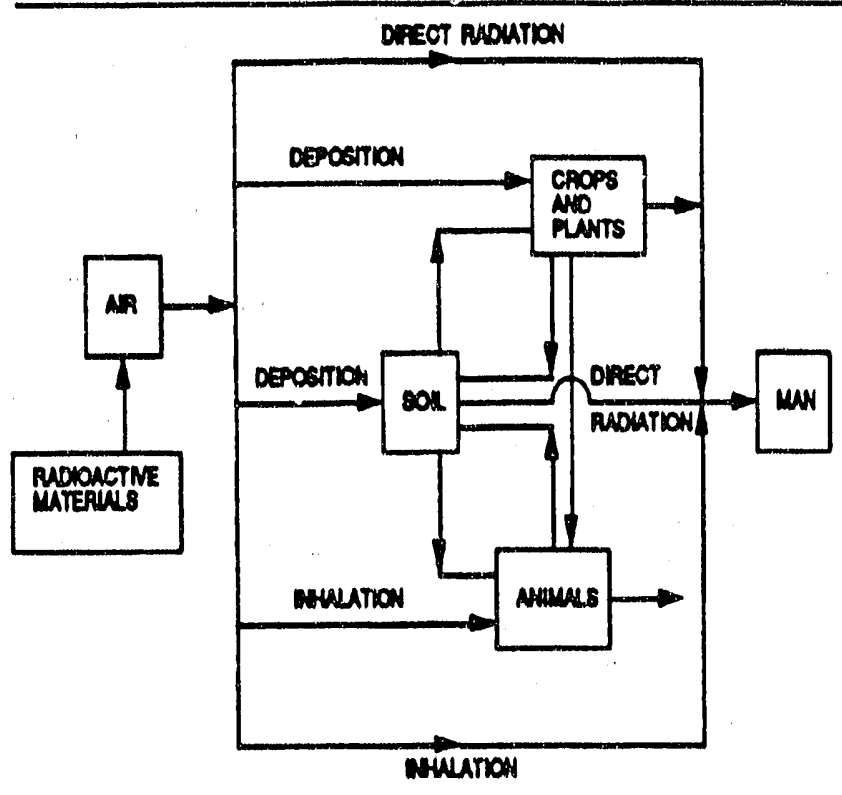

Figure 3.2. Simplified Pathways Between Radioactive Materials Released to the Atmosphere and Man

perimeter, and these data are then averaged. Calculations for average individual doses are made with living and eating parameters that are more realistic than those for a maximum individual.

The parameters used to calculate dose's with MAXIGASP are shown in Table 3.2.

POPGASP. The calculations required by XOQDOQ and GASPAR to estimate population doses from atmospheric releases are performed at SRS using a computer program called POPGASP. POPGASP calculates annual average air and ground deposition concentrations per unit release for each of 160 segments (16 wind direction sectors at 10 distances per sector) within a $80-k i n$ radius of the release location.

In additionto sector-specificmeteorological information, POPGASP uses sector-specific data on population density and milk, meat, and vegetable production and consumption. These data are quite extensive and are available for review in the SRS Environmental Reports published annually. With respect to the human parameters used in POPGASP, the key values are presented in Table 3.2.

\section{Modelling Doses from Liquid Releases}

The consequences of liquid releases from the SRS are modeled using an NRC computer program called LADTAP (Liquid Annual Doses To All Persons) (Simpson and McGill 1980). The potential pathways of exposure from liquid releases to the environment are shown in Figure 3.3.

The pathway-specific doses calculated by LADTAP are grouped into the following five basic categories:

- Potable drinking water - internal dose from consuming drinking water from the Savannah River

- Sports fish and commercial fish internal dose from consuming fish of Savannah River origin

- Salt waterinvertebrates-internaldose from consuming shellfish from estuaries of the Savannah River

- Recreation - external dose from recreation activities in and along the Savannah River (boating, swimming, and fishing)

- Irrigation - internal dose from foods produced by irrigation with Savannah River water. (At this time there is no known use of Savannah River water for irrigation.)

LADTAP estimates individual and population doses at specific downstream locations. The only removal mechanism included in the transport model, as it is used 
Table 3.2. Slite-and Age-Specific Parameters for Atmospheric Releases.

Demographic Data

Population Group

$80-\mathrm{km}$ radius
Population Size.

555,100
Age Distribution, \%

Children Ieens

11.1

18.6

70.3

Adults

\section{Maximum Individual (MAXIGASP)}

Exposure Pathway

Inhalation $\left(\mathrm{m}^{3} / \mathrm{yr}\right)$

Ingestion

Cow's milk (Lyr)

Meat $(\mathrm{kg} / \mathrm{yr})$

Leały vegetables (kg/yr)

Fruits, grains, and other vegetables $(\mathrm{kg} / \mathrm{yr})$

External exposure

Transmission factor for shielding from buildings

\section{Infont}

1400

330

0

0

0

0.7

0.7

3700

.

330

520

Toen

Adult

8000

8000

400

65

42

630

310

110

64

520 


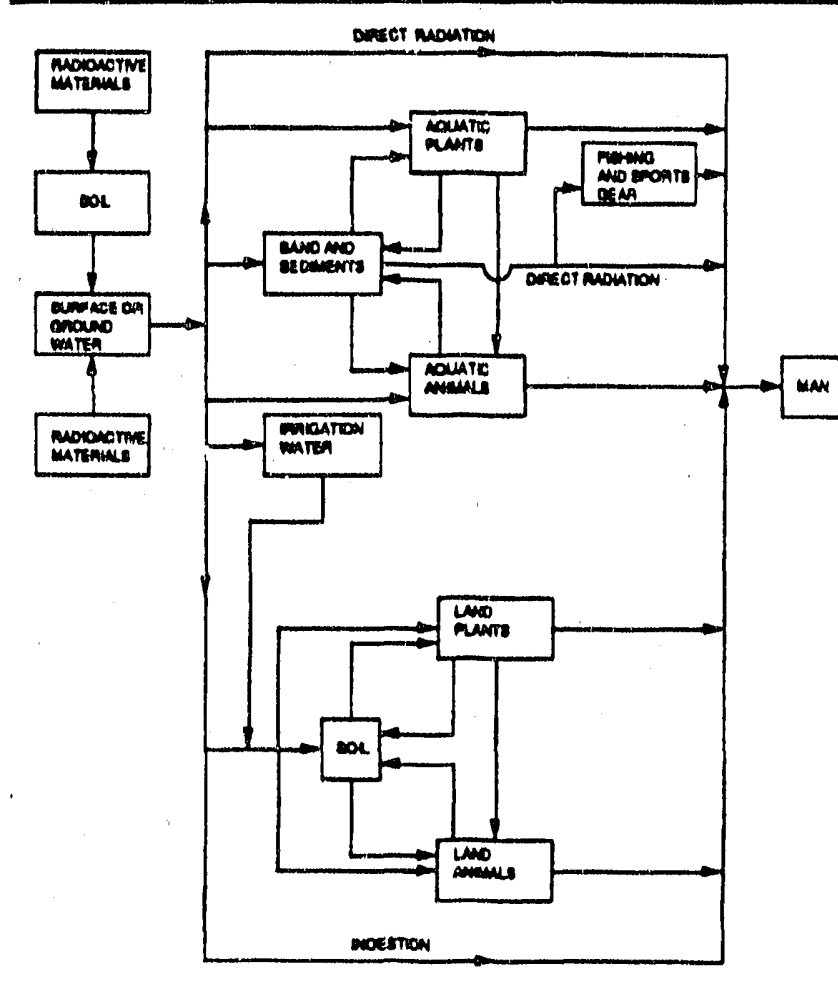

Figure 3.3. Simplified Pathways Between Radioactive Materials Released to Groundwater or Surface Waters and Man

at SRS, is radioactive decay. No credit for adsorption on stream sediments is taken.

The major assumption inherent in the application of LADTAP to SRS releases is that liquid discharges undergo complete mixing in the Savannah River before reaching potentially exposed populations. This assumption is supported by repeated measurements indicating that complete mixing occurs in the river prior to reaching the Highway 301 bridge downstream of the SRS (Du Pont 1988). Tritium calculations, however, are unaffected by this assumption. Doses from SRS tritium releases to the Savannah River are based on measured, not estimated, tritium concentration in the river.
LADTAP generates maximum individual and population doses for all of the exposure pathways identified above. Although standard input values are provided in the LADTAP users' manual, SRS calculations are performed with site-specific information to the extent that it is available. Summary tables of principal input values used in SRS versions of LADTAP are shown in Tables 3.3 and 3.4.

\section{DOE Internal Dose Factors}

To calculate the committed dose equivalent to specific organs and the committed effective dose equivalent to an individual, the dose codes described above access dose factor libraries. The libraries contain radionuclide specific and exposure pathway-specific factors which express the 50-yr committed dose that would result from the intake of a unit quantity of radioactivity, normally 1 becquerel $(1 \mathrm{~Bq})$ or 1 picocurie (1 pCi).

DOE internal dose factors are used at SRS. They are based on methods and data from ICRP 1978 and DOE 1988. (The dose factors used by DOE are in the form of mrem per pCi of intake.)

For tritium oxide, the DOE dose factors are:

- $9.5 \times 10^{-8}$ mrem per $\mathrm{pCi}$ inhaled (includes skin absorption) and,

- $6.3 \times 10^{-8} \mathrm{mrem}$ per $\mathrm{pCi}$ ingested.

\section{VERIFICATION OF MODELS USING MONITORING DATA}

\section{Atmospheric Releases}

The tritium concentrations predicted by MAXIGASP and POPGASP are routinely compared with measured values of tritium in 
Table 3.3. Site- and Age-Speclfic Parameters for Liquid Releases.

Maximum Individual Dose Assessments (LADTAP)

Site Parameters

Savannah River flow rate, liters/sec

170,000 or measured average

Transit time from SRS to Savannah River, hr

24

Shore width factor

0.2

Human Parameters

Water consumption (L/yr)

Fish consumption (kg/yr)

Shellfish consumption $(\mathrm{kg} / \mathrm{yr}$ )

Shoreline recreation (hr/yr)

Swimming (hr/hr)

Boating (hr/hr)

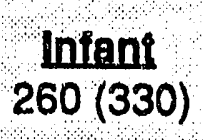

0

0

0

0

0
Maximum Individual

$\frac{\text { Child }}{260(510)}$

Teen $260(510)$

Adult

$370(730)$
11.2

1.7

14

10

60
25.9

3.8

67

10

60
34

5

20

10

60

- The values in parentheses are EPA parameters mandated for use when calculating maximum individual doses to Beaufort-Jasper and Port Wentworth water users.

air to evaluate the performance of the codes. Table 3.5 shows a comparison of calculated and measured tritium oxide concentrations in air at the site perimeter. Other comparisons of predicted and measured concentrations have been performed (Marter 1984) and have exhibited similar results. Thus, the available data suggest that calculated concentrations of tritium in air are generally conservative estimates of actual offsite values.

\section{Liquid Releases}

Comparisons of LADTAP-predicted tritium concentrations with measured values are made for three downstream locations that are important in terms of dose calculations: (1) just below the SRS, (2) at the Beaufort-Jasper water treatment plant, and (3) at the Port
Wentworth water treatment plant. These comparisons are used to enhance LADTAP's ability to predict the downstream concentrations of other radionuclides by providing known dilution factors.

\section{IMPACT OF SRS TRITIUM RELEASES ON THE OFFSITE POPULATION}

The computer codes MAXIGASP, POPGASP, and LADTAP have been used to calculate effective dose equivalents (EDEs) theoretically received by segments of the offsite population from tritium exposure over the course of SRS operations. The results are presented in Tables 3.6 and 3.7 for doses attributable to atmospheric and liquid releases, respectively. Atmospheric tritium release levels have consistently exceeded liquid tritium 
Table 3.4. Site- and Age-Specific Parameters for Llquild Releases.

Average Individual/Population Dose Assessments (LADTAP)

\section{Slite Parameters}

Savannah River flow rate, L/s

Transit time from SRS to Savannah River, hr

Transit time from SRS to water treatment plants, $\mathrm{hr}$

Retention time in water treatment system, hr

Shore width factor

River dilution in estuary

Aquatic food harvest, $(\mathrm{kg} / \mathrm{yr})$

Sport fish

Commercial fish

Saltwater invertebrates
283,200 or measured average

24

72

24

0.2

3

103,700

31,800

299,400

\section{Demographic Data}

\section{Pepulation Group}

$80-\mathrm{km}$ radius

Beaufort-Jasper water users

Port Wentworth water users

Human Parameters

Water consumption (L/yr)

Fish consumption (kg/yr)

Shellfish consumption ( $\mathrm{kg} / \mathrm{yr}$ )

Shoreline recreation (hr/yr)

Swimming (hr/hr)

Boating (hr/hr)
Age Distribution, \% Children Teens Adults

Population Size 555,100

51,000

20,000

18.6

21

11.1

10

70.3

0

0

69

100

Average Individual

\section{Infant}

Chlld

Ieen

Adult

260

260

260

370

3.6

0.33

8.5

0.75

11.3

0

\section{Population (person-hr)}

108,400

8,465

232,000 
Table 3.5. Comparlson of Average Calculated and Measured Concentratlons of Tritium at the Site Boundary.

\begin{tabular}{|c|c|c|c|}
\hline Year & Calculated & Measured & Ratlo:Calc/Mersured \\
\hline 1985 & 190 & 120 & 1.6 \\
\hline 1986 & 88 & 79 & 1.1 \\
\hline 1987 & 81 & 81 & 1.0 \\
\hline 1988 & 87 & 54 & 1.6 \\
\hline
\end{tabular}

reiease levels, and this trend is reflected in the doses to the offsite populations reported in the tables. The tritium dose is the major component of the total dose.

\section{Doses from Atmospherlc Releases}

As shown in Table 3.6, the largest annual dose equivalent theoretically received by an individual occurred in 1958, the year atmospheric releases peaked. Doses to the "maximum" and "average" individuals at the site perimeter in 1958 were 2.48 and 1.01 mrem, respectively. However, the SRS "maximum" individual is a hypothetical person who lives at the SRS boundary and consumes large amounts of milk, meat, and vegetables, all of which are produced near that location. No such individual is known to exist.

With that in mind, it is more realistic to evaluate the impact of SRS operations in terms of the average dose equivalents potentially received. Such doses are calculated based on average exposure parameters (i.e., average breathing and consumption rates) at 320 locations along the site boundary. With this approach, the average dose equivalent over the 35-yr period of plant operation would be on the order of $10 \mathrm{mrem}$. Over a 35-yr period, however, an individual living in the central Savannah River area would receive a dose of approximately 10,325 mrem from exposure to natural sources of radioactivity and an additional 2160 mrem from medical practices and various consumer products (Du Pont 1988). Therefore, the cumulative contribution to dose from SRS atmospheric tritium releases to an average offsite individual at the site boundary would have been less than $0.08 \%$.

Because the contribution of SRS tritium releases to any one individual's total radiation is so small, it is necessary to pool the radiation exposures from a given population if an assessment of potential health risks is desired. The population dose within a $80-\mathrm{km}$ radius is the figure-of-merit frequently used to make such an assessment.

The collective doses to the $80 \mathrm{~km}$ population reported in Table 3.6 are based on 1980 census data $(555,150$ people) and current meteorological and dose factor data. If it is assumed that this population has lived in the SRS vicinity throughout the period of site operation, the total collective dose received by that population through 1988 would be 1300 person-rem. The EPA nominal risk estimate for the number of fatal cancers potentially induced by that collective dose is 0.52 . Conversely, in that same population, at the current fatal cancer frequency of $16 \%$ (EPA 1989b), there will be on the order of 88,820 spontaneous fatal cancers from all other causes. Therefore, it is very unlikely that a relationship between any of the cancer 


\section{Table 3.6. Atmospheric Tritlum Releases and Offsite Doses (1954 - 1988).}

\begin{tabular}{|c|c|c|c|c|c|c|}
\hline & Atm & ric Tritlum $R_{\theta}$ & & Offistie Annua & Cumulative & so Equivalents \\
\hline Year & $\begin{array}{l}\text { Total } \\
\text { Original } \\
\text { Reloase } \\
\text { (C) }\end{array}$ & $\begin{array}{l}\text { HTO } \\
\text { Componont } \\
\left(C^{(C)}\right)^{b}\end{array}$ & $\begin{array}{l}\text { Total } \\
\text { Docay- } \\
\text { Correctod } \\
(\text { Cl) }\end{array}$ & $\begin{array}{l}\text { Max } \\
\text { Ind } \\
\text { EDE } \\
\text { (mrem) }\end{array}$ & $\begin{array}{l}\text { Avg } \\
\text { Ind } \\
\text { EDE } \\
\text { imrem) }\end{array}$ & $\begin{array}{l}\text { 80-km } \\
\text { POP } \\
\text { EDC } \\
\text { DOr-rem }\end{array}$ \\
\hline 1954 & $2.16 E+02$ & & $3.10 E_{4} 01$ & $<0.001$ & $<0.001$ & $\frac{0.1-19 \mathrm{M}}{1.20 \mathrm{E} \cdot 02}$ \\
\hline 1955 & $3.61 E+04$ & & $5.53 E+03$ & 3.79E-02 & 1.55E-02 & $2.00 E+00$ \\
\hline 1956 & $4.69 E+05$ & & $7.60 E+04$ & 4.92E-01 & $2.01 \mathrm{E}-01$ & $2.60 E+01$ \\
\hline 1957 & $1.20 E+06$ & & $2.06 E+05$ & $1.26 E+00$ & 5.15E-01 & $6.66 E+01$ \\
\hline 1958 & $2.36 E+06$ & & $4.28 E+05$ & $2.48 E+00$ & $1.01 E+00$ & $1,31 E+02$ \\
\hline 1959 & $1.05 E+06$ & & $2.01 E+05$ & $1.10 E+00$ & 4.50E-01 & $5,83 E+01$ \\
\hline 1960 & 9.51E+05 & & $1.93 E+05$ & $1.00 E+00$ & 4.08E-01 & $5.28 E+01$ \\
\hline $196 !$ & $8.86 E+05$ & & $1.90 E+05$ & $9.30 E-01$ & $3.80 E-01$ & $4.92 E+01$ \\
\hline 1962 & $1.11 E+06$ & & $2.52 E+05$ & $1.17 E+00$ & $4.76 E-01$ & $6.16 E+01$ \\
\hline 1963 & 1.13E+06 & & $2.71 E+05$ & $1.19 E+00$ & 4.85E-01 & $6.27 E+01$ \\
\hline 1964 & $1.52 E+06$ & & $3.85 E+05$ & $1.60 E+00$ & $6.52 \mathrm{E}-01$ & $8.44 E+01$ \\
\hline 1965 & $7.44 E+05$ & & $2.00 E+05$ & 7.81E.01 & $3.19 \mathrm{E}-01$ & 4.13E+01 \\
\hline 1966 & $6.75 E+05$ & & $1.91 E+05$ & 7.09E-01 & 2.90E-01 & $3.75 E+01$ \\
\hline 1967 & $6.89 E+05$ & & $2.07 E+05$ & 7.23E-01 & 2.96E-01 & $3.82 E+01$ \\
\hline 1968 & $7.62 E+05$ & & 2.42E+05 & 8.00E-01 & 3.27E-01 & $4.20 E+01$ \\
\hline 1969 & $4.96 E+05$ & & $1.66 E+05$ & 5.21E-01 & 2.13E-01 & 2.75E+01 \\
\hline 1970 & $5.13 E+0.5$ & & $1.82 E+05$ & 5.39E-01 & 2.20E-01 & $2.85 E+01$ \\
\hline 1971 & $6.21 E+05$ & & 2.33E+05 & 6.52E-01 & 2.66E-01 & $3.45 E+01$ \\
\hline 1972 & $8.22 E+05$ & & $3.26 E+05$ & 8.63E-01 & $3.53 \mathrm{E}-01$ & $4.56 E+01$ \\
\hline 1973 & $6.01 E+05$ & & $2.52 E+05$ & 6.31E-01 & $2.58 \mathrm{E}-01$ & $3.34 E+01$ \\
\hline 1974 & $9.37 E+05$ & & $4.16 E+05$ & 9.84E-01 & $4.02 E-01$ & $5.20 E+01$ \\
\hline 1975 & $5.18 E+05$ & & $2.43 E+05$ & 5.44E-01 & 2.22E-01 & $2.87 E+01$ \\
\hline 1976 & $3.04 E+05$ & & $1.51 E+05$ & 3.19E-01 & 1.30E-01 & $1.69 E+01$ \\
\hline 1977 & $3.81 E+05$ & & $2.00 E+05$ & $4.00 \mathrm{E}-01$ & 1.63E-01 & $2.11 E+01$ \\
\hline 1978 & $3.60 E+05$ & & $2.00 E+05$ & $3.78 E-01$ & $1.54 \mathrm{E}-01$ & $2.00 E+01$ \\
\hline 1979 & $3.33 E+05$ & & $1.96 E+05$ & 3.50E-01 & $1.43 \mathrm{E}-01$ & 1.85E+01 \\
\hline 1980 & $3.17 E+05$ & & $1.97 E+05$ & 3,33E-01 & $1,36 \mathrm{E}-01$ & $1.76 E+01$ \\
\hline 1981 & $3.95 E+0.5$ & & 2.60E+05 & $4.15 E-01$ & 1.69E-01 & $2.19 E+01$ \\
\hline 1982 & $4.34 E+05$ & & $3.02 E+05$ & 4.56E-01 & $4.86 \mathrm{E}-01$ & $2.41 E+01$ \\
\hline 1983 & $6.18 E+05$ & & $4.54 E+05$ & $6.49 \mathrm{E}-01$ & 2.65E-01 & $3.43 E+01$ \\
\hline 1984 & $7.86 E+05$ & & $6.11 E+05$ & $8.25 \mathrm{E}-01$ & 3.37E-01 & $4.36 E+01$ \\
\hline 1985 & $6.67 E+05$ & 4.87E+05 & 5.51E+05 & 5.15E-01 & 2.10E-01 & $2.72 E+01$ \\
\hline 1986 & $4.25 E+05$ & 2.85E+05 & $3.69 E+05$ & 2.99E-D1 & 1.22E-01 & $1.58 E+01$ \\
\hline 1987 & $5.90 E+0.5$ & $2.70 E+05$ & $5.42 E+0.5$ & $2.84 \mathrm{E}-01$ & 1.16E 01 & $1.50 E+01$ \\
\hline 1988 & $4.62 E_{+} 05$ & $288 E_{+} 05$ & $449 E_{+} 05$ & $3,02 \mathrm{E}-01$ & L24E-01 & $160 E+01$ \\
\hline & $2.42 E+07$ & $1.33 E+06$ & $9.35 E+06$ & $2,45 E+01$ & $1,00 E+01$ & $1.30 E+03$ \\
\hline
\end{tabular}

Notes:

all doses based on undecayed activity. The 1960 to 1964 release data do not include separate estimates of tritlum released to Steel Creek from heat exchanger cooling water discharges.

b The ratio of elemental tritium to tritium oxide is known for the period 1985-1988 based on measurements of elemental and total tritium. Because elemental tritium is an insignificant contributor to dose, the dose calculations for that period were based exclusively on tritium oxide values. The implication for provious years is that tritlum doses have been overestimated, as they were based on the very conservative assumption that all releases were $100 \%$ tritium oxide.

cAnnual releases have been decay-corrected to 01-01-89 to show remaining tritlum inventory.

"Values presented are effectlve dose equivalents (EDEs).

- The population dose equivalents are environmental dose commitments (EDCs) to the population witrin an 80-km radius of the SRS. 
deaths occurring in this population and the releases of tritium to the atmosphere from the SRS will be encountered.

\section{Doses from Llquid Releases}

Dose equivalents potentially received by downstream consumers of Savannah River water and fish are shown in Table 3.7. The dose calculations are based on the total number of curies released to onsite streams during $35 \mathrm{yr}$ of SRS operations. The release levels reflect contributions from all known effluents and seepage basin outcrops. Dose equivalents resulting from drinking treated river water have been calculated for maximum and average individuals and for the populations served by two water treatment plants, both of which are located approximately $160 \mathrm{~km}$ downstream.

As shown in the table, the maximum dose equivalent reported was 0.403 mrem in 1966 for a user of the Port Wentworth or Beaufort Jasper water treatment plant. This maximum value, however, is based on a 2-Lday water consuinption rate and is primarily used for comparison with EPA drinking water standards. More realistic water intake rates are used to generate the "average" downstream individual dose equivalents. However, even at the 2-L/day intake rate, the cumulative dose from liquid tritium releases throughout the period of site operation would be on the order of $7.3 \mathrm{mrem}$. Since this individual's dose from natural and other manmade sources of radiation for that same period would have exceeded 12,000 mrem, it may be concluded that the contribution to downstream individuals' doses by SRS releases to streams is insignificant. This conclusion is further evidenced by the fact that none of the annual doses reported in Table 3.7 exceeded $1 \mathrm{mrem}$.
An EDE of less than or equal to $1 \mathrm{mrem} / \mathrm{yr}$ has beentermed a Negligible Individual Risk Level (NIRL) by the National Council on Radiation Protection and Measurements (NCRP 1987a).

With respect to the effect of liquid tritium releases on the downstream Savannah River population, drinking water doses for users of the Beaufort-Jasper, SC, (51,000 customers) and Port Wentworth, GA, $(20,000$ effective consumers) water treatment plants have also been pertormed. Different terminology is used to describe the two populations to reflect the difference in their compositions. The Beaufort-Jasper plant serves residential areas and, therefore, provides full-scale domestic water service. The Port Wentworth facility serves a commercial complex in which contact with treated Savannah River water is possible for industrial workers who consume tap water and for people in the area who consume locally produced soft drinks. Also, a sugar refining plant uses some of this water in its refining process.

In addition to those two groups of Savannah River water users, dose calculations for consumers of commercial and sport ish harvested from the Savannah River have been included in Table 3.7. If the cumulative tritium doses received by all three of these populations were summed, the collective dose equivalent would be on the order of 200 person-rem and would clearly be dominated by the drinking water pathway. Use of the EPA risk factor to predict the impact of this collective population dose yields an estimated 0.08 fatal cancers in a population of 626,150 people $-100,180$ of whom, at the current fatal cancer rate; will ultimately succumb to cancer-related deaths from all other sources. SUMMARY 
Table 3.7. Liquid Tritum Releases and Offsite Doses (1954 - 1988).

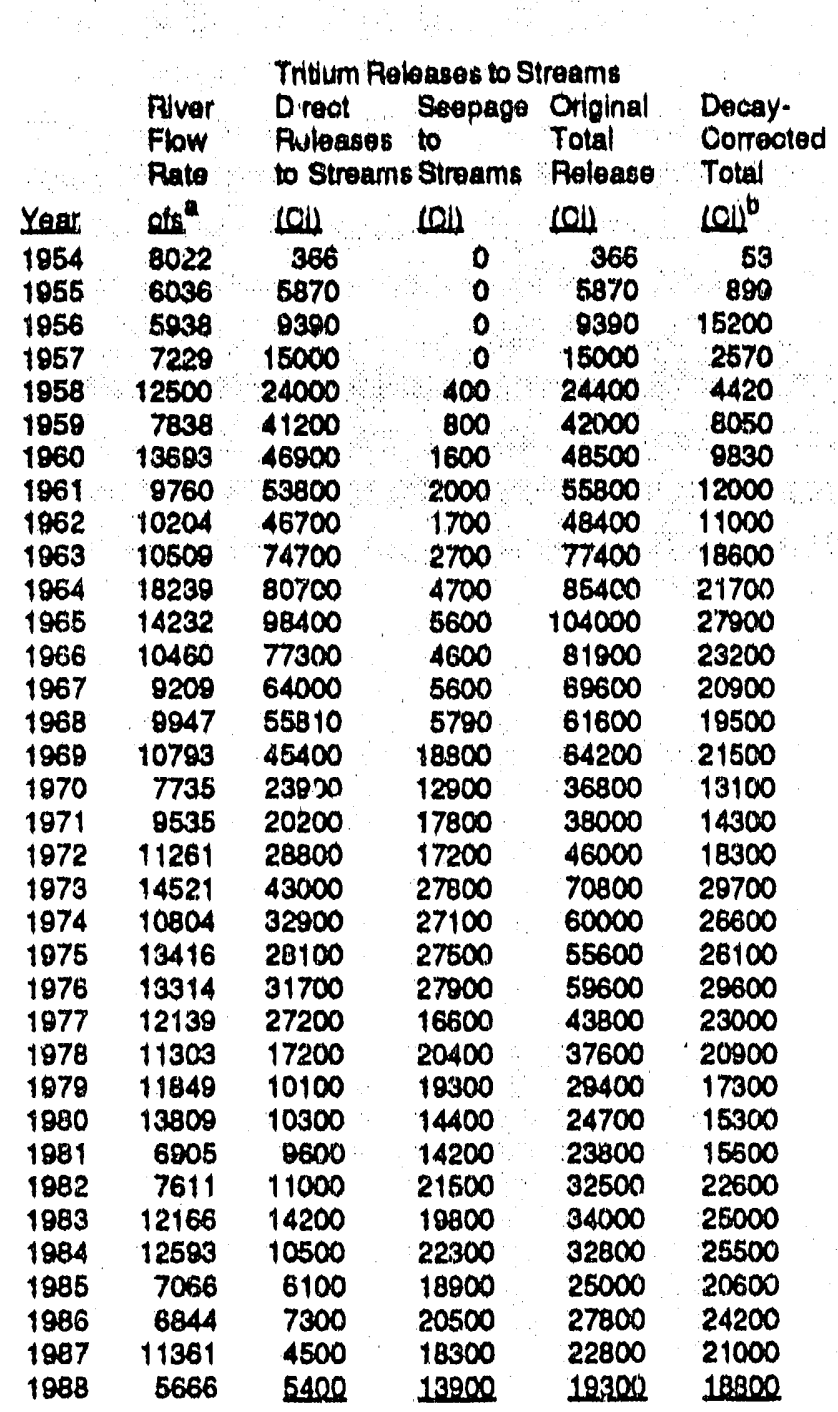

\author{
SRS 100-Mile 100-Mile \\ Maximum Maximum Average
}

Downstrm Downstrm Downstrm BN H2O PW H2O SA Flah

Indlvidual Individual Indlvidual Users Users Consumers

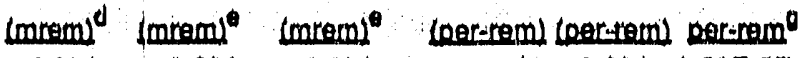

$\begin{array}{llllll}0.001 & 0.002 & 0.001 & 0.024 & 0.39 E-07\end{array}$

$\begin{array}{llllll}0.027 & 0.050 & 0.025 & 0.024 & 0.307 & 0.23 E-06\end{array}$

$\begin{array}{llllll}0.045 & 0.081 & 0.041 & \text { I } & 0.825 & 1.17 E-05\end{array}$

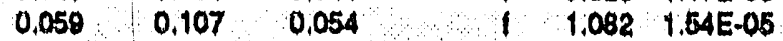

$\begin{array}{lllll}0.055 & 0.101 & 0.051 & 1.018 & 1.45 E-05\end{array}$

$\begin{array}{llllll}0.152 & 0.276 & 0.140 & 1 & 2.795 & 3.08 E-05\end{array}$

$\begin{array}{llllll}0.100 & 0.182 & 0.092 & 0.864 \quad 2.63 E-05\end{array}$

$\begin{array}{llllll}0.162 & 0.294 & 0.149 & 2.882 & 4.25 \mathrm{E}-05\end{array}$

$\begin{array}{llllll}0.134 & 0.244 & 0.124 & 2.474 & 3.52 E-05\end{array}$

$\begin{array}{llllll}0.208 & 0.379 & 0.192 & 0.474 & 3.42 E-05 \\ & 0.341 & 0.122 & 0.842 & 5.47 E-05\end{array}$

$\begin{array}{lllll}0.132 & 0.241 & 0.122 & 0.443 & 3.48 E-05\end{array}$

$\begin{array}{lllllll}0.207 & 0.376 & 0.191 & 8.830 & 3.812 & 5.43 E-05\end{array}$

$\begin{array}{llllll}0.221 & 0.403 & 0.204 & 9.460 & 4.084 & 8.82 E-05\end{array}$

$\begin{array}{llllll}0.214 & 0.389 & 0.197 & 9.130 & 3.943 & 5.62 \mathrm{E}-05\end{array}$

$\begin{array}{lllllll}0.175 & 0.319 & 0.162 & 7.480 & 3.230 & 4.60 E-05\end{array}$

$\begin{array}{lllllll}0.168 & 0.306 & 0.155 & 7.180 & 3.103 & 4.42 E-05\end{array}$

$\begin{array}{llllll}0.135 & 0.245 & 0.124 & 5.743 & 2.482 & 3.53 E-05\end{array}$

$\begin{array}{lllllll}0.113 & 0.205 & 0.104 & 4.811 & 2.079 & 2.86 E-05\end{array}$

$\begin{array}{llllll}0.115 & 0.210 & 0.107 & 4.231 & 2.131 & 3.04 E-05\end{array}$

$\begin{array}{llllllll}0.138 & 0.251 & 0.127 & 5.885 & 2.543 & 3.62 E-05\end{array}$

$\begin{array}{llllll}0.157 & 0.286 & 0.145 & 6.703 & 2.897 & 4.10 E-05\end{array}$

$\begin{array}{llllll}0.117 & 0.213 & 0.108 & 6.002 & 2.162 & 3.08 E-05\end{array}$

$\begin{array}{lllllll}0.127 & 0.231 & 0.117 & 5.403 & 2.335 & 3.33 E-05\end{array}$

$\begin{array}{llllll}0.102 & 0.186 & 0.094 & 4.355 & 1.882 & 2.68 E-05\end{array}$

$\begin{array}{llllll}0.094 & 0.171 & 0.087 & 4.015 & 1.735 & 2.47 E-05\end{array}$

$\begin{array}{llllll}0.070 & 0.128 & 0.065 & 2.995 & 1.294 & 1.84 E-05\end{array}$

$\begin{array}{lllllll}0.051 & 0.092 & 0.047 & 2.159 & 0.933 & 1.33 E-05\end{array}$

$\begin{array}{lllllll}0.097 & 0.178 & 0.090 & 4.150 & 1.798 & 2.56 \mathrm{E}-05\end{array}$

$\begin{array}{lllllll}0.121 & 0.220 & 0.111 & 5.154 & 2.228 & 3.17 E-0.5\end{array}$

$\begin{array}{lllllll}0.079 & 0.144 & 0.073 & 3.373 & 1.458 & 2.08 E-05\end{array}$

$\begin{array}{lllllll}0.074 & 0.134 & 0.068 & 3.144 & 1.359 & 1.04 E-05\end{array}$

$\begin{array}{llllllll}0.100 & 0.182 & 0.092 & 4.271 & 1.846 & 2.60 E-05\end{array}$

$\begin{array}{lllllll}0.115 & 0.209 & 0.106 & 4.003 & 2.119 & 3.02 E-05\end{array}$

$\begin{array}{llllll}0.057 & 0.103 & 0.052 & 2.422 & 1.047 & 1.49 E-05\end{array}$

$0.096 \quad 0.175 \quad 0.089 \quad 4.112 \quad 1777$ 2.53E-05

TOTALS

Notes:

$$
1,081,536 \quad 432,590 \quad 1,514,126 \quad 624,769
$$

7.3
3.7

126
$74 \quad 0.001$

- Flow rate data for downstream dose calculations based on USGS moasurements at Augusta, GA (1953 - 1972) and the SAS boat dock $(1973-1988)+10 \%$.

b Annual releases have been decay-corrected to $-01-01-89$ to show remaining litilum inventory. Doses are based on undecayed activity.

- Values presented are effective dose equivalents (EDEs).

- Evaluatod at a location just downstream of SRS.

- A water consumer at the Boaufort-Jasper (B) or Port Wentworth (PW) water iteratment plant.

1 The Beaufort-Jasper water treatment plant did not start operation undil Januaiy 1965.

- Fish dose indudes both the consumption of commercial and sports harvests of freshwater fish from downstream of the SRS as well as the consumption of shellfish harvested from estuaries of the Savannah Rlver. 
Although tritium is the primary contributor to offsite doses from SRS operations, it is an essentially insignificant component of an average Individual's total annual dose equiv* alent. Based on 1988 data, the "maximum" Individual living at the site's border received doses of 0.30 and 0.10 mrem from atmospheric and liquid tritium releases, respectively. This hypothetical individual's total dose from natural sources for 1988 was approximately $300 \mathrm{mrem}$ (Du Pont 1988). Therefore, the contribution of SRS to the individual's radiation exposure in 1988 was about $0.14 \%$.

When examined on a population basis, the total cumulative dose attributable to atmospheric and liquid tritlum releases from the SRS during 35 years of operation was 1500 person-rem distributed among 626,150 people. Use of the EPA nominal risk estimate suggests that 0.60 excess fatal cancers may be assoclated with this collective dose. Within a population of 626,150 people, approximately 105,000 will ultimately die from all types of cancer. Therefore, it is unlikely that a relationship between any of the cancer deaths occurring in this population and the releases of tritlum from the SRS will be encountered. 
INTRODUCTION

An average member of the public receives an annual dose of about 300 mrem from natural sources of radiation in the vicinity of the SRS (WSRC 19890). Based on national averages, this is about $80 \%$ of the total radiation dose received annually by a member of the public from all sources. Medical exposures account for about $15 \%$ of the annual dose, and the combined doses from nuclear facillties (other than SRS), consumer products, weapons test fallout, and miscellaneous other sources account for about $4 \%$ of the dose. Releases of radioactivity to the environment from the SRS account for about $0.01 \%$ of the total environmental radiation dose in the vicinity of SRS.

Three general sources of radiation exposure for persons in the United States are briefly discussed in the following sections. The three sources are (1) radiation of natural origin, unperturbed by human activities, (2) radiation of natural origin, perturbed ky iuman activities, and (3) man-made sources.

\section{NATURAL SOURCES}

Natural sources include cosmic radiation from outer space, cosmogenic radionuclides formed by the interaction of cosmic radiation with elements in the earth's atmosphere, terrestrial radiation from naturally radioactive materials in the ground, radlation from radionuclides naturally in the body, andinhaled and ingested radionuclides of natural origin.

Enhanced natural sources of radiation are of natural origin but enhanced by man's activities. Examples include air travel at high altitudes, with its attendant increase in cosmic radlation; movement of radionuclides in the ground, as in phosphate mining; and removal of radioactive materials from the ground, such as uranium mining which generates a radoncontaining waste product (mill taillings).

Cosmic radiation. Cosmic radiation consists of energetic particles of galactic and solar origin. The radiation of solar origin is assoclated with solar flares, which vary in intensity on an 11-yr cycle. Cosmic dose varies with latitude and altitude above the earth's surface. Sea-level dose rates range from $30 \mathrm{mrem} / \mathrm{yr}$ in Florida to $45 \mathrm{mrem} / \mathrm{yr}$ in Alaska; at an altitude of about $2400 \mathrm{~m}$ the dose rate increases to $200 \mathrm{mrem} / \mathrm{yr}$ (Dukes 1984). An average dose from cosmic radiation in the United States is about $26 \mathrm{mrem} / \mathrm{yr}$. An additional dose increment of $1 \mathrm{mrem} / \mathrm{yr}$ from cosmic radiation is received by an average individual in the United States due to highaltitude air travel.

Cosmic radiation also interacts with materials in the atmosphere and on the surface of the earth to create radioactive nuclides. This source of radiation is called cosmogenic radiation. Many radionuclides are formed by cosmic generation, e.g., tritlum, beryllium-7, carbon-14, sodium-22, and many others. Of these, carbon-14 accounts for most of the dose to man, about $1 \mathrm{mrem} / \mathrm{yr}$.

Primordial radionuclides. Natural radioactive materials that have been present since the earth was formed are called primordlal radionuclides. These materials have very long radioactive half-lives, ranging from hundreds of millions to billions of years. Some of the primordial radionuclides are uranium-235, uranium-238, thorium-232, rubidium-87, and potassium-40. Variations in the distributions of these naturally occurring radionuclides in geologic formations lead to wide variations in dose rates with location. The average unchielded external dose rate 
trom this source is approximately $60 \mathrm{mrem} / \mathrm{yr}$ in Georgla and $70 \mathrm{mrem} / \mathrm{yr}$ in South Carolina. However, the variation in these states (Including the SRS area) ranges from 6 to more than $350 \mathrm{mrem} / \mathrm{yr}$. An average dose in the United States, corrected for shielding effects, is $28 \mathrm{mrem} / \mathrm{yr}$.

Primordial radionuclides and their radioactive daughter products enter the human body in food, air, and water. An average person receives a radiation dose of about 39 $\mathrm{mrem} / \mathrm{yr}$ from these natural radioactive materials in the body. Potassium-40, because of the large amount of potassium in the body (about 140 grams), accounts for about $50 \%$ oi this internal dose.

Radioactive decay products of primordial radionuclides can enter the atmosphere as gases or by resuspension of particles. Such movement can lead to radiation exposure by inhalation. Radon-222, a decay product of natural uranium (U-238), has been found to be the largest single source of radiation exposure to man. Radon emanating from the earth is present in the atmosphere we breathe, and is frequently trapped in significant concentrations in structures. It has been determined that an average individual in the United States receives a dose of $200 \mathrm{mrem} / \mathrm{yr}$ from radon and its daughter products. This Inhalation dose accounts for about $55 \%$ of the average annual radiation dose in the United States.

\section{MAN-MADE SOURCES}

Man-made sources result from exposures to radiopharmaceuticals and $X$-rays in medicine, consumer products such as smoke detectors and static eliminators, and $X$ rays from television receivers.
Medical exposures. Medical radiation is the largest source of man-made radiation exposure in the United States. The average dose to an individual from medical and dental $X$ rays, prorated over the entire population, is $39 \mathrm{mrem} / \mathrm{yr}$ (NCRP 1987b). In addition, radiopharmaceuticals administered for diagnostic purposes account for an annual average dose of $14 \mathrm{mrem} / \mathrm{yr}$ when prorated overthe population. Thus, the average medical radiation dose in the United States is about 53 $\mathrm{mrem} / \mathrm{yr}$.

Occupational exposures. Individuals holding positions in flelds such as nuclear medicine or the nuclear industry may be occupationally exposed to radiation. The annual average dose when prorated over the population is about $0.9 \mathrm{mrem}$.

Nuclear facllity releases. Nuclear facilities release small amounts of radioactive materials to the environment, resulting in minor radiation doses to the public. When averaged over the United States population, this dose amounts to about 0.05 mrem per year.

Other man-made sources. A variety of consumerand industrial products yieldionizing radiation or radioactive materials and therefore result in radiation exposure to the general public. Some of these sources are television sets, luminous dial watches, airport X-ray inspection systems, smoke detectors, tobacco products, fossil fuels, and building materials. The estimated dose for the United States population from these sources is $13 \mathrm{mrem} / \mathrm{yr}$.

There have been no atmospheric nuclear weapons tests since 1980. However, some radioactive materials from prior weapons tests still remain in the environment. The average annual dose to a member of the United States 


\section{SRS Releases Compared to Other Sources of Environmental Radiation}

population from this source is currently about 1 mrem.

Small doses result from miscellaneous radiation sources not previously described. Among these sources are transportation of radioactive materials, the mineral extraction industry, etc. The average annual dose from these sources in the United States is about 0.06 mrem.

\section{RADIATION LEVELS IN THE VICINITY OF THE SRS}

A summary of the major sources of exposure for the population within $80 \mathrm{~km}$ of the SRS and for the river water-consuming populations in Beaufort and Jasper counties in South Carolina and Port Wentworth, GA, is presented in Table 4.1 and illustrated in Figure 4.1. The values are based on population estimates for the year 2000 .

Table 4.2 shows potential health effects from a lifetime of exposure to this environmental radiation on the population groups described above. These health effects were calculated with risk estimators proposed by the Environmental Protection Agency (EPA 1989a). As shown in the table, approximately 190,000 members of the year 2000 population (approximately $16 \%$ of the population) will die from some type of cancer. The radiation environment will account for about $0.05 \%$ (about 91) of these cancer deaths, with natural sources of radiation, the largest source of environmental radiation, accounting for about $81 \%$ (about 74 ) of the cancer deaths.

Many factors, such as the natural background dose and medical dose, are independent of the SRS. The factors that are site-dependent are discussed below.

The SRS and surrounding area lie between latitudes $33^{\circ} \mathrm{N}$ and $34^{\circ} \mathrm{N}$, with an altitude variation between sea level and $300 \mathrm{~m}$ above sea level. It has been estimated that the total unshielded dose equivalent from cosmic

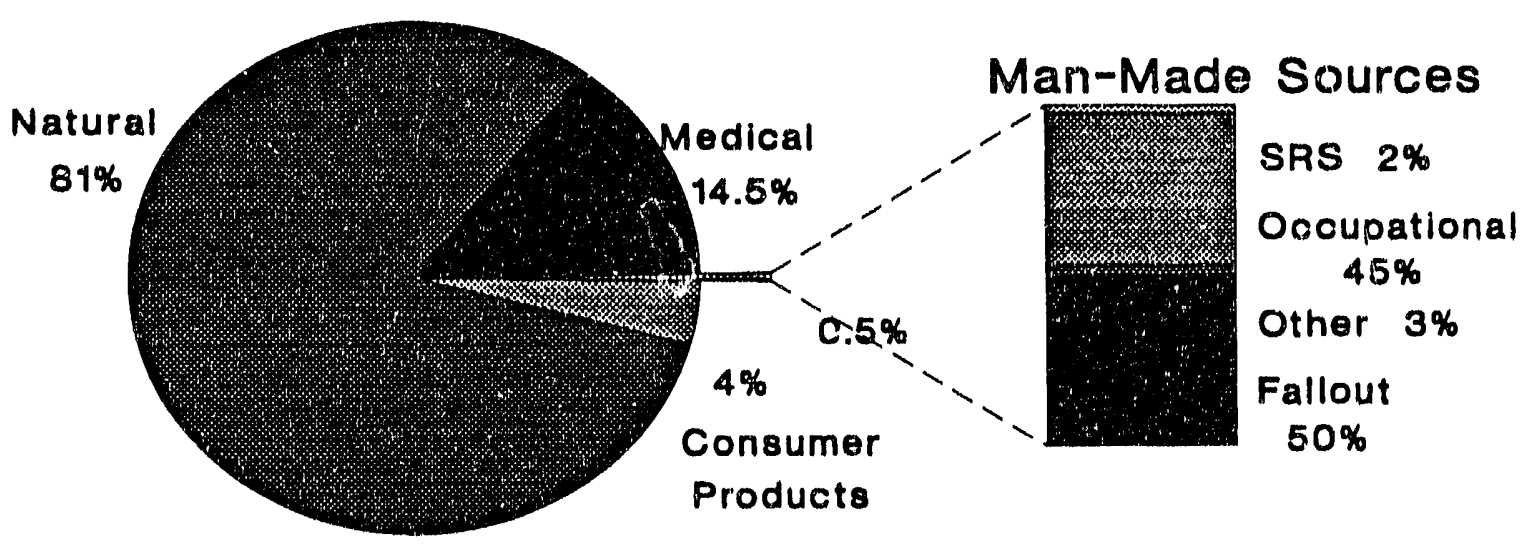

Figure 4.1. The Percentage Contributions to Radiation Exposure for the Population in the SRS Vicinity 
Table 4.1. Major Sources of Radiation Exposure in the Vicinity of SRS.

\begin{tabular}{|c|c|c|c|c|}
\hline Source of Exposure & $\begin{array}{l}\text { Dose to Avg. } \\
\text { Indlvidual } \\
\text { mrem/year }\end{array}$ & $\begin{array}{l}\text { Percent of } \\
\text { Exposure }\end{array}$ & $\begin{array}{l}\text { Population } \\
\text { Dose } \\
\text { person- } \\
\text { rem/year }\end{array}$ & $\begin{array}{l}\text { Fatal } \\
\text { Cancers }\end{array}$ \\
\hline $\begin{array}{l}\text { Natural background radia } \\
\text { Cosmic } \\
\text { Cosmogenic } \\
\text { Terrestrial } \\
\text { Intrled } \\
\text { Present in the body } \\
\text { Total }\end{array}$ & $\begin{array}{r}27 \\
1 \\
28 \\
200 \\
\frac{39}{295^{\circ}}\end{array}$ & $\begin{array}{l}7.44 \\
0.28 \\
7.71 \\
55.09 \\
10.74 \\
81.26\end{array}$ & 184,700 & 74 \\
\hline $\begin{array}{l}\text { Medical radiation } \\
\text { Diagnostic X rays } \\
\text { Nuclear medicine } \\
\text { Total }\end{array}$ & $\begin{array}{l}39 \\
\frac{14}{53^{a}}\end{array}$ & $\begin{array}{r}10.74 \\
3.86 \\
14.60\end{array}$ & 33,183 & 13 \\
\hline Occupational & $0.9^{b}$ & 0.25 & 563 & 0.2 \\
\hline Nuclear facilities & $0.05^{c}$ & 0.01 & 31 & 0.1 \\
\hline Consumer products & $13^{\prime}$ & 3.58 & 8,139 & 3 \\
\hline Weapons test fallout & 1 & 0.28 & 626 & 0.3 \\
\hline $\begin{array}{l}\text { Miscellaneous } \\
\text { SRS atmospheric } \\
\text { radioactivity - average } \\
\text { to } 80-\mathrm{km} \text { radius (1988) }\end{array}$ & $0.06^{\mathrm{a}}$ & 0.02 & 38 & 0.02 \\
\hline Grand Total & 363 & 100 & 227,308 & 91 \\
\hline
\end{tabular}

- Average for U.S. population.

- Average for exposed employees in 1988 (U.S. population). Average for SRS exposed employees was $111 \mathrm{mrem}$ (based on badged employees with dose equivalents $\geq 5 \mathrm{mrem} / \mathrm{yr}$ ).

c Average for population within $80 \mathrm{~km}$ of SRS. 

Radiation

Table 4.2. Potential Fatal Cancers from the Radiation Environment $80-\mathrm{km}$ Radius and Downstream River Water Consumers Year 2000 Population Projections.

Fatal cancers in lifetime - all causes ( $16 \%$ of population)

Fatal cancers per year - all sources of radiation exposure

Radiation cancers as a percent of all cancers

Potential cancers from SRS radiation as a percent of all cancers
190,000

$0.05 \%$

$0.000001 \%$ radiation in the vicinity of the SRS $(80-\mathrm{km}$ radius) is about 35 mrem peryear, of which 29 $\mathrm{mrem} / \mathrm{yr}$ results from directly ionizing radiation and $6 \mathrm{mrem} / \mathrm{yr}$ is attributable to neutrons (Dukes 1984). Shielding by buildings and the body itself reduces the cosmic dose to about $27 \mathrm{mrem} / \mathrm{yr}$ (NCRP 1987b).

\section{SRS STUDY OF TERRESTRIAL DOSE RATES}

An aerial radiological survey of the Savannah River marine region was performed in 1975 to establish terrestrial dose rates (Hayes 1977). These rates varied from 0.001 $\mathrm{mrem} / \mathrm{hr}$ over water to $0.009 \mathrm{mrem} / \mathrm{hr}$ at one location on Wassaw Island, GA. In general, higher rates were found over beaches where heavy minerals containing natural uranium and thorium occur. Excluding the water areas, the terrestrial rate averaged about $0.003 \mathrm{mrem} /$ hr in this area, which is comparable with other coastal plain rates of 0.002 to $0.003 \mathrm{mrem} / \mathrm{hr}$.

The average dose rate for the Savannah River marine area is about the same as that measured in Galveston, TX, and Cape Canaveral, FL, and somewhat less than that in the Los Angeles, CA, area. One anomaly defined in the survey was noted for Hutchinson Island, GA, where dredge soils have been deposited. The cesium-137 concentrations in post-1957 dredgesoil sediments range from about 0.3 to $2.7 \mathrm{pCi} / \mathrm{g}$. About half the cesium137 in the sediment can be attributed to fallout from weapons testing (Marter 1974).
COMPARISONS OF TRITIUM CONCENTRATIONS AND DOSES ON AND NEAR THE SRS WITH APPLICABLE REGULATIONS

\section{Limits on Tritium Concentrations in Air}

Tritium is routinely detected in atmospheric samples collected on and near the SRS. Though the levels are above background, they are well below the limits sanctioned by the International Commission on Radiological Protection (ICRP). Comparisons of tritium concentration in air with the EPA Concentration Guideline, as a function of downwind distance, are shown in Table 4.3. Values are reported exclusively for tritium as water vapor, as it is the more radiotoxic form.

\section{Comparisons with the Drinking Water Standard}

Onsite groundwater. Although groundwater regions impacted by SRS operations are not used as potable water sources, concentrations of tritium in the monitoring wells located onsite are routinely compared to the U.S. EPA drinking water standard. The current standard for tritium in drinking water is $20,000 \mathrm{pCi} / \mathrm{L}(20 \mathrm{pCi} / \mathrm{mL})$. The Environmental Monitoring Section at SRS uses two flagging criteria based on that standard to aid personnel in sampling scheduling, interpretation of data, and trend identification. The more restrictive flagging 
Table 4.3. Ratlos of Average Atmospheric Tritlum (HTO) Concentrations on and Near the SRS $\left(\mathrm{pCl} / \mathrm{m}^{3}\right)$.

\section{Distance from Site Center (km)}

0.10

1.00

10.00

100.00
Calculated

Values:

$3.60 \mathrm{E}+03$

$6.00+02$

$1.00 E+02$

$1.50 \mathrm{E}+01$
Ratio to EPA

Concentration Guide ${ }^{\circ}$

2.40

0.4

0.067

0.01

- Estimated values based on Figure 2.2 of this report.

- The applicable 40 CFR 61 concentration guide for tritium is $1.5 \times 10^{-9} \mathrm{Ci} / \mathrm{m}^{3}$.

level, Level 2, indicates that the tritium concentration in the sample exceeds $20 \mathrm{pCi} / \mathrm{mL}$.

Of the 25 onsite areas found to have Level 2 tritium samples, 18 are associated with separation and waste managementoperations conducted near the center of the SRS (WSRC 1989b). The other groundwater systems known to have tritium concentrations greater than the drinking water standard are those shallow formations impacted by reactor operations. Monitoring well samples in the areas around the reactor seepage and retention basins frequently reflect tritium levels in excess of the EPA standard. Maximum tritium concentrations observed in monitoring wells on the SRS during 1988 are presented in Table 4.4. The values are grouped by facility and reflect the largest concentrations cbserved among all the samples collected from the wells in that area. As shown in the table, many of the values exceed the drinking water standard by several orders of magnitude. It must be stressed that these groundwater systems are not used as potable water sources, and any contaminated water outcropping from them is believed to resurface into onsite streams.
Offslte surface and potable waters. The outcropping of contaminated groundwater and the direct discharge of liquid releases to site streams have raised tritium concentrations in onsite streams to levels above background. Since access to these streams is strictly controlled, the impact to human health is negligible. However, once this tritium leaves the site, the potential for contact with downstream populations exists.

Two water treatment plants downstream of the SRS use Savannah River water for domestic and commercial service. The plants are located approximately $160 \mathrm{~km}$ below the SRS. The raw and finished drinking water supplies of the Beaufort-Jasper, SC, and Port Wentworth, GA, plants are routinely sampled for tritium content. Table 4.5 shows the tritium concentrations at those sites in 1988 and compares them to the EPA drinking water standard. Comparisons of tritium concentrations with the drinking water standard are more meaningful in this case because these data are based on samples collected from public water supplies. As shown in the table, the tritium concentrations at the plants are in the range of $10 \%$ to $15 \%$ of the drinking water standard. Table 4.5 also 
Table 4.4. Maximum Tritium Concentrations in Selected SRS Wells (pCl/mL).

Separatlons Faclittles

Reactor Facillties

$\begin{array}{lcc}\text { Burlal Grounds } & \begin{array}{c}\text { Measured } \\ \text { Yalues }\end{array} & \begin{array}{c}\text { Ratlo to } \\ \text { DWS }^{\text {b }}\end{array} \\ \text { Area Perimeter } & 2.92 E+06 & 146000 \\ \text { 643-G (Center) } & 1.84 E+06 & 92000 \\ 643-G \text { (Center) } & 2.81 E+06 & 140500 \\ \text { 643-G (South) } & 3.48 E+06 & 174000\end{array}$

C Area

Measured

Coal Pile

Runoff Basin

Yalues"

Ratlo to

Disassembly

Basin

$1.08 \mathrm{E}+01$

DWS $^{\mathbf{b}}$

Buming/Rubble Pi

$4.33 E+02$

0.54

Seepage Basins

2.59E+02

21.65

8.61E+02

12.95

43.05

\section{F Area}

K Aroa

Seepage Basins

$6.58 E+04$

3290

$4.52 E+02 \quad 22.6$

Tank Farm

$2.57 E+02$

12.85

Acid/Caustic Basin

$9.80 E+00$

0.49

Disassembly Basin

$2.43 E+03$

Retertion Basin

$1.36 \mathrm{E}+05$

Seepage Basin

3.27E+02

121.5

6800

16.35

H Area

L Area

Seepage Basins

$9.80 E+04 \quad 4900$

Canyon Bldg

$1.40 E+02$

7

7.21E+02 $\quad 36.05$

Acid/Caustic Basin

1. $68 \mathrm{E}+01$

0.84

Disassembly Basin

ID (C)

Burning/Rubble Pit

ID (c)

Seepage Basin

$3.19 E+03$

159.5

$S$ Background

2.27E+01

1.135

Z Background

$1.40 E+01$

P Area

Acid/Caustic Basin

1.34E+01

0.67

Disassembly Basin

4.98E+02

24.9

Buming/Rubble Pit

$3.76 E+01$

1.88

Seepage Basin

2.67E+05

13350

Tech/Raw Materlals Facllitles

$\begin{array}{lll}\text { A and M Areas } & \begin{array}{l}\text { Measured } \\ \text { Values (a) }\end{array} & \begin{array}{l}\text { Ratlo to } \\ \text { DWS (b) }\end{array} \\ \begin{array}{l}\text { Metals Burning Pit } \\ \text { SRL Seepage } \\ \text { Basins }\end{array} & 2.49 E+01 & 1.245 \\ \begin{array}{l}\text { Misc. Chem Basin } \\ \begin{array}{l}\text { M-Area Settling } \\ \text { Basin }\end{array}\end{array} & 2.40 E+00 & 0.12 \\ & 2.91 E+00 & 0.1455\end{array}$

- Measured values are based on data presented in the 1988 SRS Environmental Report.

b U.S. EPA drinking water standard for tritium $=20 \mathrm{pCi} / \mathrm{mL}$.

- ID indicales insutficient data ( $n<5)$. 
Table 4.5. Tritlum Concentrations In Offsite Surface and Potable Waters.

\begin{tabular}{|c|c|c|c|}
\hline Location & $\begin{array}{l}\text { Measured } \\
\text { Valuesa } \\
\mathrm{pCl} / \mathrm{mL}\end{array}$ & $\begin{array}{l}\text { Ratlo to } \\
\text { DOE DCG }\end{array}$ & $\begin{array}{l}\text { Ratio to } \\
\text { DWS }\end{array}$ \\
\hline avannah River just downstream of the SRS & $3.40 E+00$ & $1.70 E-03$ & $1.70 \mathrm{E}-01$ \\
\hline eaufort-Jasper drinking water & $2.60 E+00$ & $1.30 E-03$ & $1.30 \mathrm{E}-01$ \\
\hline It Wentworth drinking water & $2.50 E+00$ & $1.30 \mathrm{E}-03$ & $1.25 E-01$ \\
\hline Edisto River & $3.30 E-01$ & $2.00 E-04$ & $170 \mathrm{E}-02$ \\
\hline
\end{tabular}

confirms that the tritium concentrations just downstream of the SRS are well below (by a factor of 600) the concentration guideline established by the DOE for tritium in surface water discharges.

\section{RADIATION PROTECTION GUIDELINES}

Atmospheric releases. An examination of the dose calculations previously reported in this document shows that the highest hypothetical dose received by a maximally exposed individual from atmospheric releases of tritium from SRS was 2.48 mrem in 1958. The current annual limits on doses to members of the public recommended by the ICRP and the DOE are 500 and $100 \mathrm{mrem}$, respectively. It is noteworthy that neither the worst-case annual dose nor the worst-case cumulative dose reported in Table 3.6 exceeded or approached these annual limits. The worst- case annual dose was only $25 \%$ of the current annual EPA exposure limit of $10 \mathrm{mrem}$ (10 CFR 61).

Liquid releases. The figure-of-merit for evaluating doses from drinking water sources is the current EPA drinking water standard of $20 \mathrm{pCi} / \mathrm{mL}$. The $20 \mathrm{pCi} / \mathrm{mL}$ limit is designed to ensure that doses to individuals from tritium in public drinking water supplies do not exceed $4 \mathrm{mrem} / \mathrm{yr}$ (effective dose equivalent). The EPA is considering new regulations incorporating ICRP 30 methodology which may increase the drinking water standard for tritium to $90 \mathrm{pCi} / \mathrm{mL}$ (EPA 1986). However, all comparisons presented in this report have been based on the $20 \mathrm{pCi} / \mathrm{mL}$ standard.

As shown in Table 3.7, at no time during site operations has a dose from SRS tritium releases to the Savannah River exceeded 1 


\section{SRS Releases Compared to Other Sources of Environmental}

\section{Radiation}

mrem. Doses from this exposure pathway were caiculated under extremely conservative conditions and are without exception much lower than the DOE operational guide and the EPA drinking water standard.

It is important to note that all of the dose limits described above are meant to be applied to all releases of radloactivity - not just tritlum. When the calculations are expanded to include all radionuolide releases, the relationship between SRS toses and the various dose limits described above remains valid. Based on tritium or total releases, the SRS is consistently a minor contributor to radioactivity levels in the offsite environment. (More information on the roles of other radionuclides in SRS releases and doses can be found in the annual environmental reports.) 
128

Tritlum in the Savannah River Site Environment 
Addls, R.P. 1988. Savannah River Plant Emergency Response: Environmental Trans" port and Assessment, DP-MS-88-166, Savannah River Laboratory, Alken, SC.

Anspaugh, L. R., J. J. Koranda, W. L. Roblson, and J. R. Martin. 1973. "The Dose to Man Vla Food-Chain Transfer Resulting from Exposure to Tritlated Water Vapor," pp. 405422 In Tritium, (eds. A. A. Moghissl and M. W. Carter), Messenger Graphics, Phoenlx, AZ.

Atkinson, L.P., J.O. Blanton, and Evelyn B. Haines. 1978. "Shelf Flushing Rates Based on the Distribution of Salinity and Freshwater in the Georgla Bight," Estuarine and Coastal Marine Science 7:465-472.

Belot, Y., D. Ganthier, H. Camus, and C. Caput. 1979. "Prediction of the Flux of Tritlated Water from the Alr to Plant Leaves," Health Phys. 37, 575-583.

Belot, Y., J. Guenot, C. Caput, and F. Bourdeau. 1983. "Incorporation of Tritium into Organic Matter of Terrestrial Plants Exposed to Tritiated-Water Releases of Short Duration," Health Physics 44:666-668.

Belot, Y., J. Guenot, and C. Caput. 1988. "Emission to Atmosphere of Tritiated Water Formed at Soll Surface by Oxidation of HT," Fusion Technology 14(2):1231-1234.

Chamberlain, A.C. and A.E.J. Eggleton. 1964. "Washout of tritiated water vapour by rain," Int. J. Air Water Polllut. 8:135.

Davis, H.A., D.K. Martin, and J.L. Todd. 1989. Savannah River Site Environmental Report For 1988. WSRC-RP-89-59-1, Westinghouse Savannah River Company, Savannah River Site, Aiken, SC 29808.
DOE (U.S. Department of Energy). 1984. L. Reactor Operation, Savannah River Plant Final Environmental Impact Statement, DOE/ EIS-108, Washington, D.C.

DOE (U.S. Department of Energy). 1988. Internal Dose Conversion Factors for Caloulation of Dose to the Public, DOE/EH-0070, Washington, D.C.

Du Pont (E.I. du Pont de Nemours \& Co.). 1983a. Works Technical Monthly Progress Report, DPSP 83-1-4, Savannah River Plant, Alken, SC.

Du Pont (E.I. du Pont de Nemours \& Co.). 1983b. Works Technical Monthly Progress Report, DPSP 83-1-5, Savannah River Plant, Alken, SC.

Du Pont (E.I. du Pont de Nemours \& Co.). 1984. Works Technical Monthly Progress Report, DPSP 84-1-5, Savannah River Plant, Alken, SC.

Du Pont. 1986. DPSPU-86-21-1, E. I. du Pont de Nemours \& Co., Savannah River Laboratory, Aiken, SC.

Du Pont (E.I. du Pont de Nemours \& Co.). 1908. Savannah River Plant Environmental Report for 1987, DPSPU-88-30-1, Vol. 2, Alken, SC.

Dukes, E.K. 1984. The Savannah River Plant Environment, DP-1642, Savannah River Laboratory, Aiken, SC.

Dunstall, T. G., G. L. Ogram, and F. S. Spencer. 1985. "Elemental Tritlum Deposition and Conversion in the Terrestrial Environment," Fusion Technology 8(2), 2551-2556. 
Dyer, K.R. 1973. Estuaries: A Physical Introduction. J. Wiley \& Sons, New York.

Eckerman, K.F., F.J. Congel, A.K. Roecklein, and W.J. Pasclak. 1980. User's Guide to GASPAR Code, NUREG-0597, U.S. Nuclear Regulatory Commission, Washington, D.C.

EIA. December 1988. Monthly Energy Re. View, Energy Information Administration, DOE/ EIA-0035(88/12), pp. 128-129.

EPA 1986. 40 CFR Part 141." Water Pollution Control; National Primary Drinking Water Regulations; Radionuclides; Advance Notice of Proposed Rulemaking," Federal Register Vol. 51, No. 189.

EPA (U.S. Environmental Protection Agency). 1989a. Draft Environmental Impact Statement for Proposed NESHAPS for Radionuclides - Risk Assessment Methodology, Volume 1, EPA 520/1-89-005, Washington, D.C.

EPA (U.S. Environmental Protection Agency). 1989b. 40 CFR Part 61, "National Emission Standards for Hazardous Air Pollutants; Regulation of Radionuclides; Proposed Rule and Notice of Public Hearing, " Federal Register, Vol. 54, No. 43.

Evans, A. G. 1969. "New Dose Estimates from Chronic Tritium Exposures," Health Phys. 16(1):57-63.

Fallon, R. D. 1982a. "Influences of pH, Temperature, and Moisture on Gaseous Tritium Uptake in Surface Solls," Appl. Envir. Microbiology 44(1):171-178.

Fallon, R. D. 1982b. "Molecular Tritium Uptake in Southeastern U. S. Soils," Soil Biol. Biochem. 14:553-556.
Foerstel, H., K. Lepa, and $H$. Trierweller. 1988. "Re-emission of HTO Into the Atmosphere After HT/HTO Conversion in the Soll," Fusion Technology 14(2):1203-1208.

Garland, J. A. and L. C. Cox. 1980. "The Absorption of Tritlum Gas by English Solls and Plants and the Sea Water," Air and Soil Pollution 14:103-114.

Garland, J.A. and L.C. Cox. 1982. "Uptake of Tritiated Water Vapour by Bean Leaves," Air and Soll Pollution 17: 207.

Guenot, J.A. and Y. Belot. 1984. "Assimilation of "H in Photosynthesizing Leaves," Health Physics 47:849-855.

Harrison, J.E. Internal Memorandum, J.E. Harrison to File, Tritlum Atmospheric Releases from Waste Tank Exhausts, Savannah River Plant, Aiken, SC, March 22, 1983.

Hayes, D.W. 1977. "Aerial Radiological Survey of the Savannah River Marine Region, "in Savannah River Laboratory Environmental Transport and Effects Research (compiled by T.V. Crawford), DP-1455, Savannah River Laboratory, Aiken, SC.

Hayes, D.W. 1979. "Tritium in the Savannah River Estuary and adjacent marine waters," in: Behavior of Tritium in the Environment, IAEA STI/PUB/498, pp. 271-289, IAEA.

Hayes, D.W. 1982. "Design and Evaluation of a Freeze-Dry Apparatus for Removing Water for Tritium Analysis," DP-1634, 20 pp. SRL, E.I. du Pont de Nemours \& Co., Alken, S.C.

Hayes, D. W. 1983. "Examples of SR Water Dilution between the SRP and the BeaufortJasper and PW Water Treatment Plants," DPST-82-1076, SRL, E.I. du Pont de Nemours \& Co., Aiken, S.C. 
ICRP (International Commission on Radlological Protection). 1974. "Report of a Task Group on Reference Man," ICRP Publication 23. Annals of the ICRP.

ICRP (International Commission on Radiological Protection). 1978. "Limits for Intake of Radionuclides by Workers," ICRP Publication 30, Annals of the ICRP.

Jaegge, W. J., N. L. Kolb, B. B. Looney, I. W. Marine, O. A. Towler, and J. R. Cook. 1987. Environmental Information Document: Radioactive Waste Burlal Grounds, DPST-85. 694, E. I. du Pont de Nemours \& Co., Savannah Rlver Laboratory, Alken, SC.

Langley, T.M. and W.L. Marter, 1973. The Savannah River Plant Site. DP-1323, E.I. du Pont de Nemours \& Co., Alken, SC, p. 175.

Marter, W. L. 1974. Environmental Effects of a Tritium Gas Release from the Savannah River Plant on May 2, 1974, DP-1369, E. I. du Pont de Nemours \& Co., Savannah River Plant, Alken, SC.

Marter, W.L. 1974. Radioactivity from SRP Operations in a Downstream Savannah River Swamp, DP-1370, Savannah River Laboratory, Aiken, SC.

Marter, W.L. 1984. Environmental Dosimetry for Normal Operations at SRP, DPST-83270, Rev. 1, Savannah River Laboratory, Aiken, SC.

McFarlane, J. C., R. D. Rogers, and D. V. Bradley. 1978, "Environmental Tritlum Oxidation In Surface Soll," Env. Sci. Technol, 590 593.

McFarlane, J.C., R.D. Rogers, and D.V. Bradley, Jr. 1980. "Elemerital Tritium Analysis by Bio-oxidation," Health Phys. 38, 345.
Moses, V. and M. Calvin. 1959, "Photosynthesis Studies with Tritlated Water," Blochimica et Blophysica Acta 33, 297-312.

Murphy, C. E., Jr. 1984. "The Relationshlp Between Tritlated Water Activitles in Alr, Vegetation, and Soll Under Steady-State Conditions," Healith Phys. 47(4), 635-639.

Murphy, C.E., Jr. A. L. Bonl, and S. P. Tucker. 1976. The Conversion of Gaseous Molecular Tritium to Tritiated Water in Biological Systems, DP-1422, E. I. du Pont de Nemours \& Co., Savannah River Laboratory, Alken, SC.

Murphy, C. E., Jr. and M. M. Pendergast. 1979. "Environmental Transport and Cycling of Tritlum in the Vicinity of Atmospherlc Releases," Behavior of Tritium in the Environment, IAEA, Vienna, pp. 361-372.

NAS (National Academy of Sciences). 1980. The Effects on Populations of Exposure to Low Levels of lonizing Radiation.

NCRP (National Council on Radiation Protection). 1979a. Tritium in the Environment, NCRP Report No. 62, Washington, D.C.

NCRP (National Council on Radiation Protection). 1979b. Tritium and Other Compounds Incorporated in Genetic Material, NCRP Report No. 63, Washington, D.C.

NCRP (National Council on Radiation Protection). 1987a. Recommendations on Limits for Ionizing Radiation Exposure, NCRP Report No. 91 , Washington, D.C.

NCRP (Natlonal Council on Radiatlon Protection and Measurements). 1987b. lonizing Radiation Exposure of the Population of the United States, NCRP Report No. 93, Washington, D.C. 
NCRP (National Counoll on Radiation Proteotion and Measurements). 1987c. Public Ra. diation Exposure from Nuclear Power Generation in the United States. NCRP Report Number 92, Washington, D.C.

NRC (U.S. Nuclear Regulatory Commission). 1977a. "Methods for Estimating Atmospherlo Transport and Dispersion of Gaseous Effluents in Routine Releases from Light-WaterCooled Reactors," Regulatory Guide 1.111, Rev. 1, Washington, D.C.

NRC (U.S. Nuclear Regulatory Commission). 1977b. "Caloulation of Annual Doses to Man from Routine Releases of Reactor Effluents for the Purpose of Evaluating Compliance with 10 CFR Part 50," Appendix I, Regulatory Guide 1.109, Rev. 1, Washington, D.C.

Pasquill, F. 1968. Atmospheric Diffusion. D. van Nostrand Company Ltd. London, 297 pp.

Raney, F. and Y. Vaadia. 1965. "Movement and Disiribution of THO in Tissue Water and Vapor Transpired by Shoots of Hellanthus and Nicotlana Plant," Phys. 40:383-388.

Sagendori, J.F. and J.T. Goll. 1977. XOQDOQ Program for Meteorological Evaluation of Routine Effluent Releases at Nuclear Power Stations, NUREQ-0324, Washington, D.C.

Sanders, S. M. 1976. Non-labile Tritium in Savannah River Plant Pine Trees, DP-1407, E. I. du Pont de Nemours \& Co., Savannah River Laboratory, Alken, SC.

Sigg, R.A. 1984. A Mobile Laboratory for Near Real-Time Measurements of Very LowLevel Radioactivity, DP-MS-84-88, Savannah River Laboratory, Alken, SC.
SImpson, D.B. and B.L. MoGIll, 1980. Users Manual for LADTAP II - A Computer Program for Calculating Radlation Exposure to Man from Routine Releases of Nuclear Reactor Effluents, NUREG/CR-1276, ORNL/TDMC. 1, Oak Ridge Natlonal Laboratory, Oak Rilge, TN.

Slade, D.H. 1968. Meteorology and Atomic Energy. USAEC, TID-24190, Clearinghouse for Federal Solentiflo and Technical Informa. tion, Springfleld, VA.

Sweet, C. W. and C. E. Murphy, Jr. 1981. "Oxidation of Molecular Tritium by Intact Solls," Environmental Science \& Technology 15:1485-1487.

Sweet, C. W. and C. E. Murphy, Jr. 1984. "Tritlum Deposition in Pines and Soll from Atmospheric Releases of Molecular Tritlum," Envirn. Sci. Tech. 18:358-361.

Sweet, C. W., C. E. Murphy, Jr., and R. Lorenz. 1983. "Environmental Tritlum Transport from an Atmospheric Release of Tritlated Water," Health Phys. 44(1), 13-18.

UNSCEAR (United Natlons Scientific Cornmittee on the Effects of Atomic Radiation). 1982. Ionizing Radiation Sources and Biological Effects., New York, NY.

van den Hook, J.,R. Kirchman, and N.B. Juan. 1979. "Transferand Incoporation of Tritium in Marnmals," in Behavior of Tritium in the Environment, IAEA, Vienna.

Wiener, B., M. Taschner, and C. Bunnenberg. 1988. "HTO Reemission from Soll after HT Deposition and Dose Consequences of HT Releases," Fusion Technology 14(2):12471252. 
WSRC (Westlinghouse Savannah River Company). 1989a. Savannah, River Site, Environmental Report for 1988, WSRC-RP-89-59-1, Savannah Rlver Slte, Alken, SC.

WSRC (Westinghouse Savannah Rlver Company). 1989b. The Savannah River Site's Groundwater Monitoring Program - Fourth Quarter 1988, HPR-89-193, Savannah Rlver Site, Alken, SC.

WSRC (Westinghouse Savannah River Company). 1989c. Savannah River Site Environmental Implementation Plan, WSRC-RP. 89-453, Savannah River Slte, Alken, SC.

Zlegler,C.C. and I.B. Lawrimore. 1988, Releases of Radioactivity at the Savannah River Plant, DPSPU-86-25-1, Revised 6/1/88, E.I. du Pont de Nemours \& Co., Savannah River Laboratory, Alken, SC. 


\section{INTRODUCTION}

Tritium releases have been monitored at SRS since the beginning of tritlum production. Measurement systems have been expanded and upgraded as the technology of tritlum measurement evolved. An example of this is the routine measurement of tritlum chemical forms in the separations areas stacks. Initial experimental measurements were made in the late 1970 s and the present operational system was installed in 1985.

The measurement of tritlum in the environment away from the production areas was sporadic in the early days of production because of the difflculty in measuring tritil $m$ at the concentrations which normally occur in the SRS environment with the techniques available at that time. In addition, the emphasis was on measurement of other nuclides that were known to be more radiotoxic. Environmental monitoring of tritium concentrations increased as better measurement techniques became avallable and the priority for tritium measurements increased.

Tritium measurements of milk samples were made as early as 1959 . The measurement of stream water samples began in 1960 . While these measurement were sufficient to guard against larger than ordinary releases, they could not detect the concentrations normally found in environmental samples near SRS. Measurement techniques improved continuously until around 1970, when the full use of liquid scintillation counting allowed routine measurement of most samples in the range of tritium concentrations found in the SRS environment.

The measurement of atmospheric tritiated water vapor at a number of standard sampling locations became routine in 1963 . Tritium in rainfall was routinely measured at a network of rain gages after 1970. Tritlum in vegetation water was added in 1974.

Tritlum in selected deer and hogs killed in controlled hunts have also been moritored. The following section briefly describes the tritium effluent and environmental monitoring program at SRS. More detalled accounts can be found in the Annual Environmental Reports (see the Bibllography).

\section{ATMOSPHERIC EFFLUENT MONITORING}

Most atmospheric discharges of tritium are measured by on-line monitoring equipment installed at effluent release points (stacks, in most cases). The majority of the tritlum reloased to the atmosphere has been assoclated with the activities of the tritium production facilities and the reactors.

\section{Reactor Stacks}

The Reactor Department maintains and operates tritium monitoring devices used for both atmospheric losses of moderator as well as the associated tritium releases. The primary tritium monitoring instrument used is the Berthold Tritium Monitor (BTM). The BTM is a gas flow-through proportional counter. The sample exhaust air is mixed with a counting gas before it passes through a 1.3-L proportional counter. The BTM discriminates between tritium and the radioactive noble gases also released from the reactors by using pulse rise time discrimination. The beta particles from tritium have a short range and thus create, through interaction with the counting gas, ion pairs within a limited volume in the counter tube. The noble gases, because of their higher emitted beta energies, create ion pairs within a larger volume in the tube. 


\section{A.2 Tritium in the Savannah River Site Environment}

This allows discrimination of the electrical signals resulting from low- and high-energy beta particles. The signals from the analyzer are interfaced to a computer which converts the signal voltages to radiation units and prints the results.

Another monitor used is the Stack Tritium Monitor (STM), which measures the forms of tritium. The STM consist of two gas flowthrough lonization chambers. An unaltered sample stream of exhaust air flows through one ion chamber, and a dried sample of exhaust alr flows through the other chamber. Silica gel is used to remove tritiated water vapor from the sample exhaust air. The wet chamber measures the tritium oxide, elemental tritlum, and radioactive noble gases. The dried sample measures elemental tritium and radioactive noble gases. The dual chambers are electronically connected so that tholi output is proportional to the difference between the radioactivity measured in each chamber, which provides a measure of the tritiated water vapor exhausted from the stack. Since the majority of releases from the reactor areas are in the form of tritiated water from the heavy water moderator losses, this procedure provides another way of discriminating tritium from the radioactive noble gases.

Athird device which is avallable to measure moderator tritium releases is a dehumidifier on the stack exhaust sample line. Moisture from the stack sample line is "frozen" by the dehumidifier on a continuous basis except for a daily "thawing" for liquid sample collection. The liquid condensate is analyzed for tritium by a laboratory and the tritium loss calculated by employing appropriate air moisture content and stack flow data. This was the principal reactor stack tritium measuring device from startup until 1986, when the advanced type of monitor was installed. This type of monitor also provides a means of checking the results of the other techniques and is a valuable backup when there are problems with the other monitors.

\section{Disassembly Areas}

The fuel and target storage basins (disassembly basins) were designed without any air supply system. The facilities are under a slight positive pressure and an exhaust occurs through doors and other openings in the facilities. The loss of tritium by evaporation from the disassembly basins is determined by drawing a sample of air from over the basin through a sillca gel column. The sample is analyzed and appropriate flow and humidity factors are applied to estimate the tritium discharge.

\section{Modsrator Rework Facility}

Tritium releases from bulldings at the reactor moderator rework facility are determined by continuous dehumidifier sampling, analysis of the condensate collected, and calculation of the releases by applying appropriate air moisture content and stackflow data.

\section{TRITIUM FACILITIES}

Three methods are used to determine tritium releases and/or the forms of tritium released. The primary monitoring system used for stack releases is the Kanne lonization chamber and associated amplifier and strip chart recorder. The system continuously samples, monitors, and records tritium concentration. The stack recorder data and the stack flows are used to calculate the tritium releases. Tritlum forms monitors are installed on the stacks of buildings releasing both tritiated hydrogen and tritlated water 
vapor. These monitors continuously measure and periodically report tritium releases by total tritium, total elemental tritium, and total oxide tritium. Monitoring is accomplished by pulling a sample of gas from the stack. The sample is then separated into two exactly equal streams. One stream is sent directly through a Kanne chamber to measure the total tritium in the gas. The other stream is sent through a drying column assembly, which strips the tritium oxide. The stripped stream is then sent to another Kanne chamber to measure the amount oi elemental tritium in the gas. The amount of tritium oxide is determined by subtraction.

There are four Kanne chambers in each system - the Total Low Range and Total High Range, which measure both forms of tritium, and the Elemental Low Range and Elemental High Range, which measure only the elemental form. The computer receives information from each of the four chambers in the same manner. Each Kanne chamber produces a current proportional to the amount of activity in the gas. The electrical output is interfaced to a computer, which converts the signai to radiation units and records the results.

A Parametrics System I Humidity Analyzer monitors the gas stream before it enters and after it leaves the drying column, in order to determine how well the column removes tritium oxide from the gas. The total of each form of tritium is made available to operations persurinel through the computer monitor and paper piintouts.

The tritium stack monitor integrator is a third system which can be used to measure tritium releases. A sample of the stack gas is sent through an ion chamber, which produces a current proportional to the amount of activity in the gas. This current is then sent to an electrometer. The electrometer measures the current and relays this information to the system's computer. The computer also receives two pressure readings. One reading comes from a transducer that measures the pressure in the ion chamber, and the other comes from a transducer measuring atmospheric pressure. They are used by the computer to calculate the rate at which tritium is being released. The computer uses the current reading and the two pressure readings to perform an integration, using a mathematical model, then updates the totals.

Some facilites use another type of tritium forms sampler to determine the portion of tritium associated with water vapor or hydrogen. The forms samplers continuously collect tritiated water vapor and tritiated hydrogen which has been oxidized to water after drying on molecular sieve collectors. The collectors are removed weekly and analyzed in a laboratory to determine the ratio of elemental to oxide tritium releases. Analysis of activity of the water is by liquid scintillation (described below).

\section{TRITIUM MONITORING IN AQUATIC MEDIA}

The Environmental Monitoring Section collects and analyzes aquatic media to assess the contribution of tritium to the total activity of the environment. There are no in-line tritium liquid effluent monitors at SRS at the present time. All liquid releases are determined by laboratory analysis of effluent samples. Four types of aquatic media are routinely sampled: (1) area effluent outfalls, (2) streams, (3) the Savannah River, and (4) rainwater. The following is a summary of the collection methodology and analysis performed for each type of aquatic media sampled for tritium. 


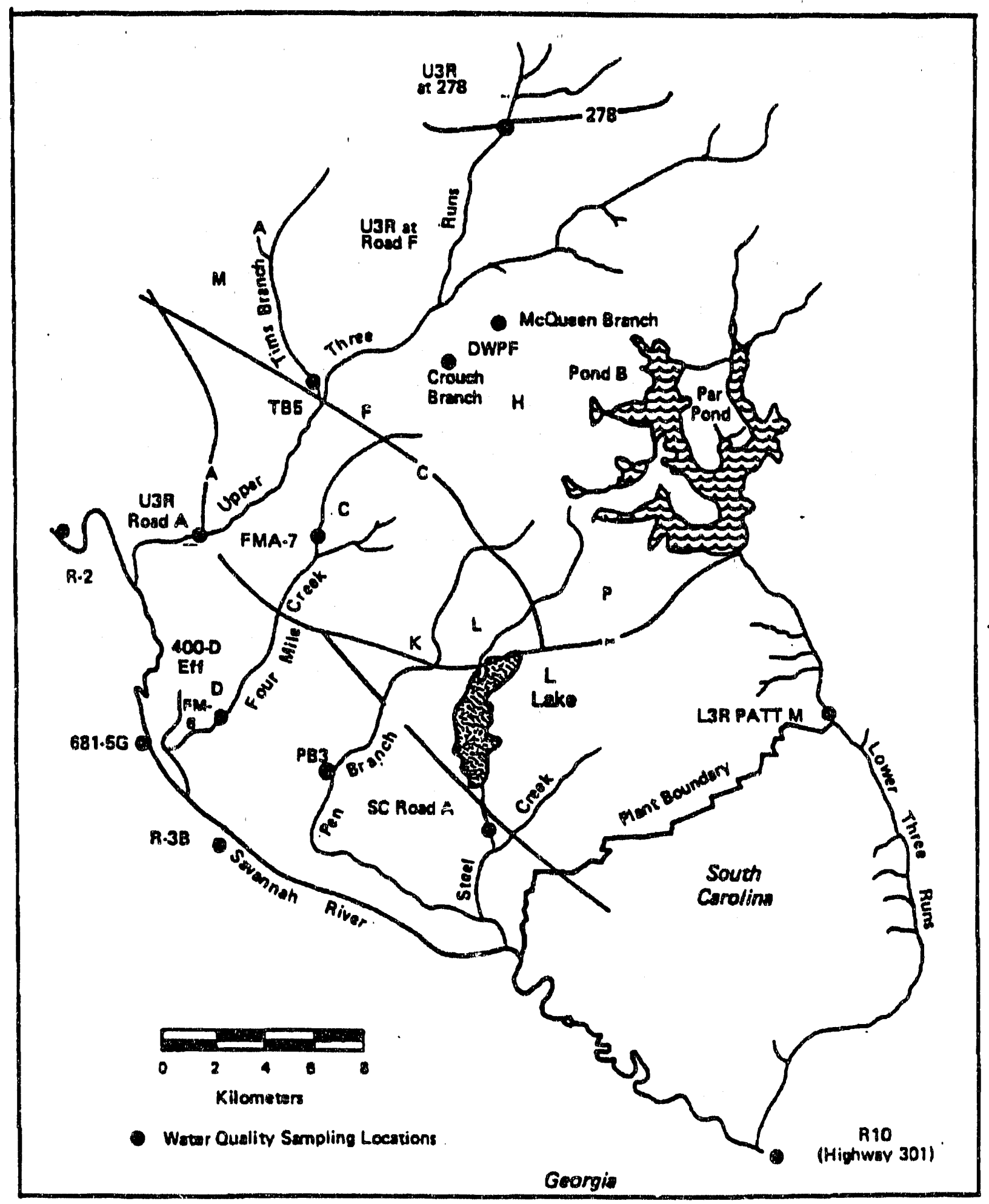

Figure A.1. Stream Location Monitored for Water Tritium Concentration 


\section{Area Effluent Outfalls}

Area effluent outfalls are routinely sampled and analyzed for tritium by Environmental Monitoring Survey Teams and analyzed by the Environmental Monitoring Group for tritium. The types of samplers utilized to collect effluent samples vary. In some locations, continuous samplers are employed that take a measured sample at a preselected time interval. These samples are usually composited over a period ranging from 1 week to 1 month. In other locations, effluents are sampled by dipping a water sample. The analysis of area effluent samples for tritium requires that the sample be diluted and a 5-mL aliquot be extracted. The aliquot is combined with $17 \mathrm{~mL}$ of Atomlight scintillation cocktail and is counted on a Beckman liquid scintillation counter for 20 min.

\section{Streams}

Streams are routinely sampled at strategic locations on the SRS. Eight streams traverse the site: (1)Tims Branch, (2) Upper Three Runs, (3) Beaver Dam Creek, (4) Four Mile Creek, (5) Indian Grave Branch, (6) Pen Branch, (7) Steel Creek, and (8) Lower Three Runs (Figure A.1). Sample collection methodologies include the employment of Brailsford pumps, paddlewheel samplers, and dip samples. Sampling frequency varies according to location and level of concern, but ranges from weekly to quarterly samples. The analysis of stream samples for tritium requires that a 5-mL aliquot of the sample be extracted and mixed with $17 \mathrm{ml}$ of Atomlight. The cocktail is then counted for 20 min on a Beckman liquid scintillation counter. Sample analysis results for tritium are compared to control samples from the Edisto River, a small river $32 \mathrm{~km}$ from the SRS with water quality characteristics similar to site streams.

\section{Savannah River}

The Savannah River receives the outflow of all the streams located on the SRS, making it the most critical sample location from the perspective of an environmental impact of site operations. The Savannah River is sampled in eight locations by continuous paddlewheel samplers. A dip sample is taken along with the padole wheel sample at location R-2. The sample locations are as follows:
R-2 Above SRS
R-3A Above Plant Vogtle
R-3B Below Plant Vogtle
R-8A Steel Creek Landing
R.8B Steel Creek Landing
R-8C Little Hell Landing
R-10 Highway 301
R-IOB Highway 301

The sampling frequencies vary from weekly, bi-weekly, to monthly depending on the location. The R-2 sample is used as a comparison for the remaining samples. The analysis of the Savannah River samples for tritium requires that the samples undergo a distillation phase to remove any radionuclides which might interfere with the measurement of the low-energy beta emission of the tritium nuclei. From the purified sample, a $5-\mathrm{mL}$ aliquot is extracted and mixed with $17 \mathrm{ml}$ of Atomlight. The cocktail is then counted twice for 150 min each. The results of the Savannah River analysis are then compared to the Edisto River control samples.

\section{Rainfall}

Rainwater samples are collected for tritium analysis from 37 locations in a $160-\mathrm{km}$ radius around the site. Nine samples are collected onsite, 14 samples at the plant perimeter, and 16 at locations within the $40-\mathrm{km}$ radius of the 


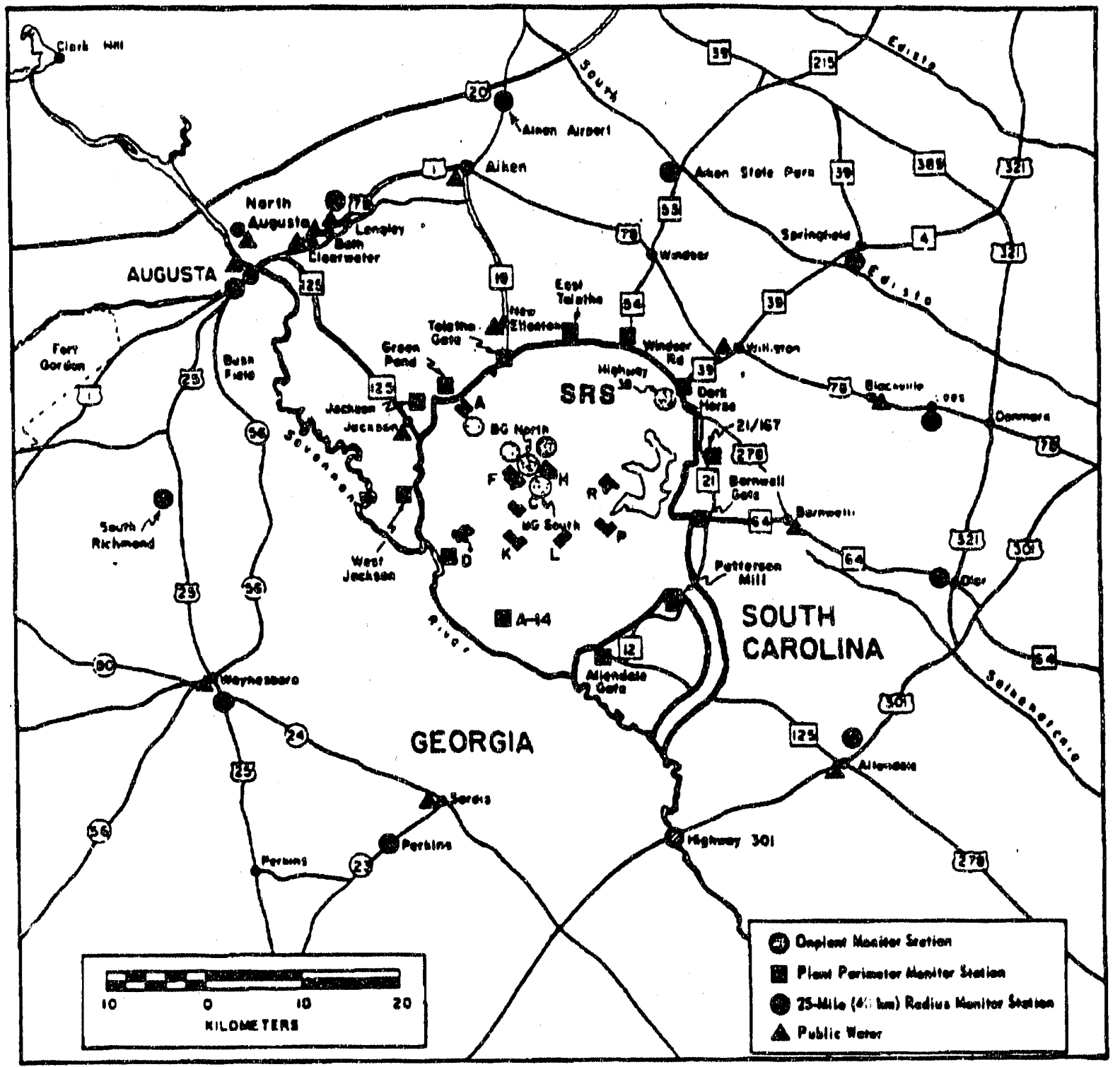

Figure A.2. Monitoring Station Locations for Measurements of Tritium in Air Moisture, Rain, and Vegetation 
plant. A sampiing station at the Environmental Monitoring Group Headquarters, near A Area is sampled once a week. All other locations are sampled biweekly, except the stations located at $160 \mathrm{~km}$, which are sampled quarterly.

The analysis of rainwater samples for tritium requires that the samples undergo a distillation phase to remove any radionuclides which might interfere with the measurement of the low-energy beta emission of the tritium nuclei. From the purified sample, a $5-\mathrm{mL}$ alquot is extracted and mixed with $17 \mathrm{~mL}$ of Atomlight scintillant. The cocktail is then counted twice for $150 \mathrm{~min}$ each.

\section{ATMOSPHERIC ENVIRONMENTAL MONITORING}

Concentrations of tritium water vapor in air are measured at eight monitoring stations on the SRS, 13 monitoring stations around the SRS perimeter, and 12 stations at distances of approximately $40 \mathrm{~km}$ from the center of the SRS (called $40-\mathrm{km}$-radius stations). The stations at the SRS perimeter and the $40-\mathrm{km}$ radius stations are arranged to permit continuous monitoring within each 30-degree sector (Figure A.2). This spacing enhances the probability of detecting a significant release of tritium from the SRS regardless of wind direction. Additional stations are monitored at a distance of approximately $160 \mathrm{~km}$.

The samplers operate continuously. Air is pumped through a silica gel column which collects the water vapor. The columns are changed once every two weeks. The water vapor is separated from the silica gel by distillation and the radioactivity of tritium in the vapor determined by liquid scintillation counting. Calculation of the air activity takes into account the volume of air sampled and absolute humidity during the sampling period. Sensitivity of the procedure is $0.3 \mathrm{pCl} / \mathrm{mL}$ of water collecterd with a counting time of $150 \mathrm{~min}$. Recovery of water is very near $100 \%$.

\section{MONITORING TRITIUM IN BIOTA}

\section{Vegetation}

Vegetation samples are collected on the general plant site and at the plant perimeter, $40-\mathrm{km}$ radius, and $160-\mathrm{km}$ radius locations. These locations are the same as those used for air monitoring. Approximately $25 \mathrm{~g}$ of sample is freeze dried, and the liquid is counted for 150 min using liquid scintillation techniques. Bermuda grass is used for the samples when available. Other plant species are utilized as necessary.

\section{Deer and Hogs}

Annual hunts are conducted at SRS to control the site deer and hog populations and to reduce animal-vehicle accidents. Selected animals are analyzed for the tritiated water activity in flesh. Approximately $30 \mathrm{~g}$ of flesh are freeze dried, and the liquid is counted as in the vegetation samples.

\section{MONITORING TRITIUM IN FOOD}

Tritium content of water in food produced in the vicinity of SRS has been measured since the early 1960s. However, before 1971 the instruments used to measure tritium could not detect the tritium in the food. Since 1971, milk and eight other types of food have been sampled and measured for tritiated water concentration.

Milk is collected from local dairies and from a distributor who collects milk from a number of local dairies. The number and 


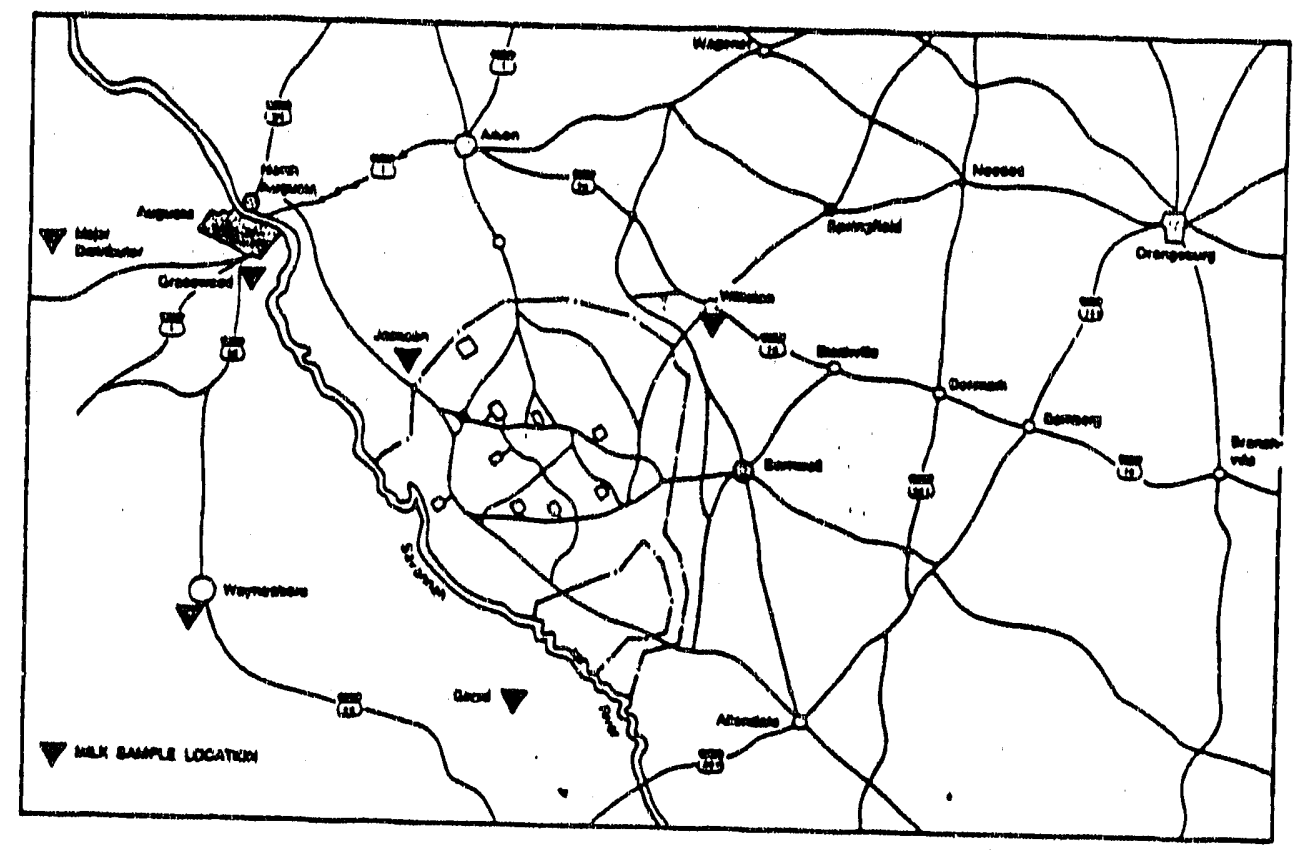

Figure A.3. Milk Collection Locations

location of the dairies varies as farmers enter and leave business. At present, samples are analyzed from six dairies and one distributor (Figure A.3). The milk is distilled and the water is collected in a cold trap. The water is mixed with a scintillant and counted on a liquid scintillation counter.

Food collections are made from local farms; often the collections are from growing crops in the field (Figure A.4). Four types of vegetable foods and an equal number of animal foods have been collected and analyzed. The animal foods include the fiesh of beef, pork, and chicken and chicken eggs. The vegetable foods include collard greens, corn, fruits (usually plums or peaches), and grain (wheat or rye). The food portion of the animal is freeze dried and the water collected in a cold trap. The water is counted on a liquid scintillation counter.

\section{TRITIUM MONITORING IN GROUND- WATER AT SRS}

The current groundwater monitoring program at SRS is a combination of several programs. The SRSEnvironmental Monitoring Section conducts both a radioactive monitoring program and a nonradioactive monitoring program. The radioactive monitoring program began in the early 1950 s and has primarily monitored for gross alpha and nonvolatile beta activities and tritium concentrations at selected sites. The samples are collected by either pumping or bailling wells, and the analyses are conducted by the Environmental Monitoring Section's laboratory and by contract 


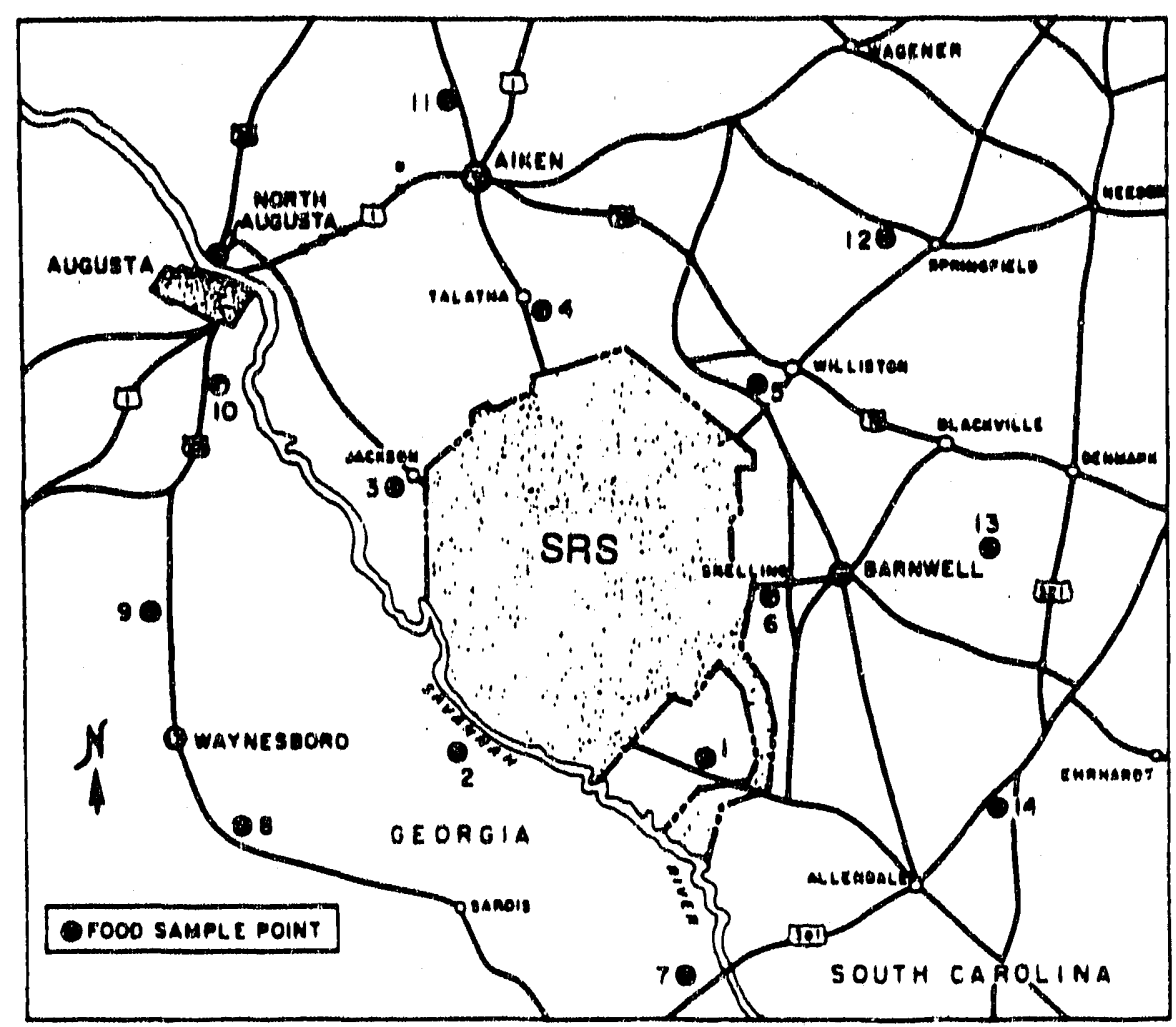

Figure A.4. Food Collection Locations for Tritiated Water Analysis

laboratories. The scope of groundwater monitoring has expanded rapidly since the nonradioactive groundwater monitoring program was established in 1982.

Two other organizations monitor the groundwater: the SRS Raw Materials Engineering and Technology Department monitors for volatile organics in $A$ and $M$ Areas, and the Interim Waste Technology Division of the Savannah River Laboratory monitors selected wells within the burial grounds. All monitoring wells are analyzed for tritium at least every 2 yr. Wells with elevated concentrations of tritium are analyzed either semiannually orquarterly. The Environmental Monitoring Section (EMS) currently monitors about 1200 wells located at all large waste sites at SRS and at many smaller waste sites or operating facilities. Analyses are generally performed by contract laboratorles. Analytical results are released quarterly in groundwater monitoring reports and annually in the Annual Environmental Report. Results are stored in a large computer data base of groundwater monitoring data. This data base can be queried to satisfy specific needs.

\section{COMPARISON OF SRS MONITORING DATA WITH SCDHEC AND GDNR}

For the past $30 \mathrm{yr}$, the concentration of tritium in the Savannah River, in surface water, and in locally produced milk supplies have been regularly monitored by the EMS at the SRS. Additionally, the South Carolina Department of Health and Environmental Control 


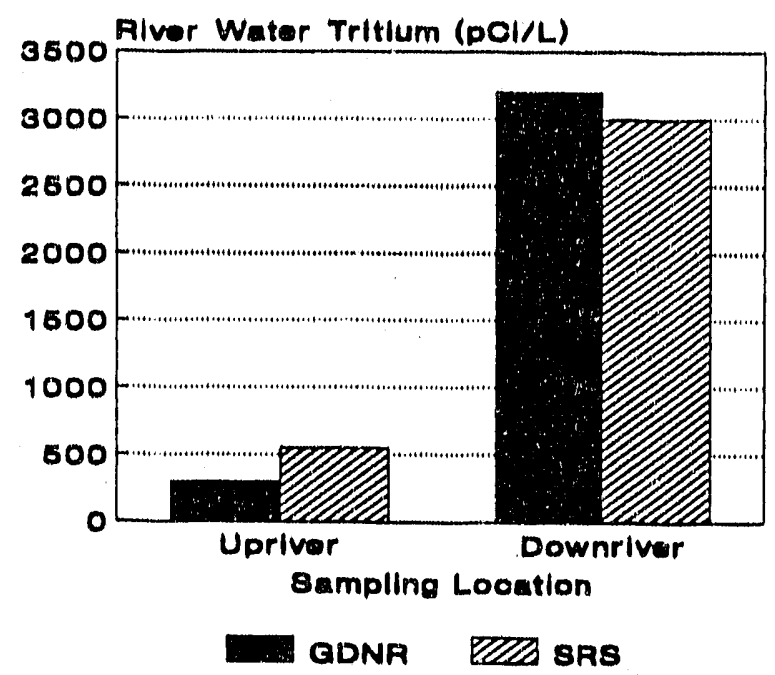

Figure A.5. Comparison of Average Tritlum Levels in the Savannah River Measured by SRS and the Georgla Department of Natural Resources from $7 / 82$ - 6/83

Department of Health and Environment Control (SCDHEC) and the Georgia Department of Natural Resources (GDNR) occasionally conduct independent surveys of tritium levels in the vicinity of the site (Du Pont 1983a, 1983b, and 1984). A comparison of the levels reported by the various groups provides an indication of the accuracy of the environmental monitoring program at the SRS.

Average tritium concentrations upriver and downriver of the SRS over a 1 yr period from July 1982 to June 1983 are given in Figure A.5. The GDNR and SRS yearly averages are in agreement to within $10 \%$. This difference may be the result of comparing yearly averages of monthly "dip" samples taken by the GDNR and yearly averages of continuous weekly samples taken by the SRS.

The average tritium concentrations shown in Figure A.5 were measured at Highway 301

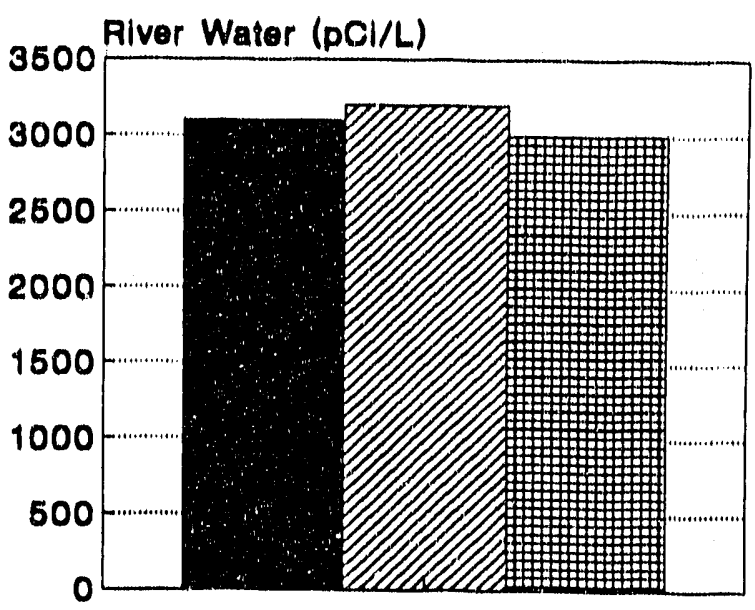

Sampling Agency

SCDHEC WIS GDNR
SRS

Figure A.6. Comparison of Tritium Concentrations in the Savannah River at Highway 301, as Measured by SRS, the Georgla Department of Natural Resources, and the South Carolina Department of Health and Environmental Control

at the Georgia/South Carolina border by all three groups during the same time period but not necessarily on the same day. Since the sampling point is the same, an unblased comparison can be made with respect to collection location. The values reported in Figure A.6 are in very good agreement, indicating a high degree of precision among testing groups.

Concentrations of tritium in water collected at the Savannah Industrial and Domestic Water Treatment Facility at Port Wentworth, GA, are reported in Figure A.7. Annual averages of the values reported by the SRS and the 


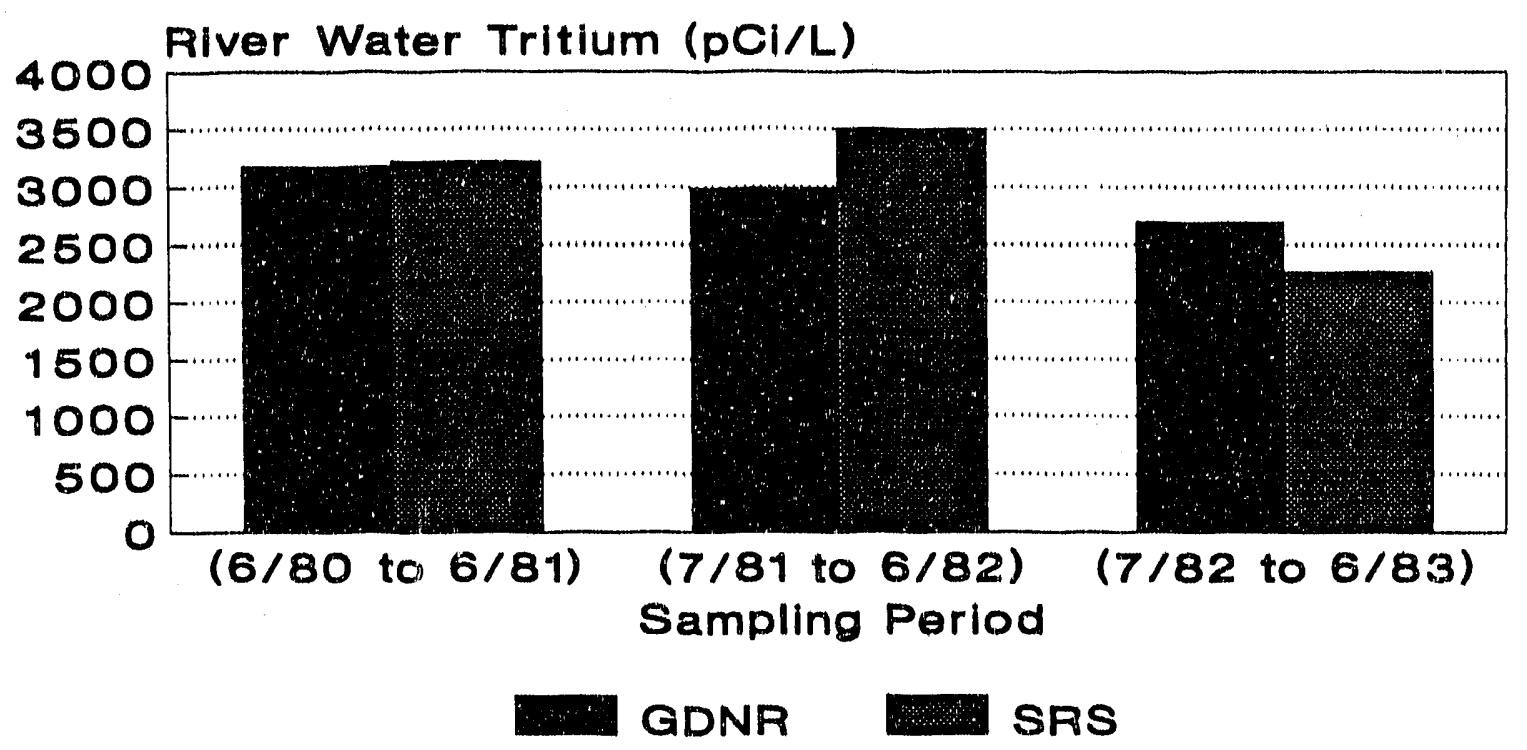

Figure A.7. Comparison of Average Tritium Levels in the Savannah River at Port Wentworth, GA, Measured by SRS and the Georgla Department of Natural Resources

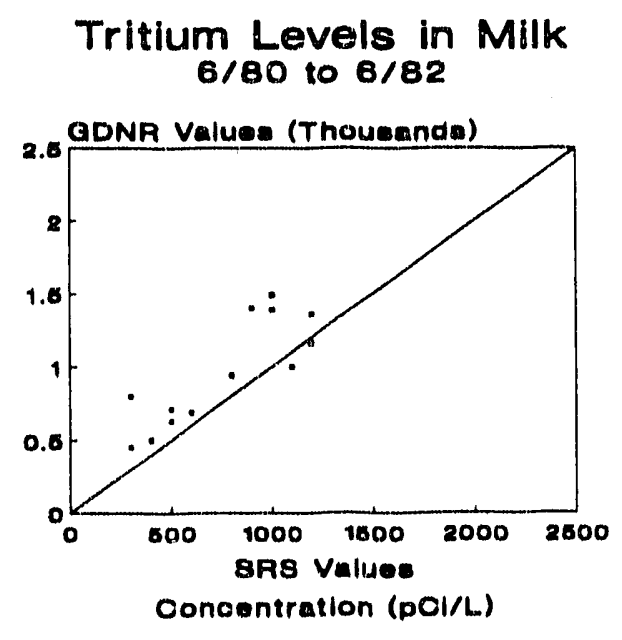

\section{Tritium Levels in Milk $7 / 82$ to $6 / 83$}

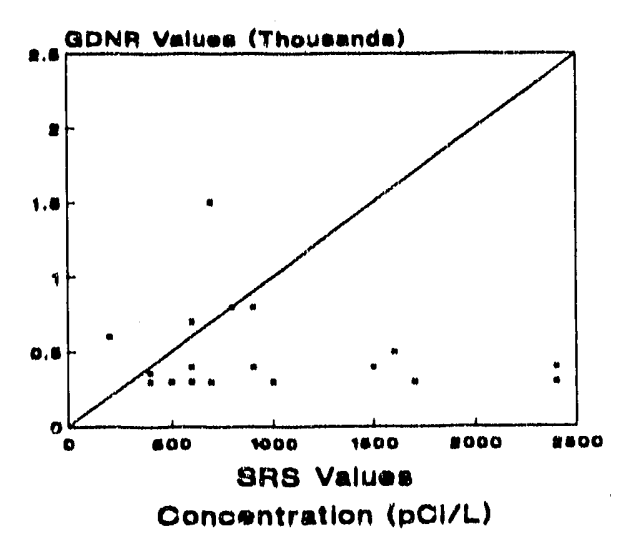

Figure A.8. Comparison of Tritium in Milk Measured by SRS and the Georgla Department of Natural Resources, 6/80$6 / 82$
Figure A.9. Comparison of Tritium in Milk Measured by SRS and the Georgia Department of Natural Resources, 7/82$6 / 83$ 
GDNR for three 1-yr periods are in good agreement. The range of values reported by the GDNR was from 1000 to $4300 \mathrm{pCl} / \mathrm{L}$ during the sampling period, while the concentration range reported by SRS was from 1200 to $3900 \mathrm{pCl} / \mathrm{L}$.

Figures $A .8$ and $A .9$ show tritium concentrations in milk collected from thrse dairies in the vicinity of SRS. The figures are for the periods of June 1980 to June 1982 and July 1982 to June 1983, respectively. The concentrations of tritium in milk determined by the SRS Environmental Monitoring Group are plotted against similar values determined by the GDNR. In this type of plot, if perfect agreement between measurements were present, all points on the plot would fall on a line passing through the origin with a slope equal to one. These lines have been drawn in the figures. The comparison of measured tritlum concentrations in milk for the time period covered by Figure $A .8$ shows that the GDNR values are systematically higher than the SRS values. However, a comparison of the concentrations obtained from July 1982 to June 1983 reveals that the SRS determinations are somewhat higher. This indicates that some systematic blas existed in both group's analysis techniques, but at different times.

\section{TRITIUM EMERGENCY RESPONSE PROGRAM}

\section{WIND System}

The SRS maintains a system of nine onsite and one offsite instrumented towers to collect real time meteorological data. Up to 125 data points are collected every $1.5 \mathrm{sec}$. In the event of a tritium release, these data would be avallable as input to the transport and dispersion codes on the WIND (Weather Information and Display) system (WSRC 1989c).
The WIND system uses real-time meteorological data, stack emission data, perimeter monitoring data, and elther a one. or two-dimensional transport and dispersion model to predict and analyze the consequences of a release. WIND provides estimates of the plume's location and centerline concentrations, which may be used to optimize the positioning of mobile sampling equipment and to provide a prellminary assessment of the threat to publio health. WIND output is avallable for examination in the Weather Center Analysis Laboratory (WCAL) and the Technical Support Center (Addis 1988).

\section{TRAC Moblle Laboratory}

Moblle monitoring capabilities for the SRS are provided by the Tracking Radloactlve Atmospheric Contaminants (TRAC) laboratory. Tritlum concentrations in air are measured by the TRAC lab using molecular sieve technology. Two types of sleves are used to support simultaneous collection of both forms of tritium (Sigg 1984). Should a major tritium release occur, WCAL personnel would dispatch the TRAC vehicle to predicted plume locations to measure tritium levels.

Tritium as water vapor ( $\mathrm{HTO}$ or $\mathrm{T}_{2} \mathrm{O}$ ) is removed from the air stream using a column containing an alumina-based material. Heat is then used to drive the trapped moisture from the column into a collection vessel. A sample of this water is discharged into a liquid scintillation cocktail for tritiurn assay by one of the two Aston liquid scintllation counters onboard the TRAC. Tritlum in the elemental form ( $\mathrm{HT}$ or $\mathrm{T}_{2}$ ) is an inert gas and therefore not effectively adsorbed on the alumina. To determine the elemental tritlum concentration, the air stream is also passed through a palladium-coated sleve. The palladium 
catalyzes the oxidation of the elemental tritlum to tritlum oxide. Any tritlum oxide generated by the presence of elemental tritium is then retained on the sieve and can be analyzed as described above.

The emergenoy response protocol establlshed for the TRAC vehlole calls for the unit to collect and analyze alr samples from nearby population centers as soon as possible after the onset of the release. Elemental and oxide tritium concentration data can be produced within 30 minutes of TRAC's arrival at a sampling location. This Information, along with plume location data, is then relayed back to the WCAL for Interpretation and communication to emergency management personnel operating from the Technical Support Center. 
TITLE

The Effect Of The Savannah River

Plant On Environmental

Radloactivity During 1959

The Effect Of The Savannah River

Plant On Environmental

Radioactivity

The Effect Of The Savannah River Plant On Environmental Radioactivity Quarterly Report January through March 1960

The Effect Of The Savannah River Plant On Environmental Radioactivity Quarterly Report April through June 1960

The Effect Of The Savannah River Plant On Environmental Radioactivity Quarterly Report July through September 1960

The Effect Of The Savannah River Plant On Environmental. Radioactivity Quarterly Report October through December 1960

The Effect Of The Savarinah River Plant On Environmental Radioactivity Quarterly Report January through March 1961

The Effect Of The Savannah River Plant On Environmental Radloactivity Quarterly Report April through June 1961

The Effect Of The Savannah River Plant On Environmental Radioactivity Quarterly Report July through September 1961
DATE

AUTHORS

Clarioe Ashley

WC Reinig

RW Van Wyok

1959

March 1961

May 1961

August 1961

December 1961 


\begin{tabular}{|c|c|c|c|}
\hline A.16 & Tritlum in the Savannah RI & Site Environn & nent \\
\hline DOC NO & TITLE & DATE & AUTHORS \\
\hline DPSPU 62-30-11 & $\begin{array}{l}\text { The Effect Of The Savannah } \\
\text { River Plant On Environmental } \\
\text { Radioactivity-Quarterly Report } \\
\text { October through December } 1961\end{array}$ & March 1962 & \\
\hline DPSPU 62-30-24 & $\begin{array}{l}\text { The Effect of The Savannah } \\
\text { River Plant On Environmental } \\
\text { Radioactivity Semiannual Report } \\
\text { January through June } 1962\end{array}$ & July 1962 & \\
\hline DPSPU 63-30-32 & $\begin{array}{l}\text { The Effect Of The Savannah } \\
\text { River Plant On Environmental } \\
\text { Radioactivity Semiannual Report } \\
\text { January through June } 1963\end{array}$ & August 1963 & \\
\hline DPSPU $64-30-2$ & $\begin{array}{l}\text { The Effect Of The Savannah } \\
\text { River Plant On Environmental } \\
\text { Radioactivity Quarterly Report } \\
\text { January through June } 1964\end{array}$ & August 1964 & C. Ashley \\
\hline DPSPU 65-30-1 & $\begin{array}{l}\text { The Efiect Of The Savannah } \\
\text { River Plant On Environmental } \\
\text { Radioactivity SemiannLial } \\
\text { Report July through } \\
\text { December } 1964\end{array}$ & February 1965 & \\
\hline DPSPU 63-30-12 & $\begin{array}{l}\text { Effect Of The Savannah } \\
\text { River Plant On Environmental } \\
\text { Radioactivity Semiannual } \\
\text { Report July through December } \\
1962\end{array}$ & January 1963 & \\
\hline DPSPU $64-30-1$ & $\begin{array}{l}\text { Effect Of The Savannah } \\
\text { River Plant On Environmental } \\
\text { Radioactivity Semiannual } \\
\text { Report July through December } \\
1963\end{array}$ & February 1964 & \\
\hline DPST $65-30-2$ & $\begin{array}{l}\text { Effect Of The Savannah } \\
\text { River Plant On Environmental } \\
\text { Radioactivity Semiannual } \\
\text { Report January through } \\
\text { june } 1 \overline{9} \overline{\overline{9}}\end{array}$ & August 1965 & \\
\hline
\end{tabular}


DOC NO

DPST 66-30-1$$
\text { DPST 66-30-1 }
$$

TITLE

Effect Of The Savannah

River-Plant On Environmental

Radioactivity Semiannual

Report July through December

1965

DPST 66-30-2

DPST $67-30-1$

DPST $67-30-2$

Effect Of The Savannah

River Plant On Environmental

Radioactivity Semiannual

Report January through

June 1966

Effect Of The Savannah

River Plant On Environmental

Radioactivity Semiannual

Report July through

December 1966

Effect Of The Savannah

River Plant On Environmental

Radioactivity Semiannual

Report January through

June 1967

DPST 68-30-1

Effect Of The Savannah

River Plant On Environmental

Radioactivity Semiannual

Report July through

December 1967

DPST 68-30-2

Effect Of The Savannah

River Plant On Environmental

Radioactivity Semiannual

Report January through

June 1968

DPST 69-30-1
Effect Of The Savannah

River Plant On Environmental

Radioactivity Semiannual

Report July through

December 1968
DATE

AUTHORS

February 1966

August 1966

February 1967

August 1967

February 1968

August 1968

March 1969 


\section{A.18 Tritium in the Savannah River Site Environment}

DOC NO

DPST 69-30-2

DPST 70-30-1

DPST 70-30-2

DPST 71-30-1

DPSPU 71-30-1

DPSPU 72-30-1

Environmental Monitoring In The Vicinity Of The Savannah River Plant Arnual Report for 1971

DPSPU 73-30-1 Environmental Monitoring In The Vicinity Of The Savannah River Plant Annual Report for 1972

DPSPU 74-30-1 Environmental Monitoring In The Vicinity Of The Savannah River Plant Annual Report For 1973

River Plant On Environmental

Radioactivity Semiannual

Report. January through

June 1971

River Plant On Environmental

River Plant On Environmental

Radioactivity Semiannual

December 1970

River Plant On Environmental

Radioactivity-Semiannual

Report. January through

Effect Of The Savannah
River Plant On Environme

Report - January through

Radloactivity Semiannual

Report. July through

June 1970
DATE

AUTHORS

August 1969

April 1970

August 1970

September 1971

\author{
March 1971
}


DOC NO

TITLE

DATE

AUTHORS

DPSPU 75-30-1 Environmental Monitoring In

The Vicinity Of The Savannah

River Plant Annual Report

For 1974

DPSPU 76-30-1 Environmental Monitoring In

The Vicinity Of The Savannah

River Plant Annual Report

For 1975

DPSPU 77-30-1 Environmental Monitoring In

The Vicinity Of The Savannah

River Plant Annual Report

For 1976

DPSPU 78-30-1 Environmental Monitoring In

The Vicinity Of The Savannah

River Plant Annual Report

For 1977

DPSPU 79-30-1 Environmental Monitoring In

The Vicinity Of The Savannah

River Plant Annual Report

For 1978

DPSPU 80-30-1 Environmental Monitoring

In The Vicinity Of The

Savannah River Plant

Annual Report for 1979

DPSPU 81-30-1 Environmental Monitoring

In The Vicinity Of The

Savannah River Plant

Annual Report for 1980

DPSPU 82-30-1 Environmental Monitoring

In The Vicinity Of The

Savannah River Plant

Annual Report for 1981

DPSPU 83-30-1 Environmental Monitoring

In The Vicinity Of The

Savannah River Plant

Annual Report for 1982 


\begin{tabular}{|c|c|c|c|}
\hline A.20 & Tritium in the Savannah Ri & Site Envirc & onment \\
\hline DOC NO & TITLE & DATE & AUTHORS \\
\hline DPSPU 84-30-1 & $\begin{array}{l}\text { Environmental Monitoring } \\
\text { In The Vicinity Of The } \\
\text { Savannah River Plant } \\
\text { Annual Report for } 1983\end{array}$ & & \\
\hline DPSPU 85-30-1 & $\begin{array}{l}\text { US Department Of Energy } \\
\text { Savannah River Plant } \\
\text { Environmental Report } \\
\text { for } 1984\end{array}$ & & \\
\hline $\begin{array}{l}\text { DPSPU } 86-30-1 \\
\text { volume } 1 \\
\text { text }\end{array}$ & $\begin{array}{l}\text { US Department of Energy } \\
\text { Savannah River Plant } \\
\text { Environmental Report } \\
\text { for } 1985\end{array}$ & & $\begin{array}{l}\text { Carroll C Zeigler } \\
\text { lbria B. Lawrimore } \\
\text { Ellen M.. Heath } \\
\text { and } \\
\text { John E. Till } \\
\text { Radiological } \\
\text { Assessments Corp. } \\
\text { Neeses, SC } 29107\end{array}$ \\
\hline $\begin{array}{l}\text { DPSPU 86-30-1 } \\
\text { volume } \|\end{array}$ & $\begin{array}{l}\text { US Department of Energy } \\
\text { Savannah River Plant } \\
\text { Environmental Repont } \\
\text { for 1985, Figures and } \\
\text { Data Tables }\end{array}$ & & $\begin{array}{l}\text { Carroll Zeigler } \\
\text { lbria B. Lawrimore } \\
\text { Ellen M. Heath }\end{array}$ \\
\hline DP-27 & $\begin{array}{l}\text { Natural Radioactive Cor tents Of } \\
\text { The Savannah River Plant }\end{array}$ & May 1, 1953 & $\begin{array}{l}\text { WC Reining } \\
\text { RE Gosline } \\
\text { EL Abenesius } \\
\text { R Williams }\end{array}$ \\
\hline HP 521 & $\begin{array}{l}\text { Savannah River Plant } \\
\text { Health Physics Department } \\
\text { Site Survey } \\
\text { Report for } 1951\end{array}$ & $\begin{array}{l}\text { August 18, } \\
1952\end{array}$ & WC Reinig \\
\hline HP 521 & $\begin{array}{l}\text { Savannah River Plant } \\
\text { Health Physics Department } \\
\text { Site Survey } \\
\text { Quarterly Report } \\
\text { January to April } 1952\end{array}$ & $\begin{array}{l}\text { June 13, } \\
1952\end{array}$ & WC Reinig \\
\hline DPSPU-54-12 & $\begin{array}{l}\text { Health Physics Site Survey } \\
\text { Data Jan to July } 1953\end{array}$ & $\begin{array}{l}\text { April 1, } \\
1954\end{array}$ & EL Abenesius \\
\hline
\end{tabular}


DOC NO

DP-92

DPSP 55-25-34

DPSP 56-25-13

Semi-Annual Progress Report Regional Monitoring Group Health Physics Section January through June 1955

DPSP 56-25-54 Health Physics Regional Monitoring Semi-Annual Report July through December 1955

DPSP 57-25-4 Health Physics Regional Monitoring Semi-Annual Report January through June 1956

DPSP $57-25-15$

Health Physics Regional Monitoring Semi-Annual Report July through December 1956

DPSP 57-25-43 Health Physics Regional Monitoring Semi-Annual Report.January through June 1957

DPSP 58-25-17 Health Physics Regional Monitoring Serni-Annual Report. July through December 1957

DPSP 58-25-38 Health Physics Regional Monitoring Semiannual Report January through June 1958
DATE

AUTHORS

November JH Horton 1954

September JH Horton 1955

April 5, 1956 JM Alexander and

JH Horton

October 26, JH Horton 1956

and

HG Mealing

February 26, JH Horton 1957

and

HG Mealing, Jr

June 27, HG Mealing, Jr 1957

November 20, HG Mealing, Jr 1957 and JH Horton

July 15, 1958 HG Mealing, Jr RS Harvey JH Horton

January 9, RS Harvey 1959 JH Horton HG Mealing 


\section{A.22 Tritium in the Savannah River Site Environment}

DOC NO

DPSPU 59-23

DPSPU 59-30

DPSPU 60-9

DPSP 60-25-26

DPSP $61-25-4$

DPSP $63-25-10$

\section{TITLE}

Health Physics Regional

Monitoring Semiannual

Report, July through

December 1958

Health Physics Regional Monitoring Semiannual

Report January through June 1959

Health Physics Regional Monitoring Semiannual

Report July through

December 1959

Health Physics Regional Monitoring Semiannual Report January through June 1960

Health Physics Regional Semiannual Report July through December 1960

Health Physics Regional Monitoring Semiannual Report January through June 1961

Health Physics Regional Monitoring Semiannual

Report July through

December 1961

Health Physics Environmental Monitoring Semiannual Report January through June 1962

Health Physics Environmental Monitoring Semiannual Report July through December 1962
DATE

August 1959

November

1959

June 1960

October 1960

October 1961

Environmental Monitoring Staff

February 1962

May 1962

February 1963

June 1963

Works Technical Department 


\begin{tabular}{|c|c|c|c|}
\hline DOC NO & TITLE & DATE & AUTHORS \\
\hline DPSPU 64-302 & $\begin{array}{l}\text { Health Physics Regional } \\
\text { Monitoring Annual } \\
\text { Report } 1963\end{array}$ & June 1964 & \\
\hline DPSPU 65-302 & $\begin{array}{l}\text { Environmental Monitoring At } \\
\text { The Savannah River Plant } \\
\text { Annual Report- } 1964\end{array}$ & June 15,1965 & C. Ashley \\
\hline DPST 66-302 & $\begin{array}{l}\text { Environmental Moritoring At } \\
\text { Savannah River Plant } \\
\text { Annual Report-1965 }\end{array}$ & August 1966 & C. Asthley \\
\hline DPST 67-302 & $\begin{array}{l}\text { Environmental Monitoring At } \\
\text { Savannah River Plant } \\
\text { Annual Report - } 1966\end{array}$ & April 1967 & C. Ashley \\
\hline DPST 68-302 & $\begin{array}{l}\text { Environmental Monitoring At } \\
\text { The Savannah River Plant } \\
\text { Annual Report - } 1967\end{array}$ & June 1968 & C. Ashley \\
\hline DPST $69-302$ & $\begin{array}{l}\text { Environmental Monitoring At } \\
\text { The Savannah River Plant } \\
\text { Annual Report - } 1968\end{array}$ & June 1969 & C. Ashley \\
\hline DPST 70-302 & $\begin{array}{l}\text { Environmental Monitoring At } \\
\text { The Savannah River Plant } \\
\text { Annual Report - } 1969\end{array}$ & May 1970 & C. Ashley \\
\hline DPST $71-302$ & $\begin{array}{l}\text { Environmental Monitoring At } \\
\text { The Savannah River Plant } \\
\text { Annual Report - } 1970\end{array}$ & June 1971 & C. Ashley \\
\hline DPSPU 72-302 & $\begin{array}{l}\text { Environmental Monitoring At } \\
\text { The Savannah River Plant } \\
\text { Annual Report - } 1971\end{array}$ & $\begin{array}{l}\text { September } \\
1972\end{array}$ & C. Ashley \\
\hline DPSPU 73-302 & $\begin{array}{l}\text { Environmental Monitoring At } \\
\text { The Savannah River Plant } \\
\text { Annual Report - } 1972\end{array}$ & August 1973 & $\begin{array}{l}\text { C. Ashley } \\
\text { C. C. Zeigler }\end{array}$ \\
\hline DPSPU 74-302 & $\begin{array}{l}\text { Environmental Monitoring At } \\
\text { The Savannah River Plant } \\
\text { Annual Report - } 1973\end{array}$ & $\begin{array}{l}\text { September } \\
1974\end{array}$ & $\begin{array}{l}\text { C. Ashley } \\
\text { C. C. Zeigler }\end{array}$ \\
\hline
\end{tabular}




\begin{tabular}{|c|c|c|c|}
\hline A.24 & Tritium in the Savannah $R$ & Site Environ & ment \\
\hline DOC NO & TITLE & DATE & AUTHORS \\
\hline DPSPU 75-302 & $\begin{array}{l}\text { Environmental Monitoring At } \\
\text { The Savannah River Plant } \\
\text { Annual Report - } 1974\end{array}$ & August 1975 & $\begin{array}{l}\text { C. Ashley } \\
\text { C. C. Zeigler }\end{array}$ \\
\hline DPSPU 76-302 & $\begin{array}{l}\text { Environmental Monitoring At } \\
\text { The Savannah River Plant } \\
\text { Annual Report - } 1975\end{array}$ & August 1976 & $\begin{array}{l}\text { C. Ashiey } \\
\text { C. C. Zeigler }\end{array}$ \\
\hline DPSPU 77-302 & $\begin{array}{l}\text { Environmental Monitoring At } \\
\text { The Savannah River Plant } \\
\text { Annual Report - } 1976\end{array}$ & March 1978 & $\begin{array}{l}\text { C. Ashley } \\
\text { C. C. Zeigler }\end{array}$ \\
\hline DPSPU 78-302 & $\begin{array}{l}\text { Environmental Monitoring At } \\
\text { The Savannah River Plant } \\
\text { Annual Report - } 1977\end{array}$ & $\begin{array}{l}\text { December } \\
1978\end{array}$ & $\begin{array}{l}\text { C. Astiley } \\
\text { C. C. Zeigler }\end{array}$ \\
\hline DPSPU 79-302 & $\begin{array}{l}\text { Envlronmental Monitoring } \\
\text { At The Savannah River } \\
\text { Plant Annual Report } 1978\end{array}$ & $\begin{array}{l}\text { January } \\
1981\end{array}$ & $\begin{array}{l}\text { C. Ashley } \\
\text { C. C. Zeigler }\end{array}$ \\
\hline DPSPU 80-302 & $\begin{array}{l}\text { Environmental Monitoring } \\
\text { At The Savannah River Plant } \\
\text { Annual Report } 1979\end{array}$ & $\begin{array}{l}\text { November } \\
1982\end{array}$ & $\begin{array}{l}\text { C. Ashley } \\
\text { C. C. Zeigler } \\
\text { P. A. Culp } \\
\text { D. L. Smith }\end{array}$ \\
\hline DPSPU $81-302$ & $\begin{array}{l}\text { Environmental Monitoring } \\
\text { At The Savannah River Plant } \\
\text { Annual Report } 1980\end{array}$ & $\begin{array}{l}\text { November } \\
1983\end{array}$ & $\begin{array}{l}\text { C. C. Zeigler } \\
\text { P. A. Culp } \\
\text { D. L. Smith }\end{array}$ \\
\hline DPSPU $82-302$ & $\begin{array}{l}\text { Environmental Monitoring } \\
\text { At The Savannah River Plant } \\
\text { Annual Report } 1981\end{array}$ & April 1984 & $\begin{array}{l}\text { C. Ashley } \\
\text { C. C. Zeigler }\end{array}$ \\
\hline DPSPU 83-302 & $\begin{array}{l}\text { Environmental Monitoring } \\
\text { At The Savannah River Plant } \\
\text { Annual Report } 1982\end{array}$ & June 1984 & $\begin{array}{l}\text { C. Ashley } \\
\text { P. C. Padezanin } \\
\text { C. C. Zeigler }\end{array}$ \\
\hline DPSPU $84-302$ & $\begin{array}{l}\text { Environmental Monitoring } \\
\text { At The Savannah River Plant } \\
\text { Annual Report } 1983\end{array}$ & June 1984 & $\begin{array}{l}\text { C. Ashley } \\
\text { P. C. Padezanin } \\
\text { C. C. Zeigler }\end{array}$ \\
\hline
\end{tabular}




\section{SRS Tritium Reports and Papers of Environmental Interest}

Albeneslus, E.L. 1959. "Tritlum as a Product of Fission," Phy. Rev. Let. 3(6): 274.

Albeneslus, E.L. and J.W. Fenimore. 1979. Tritium Migration from the Burial Ground to Four Mile Creek: Reappraisal of Flow Paths and Travel Times. DPST-79-265, Savannah River Lab., Alken, SC, 19 p.

Albeneslus, E.L. and O.A. Towler. 1983. Tritium Waste Disposal Technology in the US., DOE/CEA meeting on defense waste management, Knoxville, TN, November 1983.

Arthony, J. D. 1959. "Portable Tritium Monitor Has Gamma Compensation," Nucleonics $17(4): 110-114$.

Ashley, C., C. C. Zeigler, and D. R. Quisenberry. 1979. Tritium in the Environment at the Savannah River Plant. DPSPU 79-30-9, E.I. du Pont de Nemours \& Co., Savannah River Plant Alken, S. C

Bowman, W. and M. B. Hughes. 1981. Proportional Counting Techniques for Routine Tritium Analyses at Environmental Levels, Internation Symposium on Methods of LowLevel Counting and Spectrometry, April 6-10, 1981, West Berlin, FRG

Butler, F. E. 1963. "Determination of Tritium in Water and Urine - Liquid Scintillation Counting and Rate-of-Drift Determination." Anal. Chem. 33(3):2069-2071

Butler, H. L. and J. H. Leroy. 1963. Observations of Biological Half-Life of Tritium, DP-831 E.l. du Pont de Nernours \& Co, Inc. Aiken, SC

Butler, H. L. and J. H. Leroy. 1964. "Observations of Biological Half-Life of Tritium." Health Physics $10(8):$ : 12.
Butler, H. L. and J. H. Leroy. 1965. "Observatlons of Blological Half-Life of Tritlum." Health Phys. $11(4):$ 283-285.

Corey, J.C. and H.H. Horton. 1968. "Movement of Water Tagged with $2 \mathrm{H}, 3 \mathrm{H}$, and 180 through Acidic Kaolinitlc Soll." Soil Sci. Soc. Amer. 32(4):4.71-475

Evans, A.G., D.D. Hoel, and M.V. Kan. telo.1985. Environmental Aspects of a Tritium Release from the Savannah River Plant on March 23, 1984. DP-1695, E.l. du Pont de Nernours\& Co., Savannah River Laboratory, Alken, SC

Fallon, R. D. 1982. "Influences of pH, Temperature, and Moisture on Gaseous Tritium Uptake in Surface Soils." Appl. Envir. Microbiology 44(1) 171-178

Fallon, R. D. 1982." Molecular Tritium Uptake in Southeastern U. S. Solls." Soil Biol Biochem. 14 553-556

Fenimore, J.W. 1977. Radionuclides in 643G Ground Water, 1973-1976. DPST-77-448, E.I.du Pont de Nemours and Co., Savannah River Laboratory, Aiken, SC.

Fenimore, J.W. and J.H. Horton. 1973. Operating History and Environmental Effects of Seepage Basins in Chemical-Separations Areas of the Savannah River Plant. DPST. 72-548, E.I.du Pont de Nemours and Co., S גvannah River Laboratory, Alken, SC.

Fowler, B.F., R.V. Simmons, H.W. Bledsoe, and B.B. Looney, B.B. 1986. Savannah River Laboratory Seepage Basins: Environmental Information Document. DPST-85-688, E.I.du Pont de Nemours and Co., Savannah River Laboratory, Aikon, SC.. 


\section{A.26 Tritlum in the Savannah River Site Environment}

Garrett, A. J., C. C. Zeigler, D. R. Carver, and D. A. Stevenson. 1983. Environmental Aspects of a Tritium Release from the Savannah River Plant on July 16, 1983. DP-1672,E.I.du Pont de Nemours \& Co., Savannah River Plant, Alken, SC.

Garrett, A.J., E.L. Wilhite, and M. R. Buckner. 1981. Environmental Effects of a Tritium Release from the Savannah River Plant. DP. 1613. E. I. du Pont de Nemours \& Company, Inc., Savannah River Plant, Alken, S. C., USA

Halverson, J. E. 1981. "A statlc He-3/He-4 gas mass spectrometer for low level tritlum concentration measurements." Internation Symposium on Methods of Low-Level Counting and Spectrometry, April 6-10, 1981, West Berlln, FRG

Hawkins, R. H. 1975. "Migration of tritlum from a nuclear waste burial site." C O N F . 750967, ERDA Environmental Protection conference. U.S. Energy Research and Development Adm., Chicago, IL.

Hayes, D. W. and J. E. Hoy. 1973. "A Chromatographic System for the Enrichment and Analysis of Low Level Tritium Samples." In Tritium, (A. A. Moghissi and M. W. Carter eds.) p. 127-132, Messenger Graphics, Publishers, Phoenix, Nevada, USA

Hayes, D. W. 1974. "An Improved Electrolysis Procedure for Analyzing Tritium in Environmental Water Samples." inter. J. Appl. Radiat. Isotopes 25(11/12):573-575.

Hayes, D. W. 1976. "Tritium in the Savannah River Esturary and Adjacent Marine Waters." Conf.760628-2, American Society for Limnology and Oceanography Meeting. Savannah, Gà
Heyes, D. W. 1978. "Tritlum in the Savannah Rlver Estuary and Adjacent Marine Waters." In Behavior of Tritium in the Environment pp IAEA, Vienna

Hayes, D. W. 1982 Design and Evaluation of a Freeze-Dry Apparatus for Removing Free Water for Tritium Analysis. DP-1634, E. I. du Pont D.E. Nemours \& Co., Savannah River Laboratory, Aiken, S. C.

Hayes, D.W. 1983. Examples of Savannah River Water Dilution between the Savannah River Plant and the Beaufort-Jasper and Port Wentworth, Wa. DPST-82-1076, E. I. du Pont D.E. Nemours \& Co., Savannah River Laboratory, Alken, S. C.

Hoel, D.D. 1984. Climatology of the Savannah River Plant Site. DP-1679, E. I. du Pont de Nemours and Co., Savannah River Laboraiory, Alken, S. C.

Horton, J.H., J.C. Corey, and R.M. Wallace. 1971. "Tritlum Loss from Water Exposed to the Atmosphere." Envir. Scl. \& Tech. 5: 338-343

Horton, J.H. and R.H. Hawkins. 1965. "Flow Path of Rain from the Soll Surface to the Water Table." Soil Sci. 100(6):377-383.

Horton, J.H. and D. I. Ross. 1960. "Use of Tritlum from Spent Uranium Fuel Elements as a Groundwater Tracer." Soil Sci. 90:267-271.

Hoy, J.E.. 1961. "Operational Experience with Kanne Ionization Chambers." Health Physics 6: 203-210

Hubbard, J.E. and R.H. Emslle. 1984. Water Budget for SRP Burial Ground area.DPST83-742, E. I. du Pont D.E. Nemours and Co., Savannah River Laboratory, Aiken, S. C. 
Jacobsen, W. R.. 1975. Environmental Efrects of a Tritium Gas Release From the Savannah River Plant on December 31, 1975. DP-1415, E. I. du Pont de Nemours \& Co., Inc., Savannah River Plant, Alken,SC., USA

Jalbert, R. A. and C. E. Murphy Jr. 1988. "U.S. Team Measurements during the June 1987 Experlmental HT Release at the Chalk River Nuclear Laboratorles, Ontario, Canada," Fusion Technology 14(2):1182-1186.

Killian, T.H., N.L. Kolb, and P. Corbo, 1986. HArea Seepage Basins: Environmental information document. DPST-85-706, E. I. du Pont D.E. Nemours and Co., Savannah River Laboratory, Alken, SC.

KIng, C.M. and R. W. Root Jr. 1982. "Radlonucllde-Migration Model for Burled Waste at the Savannah Rlver Plant." Waste Manage. ment Conference, Tucson, AZ, USA, March 1982.

Kurzeja, R. J., C. E. Murphy Jr. and R. W. Taylor. 1988. "Dispersion of HT and HTO Following an Unplanned Release of Tritium to the Atmosphere." Fusion Technology 14(2):1111-1114.

Kurzeja, R.J., R.W. Taylor, J. Sharma, and L.T. Burckhalter. 1987. Environmental effects of the July 31, 1987 tritium release from the Savannah River Plant. DP-1758, E.I. du Pont de Nemours \& Co., Inc., Savannah River Laboratory, Alken,SC

Long, P.E., Jr.. 1978. Calculations for estimating the equilibrium washout of tritium. DP. 1443, E.l. du Pont de Nemours \& Co., Inc., Savannah River Laboratory, Alken, SC

Luvall, J. C. and C. E. Murphy Jr. 1982. "Evaluation of the Tritiated Wvater ivetitiod for
Measurement of Transplratlori In Young PInus taeda L." Forest Science 28 pp. 5-16

Marter, W. L. and C. M. Patterson. 1971. "Monitoring of Tritlum in Gases, Llquids, and In the Environment." Trans. Amer. Nucl, Soc. 14(1): 162-163.

Marter, W.L. 1975. Analysis of Effects of a Tritium Release from the Savannah River Plant, May 2, 1974. DP-1369, E.I. du Pont de Nemours \& Co., Savannah Rlver Laboratory, Alken, SC

Marter, W.L. and D.W. Hayes. 1982. "Deuterium and Tritlum." In: Encyclopedia of Chemical Processing and Design, Publ: Marcel Dekker, Inc.,New York, NY, 308-346 p.

Milham, A. C. and A. L. Bonl. 1976. "Detectlon and Measurement of Tritlum forms Released from a Ruclear Production Complex." Trans. Amer. Nual. Soc. 24:495-496.

Murphy, C.E. Jr. and C.W. Sweet, 1982. "Tritlum Transport around Nuclear Facllities," Proceedings of the Workshop on Tritlum Radioblology and Health Physics. National Inst. of Radlol., Matsudaira, $H, T$, Yamaguchi, T. Nakazawa, and C. Salto, (eds.) 1982. 242$261 \mathrm{p}$.

Murphy, C. E., Jr. 1989. "Controlled Environmental Estlmates of HT Uptake by Vegeta. tion." Proceedings of Third Japan-US Workshop on Tritlum Radioblology and Health Physics, Institute of Plasma Physics, Nagoya University, Nogoya, Japan

Murphy, C. E., Jr. 1986. "Modelling Tritium Transport in the Environment." Radiation Protection Do:simetry 16(1-2):51-58. 


\section{A.28 Tritlum in the Savannah River Site Environment}

Murphy, C. E., Jr., A. L. Bonl, and S. P. Tucker, 1976. The Conversion of Gaseous Molecular Tritlum to Tritlated Water in Biological Systems. DP.1422, E. l. du Pont de Ne. mours \& Co., Inc., Savannah River Laboratory, Alken, S. C.

Murphy, C. E. Jr., C. W. Sweet and R. D. Fallon. 1982. "Tritium Transport around Nuclear Facilltles." Nuclear Safety 23 677-685

Murphy, C. E. Jr., J.R. Watts, and J. C. Corey. 1977. "Environmental Tritlum Transport from Atmospherlo Release of Molecular Tritlum." Health Physics 33: 325-331

Murphy, C.E., Jr. and J.C. Corey. 1976. "Absorption of Tritlated Water Vapor from the Atmosphere by the Needles of PIne Trees." Radioecology and Energy Resources. CushIng, C.E. (ed.), 108-112

O'Kula, K.R. and W.H. Horton. 1988. "Prelimirlary Risks Associated with Postulated Tritium Release from Production Reactor Operation." Third topical meeting on tritium technology in fission, fusion and isotopic applications, Toronto, Canada, 1 May 1988.

Pekkala, R.O., C.E. Jewell, W.G. Holmes, and I.W. Marine. 1987. Environmental Information Document: Reactor Seepage Basins. DPST-85-707, E. I. du Pont D.E. Nemours and Co., Savannah River Laboratory, Alken, SC.

PIllinger, W.L. and W.L. Marter. 1982. Standardlzed Dose Factors for Dose Calculations - 1982 SRP Reactor Safety Analysis Report Tritium, lodine, and Noble Gas. DPST-82708, E. I. du Pont D.E. Nemours and Co., Savannah River Laboratory, Alken, SC..
Relchert, S. O. 1962. "Radionuclides in Grandwater at the Savannah Rlver Plant Waste Repository Facllitles." J. Geophys. Res. 67: 4363-4374.

Root, R.W. Jr. 1981. Savannah River Laboratory Dose-to-Man Model. Appendix A. Deterministic studies - SRL Model. DP-MS-81-24, E. I. du Pont D.E. Nemours \& Co., Savannah River Laboratory, Alken, S. C. 20 p.

Sanders, S.M. and W.C. Reinig. 1969. "Assessment of Tritlum in Man." Proceedings of a Symposlum held at Richland, Wash, May 15-17, 1967. Excepta Medica Foundation, Holland.

SRP. 1978-83. Environmental Monitoring in the Vicinity of the Savannah River Plant. Annual Reports (1978-83). E. I. du Pont de Nemours and Company, Inc., Savannah River Plant Alken, SC.

Watts, J. R. and C. E. Murphy Jr. 1978. "Assessment of Potential Radiation Dose to Man from an Acute Tritium Release Into a Forest Ecosystem." Helath Phys. 35(2): 287292.

Watts, J.R. 1979. "Comparison of Calculated and Measured Radlation Doses from Chronic Aqueous Releases." Health Phys. 36(4): 519521.

Woods, F.W. and D. O'Neal. 1965. "Tritlated Water as a Tool for Ecological Field Studles." Science 147: 148-149. 
Tritium is an isotope of hydrogen that was discovered in 1939 by Rutherford. The three known lsotopes of hydrogen are:

Protium - ${ }_{1} \mathrm{H}$ Stable

Deuterlum - ${ }^{2}$ H Stable

Tritlum - ${ }_{1}^{3} \mathrm{H}$ - Radloactive

Tritlum is the rarest of all known natural isotopes, occurring only one time in $10^{18}$ parts of ${ }_{1} \mathrm{H}$.

Tritlum is colorless, odorless, and tasteless and has a mass of 3.0260 mass units.

It exists as a gas or an oxide $(T, H T, H T O$, and $\mathrm{T}_{2} \mathrm{O}$ where $\mathrm{T}=$ tritlum and $\mathrm{H}=$ hydrogen)

Tritlum is formed artificially as follows:

${ }_{3}^{6} \mathrm{LI}+{ }_{0}^{1} \mathrm{n} \rightarrow{ }_{1}^{3} \mathrm{H}+{ }_{2}{ }_{2} \mathrm{He}+4.8 \mathrm{MeV}$

${ }_{1}^{2} \mathrm{H}+{ }_{0}^{1} \mathrm{n} \rightarrow{ }_{1}^{3} \mathrm{H}$

Ternary fission

The probabillty of deuterium capturing a neutron depends on the cross section measured in barns. Deuterium has a cross section of 0.00057 barns.
Tritlum is also produced naturally in the upper atmosphere from nitrogen by reactions with cosmic-ray neutrons.

${ }_{7}^{14} \mathrm{~N}+{ }_{0} \mathrm{n} \rightarrow{ }^{12} \mathrm{C}+{ }_{1}^{3} \mathrm{H}-4.3 \mathrm{MeV}$

and

${ }_{14}^{14} \mathrm{~N}+{ }_{0}{ }_{0} \mathrm{n}->3{ }_{2}{ }_{2} \mathrm{He}+{ }_{1}{ }_{1} \mathrm{H}-11.5 \mathrm{MeV}$

Tritlum emits a weak beta particle that has a maximum energy of $18.6 \mathrm{KeV}$ and an average energy of $5.7 \mathrm{KeV}$.

The physical half-llfe of tritlum is 12.35 years and the mode of decay is by the emission of a beta particle to form ${ }_{2}^{3} \mathrm{He}$.

${ }_{1}^{3} \mathrm{H} \rightarrow{ }_{2}^{3} \mathrm{He}+{ }_{\cdot 1}^{0} \theta$

Actlvity - mass relationship:

$T_{2}$ gas $-9,700$ curies/gram

2.6 curies/cc at S.T.P.

$\mathrm{T}_{2} \mathrm{O}$ llquid - 2,650 curles/gram

HTO llquid - 1,460 curles/gram

${ }_{1}^{3} \mathrm{H}$ interchanges with and replaces, $\mathrm{H}^{\prime}$ in many materials under certain temperatures and pressures. 

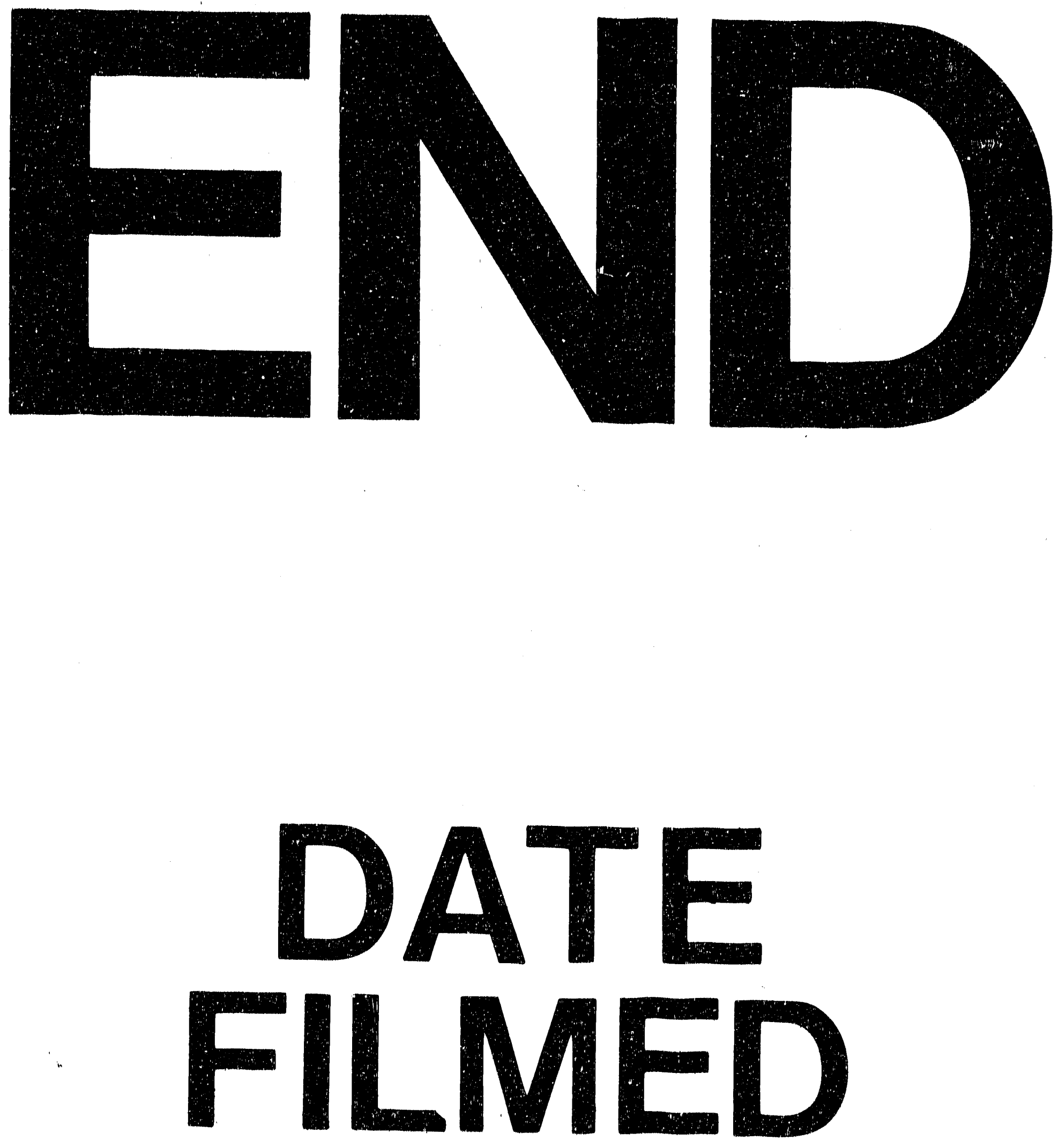

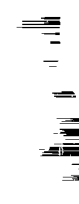

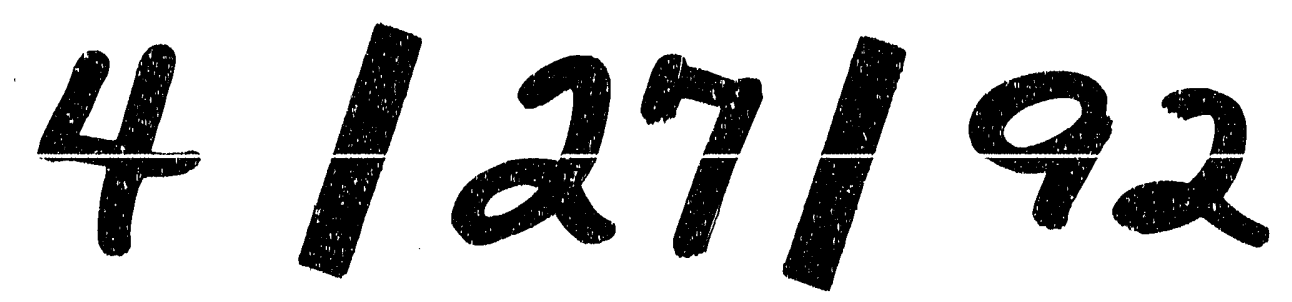

